MARCELO GIANINI

\title{
DIÁLOGO DE SURDOS:
}

reflexões acerca do ensino de Teatro na Educação Básica em Alagoas (e suas possíveis reverberações em outros contextos)

Tese de Doutorado

ESCOLA DE COMUNICAÇÕES E ARTES

UNIVERSIDADE DE SÃO PAULO

2016 


\section{MARCELO GIANINI}

\section{DIÁLOGO DE SURDOS:}

\section{reflexões acerca do ensino de Teatro na Educação Básica em Alagoas (e suas possíveis reverberações em outros contextos)}

Tese apresentada à Escola de Comunicações e Artes da Universidade de São Paulo, para a obtenção do título de Doutor em Artes.

Área de Concentração: Pedagogia do Teatro.

Orientação: Prof ${ }^{a}$. Dra ${ }^{a}$. Maria Thaís Lima Santos 
Autorizo a reprodução e divulgação total ou parcial deste trabalho, por qualquer meio convencional ou eletrônico, para fins de estudo e pesquisa, desde que citada a fonte.

Catalogação na Publicação

Serviço de Biblioteca e Documentação

Escola de Comunicações e Artes da Universidade de São Paulo Dados fornecidos pelo(a) autor(a)

Gianini, Marcelo

Diálogo de surdos:: reflexões acerca do ensino de Teatro na Educação Básica em Alagoas (e suas possíveis reverberações em outros contextos) / Marcelo Gianini. -- São Paulo: M. Gianini, 2016. $340 \mathrm{p}$.

Tese (Doutorado) - Programa de Pós-Graduação em Artes Cênicas - Escola de Comunicações e Artes / Universidade de São Paulo.

Orientadora: Maria Thaís Lima Santos

Bibliografia

1. Pedagogia do teatro 2. Educação Básica 3. PCN-Arte 4. Encenação 5. Escola I. Santos, Maria Thaís Lima II. Título.

CDD 21.ed. - 792 


\section{Termos de aprovação}

Nome do Autor: Marcelo Gianini

Título da Tese: Diálogo de surdos: reflexões acerca do ensino de Teatro na Educação Básica em Alagoas (e suas possíveis reverberações em outros contextos)

Presidente da Banca: Profa. Dra. Maria Thaís Lima Santos

Banca Examinadora:

Prof. Dr. Instituição:

Julgamento:

Assinatura:

Prof. Dr. Instituição:

Julgamento: Assinatura:

Prof. Dr. Instituição:

Julgamento: Assinatura:

Prof. Dr. Instituição:

Julgamento: Assinatura:

Prof. Dr. Instituição:

Julgamento: Assinatura:

Aprovada em: 
Um professor é alguém que ama seu tema ou matéria, que se preocupa com ela e presta atenção a ela. Ao lado do "amor pelo assunto", e talvez por causa disso, também ensina por amor ao aluno. Como um amador, o professor não é apenas versado sobre algo, também se preocupa e está ativamente envolvido nesse algo.

JAN MASSCHELEIN E MAARTEN SIMONS Em defesa da escola: uma questão pública 


\section{Agradecimentos}

À Profa. Dra. Maria Thaís Lima Santos, que me deu coragem para enfrentar o tema aqui tratado e os necessários empurrões para que eu chegasse ao final.

Aos professores Maria Lúcia Pupo e José Sérgio de Carvalho, cujas contribuições no exame de qualificação foram decisivas para o encaminhamento deste trabalho.

À professora Ingrid Koudela, minha mestra.

Aos professores Walter Matias, da UFAL, e Flávio Brayner, da UFPE, em cujas aulas comecei a conhecer o extraordinário pensamento acadêmico de um país que eu desconhecia.

Ao companheiro da aventura alagoana Ivanildo Piccoli, ombro amigo nas horas de solidão e desespero acadêmico.

Aos amigos Joaquim Gama, Vilma Campos Leite e Adélia Nicolete Abreu, companheiros de teatro e de academia.

Ao amigo Paulo Gircys, o "cara": valeu, mano! É nóis!! Tamo aí sempre!!!

À minha família teatral: Ligia Helena, Marcio Castro, Carina Prestupa, Thaís Póvoa, Victor Balaton, Jorge Pezzolo, Denise Guilherme, Rafael Cesar, Carolina Ferraresi, Leonardo Reitano, Heloísa Alvarez, Caio Lacerda e mais alguns que me puxarão as orelhas por não tê-los citado aqui.

À minha mãe, Dona Cida, e ao meu irmão mais velho, Luiz Carlos, sempre a postos para acudir este caçula.

Aos meus sogros, Luiz Francisco e Brandina Bombonatti, que me acolheram como a um filho, para quem amor não é apenas uma palavra.

E ainda a Regileno (Régis) Lima, Amanda Tavares Dias, Roberta Ninin e a todos os interlocutores que, direta ou indiretamente, participam deste trabalho. 
Aos estudantes de Teatro Licenciatura da UFAL, que me mostraram onde estava a pedra.

Para Ana Paula, Matheus, Vinícius e Bombom, que são parte de mim. 


\section{Resumo}

GIANINI, Marcelo. Diálogo de surdos: reflexões acerca do ensino de Teatro na Educação Básica em Alagoas (e suas possíveis reverberações em outros contextos). São Paulo: 2016. 340 f. Tese (Doutorado) - Escola de Comunicações e Artes, Universidade de São Paulo. São Paulo.

A pesquisa das práticas de ensino do Teatro como componente curricular da disciplina Arte, na Educação Básica de Alagoas, revelam um sensível distanciamento das propostas contidas nos Parâmetros Curriculares Nacionais voltados para a área. A partir do entendimento dos diversos sentidos da arte e da escola, procurou-se problematizar a aplicação de modalidades pedagógicas voltadas para ações formativas em teatro oriundas de ambientes socioculturais para dentro do contexto escolar sem a necessária transposição didática. Por fim, apontam-se algumas possibilidades de intervenção em vários níveis desta realidade, associando a formação artística e estética a uma perspectiva da encenação.

Palavras-chave: pedagogia teatral, educação básica, PCN-Arte, encenação, escola. 


\begin{abstract}
GIANINI, Marcelo. Dialogue of Deafs: reflections on acting teaching in Alagoas Basic Education program (and their further reverberations in other contexts). São Paulo: 2016. 340 p. Thesis (Doctorate) - Escola de Comunicações e Artes, Universidade de São Paulo. São Paulo.
\end{abstract}

The research involving acting teaching practices as a curricular component of subject Arts, in Alagoas Basic Education program, reveals a significative detachment from the proposals enclosed in the National Curricular Parameters regarding that specific area. Acknowledging the understanding of the multiple meaning of Art and school, it was intended to scrutinize the application of pedagogic modalities regarding formative actions in acting, from social and cultural environments to the school context without the necessary didactic mediation. Moreover, some possibilities of intervention were pointed out in several levels of that reality, associating the artistic and aesthetic formation to a staging perspective.

Keywords: theater pedagogy, basic education, PCN-Arte, staging, school. 


\section{Sumário}

CAMINHANDO NAS DUNAS OU A FORMAÇÃO DO PESQUISADOR. .14

1. ENTRE O REAL E O IDEAL: PROSPECÇÕES SOBRE O ENSINO DE TEATRO NA EDUCAÇÃO BÁSICA EM ALAGOAS

1.1. O Professor de Teatro: entre a formação superior e a atuação na Educação Básica

1.1.1. Professor de Teatro ou Professor de Arte: polivalência ou especialização? .30

1.1.2. Conteúdos curriculares: repetição, aleatoriedade e

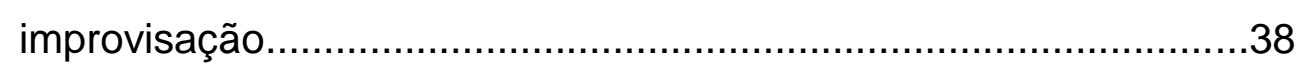

1.1.3. Paradigmas da disciplina Arte .................................................4

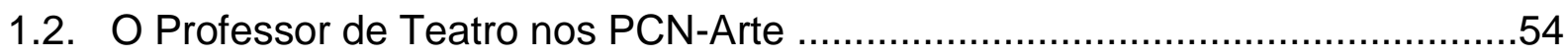

1.2.1. A concretização possível dos ideais da década de 1980: LDB e PCNArte .58

1.2.2. Da "atividade educativa" Educação Artística para a disciplina Arte. 62

1.2.2.1. Linguagens artísticas como componentes curriculares. 64

1.2.2.2. Abordagem pedagógica .66

1.2.2.3. Críticas à formação do professor polivalente .68

1.2.2.4. Questões legais e trabalhistas .70

1.2.3. Os PCN-Arte e a escola de tempo integral .76 
2.1. Arte, escola e suas diferentes formas de operar o conhecimento....................84

2.1.1. Conhecimento escolar e conhecimento da arte: fricções.......................87

2.1.2. Arte educação e "Arte Escolar": fricções...............................................95

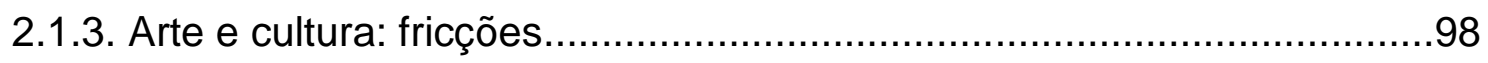

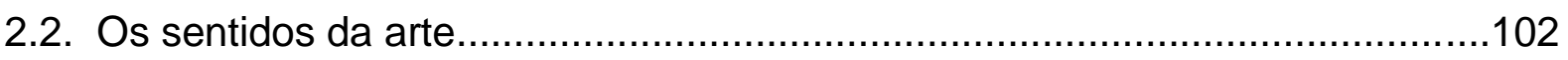

2.2.1. Quando se fala de arte, do que se está falando?...............................104

2.2.2. A estética e a poética no contexto escolar........................................107

2.3. Os sentidos da escola...........................................................................

2.3.1. Sobre a crítica às "pedagogias do aprender a aprender" .....................111

2.3.2. Sobre a crítica à pedagogia histórico-crítica.......................................120

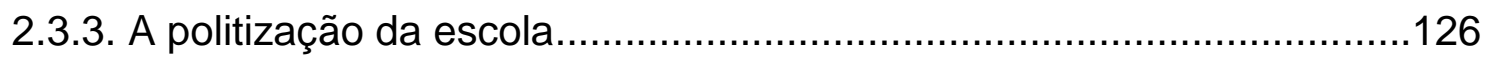

2.3.4. A escola como transição ou como tempo livre...................................130

2.4. A arte, a escola e os desafios da sociedade contemporânea.........................139

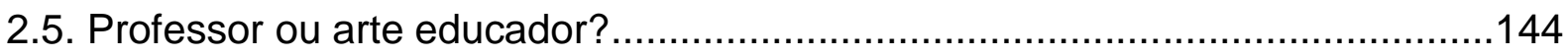

2.6. O aluno: entre o saber escolar e o saber da arte.......................................156

3. RECEPÇÃO, CRIAÇÃO E APRENDIZAGEM: A LINGUAGEM TEATRAL NA

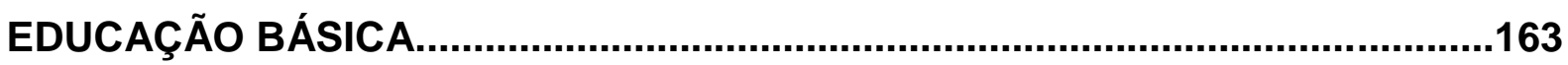

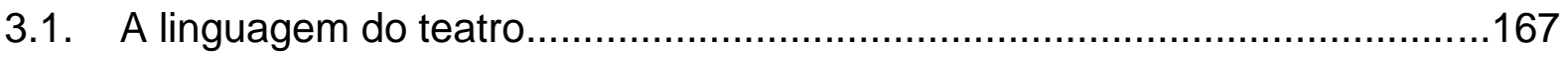

3.1.1. Pedagogias do espetáculo........................................................172

3.1.2. Pedagogias da educação dramática................................................175

3.1.3. Pedagogias do jogo improvisacional..........................................178 
3.1.4. Pedagogia do teatro: entre o ofício, a ação sociocultural e a Educação Básica

3.2. Teatro e Educação: entre a ação sociocultural e a Educação Básica 189

3.2.1. Abordagem triangular e "pedagogias do jogo improvisacional" 194

3.2.2. O jogo na educação estética e na educação poética 206

3.2.2.1. Recepção e leitura 209

3.2.2.2. $\mathrm{O}$ espectador nas "pedagogias do jogo improvisacional"

3.2.2.3. Fora do jogo: o espectador como alteridade. .222

3.3. Teatro ou linguagem teatral? 225

3.3.1. Pedagogia do Teatro e emancipação: fricções. 227

4. CONCLUSÃO EM FORMA DE PROPOSIÇÕES .233

4.1. O componente Arte na educação pública de Alagoas .235

4.1.1. Linguagem operadora e organização dos conteúdos curriculares. .237

4.1.2. Norteador espacial para o Ensino Fundamental II......................242

4.1.3. Norteador crítico-cultural para o Ensino Médio..............................246

4.1.4. A implantação dos Referenciais Curriculares alagoanos...............251

4.2. Uma proposta para o curso de Teatro Licenciatura da UFAL.........................252

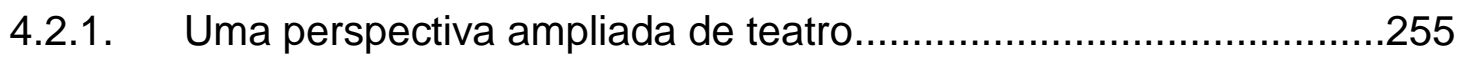

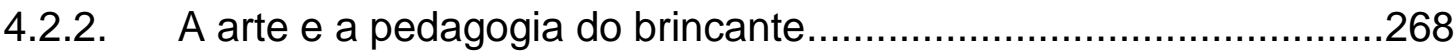

4.2.3. Práticas pedagógicas..............................................................270

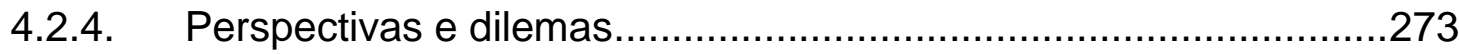


4.3. Encenação como prática pedagógica na formação do Professor de Teatro

4.3.1. Alfabetização na linguagem teatral...........................................275

4.3.2. Encenação como operador da alfabetização na linguagem

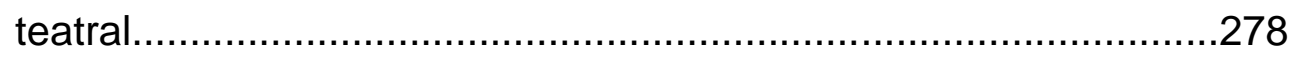

4.3.3. Encenação como ação pedagógica..............................................282

4.3.4. Uma abordagem metodológica: a encenação colaborativa..............288

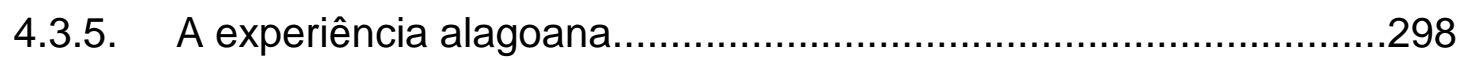

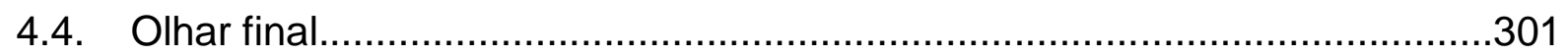

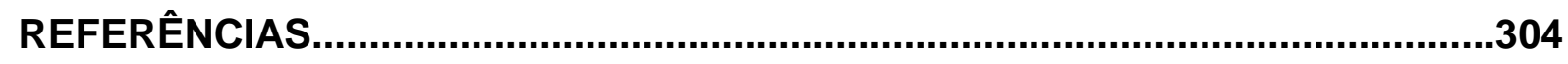

ANEXOS 


\title{
CAMINHANDO NAS DUNAS
}

\author{
ou
}

\section{A FORMAÇÃO DO PESQUISADOR}

\section{A função da arte/1}

Diego não conhecia o mar. O pai, Santiago Kovadloff, levou-o para que descobrisse o mar. Viajaram para o sul. Ele, o mar, estava do outro lado das dunas altas, esperando.

Quando o menino e o pai enfim alcançaram aquelas alturas de areia, depois de muito caminhar, o mar estava na frente de seus olhos. E foi tanta a imensidão do mar, e tanto seu fulgor, que o menino ficou mudo de beleza.

E quando finalmente conseguiu falar, tremendo, gaguejando, pediu ao pai: - Me ajuda a olhar! 
Assim me sentia na construção desta tese: como um pai que pegaria em sua mão, leitor, e o levaria para descobrir o mar. Lado a lado, caminharíamos, e você descobriria meus caminhos. Eu the mostraria as melhores veredas, os atalhos mais perigosos, a beleza das paisagens, as fontes de água. E do alto das dunas, eu the explicaria o mar. Senhor de meu mundo, que eu imaginava ser o mesmo para todos, Ihe mostraria o mesmo mar que eu já conhecia, as mesmas correntes marítimas, os mesmos corais, as mesmas marés. Tudo organizado em seu lugar, sem sustos e perfeitamente previsível, como sempre foram o mar e esse caminho para mim. Afinal, meio século de caminhadas pelo mundo já haviam me ensinado todos os caminhos, até mesmo aqueles que eu ainda não percorrera. Bastava caminhar e descobrir o que eu esperava descobrir, pois sabia o que encontraria ali e, principalmente, como explicar esses achados. O mundo tornara-se pequeno para a altura do ponto de vista que eu imaginava ter atingido e para meus instrumentos de análise. No início, foi assim.

Iniciada a caminha, fui percebendo que o caminho que eu imaginara ser firme, escapava-me sob os pés. Afinal, não pisava em terra firme, mas em areia. Dunas de areia que, assim como o rio de Heráclito, nunca são as mesmas, não conservam os caminhos já trilhados por outros. Mudam a cada pequeno vento que sopra do mar e do continente. Era preciso recriar meu próprio caminho. E o caminho era longo, muito longo, no tempo e no espaço. Percebi que o papel que me caberia nessa história não era o do pai, Santiago Kovadloff, mas sim o do filho, Diego. E que não haveria um único Santiago, sabedor do caminho, mas vários. E eu segurei forte nas várias mãos que me levavam por pequenos trechos e soltavam em outros. Mãos de mestres vistos, ouvidos e lidos, que me acompanharam até o alto das dunas. Mãos de pedagogos como aqueles escravos gregos que levavam seus pequenos senhores até a escola, onde o mundo Ihes seria aberto.

\section{FORMAR-SE PESQUISADOR}

Assim como o revolucionário dentro do elevador enlouquecido de Heiner Müller, quando a porta se abriu para que eu iniciasse a caminhada não estava mais em São Paulo, mas a quase dois mil e quinhentos quilômetros de casa, como 
docente do curso de Teatro Licenciatura da Universidade Federal de Alagoas (UFAL). O mundo girara enquanto eu estava dentro daquela máquina metálica e, ao sair, percebi que o mar que imaginava, aquele que iria redescobrir, estava mais ao sul, onde conhecia melhor as dunas, e não no norte, por entre dunas misteriosas, surpreendentes a cada pisada. No elevador/São Paulo, a tese seria sobre a encenação como metodologia de ensino do teatro; quando a porta se abriu em Alagoas, a tese começou a ser direcionada para a formação do Professor de Teatro através de processos coletivos de encenação; ao dar meu primeiro passo para fora, percebi que o caminho era mais diferente ainda do que imaginara, pois antes das dunas ainda havia um longo caminho cheio de pedras a se atravessar e que, talvez, fosse melhor retornar para o elevador, que, hoje percebo, "fora minha prisão". Mas a porta se fechara, inexoravelmente.

Caminhando por entre pedras, constatei uma grande diferença entre dar aulas de iniciação teatral em cursos e oficinas livres e participar da formação de professores. Os alunos-participantes até podem ter o mesmo desejo, o de conhecer o teatro praticando-o, mas os contextos são diferentes. Os estudantes da licenciatura participam de uma formação profissional que acontece através de muitas aulas de variadas disciplinas; seus objetivos são diversos e até mesmo contraditórios, variando entre a formação no ofício artístico e a formação na docência. Duro reconhecer que minha tese inicial, originada em contextos socioculturais, panaceia para todos os males da Humanidade, teria o mesmo destino do panglós de Brás Cubas.

O reconhecimento de que a certeza inicial não passava de uma ilusão não aconteceu como em uma epifania. Não havia revelação que pudesse ser vista por olhos fechados. Foi preciso que este pequeno Diego Kovadloff pesquisador caminhasse e derrapasse, caminhasse e caísse, até aperceber-se da ilusão. Tal revelação pode soar estranha aqui, na apresentação de uma tese acadêmica. "Melhor seria escrever um livro de auto-ajuda", pensaria o leitor mais preocupado com o rigor científico e com os finalmentes de uma tese. $O$ fato é que estas derrapadas e quedas revelaram como um pesquisador pode ser formado e, principalmente, como uma pesquisa de doutorado pode ser não a comprovação de uma tese estabelecida a priori, mas o processo de construção de um pensamento $e$ 
do próprio pesquisador. É que ao final da caminhada, lá do alto das dunas, este pequeno pesquisador descobriu no mar que ele via à distância correntes marítimas diferentes e que até então pareciam ser únicas. Dar aulas de teatro dentro do currículo escolar e fora deste requer olhares diferentes. Muitos dos companheiros de caminhada lidos durante o trajeto, antes de se chegar às dunas, pareciam afirmar o contrário: havia somente um rio submarino, uma corrente marítima. Agora, ali de cima, este pequeno pesquisador viu dois rios. Rios que se encontram em alguns trechos mas se separam em outros. Rios que talvez tenham a mesma nascente e, quem sabe, a mesma foz, mas não correm no mesmo leito. Dar aulas de teatro dentro da escola, como componente curricular de uma disciplina chamada Arte não é a mesma coisa que dar aulas extracurricularmente, ainda que dentro do contexto escolar. O mar-tese que se abrirá no primeiro capítulo irá insistentemente tocar nesta diferenciação como um ponto de vista possível. Este pesquisador afirma, já neste início, sua incerteza sobre este olhar. Ele não sabe se são mesmo duas correntes marítimas, mas irá defender esta existência dupla até o final deste escrito.

O que posso agora, nesta Apresentação, é preparar você, leitor, para as descobertas realizadas durante esta caminhada, para que talvez veja como meus olhos descobriram o mar e tentaram explicá-lo. Para que você possa, talvez, compreender porque vi certas correntes marítimas e não vi outras. E possa, ao continuar essa aventura, refazer o caminho das dunas de outra forma para que seu olhar seja outro, mais perspicaz talvez, mas outro sem dúvida nenhuma. E para que você, leitor mais experiente e experimentado em caminhos possa, talvez, vislumbrar outra forma de fazê-lo.

\section{A DESCOBERTA DA PEDRA}

No meio do caminho tinha uma pedra. Pedra-tese.

Em Alagoas, a pesquisa inicial - a formação do Professor de Teatro através da encenação - ganhou um novo recorte mas, ainda assim, mostrava-se frágil diante das prioridades e exigências do processo formativo no contexto alagoano. A realidade, mais complexa do que nosso pragmatismo acadêmico imaginava, se revelou através de relatórios de estágio e protocolos de aulas nas salas do curso de 
Teatro Licenciatura da UFAL, caminhou pelos corredores e pátio da faculdade nas palavras de angústia daqueles alunos que passavam pelas primeiras experiências no ensino formal e se corporificava no discurso dos alunos mais antigos, em forma de ironia. Próximos à conclusão do curso, os alunos afirmavam que o que eles haviam aprendido na Universidade não era o que os coordenadores pedagógicos e diretores de escolas de Educação Básica exigiam deles como conteúdo e como prática pedagógica da disciplina Arte.

Um olhar sobre o Projeto Pedagógico do Curso de Teatro Licenciatura da UFAL constatou que o mesmo estava construído de acordo com as Diretrizes Curriculares Nacionais, com o objetivo de formar professores de Teatro para atuar na Educação Básica alagoana a partir dos Parâmetros Curriculares Nacionais para o ensino de Arte (PCN-Arte), porém alguma coisa ali não estava dando certo. Ainda que o curso mostrasse diversas fragilidades na formação oferecida, o problema não parecia ser somente este, mas sim um descompasso entre o Ensino Superior e a escola formal brasileira quanto ao ensino do Teatro. Ainda que a formação do Professor de Teatro através de processos de encenação fosse um caminho interessante a ser percorrido, o problema parecia ser outro: será que a formação que se pretendia oferecer corresponderia às futuras necessidades profissionais dos estudantes de Teatro?

Lá estava a pedra. O que fazer? Ignorar o que minhas retinas registravam? Passar ao lado dela e continuar o caminho traçado ou reconhecer que a pedra exigia um desvio de caminho, por um terreno nunca percorrido por este pesquisador, ou seja, aquele que atravessa o campo da educação formal? Ao sul estava o mar que meu corpo ansiava rever. Um mar por mim estudado através de cartas náuticas, correntes marítimas, direção dos ventos. Um mar várias vezes simulado por meio de experimentos. Ali, no norte, o caminho até o mar era outro, desconhecido. Um caminho que não era só de dunas, mas também de pedras. A orientadora desta pesquisa, professora Maria Thaís Lima Santos, experiente em outras dunas, mas não nessas, observou que talvez não fosse honesto ignorar aquela pedra e que era preciso conhecer este caminho apenas vislumbrado. Talvez, quem sabe, um dia, futuros viajantes mais preparados possam se valer deste trabalho. Segurando na mão desta pedagoga, este pequeno Diego iniciou a jornada para o norte. 


\section{A DESCOBERTA DO LIVRO}

O início da caminhada pode revelar o despreparo do pesquisador em realizála e a sua falta de clareza sobre a própria pesquisa. Mas também pode revelar que as pesquisas já realizadas sobre o tema, e que poderiam servir como referências para o diálogo, parecem não ter enfrentado, ou teriam mesmo evitado a pedra encontrada. É durante o primeiro instante de perplexidade que aconteceu o encontro com a obra de Hannah Arendt.

Seu artigo "Crise na Educação" foi entendido como reacionário por este pesquisador. Ali, a autora alemã defendia o conservadorismo na educação! Como poderia ser isto? Como aceitar uma educação que procuraria conservar o conhecimento e não construir novos conhecimentos? A crença deste pequeno pesquisador sempre se dirigiu àquelas modalidades pedagógicas que se propõem à construção, afirmando que "ninguém ensina ninguém" e que o papel do professor é estimular no aluno seu próprio processo de aprendizado. Como rever uma crença que parece ter se transformado em dogma?

Havia algo no pensamento de Arendt que era preciso estudar e entender. E lá fomos nós estudá-lo e ser, a cada semana de aulas na Universidade Federal de Pernambuco, questionados e quebrados em nossas crenças educacionais. Não é que o menino Diego deixou de lado tudo o que acreditava e passou para o outro lado, fascinado e inconsequente. O que aconteceu dentro do menino foi o despertar do intelectual crítico. Não havia nenhum problema com suas crenças éticas, o problema estava em não entender que para cada contexto era preciso rever essas perspectivas críticas. Assim foi até o dia em que o professor Flávio Brayner, que conduzia os estudos sobre Arendt, proferiu uma boutade, próprias daqueles mestres que cutucam seus alunos, que provocam reações, que os faz continuar a caminhada. Disse o professor neste dia que a escola pública era o espaço privilegiado para os laboratórios e experimentos educacionais. Na escola pública brasileira testava-se de tudo, Construtivismo, Escola Nova, Educação Popular, e que o mesmo não ocorria nas escolas das elites, que seguiam o ensino tradicional tão combatido por nossos educadores mais progressistas! O estômago revirou, pois eu 
era esse educador progressista! Eu era esse cara que desprezava a educação dita tradicional em favor de uma escola nova, popular, crítica etc.

A boutade surgira em decorrência do estudo de um artigo de Arendt sobre o primeiro dia de aulas em uma escola norteamericana na cidade de Little Rock obrigada a aceitar, por lei, a presença de alunos negros. O argumento de Arendt é fulminante: o que os adultos não conseguem resolver, isto é, seu racismo, eles obrigam seus filhos a resolverem dentro da escola! Seria este o papel da escola, delegar às novas gerações a solução imediata para problemas que a sociedade não consegue enfrentar? E não seria exatamente este meu pensamento: criar uma escola e um sistema de ensino de Teatro que formasse os futuros cidadãos a agirem da forma como EU acho que seria a correta? Diz Arendt que, agindo dessa maneira, estaríamos tirando das futuras gerações a possibilidade delas próprias criarem o novo.

Neste trecho das dunas, os pés afundaram na areia, patinaram tentando sair do lugar sem sucesso. A areia mostrava-se mais fluida do que meus pensamentos. Arendt me mostrava que só conseguiria criar fissuras nos estratos se me reconhecesse como estrato, percebesse meus pensamentos como sólidos e rígidos, e criasse as fissuras primeiramente em mim mesmo. Aqui, neste trecho da caminhada, este pesquisador começou a perceber que estava entrando em um caminho diferente, perigoso, e no qual seus antigos companheiros de formação dialética não iriam segurar sua mão. Algo se rompia. Ao contrário do preceito de Heiner Müler que diz que para que algo surja é preciso que algo desapareça, o velho e o novo passaram a coabitar a mesma cabeça. Começava aqui se formar a antitese, antítese, isto é, uma contra-tese que, talvez, se voltasse contra seu próprio criador; uma anti-tese que fala de coisas que talvez ele não acredite tanto assim, mas que precisam ser ditas para que ele próprio, o pequeno pesquisador, possa voltar a suas antigas teses de maneira mais madura e crítica.

\section{A CAMINHADA}

Primeiro foi preciso estudar a pedra. 
Os Trabalhos de Conclusão de Curso e Relatórios de Estágio Supervisionado realizados pelos alunos da licenciatura em Teatro da UFAL foram os documentos analisados, nos quais se percebeu que os quinze anos de publicação dos PCN-Arte pouco haviam interferido na realidade do ensino de Arte e de Teatro na Educação Básica, em Alagoas. Se o Ensino Superior havia procurado se adaptar às novas exigências educacionais a partir da LDB de 1996 a escola formal ainda parecia estar nas décadas finais do século XX, pois exigia a polivalência do Professor de Arte. Os conteúdos de estudo das linguagens artísticas eram aleatórios e repetitivos, a disciplina Arte era confundida com o estudo das artes plásticas e as práticas pedagógicas que se apoiavam na linguagem cênica se estruturavam a partir da montagem de espetáculos. As abordagens da Arte dentro da escola formal parecem dificultar ainda mais o reconhecimento das linguagens artísticas como área de conhecimento, mantendo-as restritas a atividades de entretenimento.

A análise dos PCN-Arte nos serviu para contextualizar historicamente o que chamamos de ideal possível e para nos orientar na compreensão de seus objetivos. Esse estudo, aliado a outras legislações educacionais referentes à Arte, parece indicar um equívoco: idealizou-se o ensino da Arte e do Teatro sem levar em consideração o contexto escolar. A pedra-tese se transformou na prospecção dos problemas relacionados a esse divórcio entre o Ensino Superior, que procura formar - Professor de Teatro segundo esses ideais, e a Educação Básica, inserida na realidade alagoana.

Se no primeiro capítulo estudamos a pedra em seus aspectos mais proeminentes e visíveis - a partir dos Trabalhos de Conclusão de Curso e Relatórios de Estágio Supervisionado - no segundo capítulo analisamos as diferenças das modalidades de aprendizagem das artes e da escola. Uma questão estava aberta: seriam a escola e as pedagogias das artes projetos excludentes ou haveria alguma possibilidade de diálogo entre estas duas formas distintas de produção de conhecimento e de entendimento de mundo? O que se observou é que o próprio sentido do que seria arte e do que seria escola careciam de um mínimo de consenso. Não apenas de um lado - entre artistas e arte educadores - e do outro lado - entre gestores e comunidade escolar - mas a ausência de consenso se revela também internamente nestes grupos. Quando se fala em arte e escola parece que 
todos sabem sobre o que estão falando, mas o que se percebeu é que existem distintas formas de entendimento destes campos. A pluralidade de perspectivas produz um incontável número de análises e propostas de ação nas quais o Professor de Arte e de Teatro acaba por não conseguir estabelecer uma identidade que norteie suas ações pedagógicas. E, é claro, essa profusão de desencontros irá se refletir na formação artística e estética do aluno da Educação Básica alagoana.

Neste trecho das dunas, este pequeno pesquisador se valeu dos estudos de diversos pensadores. No caso da arte destacamos três filósofos franceses: Gilles Deleuze e Felix Guattari e suas análises sobre a forma de operar da arte, e os estudos de Jacques Rancière sobre os regimes de identificação das imagens. Quanto à escola e à educação, ao lado do pensamento de Hannah Arendt, pegaram em nossa mão outro pensador alemão, Theodor Adorno, e, principalmente, dois educadores belgas, Jan Masschelein e Maarten Simons, preciosa indicação realizada em nosso Exame de Qualificação pelo professor José Sérgio de Carvalho.

As descobertas realizadas na subida das dunas, empreendida no segundo capítulo, sobre os diversos sentidos da arte e da escola serviram como instrumentos para, do alto, olhar para o mar-tese, o ensino de teatro, e divisar a existência de diversas correntes marítimas que, por vezes, são confundidas com uma só, devido às suas similaridades e aproximações.

No terceiro capítulo, observa-se que o ensino do ofício teatral, as ações artísticas em ambientes socioculturais e o ensino do Teatro escolarizado não são a mesma coisa, ainda que se contaminem umas com as outras. Aqui surge a anti-tese, a antítese do que este pequeno pesquisador sempre defendeu, pois passou a colocar em questão as diversas modalidades pedagógicas do ensino de teatro largamente utilizadas em ações socioculturais e que, talvez, não sejam as mais adequadas para o contexto escolar se tomadas como pensamento único. A partir do estudo da abordagem triangular proposta por Ana Mae Barbosa para o ensino da Arte - que se constitui no eixo estruturante dos PCN-Arte - levantou-se a hipótese de que a articulação entre fazer, apreciar e refletir em diversas modalidades da Pedagogia do Teatro tende a secundarizar as ações de leitura da obra teatral em prol da produção ou da contextualização. O aprofundamento dos estudos de modalidades pedagógicas ligadas ao Teatro Educação, necessidade apontada no 
Exame de Qualificação pela professora Maria Lúcia Pupo, nos serviu como material de diálogo e atrito com o pensamento de Jacques Rancière acerca da emancipação intelectual.

Por fim, já descendo as dunas e entrando no mar, o quarto capítulo apresenta três proposições realizadas durante a construção desta pesquisa que talvez possam agir de maneira significativa no ensino da Arte e do Teatro como componente curricular da escola de Educação Básica: um projeto de referências curriculares para a educação pública de Alagoas, um projeto pedagógico de curso para a licenciatura em Teatro da UFAL e um olhar final para o que seria o projeto inicial de pesquisa, a encenação como prática pedagógica na formação do Professor de Teatro. Trata-se de olhares e de ações que buscam organizar o todo sob uma visão global, como é próprio da função do encenador.

Esta apresentação é um olhar panorâmico sobre o caminho trilhado. O que se segue são os estudos e as descobertas feitas a cada etapa do percurso, numa tentativa de adentrar o mar que me esperava e que agora, diante de meus olhos, se apresenta um pouco mais conhecido. Já me atrevo a entrar até os joelhos nele. Já posso apontar onde há pedras e ouriços. E peixes, belos peixes. Mas estes, dia após dia, hora após hora, mudam de lugar. Há que sempre entender a localização das pedras, verificar a presença de novos e velhos ouriços, entender a maré, a luz do sol e o sentido dos ventos para então, de novo, sairmos atrás da beleza dos peixes.

Eis o pequeno pesquisador que se fez pesquisador no caminhar. Não nasceu pesquisador, se tornou no próprio ato da pesquisa, no choque com o mundo, no embate com os materiais, no espanto, na perplexidade, na tremedeira e, muitas vezes, na gagueira. 
1

\section{ENTRE O REAL E O IDEAL: PROSPECÇÕES SOBRE O ENSINO DE TEATRO NA EDUCAÇÃO BÁSICA EM ALAGOAS}

No meio do caminho tinha uma pedra tinha uma pedra no meio do caminho tinha uma pedra no meio do caminho tinha uma pedra.

Nunca me esquecerei desse acontecimento na vida de minhas retinas tão fatigadas. Nunca me esquecerei que no meio do caminho tinha uma pedra tinha uma pedra no meio do caminho no meio do caminho tinha uma pedra. 
A tese que ora se inicia não é fruto do desejo inicial deste escriba. É uma pedra. Uma pedra encontrada no meio de um caminho que se queria suave, delineado desde o mestrado, e da qual não se pôde ignorar, nem desviar, muito menos esquecer. Inicialmente, o projeto de pesquisa se referia à sistematização da encenação como prática pedagógica, defendendo a proposição de que se pode ensinar a linguagem teatral através de uma construção coletiva da cena. A intenção era investigar e demonstrar como essa pedagogia poderia ser utilizada na formação do Professor de Teatro no ensino superior.

A pesquisa foi iniciada no curso de Teatro Licenciatura da Universidade Federal de Alagoas (UFAL), onde atuo como docente nas disciplinas relacionadas ao Teatro Educação e à Encenação, desde 2012. Trazia, até então, muitas convicções sobre qual caminho percorrer para realizar a formação de professores de Teatro e que foram, aos poucos, se transformando em questionamentos. As convicções vinham de minha experiência de mais de vinte e cinco anos em práticas formativas de iniciação teatral, realizadas em cidades da Grande São Paulo, produzindo inclusive uma dissertação de mestrado sobre 0 assunto. Os questionamentos nasceram durante o processo de elaboração deste projeto, quando passei a ser responsável pela formação de professores de Teatro neste outro estado do país, Alagoas.

Além da diferença geográfica, a nova função era, naquele momento, um paradoxo em minha vida. Mesmo sendo licenciado em Educação Artística e atuando em escolas de Educação Básica, jamais aceitei ministrar aulas dentro da matriz curricular, pois não acreditava que a aprendizagem de uma atividade artística poderia se realizar plenamente quando imposta por disciplinas que exigem avaliação sob a forma de notas e a obrigatoriedade de presença do aluno em aula. Nesta perspectiva, para se aprender teatro seriam necessários, antes de tudo, a intenção e o desejo dos participantes de se envolver em uma experiência de criação artística, características que não conseguia divisar dentro do ensino curricularizado. A transferência para Alagoas e o lugar que passei a ocupar em uma instituição que tem como objetivo formar professores para a Educação Básica me obrigaram a repensar e, principalmente, questionar essa convicção. 
Inicialmente, como docente no Ensino Superior, meus planos de cursos e aulas privilegiavam atividades voltadas à atuação do Professor de Teatro em ações socioculturais, ou seja, cursos e oficinas de formação teatral realizados fora do ensino curricularizado. A opção era consequência de minha experiência profissional e acadêmica e do ambiente artístico-pedagógico que frequentava em São Paulo, onde existe uma grande demanda por profissionais de teatro para atuar em práticas formativas que não se restringem à escola de Educação Básica. Promovidas fora do sistema educacional formal, tais atividades são realizadas sob o patrocínio de prefeituras, órgãos governamentais estaduais, entidades do terceiro setor, como as do Sistema S (SESC, SESI, SENAC) e de diversas organizações não governamentais (ONG), e até mesmo em escolas de Educação Básica que oferecem a seus alunos projetos artístico-pedagógicos extracurriculares. $O$ aumento da demanda por artistas docentes para atuar nesses espaços educativos não formais repercutiu nas licenciaturas em teatro, como afirma Maria Lúcia Pupo, ao escrever sobre a formação na Licenciatura em Artes Cênicas oferecida pela Escola de Comunicações e Artes da Universidade de São Paulo:

Se em seus primeiros tempos - lá se vão mais de três décadas - o campo da licenciatura visava exclusivamente ao ensino do teatro dentro do sistema educacional, hoje a situação é bem distinta. Demandas de entidades as mais variadas, tanto ligadas à sociedade civil como as ONGs, quanto instituições ligadas ao poder público na área da cultura como é o caso de centros culturais, além de setores da área da saúde, constituem algumas das múltiplas esferas nas quais processos de criação em teatro e, de modo mais abrangente, nas artes da cena - revelam uma área em plena expansão [PUPO, 2008, p. 55].

Isabel Marques e Fábio Brazil, em seu livro Arte em questões, também observam o mesmo movimento em relação às demais linguagens artísticas, porém como deslocamento e não expansão da área:

Notamos, [...] que, nos últimos anos, o ensino de Arte está migrando de maneira significativa para fora da escola: o ensino de Arte tem migrado ou para projetos "extracurriculares", "pós-escola", "contraturno" ou para espaços definidos por outras instituições que não sejam a escola (ONGs, fundações, associações e institutos) [MARQUES e BRAZIL, 2014, p. 74]. 
Este deslocamento da arte para projetos de ação sociocultural, às vezes no próprio ambiente escolar, causa preocupação, pois para estes autores "a arte tem perdido seu papel em projetos e propostas curriculares (dentro da escola)" (p. 75). Arão Paranaguá de Santana, ao contrário, acompanha a análise de Pupo ao observar esse movimento do ensino do Teatro como expansão e não deslocamento, que atravessou os muros da escola e "foi inserindo-se num campo que transcende à questão da escolaridade, situando-se em fronteiras que o levam à ação cultural e a outras possibilidades de desenvolvimento da consciência cidadã" (SANTANA, 2009, p. 31).

O fato é que a grande demanda por professores de Teatro para atuar em ambientes educacionais fora do ensino escolarizado faz com que a maioria dos formandos oriundos das licenciaturas em teatro e artes cênicas das universidades públicas paulistas não reconheça as escolas de Educação Básica como um campo de trabalho e de pesquisa a ser explorado. A preponderância de investigações voltadas às ações socioculturais por parte desses artistas e educadores teatrais reflete-se na pequena produção acadêmica em nível de Pós-Graduação sobre experiências de ensino da linguagem teatral dentro dos currículos escolares.

O contexto alagoano, porém, não corresponde a essa expansão ou deslocamento detectados em São Paulo, pois em Alagoas, a demanda por professores de Teatro é praticamente exclusiva das escolas de Educação Básica, ou seja, a perspectiva de trabalho dos estudantes formados no curso de Teatro Licenciatura da UFAL é restrita ao ensino escolarizado, para ministrar aulas da disciplina Arte $^{1}$. Ressalte-se que esta universidade oferece ainda as licenciaturas em Música e em Dança, sendo a única Instituição de Ensino Superior de Alagoas voltada à formação de professores de Arte no estado. Desta forma, ao se problematizar alguns aspectos relacionados à transição dos estudantes de Teatro da UFAL para as salas de aula da Educação Básica, se estará inevitavelmente

\footnotetext{
${ }^{1}$ Os termos arte e teatro, quando iniciados com minúscula, referem-se a áreas do conhecimento humano; quando iniciados com maiúsculas, referem-se à disciplina Arte e ao componente curricular Teatro, presentes nos currículos da Educação Básica do Brasil. ${ }^{1}$
} 
refletindo sobre o ensino da disciplina Arte em toda Alagoas, estado que vem apresentando há vários anos os piores resultados do país no IDEB ${ }^{2}$.

A licenciatura em Teatro da UFAL não pode ignorar este contexto social, cultural e econômico no qual está inserida. A pedra encontrada no meio do caminho não é um diamante, não é preciosa, muito menos glamorosa. É uma pedra áspera, grande e complexa que sinaliza um problema que pode ser reconhecido para além das fronteiras alagoanas. Investigar os elementos que a constituem e suas dimensões é a maneira escolhida para refletir sobre o ensino do Teatro na Educação Básica, de um modo que talvez possa ser replicado em um contexto mais amplo.

\subsection{O Professor de Teatro: entre a formação superior e a atuação na Educação} Básica

A partir da perspectiva de formador de professores de Teatro e diante de um contexto desconhecido, isto é, a inserção do ensino da Arte na Educação Básica alagoana, a investigação teve como ponto de partida a análise de documentos produzidos nos últimos cinco anos pelos estudantes do curso de Teatro Licenciatura da UFAL, em Trabalhos de Conclusão de Curso (TCC) e em Relatórios de Estágio Supervisionado. A eleição desse material de pesquisa se deve ao próprio contexto em que se dá sua produção: os estágios acontecem na segunda metade do curso e o TCC é a última atividade do estudante como licenciando. Desta forma, a análise desse material possibilita a detecção das primeiras impressões do estudante na transição entre a universidade e o contexto escolar, que se caracteriza, como se observará mais adiante, por incompreensão, dúvida e espanto dos futuros professores de Arte diante do exercício da profissão escolhida.

\footnotetext{
${ }^{2} \mathrm{O}$ Índice de Desenvolvimento da Educação Básica (IDEB), criado pelo Instituto Nacional de Estudos e Pesquisas Educacionais Anísio Teixeira (INEP), do Ministério da Educação (MEC), reúne em um só indicador dois conceitos para a qualidade da educação: fluxo escolar e médias de desempenho na avaliação. Em 2013, o estado de Alagoas não atingiu as metas estabelecidas para os anos finais do Ensino Fundamental e do Ensino Médio.
} 
Restringiu-se a análise aos documentos produzidos entre os anos de 2011 e 2014 e que possuíssem como objeto de estudo e/ou local de aprendizado a escola de Educação Básica, com o intuito de entender quais seriam as atuais dificuldades enfrentadas pelos recém-formados ao ingressarem nesse ambiente de ensino. Dos vinte e sete (27) TCC apresentados e cadastrados nos últimos quatro anos (registros acessados no Sistema Acadêmico da UFAL), dez (10) abordam o ensino da linguagem teatral na Educação Básica, sendo que, destes, oito (8) tratam de projetos extracurriculares realizados dentro das escolas e somente dois (2) têm como objeto de estudo a Arte e o Teatro como parte do currículo escolar. A falta de interesse dos licenciandos em refletir sobre o ensino do Teatro na Educação Básica em seus TCC pode ser indicativa do tamanho do problema e revela a distância entre a formação oferecida pela licenciatura em Teatro da UFAL, baseada nos Parâmetros Curriculares Nacionais: Arte (BRASIL, 1997a, 1998, 2000b), e a realidade escolar alagoana. Problema que talvez não seja exclusivo desta licenciatura, mas que pode ser comum a outros contextos, o que poderia caracterizar uma espécie de divórcio entre a universidade e a Educação Básica do país no que se refere ao ensino das artes e que se reflete nas dificuldades de implantação dos ideais possíveis presentes nos PCN-Arte dentro das escolas brasileiras.

Diante da pequena produção intelectual sobre o tema encontrada nos TCC, o que poderia falsear a pesquisa, os Relatórios de Estágio Supervisionado tornaramse o principal material de análise da situação. Quanto à amplitude deste material, é necessário registrar que das quatrocentas (400) horas de estágio supervisionado que são obrigatórias em todas as licenciaturas do país, o curso de Teatro Licenciatura da UFAL exigia que, no mínimo, cem (100) horas fossem realizadas na Educação Básica (Ensino Fundamental II, do 6ํa a ano, e Ensino Médio), em aulas da disciplina Arte. Neste contexto, foram analisados sessenta e dois (62) relatórios realizados tanto sob a perspectiva da observação, como da regência de aulas, em escolas públicas e privadas de Alagoas.

Outro material de pesquisa analisado na tentativa de compreensão desta realidade foi a dissertação de mestrado do artista teatral e arte educador alagoano Regileno Luiz de Souza Lima, Arte-Educação em questão: a (in)visibilidade dos arteeducadores licenciados em teatro nas escolas do ensino fundamental de Maceió 
(LIMA, 2012). Trata-se de investigação sobre a atuação dos professores de Teatro na Educação Básica realizada através da análise de documentos oficiais e de entrevistas com professores de Arte e gestores de cinco escolas particulares da cidade de Maceió, com atuação nunca inferior a quarenta (40) anos na capital alagoana.

A leitura dessas três fontes documentais revelou alguns aspectos da escolarização da arte e do teatro em Alagoas vistos como problemáticos por divergirem de indicações presentes nos PCN-Arte, ou por ainda carecerem de estudos específicos. Optou-se por abordar os problemas comuns e recorrentes presentes na maioria dos documentos, apresentando-os em três grandes blocos temáticos: a atuação polivalente do Professor de Teatro na disciplina Arte, os conteúdos curriculares dessa disciplina e os paradigmas que norteiam o ensino escolar das artes em geral e das artes cênicas em particular.

\subsubsection{Professor de Teatro ou Professor de Arte: polivalência ou especialização?}

Fiquei satisfeito em fazer parte e de fato trabalhar o que realmente aprendi no Curso de Teatro. Pois, quando formado o aluno de Artes Cênicas - Licenciado em Teatro, não lecionará Teatro em si, este será Professor de Artes/Teatro ${ }^{3}$ [Relatório de Estágio].

O trecho acima faz parte da avaliação do Estágio Supervisionado realizado por um estudante de Teatro Licenciatura da UFAL. A satisfação mencionada se deve à sua participação na encenação de uma peça teatral apresentada próxima ao Natal pelos alunos da escola onde realizou o referido estágio. O texto revela um dos

\footnotetext{
${ }^{3}$ Em todas as citações de TCC e de Relatórios de Estágio Supervisionado serão mantidas as formas gramaticais presentes nos documentos originais, ainda que incorretas segundo a norma culta, excetuando-se aquelas que julgar serem claramente erros de digitação.

${ }^{4}$ Em todas as citações de Relatórios de Estágio Supervisionado serão omitidos os nomes das escolas, dos professores e dos autores, por se tratar de documentos restritos às atividades curriculares do curso de Teatro Licenciatura da UFAL, não se configurando como documentos de acesso público.
} 
problemas enfrentados na transição entre a formação recebida na Universidade, de Professor de Teatro, e a real função que será exercida na Educação Básica de Alagoas, como Professor de Arte.

Nesta transição, uma reclamação recorrente dos estudantes de Teatro da UFAL que passam por suas primeiras experiências dentro de salas de aula no ensino formal, como monitores, estagiários e bolsistas do PIBID (Programa Institucional de Bolsas de Iniciação à Docência, do Ministério da Educação) é a de que a formação recebida na licenciatura não corresponde às necessidades dos professores de Arte. Quando os estágios são realizados fora da Educação Básica ou em atividades extracurriculares esta reclamação em geral não ocorre, o que nos parece revelar que o problema se localiza entre o Ensino Superior e a Educação Básica, e não na formação do Professor de Teatro para atuar em outros espaços formativos.

Poder-se-ia supor que as deficiências de formação estariam relacionadas ao exercício profissional dentro da escola formal e ao provável desconhecimento deste campo de trabalho por parte dos estudantes de Teatro. Parece não ser o caso, pois a Matriz Curricular do curso de Teatro Licenciatura da UFAL caracteriza-se pela forte presença de disciplinas voltadas à formação do docente para atuar na educação escolar, que integram o chamado Tronco Comum das Licenciaturas ${ }^{5}$ desta universidade. A presença destas disciplinas é bem avaliada pelos licenciandos e são consideradas extremamente necessárias para a formação do professor que atuará na Educação Básica. A queixa dos estudantes está relacionada às especificidades de formação do futuro professor da disciplina Arte, como se pode entender no relato citado acima.

Em Alagoas, assim como na maior parte do país, a indicação para a contratação de professores especializados nas quatro linguagens presente nos PCN-Arte (BRASIL, 1997b, 1998, 2000b), Música, Dança, Teatro e Artes Visuais,

\footnotetext{
${ }^{5}$ Seis (6) disciplinas integram o Tronco Comum das Licenciaturas da UFAL: Profissão Docente, Desenvolvimento e Aprendizagem, Planejamento, Currículo e Avaliação da Aprendizagem, Política e Organização da Educação Básica no Brasil, Projeto Pedagógico, Organização e Gestão do Trabalho Escolar e LIBRAS.
} 
não é cumprida pelas escolas e pela rede pública. Desta forma, o futuro Professor de Teatro, mesmo sem a formação adequada para ministrar aulas de outros componentes curriculares obrigatórios por $l e i^{6}$, terá que fazê-lo, o que provoca uma série de contradições entre a formação recebida e o campo de trabalho.

No Relatório de Estágio citado, o licenciando demonstra ter ciência de que sua formação voltada à linguagem teatral não será suficiente para sua atuação profissional como Professor de Arte. O que podemos apreender é que a Universidade está formando um profissional especialista para atuar na Educação Básica, mas não existe na estrutura da escola espaço curricular para tal especialização. Esta situação ocorre no estado de Alagoas e também em outras localidades do país que não contemplam o Teatro e as demais linguagens artísticas como disciplinas, mas como componentes curriculares de Arte. A ausência de espaços significativos para a linguagem teatral no currículo da Educação Básica provoca nos jovens professores de Teatro uma sensação de não pertencimento àquele universo educacional, o que, talvez, explique a satisfação descrita pelo estagiário "em fazer parte" excepcionalmente de um trabalho.

Se nas últimas décadas a universidade brasileira criou mecanismos para suprir a demanda por professores especializados, conforme indicavam os PCN-Arte, abrindo novos cursos de licenciaturas em Teatro, Dança, Música e Artes Visuais, o sistema da Educação Básica parece que ainda não realizou a transição entre a "atividade educativa" nomeada genericamente de Educação Artística para a nova disciplina obrigatória Arte. Na prática, a maioria das escolas do país, bem como as secretarias municipais e estaduais de educação, parece ter simplesmente trocado a denominação "Educação Artística" por "Arte", mas continua até hoje oferecendo os mesmos espaços em suas matrizes curriculares, sem preocupação com os diferentes enfoques que regem os atuais PCN-Arte.

\footnotetext{
${ }^{6}$ Como exemplo dessa situação, pode-se citar a Lei Federal ํㅜ 11.769, de 2008, que transformou o ensino da Música em componente curricular obrigatório na Educação Básica. A mesma obrigatoriedade se estende às demais linguagens artísticas contempladas nos PCN-Arte, Teatro, Dança e Artes Visuais, de acordo com o Projeto de Lei no 7.032, de 2010, recentemente aprovado no Congresso Nacional.
} 
A antiga formação em Educação Artística, criada pela LDB (Lei de Diretrizes e Bases da Educação Nacional, ํo 5.692) de 1971, visava o ensino das artes realizado através de aulas ministradas por um professor generalista, ou seja, um educador que transitava entre as linguagens artísticas, e que, por esse motivo, passou a ser chamado de professor polivalente. Uma das bandeiras de luta dos movimentos dos arte educadores da década de 1980 foi o fim dessa polivalência (SANTANA, 2009; JAPIASSU, 2010), o que se esperava seria concretizado com os PCN-Arte. Mais de quinze anos depois de sua implantação, esse sonho ainda não foi realizado, como revela o relato de estágio feito por um aluno de Teatro:

Em 18 de dezembro de 2012 começa minha regência de aulas na escola sob o olhar atento da professora T.L. [...]. O tema sugerido pela professora foi a importância da textura feita com fios, tiras de papel e com tintas [Relatório de Estágio].

Como um estudante de teatro pode ministrar essa aula se não possui formação em artes visuais? Pode-se argumentar que em uma licenciatura em Teatro os estudantes recebam noções das artes plásticas presentes em disciplinas voltadas à cenografia, indumentária, iluminação e maquiagem, mas não se pode dizer o mesmo, por exemplo, de uma licenciatura em Música. O divórcio entre as licenciaturas em Arte e a Educação Básica parece vir de uma incompatibilidade de gênios revelada na aversão daquelas em formar os professores polivalentes necessários a esta, e na recusa desta em criar as condições necessárias para o exercício profissional de professores especialistas.

Rosyer Souza Silva (2014), em seu TCC A importância do ensino das Artes nos colégios particulares, descreve uma série de exemplos que explicitam este divórcio e as maneiras como procurou enfrentar o problema. $\mathrm{O}$ trabalho foi realizado a partir da descrição e análise de processos pedagógicos desenvolvidos pela licencianda em uma escola particular da cidade de Maceió, na condição de professora responsável pela disciplina Arte, no Ensino Médio. Note-se que ela ainda não possuía o diploma da licenciatura e, ainda assim, exercia a profissão em uma instituição de ensino, revelando outro problema de âmbito trabalhista que será tratado mais a frente. Segundo seu relato cada um dos bimestres foi dedicado a uma das quatro linguagens artísticas indicadas nos PCN-Arte, em uma abordagem pedagógica incomum nos documentos analisados, pois o que prevalece nos planos 
de curso e de aula apresentados nos Relatórios de Estágio é a ausência da maioria das linguagens artísticas. Rosyer Silva, ao contrário, além do desejo de contemplar as quatro linguagens artísticas em suas aulas, tenta estabelecer critérios próprios diante da ausência de recursos:

Ao relatar as minhas experiências vou conceituar a Dança, como eu vejo para mim o ensino dessa disciplina. Então é uma forma de uma terapia, onde as pessoas se sentem bem ao fazê-la. É através da dança que se encontra alguns movimentos do nosso corpo que um dia deixou de se mover. Conclusão a dança faz parte da nossa vida e que é a alma do nosso corpo [SILVA, 2014, p. 35].

Nota-se o desconhecimento da dança como linguagem, isto é, como "capacidade humana de articular significados coletivos em sistemas arbitrários de representação" (BRASIL, 2000a, p. 05), tal como os PCN para o Ensino Médio conceituam linguagem. O desconhecimento da dança como "sistema arbitrário de representação", e que seria, portanto, produtora de sentidos, pode ser consequência de várias deficiências na formação da autora, que se refletem não somente no nível de elaboração de seu pensamento, como também na ausência de paradigmas para o reconhecimento da Dança como linguagem. Deficiências talvez decorrentes da formação recebida em sua licenciatura de origem, na qual não só se "produziu" tal reflexão, como também a avalizou, ao permitir que a mesma integre um Trabalho de Conclusão de Curso. Mas, no caso, culpar somente a instituição e/ou a jovem professora pode mascarar outras deficiências que vão desde uma visão de Arte que permite conceituações a partir de "achismos" e do que se sente e se vê, até uma permissividade desta área de conhecimento que não encontra correspondência em outras áreas do conhecimento escolar.

Os PCN-Arte para o Ensino Médio, ao tratarem do campo da recepção, reconhecem

a necessidade de uma reflexão acerca da própria atitude crítica e analítica, concomitantemente ao processo de apreciação. No plano da crítica, é o que distingue o "achismo" da interpretação ou da emissão de juízos amparados em critérios sólidos e coerentes com o próprio objeto submetido à fruição, apreciação e análise [BRASIL, 2000b, p. 52]. 
O fato é que a ausência de "critérios sólidos e coerentes com o próprio objeto" pela Professora de Arte citada em relação às linguagens artísticas que não fazem parte de sua formação, continua sendo predominante na escola formal. Ainda que a conceituação de dança apresentada acima possa ser um exemplo extremo de deformações ignoradas pelo Ensino Superior, estas são reproduzidas por alunos, professores de outras áreas e gestores da Educação Básica, propagando o estigma que as artes enfrentam dentro das escolas, onde ainda não se legitimaram como área de conhecimento. Há mais de quinze anos, os PCN-Arte já colocavam essa questão:

O que se observa, então, é uma espécie de círculo vicioso no qual um sistema extremamente precário de formação reforça o espaço pouco definido da área com relação às outras disciplinas do currículo escolar. Sem uma consciência clara de sua função e sem uma fundamentação consistente de Arte como área de conhecimento com conteúdos específicos, os professores não conseguem formular um quadro de referências conceituais e metodológicas para alicerçar sua ação pedagógica [BRASIL, 1998, p. 26].

O que os PCN-Arte denunciam como "um sistema extremamente precário de formação" não pode ser creditado somente às universidades, pois a ausência de uma "fundamentação consistente de Arte como área de conhecimento" deve-se também ao que foi chamado de divórcio entre a Educação Básica e o Ensino Superior. Criou-se uma espécie de profissional esquizofrênico, que recebe uma formação específica e especializada sabendo-se de antemão que esta não corresponderá às exigências e condições encontradas no local onde esse profissional irá atuar, ou seja, o Estado forma profissionais para atuar na Educação Básica, mas a formação oferecida não corresponde às atividades fins, que o próprio Estado designou.

Como se ter uma "consciência clara de sua função" para "formular um quadro de referências conceituais e metodológicas" se o próprio sistema educacional do país, no que se refere à formação e a atuação do Professor de Arte, carece de clareza? O que podemos observar é que a formação especializada para um contexto educacional no qual ainda prevalece a polivalência é parte da precariedade na formação denunciada pelos próprios PCN-Arte. 
Edilene Barbosa da Silva (2013), em seu TCC Reflexões sobre o ensino do teatro, aborda em diversas passagens de sua monografia a questão da polivalência, ora tentando entendê-la, ora procurando nela soluções para uma prática pedagógica: "Agora temos o professor de teatro que está como professor de artes (dança, artes visuais, música). Como trabalhar várias linguagens que não são sua especialidade?" (SILVA, 2013, p. 30). É reveladora a escolha do verbo "está como professor de artes" para designar a função do Professor de Teatro na Educação Básica em lugar de "é professor de artes" e que pode ser esclarecida na sequência do texto, quando a autora associa o segundo verbo, ser, à especialização em uma linguagem artística. Assim, a aluna reconhece que a formação específica qualificaria o profissional em sua essência, ser, enquanto o exercício da polivalência o qualificaria em seu estado, estar.

Afinal, por vezes, o professor de uma das quatro linguagens artísticas é responsável por ministrar todas as linguagens, uma prática que está distante da sua formação. Há, no ambiente educacional, a procura de um profissional multiuso, como se o ensino dessas linguagens fosse passiva a qualquer profissional. Em nossa mente ficam as seguintes indagações, isso acontece porque é mais fácil pagar um profissional ao invés de quatro ou é simplesmente a ignorância no que diz respeito à arte? [p. 27].

Edilene Silva não se reconhece como Professora de Arte, mas sim como Professora de Teatro; mostrando-se satisfeita com sua formação específica, duvida que possa ministrar aulas de outra linguagem que esteja "distante de sua formação". O adjetivo que escolhe para designar o professor polivalente é contundente: "profissional multiuso", ou seja, um profissional "passivo", que pode ser "usado" pela instituição e pelo sistema educacional para ministrar aulas de linguagens artísticas para as quais não recebeu formação. Essa ótica insere o problema também na área trabalhista ao se referir à economia que se faria com a contratação de apenas "um profissional ao invés de quatro" como uma das dificuldades encontradas pelas artes em se legitimarem como área de conhecimento no ambiente escolar. Com a intenção de encontrar soluções, Edilene Silva faz uma proposição:

É indispensável falar sobre as outras linguagens, considerar a importância delas na vida dos alunos e na sociedade, mostrar respeito ao citá-las em suas aulas, interesse ao realizar alguma atividade [...]. É conveniente ao professor de teatro usar da prática teatral para oferecer aos alunos as atividades voltadas a outras linguagens artísticas, a ele cabe simplesmente a interdisciplinaridade [p. 31]. 
A autora propõe perspectiva semelhante a assumida por Rosyer Silva (2014), na monografia citada anteriormente, para o Professor de Teatro que está Professor de Arte, ou seja, a inevitável necessidade de se abordar as quatro linguagens artísticas nas aulas e nos planos de curso. Porém, se Rosyer Silva propõe o estudo de uma linguagem por bimestre letivo, Edilene Silva sugere a "prática teatral", linguagem de sua especialização, como operador para realizar o que ela chama de "interdisciplinaridade" entre as linguagens artísticas. A proposição nos parece uma solução possível para enfrentar o problema da polivalência por parte dos professores de Arte especializados na linguagem teatral. E o teatro, por se caracterizar como uma linguagem que se utiliza de elementos cênicos, visuais e sonoros para criar e dar sentido a suas expressões, é claro que pode ser um instrumento privilegiado para a realização de atividades artísticas interdisciplinares, como sugere Edilene Silva. Porém, não deixa de ser uma solução provisória e mesmo limitada, pois reduz as potencialidades do teatro como área de conhecimento a uma função meramente instrumental, além de ser necessário assegurar que os professores especializados em Dança, Música ou Artes Visuais consigam conduzir o trânsito entre as linguagens artísticas indicadas pelos PCN-Arte.

A questão da atuação polivalente do Professor de Arte por vezes se alicerça em discursos legalistas por parte dos gestores educacionais. Durante trabalho de consultoria que realizei para a Secretaria de Estado da Educação de Alagoas (SEE) no processo de construção dos Referenciais Curriculares para a Educação Básica da Rede Estadual de Ensino, nos anos de 2013 e 2014, ouvi desses gestores que o ensino das quatro linguagens artísticas era "um direito de aprendizagem do aluno", e, diante da ausência de professores especializados, a polivalência nas aulas de Arte seria necessária. Sabemos ser fundamental questionar discursos que usam os direitos do aluno para se legitimarem e que, paradoxalmente, negam os direitos dos professores especializados e, acima de tudo, os deveres do estado em contratá-los, na medida em que tem a responsabilidade de implantar as indicações dos PCN-Arte. E qual a ética desse discurso que ao ignorar intencionalmente a ausência de uma formação genérica dos professores de Arte, não se compromete com a qualidade com que os "direitos do aluno" serão atendidos? 
No momento (março de 2016), o Ministério da Educação vem realizando uma consulta pública para a construção de uma Base Nacional Comum Curricular (BNCC), para a qual apresentou uma versão inicial com o objetivo de promover um amplo debate na sociedade. $\mathrm{Na}$ apresentação da seção dedicada ao agora chamado Componente Curricular Arte, a proposta ratifica a obrigatoriedade do ensino de Música (Lei 11.769/2008) e das demais linguagens artísticas (Projeto de Lei 7.032/2010), agora chamadas de subcomponentes, e faz a seguinte observação: "Ao considerar que a formação em Arte acontece em licenciaturas específicas (artes visuais, dança, teatro e música), é necessário garantir professores habilitados em cada um dos subcomponentes, para todas as etapas da Educação Básica" (BRASIL, 2015 , p. 82). A se continuar essa redação, a futura BNCC, ao que parece, repetirá os PCN-Arte, afirmando que "é necessário garantir" a contratação de professores especializados, mas não obrigando ou criando condições para que essas contratações ocorram de fato.

Desta forma, a legislação do país (PCN, Lei ํo 11.769/08, Projeto de Lei ํo 7.032/10 e futura BNCC) que indica e obriga o ensino de uma linguagem artística através de aulas ministradas por professores especializados, permite que, na ausência destes (por questões trabalhistas ou pelo ainda insuficiente número de licenciados), profissionais formados em outra linguagem possam ministrar aulas daquele componente curricular para o qual não foram capacitados. O que podemos constatar é que com o anunciado fim das licenciaturas em Educação Artística iniciado com a implantação dos PCN-Arte, a definitiva saída de cena do professor polivalente em artes ocorreu apenas no processo formativo, mas não no exercício profissional. A prática polivalente ainda acontece em Alagoas e em outros estados brasileiros, talvez agravada, pois os jovens profissionais não possuem a antiga formação generalista que aparentemente tentava suprir as demandas das escolas.

\subsubsection{Conteúdos curriculares: repetição, aleatoriedade e improvisação}

A professora T. L. abordou o tema Ponto (a arte impressionista) [...] no sexto, nono, sétimo e oitavo ano, sempre com o mesmo assunto para todas as turmas. Achei 
estranho, mas como to no estágio e não [tenho] voz ativa para mudança, apenas observei [Relatório de Estágio].

O estudante de Teatro da UFAL que fez a descrição acima havia se referido a essa situação em seu Estágio anterior, realizado na mesma escola e com a mesma docente, ao relatar que, "segundo a professora é comum a prática de lecionar o mesmo assunto em séries diferentes". Tal conduta é característica na Educação Básica alagoana, encontrada em outros relatórios de estágio realizados em outras escolas e com outros profissionais. Observações como "a professora P. está executando o mesmo plano de aula em todas as turmas" ou "é uma grande sequência de repetições dos mesmos assuntos em todas as salas" não são exceções, mas sim regra nos documentos pesquisados.

A análise de planos de aula e de sequências didáticas presentes nesses relatórios revela o que Regileno Lima (2012) havia constatado em pesquisa realizada em estabelecimentos de ensino particulares, ou seja, "a ausência de práticas artísticas nas escolas em diferentes linguagens da Arte: teatro, música, dança ou artes visuais, cada qual tratada disciplinarmente em sua especificidade" (LIMA, 2012, p. 96). Em nenhum dos relatórios foi encontrada uma organização curricular das linguagens artísticas na forma sugerida pelos PCN-Arte, isto é, a escolha de duas linguagens para cada ciclo, por exemplo, Teatro e Dança para o $3^{\text {o }}$ ciclo (6을 e $7^{\circ}$ anos), e a abordagem das outras duas por meio de projetos interdisciplinares, no exemplo, Música e Artes Visuais, invertendo-se as opções no ciclo seguinte (BRASIL, 1998, p. 47).

Não existem conteúdos curriculares seriados específicos para cada série escolar na disciplina Arte da Educação Básica em Alagoas e, do sexto ano do Ensino Fundamental II à terceira série do Ensino Médio as aulas vão se repetindo, indistintamente. Trata-se de uma situação generalizada e vista como "comum" pelos professores de Arte em exercício. Podemos encontrar as causas para essa situação no próprio sistema educacional alagoano, desde a formação dos professores até as precárias condições de trabalho oferecidas pela rede pública.

Isabel Marques e Fábio Brazil, porém, detectam que este não é um problema localizado, pois, ao observarem que a comunidade escolar e professores de Arte 
desconsideram a necessidade de planejamento na disciplina, afirmam que "não raro, encontramos gestores [...] que convivem muito bem com um 'planejamento' de Arte que se reduz a enfileirar atividades, festinhas e confecção de badulaques artesanais" (MARQUES e BRAZIL, 2014, p. 104). Mais a frente, será problematizada esta perspectiva que rebaixa o fazer artesanal a "badulaques", agora, porém, não se pode deixar de apontar para uma questão específica do ensino das artes na Educação Básica brasileira: a ausência de uma proposta nacional que estabeleça conteúdos seriados para Arte e, como consequência, a ausência de qualquer tipo de controle da sociedade no ensino desses conteúdos. Nos PCN-Arte encontra-se a seguinte orientação sobre este tema:

Cabe à equipe de educadores responsável pelo projeto curricular da escola trabalhar com os professores de Artes Visuais, Dança, Música ou Teatro para fazer um diagnóstico do grau de conhecimento de seus alunos e procurar saber o que já foi aprendido, a fim de dar continuidade ao processo de educação em cada modalidade artística [BRASIL, 1998, p. 62].

Marques e Brazil (2014) defendem perspectiva semelhante ao afirmarem que "é papel do professor estabelecer relações entre a Arte e as outras formas de conhecimento trabalhadas na escola, uma vez que é conhecedor do projeto políticopedagógico que norteia a instituição em que atua" (MARQUES e BRAZIL, 2014, p. 50). Aqui cabe questionar como os professores de Arte poderão "dar continuidade ao processo de educação" de seus alunos ou "estabelecer relações entre a Arte e as outras formas de conhecimento trabalhadas na escola" se: primeiro, não existe a contratação de professores a partir das habilitações especificadas nos PCN-Arte, mas genericamente como professores de Arte; segundo, os professores de Arte, diante da pequena carga horária da disciplina, em geral, ministram aulas em diversas escolas, o que pode inviabilizar o conhecimento específico dos projetos político-pedagógicos de cada uma; terceiro, não existe a definição de qual modalidade (linguagem) artística deve ser tratada em cada série; e, por fim, os conteúdos a serem trabalhados não são apresentados, nos PCN-Arte, em uma sequência que favoreça um diálogo mínimo com as demais disciplinas curriculares da série. 
Talvez, na escola idealizada pelos PCN-Arte, com infraestrutura adequada, professores contratados para trabalhar a partir de suas habilitações e a Arte reconhecida pela comunidade escolar como área de conhecimento, a orientação acima possa ser viabilizada. Porém, da forma precária como o ensino das artes está inserido no sistema educacional alagoano e brasileiro, a proposição de que uma equipe de educadores direcione os conteúdos a serem abordados em cada série vem provocando o contrário do que se pretendia, isto é, a ausência desses conteúdos seriados. Regileno Lima afirma não ter encontrado nenhuma espécie de "avaliação dos projetos desenvolvidos nas escolas como situações de aprendizagem" (LIMA, 2012, p. 96), ou seja, não existem diagnósticos para se "saber o que foi aprendido" em Arte também nas escolas particulares de Maceió.

A legitimação de Arte como área de conhecimento na Educação Básica talvez passe pela necessidade de organização dos conteúdos conceituais presentes no currículo, de forma que se estabeleça um diálogo mínimo com a escola. A recusa em se organizar o currículo nos mesmos moldes que as demais áreas de conhecimento escolar, paradoxalmente, pode dificultar a legitimação do ensino das artes, colocando-as naquelas prateleiras reservadas às disciplinas prescindíveis, desnecessárias para a formação do futuro cidadão, como ainda se ouvem em várias instâncias do sistema educacional brasileiro. Edilene Silva (2013, p. 27) chamou de "ignorância no que diz respeito à arte" por parte da comunidade escolar esta perspectiva que deslegitima a Arte como área de conhecimento e que enfrenta problemas concretos como os relatados a seguir:

No mesmo dia só que em outra turma, encontrei uma situação que pra mim foi inusitada, três turmas numa mesma sala, tínhamos o 60 $7^{\circ}$ e $9^{\circ}$ juntos, e a aula foi a mesma ministrada no $8^{\circ}$ ano. Depois em uma conversa com o professor esclareci o porque de o plano de aula ser o mesmo para as "supostas" quatro turmas, ele então me disse que é realmente pela falta de "oportunidades" de ter turmas separadas e com um bom número de alunos, ele disse que ficaria até inviável para ele fazer isso, até porque mesmo que fizesse quatro planos de aula diferentes não poderia ministrar as aulas, pois as turmas sempre tem aulas juntas" [Relatório de Estágio realizado em turmas de Educação para Jovens e Adultos - EJA].

A reunião em uma mesma sala de aula de turmas de séries diferentes, relatada como "inusitada" pelo estagiário, é, pelo contrário, comum na Educação Básica alagoana, segundo o que foi observado nos relatórios de estágio. A lógica 
para justificar a reunião de séries diferentes em uma mesma aula (mesmo espaço, mesmo professor, mesmos conteúdos) pode ser aquela apresentada pelo professor ao estagiário, na citação acima: como não há "oportunidade" de se ter turmas separadas, o plano de aula é o mesmo para as "supostas" quatro turmas de séries diferentes, justificando-se, assim, a ausência de conteúdos seriados. Talvez a justificativa pudesse ser outra: como Arte não possui conteúdos seriados, não há problema em se juntar turmas de séries distintas em uma mesma aula.

Outra característica se revela nos relatórios de estágio: a aleatoriedade dos conteúdos das aulas de Arte. Um estagiário afirma "que a professora N. não utiliza plano de aula, sendo assim, ela utiliza-se de materiais aleatórios para ministrar as aulas". Os relatórios citam sequências em que se começa com uma aula sobre desenho para, em seguida, ministrar-se uma aula de dramatização; depois, uma aula de história da arte é seguida de outra com atividades plásticas, indistintamente. O que demonstra a ausência de um pensamento pedagógico sistêmico, que se organize através de uma sequência de aprendizados em que as linguagens e os conteúdos dialoguem entre si e com as demais áreas do conhecimento escolar. Em muitos relatos são as datas comemorativas (Dia do Índio, Páscoa, Dia das Mães, Festas Juninas) que servem como temas para a produção de objetos artesanais ou espetaculares, de acordo com a formação do professor, da solicitação dos gestores ou, ainda, das condições materiais da escola. Dificilmente a escolha dos temas comemorativos se insere na proposta didática ou explicita o pensamento pedagógico a ser desenvolvido. O que se depreende dos relatórios é que os conteúdos, os planos de aula e as sequências didáticas são práticas pedagógicas que não fazem parte do dia-a-dia dos professores de Arte em Alagoas.

As condutas, mesmo que ainda observadas e criticadas pelos estagiários, são incorporadas por alguns dos estudantes ainda na regência de suas aulas:

A aula neste dia teve como tema a importância da arte na Grécia, e como o tema era tão bom eu perguntei à professora se poderia dar o mesmo tema para as demais turmas já que isso era uma prática comum dela e de alguns professores, e assim o fiz, no oitavo, sétimos e sextos anos [Relatório de Estágio].

Trata-se de trecho do mesmo relatório daquele estudante que se espantara com a ausência de conteúdos específicos para cada série ("achei estranho, mas 
como to no estágio e não [tenho] voz ativa, apenas observei”) e que, aqui, assume essa prática como "comum" ainda durante o próprio estágio. Atitude observada em outros relatórios, nos quais a aleatoriedade e, principalmente, a repetição dos conteúdos de Arte passaram a se constituir como norma no exercício da profissão.

A ausência de um currículo seriado nacional para Arte pode ser decorrência da sua ainda recente implantação como área de conhecimento escolar, que, ao contrário de outras disciplinas, não possui uma tradição curricular na Educação Básica brasileira. Diante dessa situação, torna-se difícil estabelecer modelos pedagógicos e conteúdo-padrão como estratégia para se evitar a aleatoriedade e/ou a repetição nas sequências didáticas e no ensino das linguagens artísticas. Uma das estratégias que as escolas particulares alagoanas encontraram para enfrentar esse problema é a adoção de materiais didáticos, de livros ou de apostilas produzidas por empresas educacionais conhecidas como "sistemas de ensino". Esses materiais estabelecem uma sequência de conteúdos e, às vezes, de linguagens artísticas a serem abordadas pelo professor, fazendo com que o que deveria ser obrigação do Estado ou da "equipe de educadores responsável pelo projeto curricular da escola" (BRASIL, 1998, p. 62) passe a ser assumido por grandes empresas educacionais do setor privado.

Ao longo do processo tentei usar algumas metodologias, porém a instituição não permitia, pois é trabalhado no formato do sistema adotado por eles, é a única parte do Estágio que não me satisfez de certa forma. [...] No entanto consegui por várias vezes driblar o método trabalhado pelo sistema e utilizar o meu, pois sentia a deficiência de fazer aulas práticas com os alunos pela necessidade de ter que se cumprir um cronograma e terminar um livro de data marcada [Relatório de Estágio].

O relato pode ser indicativo de um viés mercantilista para a educação. Ao contrário da abordagem triangular indicada pelos PCN-Arte no aprendizado das linguagens artísticas (a produção, a fruição e a contextualização), os sistemas de ensino particulares adotam livros e apostilas nos quais "a prioridade será dos conteúdos voltados à História da Arte", conforme consta em outro Relatório de Estágio. Em geral, a escolha desses conteúdos corresponde às solicitações de exames vestibulares e do ENEM (Exame Nacional do Ensino Médio), com o objetivo de preparar os alunos para conquistarem as melhores vagas no Ensino Superior do país, o que garantiria uma espécie de "chancela de qualidade" para as escolas. Não 
se pode afirmar que não exista nenhuma espécie de preocupação pedagógica por parte desses "sistemas de ensino" particulares, mas deve-se considerar que talvez esta organização do currículo de Arte esteja excessivamente comprometida com uma "lógica" de mercado, deixando em segundo plano a formação estética de seus alunos.

Com relação ao conteúdo da disciplina de artes dada na escola privada são mais relacionados à Literatura Brasileira (pintores, escultores conhecidos), do que para a cultura em geral (religiosidade, artistas brasileiros em geral). O da escola pública são mais extensos, busca trazer várias artes, não só as atuais mas também as antigas, acredito que deve ser devido ao fato de o professor ter mais liberdade para mexer no conteúdo, o que na escola privada não ocorre pois o professor deve seguir o livro didático da instituição [Relatório de Estágio].

Ainda que a redação acima seja confusa, um dos possíveis entendimentos para este trecho se refere à falta de liberdade que os professores de Arte encontram nas escolas particulares, o que se deveria à obrigação de se "seguir o livro didático da instituição". Presume-se que os conteúdos desse material didático são selecionados em função de outras disciplinas, no caso, da Literatura Brasileira, o que transforma a disciplina Arte em instrumento e suporte para outras áreas de conhecimento escolarizado. Neste sentido, Regileno Lima afirma que um dos problemas recorrentes encontrados nas escolas particulares de Maceió é "a Arte colocada a serviço de projetos de meio ambiente, saúde, datas comemorativas do calendário escolar e à aprendizagem de outras disciplinas sem ênfase em seus conteúdos próprios" (LIMA, 2012, p. 96).

O aprendizado das linguagens artísticas fica restrito a abordagens contextualistas, que enfatizam "as consequências instrumentais da arte na educação e utiliza[m] as necessidades particulares dos estudantes ou da sociedade para formular seus objetivos" (KOUDELA, 1984, p. 17), conforme Ingrid Koudela define essa categoria sob o ponto de vista do arte educador Elliot Eisner.

Ainda que o estagiário reconheça a liberdade que encontra na escola pública para mexer no conteúdo, a não adoção de livros didáticos para Arte pelos sistemas públicos de educação de Alagoas também pode servir de estímulo e justificativa para as já citadas aleatoriedade e repetição. Regileno Lima vê na "ausência de proposta de aquisição de livros pelo Programa Nacional do Livro Didático (PNLD)" (LIMA, 
2012, p. 96) mais uma forma de desvalorização da área. Em um Relatório de Estágio, um aluno afirma que "o que faltou mesmo foi um livro didático para dar maior suporte ao professor", e acrescenta:

O que pude notar na escola privada é que o material didático já traz tudo a favor do professor e do aluno. O que na escola pública não ocorre, pois o livro disponível que há para o aluno são os livros das disciplinas de Português, Matemática, História, Física, Química e Biologia; mas o livro de artes não é disponível para o aluno, sendo que o conteúdo é o professor quem traz, bem como as xerox para os alunos estudarem [Relatório de Estágio].

Sobra a crítica, o estagiário vê de forma positiva a adoção de apostilas e livros didáticos, pois estes "favoreceriam" não só aos professores, mas também aos alunos. A crítica é pertinente no contexto alagoano, onde o acesso dos alunos a materiais específicos restringe-se a cópias Xerox trazidas pelo professor ou a pesquisas individuais realizadas na internet, geralmente solicitadas como forma de aprofundamento de conteúdos dados em aula. A maioria dos Relatórios de Estágio traz descrições dessa prática, disseminada entre os professores de Arte do Estado.

A ausência de uma sequência comum de conteúdos curriculares e mesmo de livros didáticos que pudessem suprir essa lacuna tende a criar uma espécie de dependência do aluno aos conteúdos selecionados por um único professor. A ocasional substituição do professor de Arte na escola, que seria o único responsável pela seleção dos conteúdos, ou a mudança de escola por parte do aluno podem acarretar consequências danosas à aprendizagem dos componentes curriculares da disciplina.

A escola não tem livros [didáticos] de arte. O professor de arte tem sempre que improvisar pedindo aos alunos que façam pesquisa, vejam vídeos ou tirar xerox do livro [Descobrindo a História da Arte] de Graça Proença [Relatório de Estágio].

Esperava-se que esta situação, denunciada nos próprios PCN-Arte ao se referirem à antiga Educação Artística, na qual "o professor polivalente inventa maneiras originais de trabalhar, munido apenas de sua própria iniciativa e pesquisa autodidata" (BRASIL, 1997b, p. 25), através da formação de professores especializados não mais se repetisse. A improvisação, que deveria ser um recurso pessoal dos professores para o aprofundamento de determinados conteúdos ou 
para a abordagem de outros que não fossem contemplados no currículo ou no livro didático, torna-se, assim, norma e prática exclusiva.

A ausência, no país, de um currículo comum seriado para Arte parece apontar para soluções insatisfatórias na Educação Básica alagoana: a opção por um ensino de Arte que servirá como auxílio na aprendizagem de outras disciplinas, de conteúdos transversais e no acúmulo de informações para se enfrentar os exames vestibulares, ou a aleatoriedade e a repetição na escolha de conteúdos, que, aliadas à improvisação sistemática, demonstram a ausência de um pensamento pedagógico que possa desenvolver junto ao aluno da Educação Básica uma verdadeira formação artística e estética, capaz de potencializar suas capacidades de leitura, escrita e pensamento sobre arte e sobre o mundo. Na primeira opção, o aluno fica refém de uma visão contextualista, em geral a serviço do mercado educacional; na segunda, dos conteúdos trazidos pelo professor.

$\mathrm{Na}$ versão inicial da futura Base Nacional Comum Curricular (BNCC), apresentada como documento base para uma ampla discussão pela sociedade, todos Componentes Curriculares (assim tratados o que aqui chamamos de disciplinas) apresentam seus Objetivos de aprendizagem divididos em anos letivos. As duas exceções são Educação Física, que faz uma divisão do Ensino Fundamental em quatro ciclos, mais o Ensino Médio, e Arte, que os divide somente em três: Ensino Fundamental I (no qual o componente é ministrado por professores com formação em Pedagogia), Ensino Fundamental II e Ensino Médio, sendo que estes devem ser ministrados por professores especializados. Esta versão inicial da BNCC propõe ainda uma segunda divisão dos objetivos por cada uma das quatro linguagens artísticas. Talvez este fosse o momento para se enfrentar a ausência de conteúdos conceituais (ou de objetivos de aprendizagem, como consta na BNCC) seriados, porém o que se percebe é que as entidades representativas dos arte educadores têm se preocupado mais com uma possibilidade de extinção da disciplina Arte, que, ao se tornar um componente curricular, poderia ser "incorporada" em outras disciplinas, do que em discutir este tema. Caso esta versão inicial da BNCC mantenha esses objetivos de aprendizagem de maneira ampla, sem especificações seriadas, ao contrário das demais disciplinas, acredito que o problema aqui apresentado persistirá. 
A última citação de relatório de estágio faz menção ao livro de história da arte adotado pelo professor e aponta para outra característica marcante do ensino de Arte em Alagoas: o predomínio das artes plásticas sobre as demais linguagens artísticas. Tal presença é tão forte e recorrente nas aulas relatadas que parece indicar um possível paradigma no ensino de Arte e será tratado de forma mais extensa a seguir.

\subsubsection{Paradigmas da disciplina Arte}

Antes de começar o estágio regido, pensei em fazer várias coisas, não sabia se iria focar nas aulas de arte tradicionais, onde se utiliza o caderno de desenho, os lápis de cores, os materiais recicláveis ou se iria focar no teatro, já que essa é a minha habilitação, mas ao começar as aulas pensei que não seria tão fácil só focar no teatro, eu tinha que procurar uma forma que pudesse envolver as duas formas que eu pensei, comecei com a história da arte em Alagoas nos sextos anos e com a história da arte no Nordeste [Relatório de Estágio].

O relato acima, além de reafirmar a recorrência de situações analisadas anteriormente, chama a atenção pela expressão "aulas de arte tradicionais". A estagiária, ao se referir a uma possível tradição pedagógica no ensino das artes, associa-a a materiais pedagógicos próprios ao fazer das artes plásticas, o que parece ser um paradigma no ensino de Arte na Educação Básica não só alagoana, mas brasileira.

Marques e Brazil (2014) observam que se perguntássemos a frequentadores de cinemas e fruidores de canções e de telenovelas "se gostam de arte, recuariam e possivelmente responderiam que não - por vezes pensando apenas em pintura -, pois não relacionam suas atividades de lazer/fruição com a palavra arte, mesmo que tenham tido Arte como componente curricular" (p. 22). Para esses educadores, "o adulto fruidor/frequentador de arte - e o não fruidor, não frequentador - raramente relaciona sua vivência de arte, como cidadão, à convivência que com ela teve na escola" (p. 21), pois esta, em geral, tem como referência o fazer das artes plásticas. $\mathrm{Na}$ maioria dos Relatórios de Estágio analisados que registram abordagens de ensino de Arte por meio da criação artística, predomina a linguagem das artes 
plásticas através da produção de cunho artesanal, como a decoração da escola para eventos públicos (festas, feiras de ciência e cultura), de pequenos vasos, de latas de lixo, do reaproveitamento utilitário de garrafas pet, discos de vinil, pneus e outros materiais recicláveis.

Os motivos que fizeram com que as artes plásticas passassem a ocupar um lugar predominante dentro da educação escolar brasileira, associando-as a uma tradição pedagógica nas artes, podem ser decorrentes da criação da antiga Educação Artística. Segundo os PCN para o Ensino Médio, com a vigência da Lei 5.692/71 a arte passou a ser tratada como experiência de sensibilização, o que fez com que nas escolas passasse "a ser entendida como mera proposição de atividades artísticas, muitas vezes desconectadas de um projeto coletivo de educação escolar" (BRASIL, 2000b, p. 47).

Vicente Concílio vê esta situação como consequência do que ele chama de "deformação" das aulas de Educação Artística, caracterizando-a como "a tendência em se privilegiar as artes plásticas, algo que acontece até hoje, mesmo nas universidades, onde ainda se confunde história da arte com história das artes plásticas" (CONCÍLIO, 2008, p. 70). Ainda que não seja o objetivo desta tese investigar quais os motivos da predominância das artes plásticas no fazer artístico escolar, um olhar histórico sobre a arte educação no Brasil, anterior à criação da matéria Educação Artística, em 1971, pode auxiliar no entendimento deste paradigma e as consequentes dificuldades de inserção do ensino do Teatro na Educação Básica.

Ana Mae Barbosa, em seu estudo Arte-educação no Brasil (2012), ao discorrer sobre as mudanças históricas do ensino da arte dentro do currículo da Educação Básica brasileira, nos séculos XIX e XX, registra a presença preponderante das artes plásticas, sendo que o Desenho sempre ocupou posição destacada nesta área. Entre tensões que ora defendiam o Desenho Geométrico como forma de educação exclusiva para o trabalho, ora o Desenho de cópia da natureza ou de estamparias industrializadas, como uma forma de linguagem e de desenvolvimento do raciocínio (BARBOSA, 2012, p. 80), ambos tinham como objetivo educar a mão e o olho das crianças. Mesmo com a introdução de pedagogias norte-americanas e as propostas educacionais realizadas por artistas 
modernistas, como Mario de Andrade e Anita Malfatti, voltadas ao desenvolvimento psicológico da criança e à livre-expressão, o estímulo às expressões gráficas não alterou a posição de destaque do Desenho. Na década de 1950, ainda que componentes curriculares relacionados à linguagem musical tenham sido introduzidos, como Música e Canto Orfeônico, as artes plásticas continuaram no currículo escolar com a manutenção do Desenho e a introdução de Trabalhos Manuais, sendo que este último pode ter influenciado decisivamente no surgimento do paradigma do fazer artesanal e plástico nas aulas de Arte.

A LDB de 1971 (lei 5.692/71), ao concentrar essas e outras linguagens artísticas em uma única "matéria educativa", associada às dificuldades surgidas para a formação de professores polivalentes, reforçou ainda mais as práticas manuais no ensino da arte. A "criação" da Educação Artística, "para a qual não havia profissionais licenciados" (JAPIASSU, 2010, p. 64), fez com que o Ministério da Educação implantasse duas medidas para suprir a demanda nesta área: estimulou a criação de licenciaturas curtas (cursos com dois anos de duração), com formação genérica nas diversas linguagens artísticas, os chamados professores polivalentes, com os quais, esperava-se, o problema seria resolvido em médio prazo; e aceitou como professor da nova matéria docentes de áreas afins ou que possuíssem habilidades artesanais, para resolver o problema em curto prazo. Assim, a ideia de ensino da arte como produção, associada ao desenvolvimento de habilidades manuais, parece ser um dos fatores que fizeram com que o fazer das artes plásticas estabelecesse essa tradição no sistema escolar brasileiro.

Grande parte dos materiais didáticos desenvolvidos na época voltava-se à sensibilização e à auto expressão através do fazer artístico relacionado às artes plásticas, assim professores de outras áreas mais afeitos a essa produção passaram a ministrar a matéria educativa, ajudando a disseminar essa visão que se tornaria paradigmática, como parece ser o caso da professora citada abaixo:

Como a professora não é formada em Teatro e sim tem apenas o Magistério, nota-se uma tendência muito grande às artes plásticas, desenvolvimento de desenhos à mão livre, pintura com tintas e lápis de cor/giz de cera, colagens e outros métodos de inserção das crianças nas artes. Mas muito pouco desenvolvimento de trabalhos teatrais, que nesse caso é inserido como a 'pecinha' de páscoa, de natal, dia das mães etc. [Relatório de Estágio]. 
A proposição de atividades plásticas como conteúdo de Educação Artística também fazia parte do projeto político do regime militar, iniciado em 1964, que interrompeu as experiências com a disciplina arte dramática, realizadas em ginásios vocacionais, colégios de aplicação e escolas pluricurriculares, como afirma Ricardo Japiassu, citando a dissertação de mestrado de Marly de Jesus Bonome Vita, Histórias da história do teatro aplicado à educação:

Com a repressão imposta pelo golpe militar de 1964, os movimentos renovadores foram interrompidos. O teatro ficou rotulado como perigoso inimigo público e as aulas de arte dramática, nessas escolas, mesmo na década de 1970, não eram ignoradas pelo regime militar - que exigia que os textos teatrais trabalhados nessas escolas fossem previamente encaminhados ao Departamento de Censura Federal [VITA apud JAPIASSU, 2010, p. 63].

Não era do interesse da ditadura militar estimular o aprendizado de uma linguagem artística, no caso, o teatro, cujos princípios possuem similaridade à prática política e ao exercício da democracia.

Segundo Hannah Arendt, a Política é uma maneira de pensar no plural, de colocar-se no lugar e na posição de outros, desta forma requer um espaço de diálogo no qual todos tenham o direito de falar e de serem vistos, o que somente pode se dar no mundo público (ARENDT, 2011, p. 17). Tanto o teatro como a Política necessitam que a liberdade de pensamento esteja associada à liberdade de expressão e comunicação, portanto de publicidade. Arendt cita Kant quando este afirma que:

"o poder externo que priva o homem da liberdade de comunicar publicamente seus pensamentos priva-o ao mesmo tempo da liberdade de pensar", e a única garantia para a "exatidão" de nosso pensamento está na circunstância de que "pensamos como em comunhão com outrem, aos quais comunicamos nossos pensamentos assim como nos comunicam os seus". A razão humana, por ser falível, só pode funcionar se o homem pode fazer "uso público" dela [ARENDT, 2011, p. 291, grifo da autora].

Estando suspensos os direitos democráticos dos cidadãos brasileiros de comunicar publicamente suas opiniões - o que comprometeria inclusive a liberdade de pensamento, segundo Arendt -, uma linguagem artística cujos princípios baseiam-se no diálogo travado em público, entre personagens com opiniões 
contrárias e conflitantes, poderia provocar o alargamento da consciência crítica dos participantes e dos assistentes e, desta forma, não seria a mais indicada para ser desenvolvida dentro das salas de aula. Não interessava ao governo militar estimular atividades que pudessem reproduzir formas de organização, pensamento, expressão e comunicação que remetessem às liberdades políticas suprimidas.

Dessa maneira, o contexto político repressivo pelo qual passou o país por mais de duas décadas influenciou na predominância do fazer artístico das artes plásticas nas salas de aula, assim como a inserção do teatro na escola somente como parte de festividades comemorativas, "domesticado" dentro de um tema e, muitas vezes, de uma fábula já conhecida, como faz menção o estagiário ao se referir à "'pecinha' de Páscoa, de natal, dia das mães etc."

Além dessas questões históricas, o paradigma do ensino das artes plásticas também pode ser creditado à ausência de espaços arquitetonicamente adequados para outras formas de arte:

Algumas dificuldades encontradas no decorrer do processo, como: A falta de sala adequada para ensaios, pois sempre ensaiávamos na sala de aula tendo que afastar as cadeiras e como a sala tinha em média 40 alunos muitas vezes ficava inviável algumas aplicações de exercícios, principalmente corporais [Relatório de Estágio].

Ainda que disposto a realizar na regência de aulas de seu estágio uma prática teatral, o estagiário ressente-se de um local adequado para a "aplicação de exercícios, principalmente corporais", para o número de alunos que possui. Caso se queira privilegiar no ensino do Teatro a prática de exercícios corporais e de jogos teatrais, como comumente se faz quando a atividade acontece em ações socioculturais, dificilmente se encontrarão salas de aula amplas e livres do mobiliário escolar.

Esta situação, relacionada à infraestrutura arquitetônica das escolas, é disseminada na realidade alagoana e pode ser constatada através dos questionários presentes nos Relatórios de Estágio preenchidos pelos estudantes. Nas questões que se referem às instalações da escola, há o seguinte item: "Salas para aulas de Teatro, Música ou Dança", para o qual quarenta e cinco (45) respostas indicaram não haver espaço específico e catorze (14) indicaram haver algum espaço 
específico, sendo que destas, oito (8) se referiam a escolas públicas e seis (6) a particulares. É importante frisar que estes números não são totalmente confiáveis, pois algumas escolas, ao receberem vários estagiários em diferentes momentos, foram computadas mais de uma vez, e mesmo estas recebiam respostas contraditórias, de acordo com o entendimento que cada estagiário possuía de salas adequadas. Porém não seria leviandade afirmar que em cada cinco escolas alagoanas, quatro não possuem espaço adequado para aulas de Teatro, Música ou Dança. Se se considerar que algumas atividades relacionadas à produção e à contextualização das artes plásticas podem ser realizadas em salas de aula padrão, sobre as carteiras enfileiradas, diferentemente das necessidades das demais linguagens artísticas, essa organização espacial tradicional pode concorrer para a continuidade deste paradigma.

Outro paradigma do ensino da Arte em Alagoas refere-se à espetacularidade nas abordagens das artes cênicas. Nos sessenta e dois (62) relatórios de Estágio Supervisionado analisados não foi encontrada nenhuma citação ao ensino da Dança em que as aulas tenham se desenvolvido a partir da abordagem triangular proposta nos PCN-Arte, isto é, através da produção, contextualização e fruição da obra de arte. O registro da ausência de abordagens triangulares não significa, entretanto, que esta linguagem artística não seja trabalhada nas aulas de Arte em Alagoas, pois tanto no ensino da Dança, como no do Teatro, predominam as produções espetaculares, conforme já foi observado em algumas passagens de relatórios citados anteriormente (a alegria do estagiário que ajudara na produção de uma peça a ser apresentada no Natal e a crítica feita por outro à "pecinha de páscoa, de natal, dia das mães etc.").

Durante o período que estagiei no Colégio S. J. [particular] pude perceber que o que mais se propaga acerca do que o professor de Teatro precisa ensinar na sala de aula - ensaiar os alunos para um espetáculo no final do ano. Esta ideia, preconcebida, povoa a mente de todos os professores do colégio, como se ter um professor de Teatro significasse, necessariamente, ter um profissional pronto para produzir espetáculos [Relatório de Estágio].

O entendimento das artes cênicas somente a partir de suas características espetaculares é disseminado no contexto educacional alagoano, o que tende a restringir a atuação do Professor de Teatro, "necessariamente", à produção de 
espetáculos. Em se tratando de uma escola particular, a afirmação do estagiário corrobora com a pesquisa de Regileno Lima, que constatou que " $80 \%$ das escolas quando contratam um professor de teatro é para atividades extra classe, tais como ensaio de peça teatral ou tarefa para alguma data específica" (LIMA, 2012, p. 96), a tal "pecinha de páscoa" já citada. A perspectiva estritamente espetacular, "ideia preconcebida" entre os demais "professores do colégio", pode ser fruto tanto da aludida dificuldade de entendimento e de conceituação das artes e do teatro, neste caso, por parte da comunidade escolar, como também da "tradição" do fazer, disseminada pela Educação Artística e aqui transposta das artes plásticas para as artes cênicas. Frise-se que esta visão não é exclusiva das instituições privadas de ensino.

Infelizmente é desse modo que alguns professores que poderemos chamar de "multifuncionais", ou até aqueles que se formaram em artes plásticas veem o Teatro, como uma forma de entreter os pais em datas comemorativas e mostrar seus filhos vestidos de algum bichinho, que muitas vezes não tem nem cunho educativo [Relatório de Estágio].

Se na citação anterior o estagiário demonstrava preocupação com a visão restrita à produção de caráter espetacular que professores e gestores escolares possuem do ensino escolar do Teatro, nesta a crítica é direcionada aos próprios professores de Arte, sejam aqueles com formação polivalente (chamados "multifuncionais" no relatório), sejam aos que possuem habilitação em artes plásticas. Não se trata aqui de realizar uma crítica negativa às abordagens pedagógicas realizadas através da produção espetacular, já que as mesmas serão retomadas no quarto capítulo como uma possibilidade de ensino da linguagem teatral na formação de professores de Teatro. Trata-se de questionar uma visão do ensino do Teatro restrita a esse caráter espetacular, que pode reduzir a potência educativa do teatro para seus realizadores, sejam os alunos, seja o professor.

Os PCN-Arte procuram contextualizar historicamente na primeira metade do século XX um dos motivos para o estabelecimento deste paradigma da espetacularização no ensino das artes cênicas dentro das escolas:

As atividades de teatro e dança não estavam incluídas no currículo escolar como práticas obrigatórias, e somente eram reconhecidas quando faziam parte das festividades escolares na celebração de datas como Natal, Páscoa ou Independência, 
ou nas festas de final de período escolar. O teatro era tratado com uma única finalidade: a da apresentação [BRASIL, 1998, p. 24].

A visão arraigada no ambiente escolar, que reduz as artes cênicas ao seu caráter espetacular e com finalidades comemorativas, é também fruto do processo histórico de inserção dessas linguagens artísticas na escola por meio de atividades extracurriculares. Transformadas em componentes curriculares obrigatórios somente

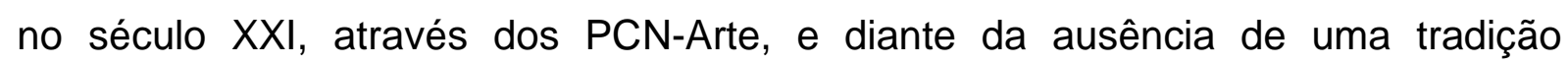
curricular, os paradigmas do fazer e do espetacular acabam por ser impor.

O paradigma da espetacularidade nas artes cênicas aparece com maior frequência nos Relatórios de Estágio em relação ao ensino da Dança, nos quais as referências ao predomínio do caráter estritamente espetacular desta linguagem artística são encontradas em $100 \%$ desses relatórios. Tal unanimidade pode ser creditada ao universo desta pesquisa, exclusivo aos relatórios produzidos por estudantes de Teatro, não incluindo, portanto, aqueles realizados pelos estudantes do curso de Dança Licenciatura da UFAL. Pois no caso dos Relatórios de Estágio do curso de Teatro foram encontradas referências a abordagens que inicialmente tinham como objetivo a montagem e apresentação de um espetáculo teatral, mas que, devido à intervenção dos próprios estagiários, foram introduzidos jogos dramáticos e teatrais como prática didática dos processos de montagem.

O ensino e a aprendizagem da Dança e do Teatro restritos à produção e ao paradigma espetacular, ao não abordarem pedagogicamente os aspectos relacionados às poéticas, à estética e à contextualização histórica, geográfica, sociológica e antropológica, podem retirar das artes cênicas tanto seu potencial de conhecimento e reconhecimento do mundo, como desvalorizá-las enquanto patrimônio cultural da humanidade.

\subsection{O Professor de Teatro nos PCN-Arte}

A formação de professores de Teatro para atuar na Educação Básica quando analisada sob a perspectiva dos TCC e dos Relatórios de Estágio produzidos no 
curso de Teatro Licenciatura da UFAL mostra uma série de problemas observados pelos estudantes que parecem apontar para uma espécie de divórcio entre o Ensino Superior e a Educação Básica no Brasil, no que se refere ao ensino de Arte. Uma incompatibilidade de gênios entre esses dois ambientes educativos que pode ser consequência de um desencontro anterior à ida dos estudantes de Teatro para as salas de aula da Educação Básica e que se revela nas reclamações quanto à perceptível desvalorização do ensino das artes em relação às demais disciplinas presentes nos currículos escolares. Edilene Silva relata:

Certa vez fui abordada sobre o seguinte ponto: "O ensino das artes não é importante no ensino básico, não há a necessidade do ensino arte”. [...] Para mim é inadmissível que alguém cujo cargo esteja inserido na prática escolar independente de qual ele seja, possa mencionar que a disciplina arte tem um grau de importância inferior aos demais [SILVA, 2013, p.28].

Esse exemplo não é uma novidade para os professores de Arte que atuam na Educação Básica, e pode-se até mesmo afirmar que a não "necessidade do ensino arte" na escola é opinião disseminada em vários setores da sociedade brasileira. $O$ que Edilene Silva, que já havia mencionado uma espécie de "ignorância no que diz respeito à arte" (p. 27) por parte da comunidade escolar, não consegue admitir é que alguém que tenha um "cargo", isto é, uma pessoa que exerça uma função administrativa e de gestão dentro da escola compartilhe dessa opinião.

O "grau de importância inferior" às demais disciplinas não se expressa somente na quantidade reduzida de aulas de Arte na oferta curricular alagoana $^{7}$ e na dificuldade de sua legitimação como área de conhecimento dentro do ambiente escolar, mas parece atravessar todo o sistema educacional brasileiro.

Concluí que o ensino de arte é meramente com o objetivo de atender à exigência do MEC (dos Parâmetros Curriculares), porque na verdade arte ainda continua sendo disciplina sem muita "importância" no âmbito escolar [Relatório de Estágio].

\footnotetext{
${ }^{7}$ A disciplina Arte ocupa uma aula semanal de cinquenta minutos, para os cursos diurnos, e de quarenta e cinco minutos, para os cursos noturnos, na matriz curricular das escolas públicas alagoanas, enquanto os PCN-Arte recomendam pelo menos duas aulas semanais (BRASIL, 1998, p. 47)
} 
O estagiário quando conclui que o objetivo do ensino das artes é o de atender às exigências do MEC parece indicar, além da falta de compreensão da área como campo de conhecimento, ou seja, uma "disciplina sem muita 'importância' no âmbito escolar", que Arte só está no currículo por força da lei. Neste sentido diante de qualquer outra necessidade da escola as aulas de Arte ficam submetidas a diversos desmandos, tais como a reunião de turmas de séries diferenciadas em um mesmo espaço e a mudança constante dos locais de aula. Conteúdos, projetos pedagógicos, sequências didáticas, tão importantes para outras disciplinas, são desprezados quando se referem às aulas de Arte. Somente a sensação de se estar realizando uma atividade que aparenta não ser bem-vinda, mas apenas tolerada dentro da escola, pode explicar a frase de uma estagiária: "há de se ter muita boa vontade..."

A maneira meramente "legalista" de se ver o ensino de Arte, na qual os objetivos educativos parecem ser secundários, pode ser encontrada em outras instâncias do sistema educacional alagoano, como presenciei na Secretaria de Estado da Educação e do Esporte (SEE), em finais do ano de 2013 e início de 2014. O relato de minha contratação pela SEE como consultor para a área de Arte pode servir como um exemplo para as conjecturas apresentadas acima.

Inicialmente, fui contatado para atuar como consultor de Teatro junto aos funcionários da SEE e aos professores de Arte da rede estadual no processo de construção dos Referenciais Curriculares para a Educação Básica de Alagoas. Deveriam ser contratados também docentes do ensino superior de Dança, Música e Artes Visuais, linguagens artísticas indicadas nos PCN-Arte, e aos quatro consultores caberia, inclusive, a redação dos textos da área de Arte para o documento final, que serve como parâmetro aos professores da rede pública alagoana para a implementação efetiva dos Referenciais em sala de aula. Esse primeiro contato aconteceu com o processo em andamento há quatro meses, sendo que dois grandes encontros entre os consultores das demais áreas e professores da rede pública estadual, dentre eles, os professores de Arte, já haviam sido realizados. Logo no início dos trabalhos, e ao contrário do que fora combinado, a consultoria contratada passou a ser para todos componentes curriculares da área de Arte, pois se alegavam dificuldades em se conseguir os demais consultores. As dificuldades, 
aliadas ao argumento de que o consultor especializado na linguagem teatral saberia transitar entre as quatro linguagens, justificaria, segundo os funcionários da SEE, a presença de apenas um consultor para toda a área. E assim foi.

O atraso na contratação da consultoria de Arte, a última a ser realizada e que comprometeu dois dos três contatos diretos com os professores da área, corrobora com a afirmação do estagiário de que o objetivo do ensino das artes seria meramente o de atender às exigências do MEC. Houvesse uma preocupação com a área de Arte semelhante a que se teve com as outras áreas de conhecimento escolar jamais se faria um encontro estadual com os professores da disciplina sem a presença dos consultores da área. Por outro lado, a aparente preocupação em atender à legislação educacional, e somente a ela, revelou, paradoxalmente, o desconhecimento da área por parte dos gestores do sistema educacional alagoano, ao reproduzir, na contratação de uma única consultoria para Arte, a polivalência que se queria superar com os PCN-Arte.

O que esse relato indica corrobora com observações encontradas nos documentos pesquisados neste trabalho. Conclusão semelhante é encontrada no relatório de um estudante de Teatro da UFAL, referindo-se à escola pública em que realizou seu estágio, a de que "mesmo o colégio tendo a disciplina Artes, eles [gestores e educadores] ainda não têm noção da importância dessa disciplina na sala de aula para os alunos e nem a importância da Arte na escola". Neste mesmo sentido, Regileno Lima conclui sua pesquisa ao afirmar que "as escolas de Maceió não têm conhecimento do que se pretende alcançar com o ensino da Arte" (LIMA, 2012, p. 79). As duas conclusões confirmam o que professores das licenciaturas em Dança e em Teatro do Brasil denunciaram, em Carta aberta aos governos e gestores educacionais ${ }^{8}$ :

Temos constatado, estarrecidos, que ainda em 2015 alguns gestores e autoridades das Secretarias de Educação Municipais e Estaduais e inclusive gestores de Institutos

\footnotetext{
${ }^{8}$ A carta foi elaborada e divulgada pelas docentes Celida Salume, da Universidade Federal da Bahia (UFBa), Luciana Hartmann, da Universidade de Brasília (UnB), e Taís Ferreira, da Universidade de Pelotas (UFPel), e circulou entre os docentes de licenciaturas em Teatro, Dança e Artes Cênicas do Brasil, na forma de abaixo assinado e por meio de correio eletrônico, no mês de março de 2015. A íntegra encontra-se nos anexos (Anexo A). Mais a frente, trataremos de outros conteúdos presentes nesta Carta.
} 
Federais (que possuem ensino médio) de nosso país desconhecem as referidas leis [LDB de 1996 e PCN-Arte], pois seguem realizando concursos de caráter genérico na área de Artes e/ou desconsiderando as formações específicas. Verificamos da mesma forma a falta de clareza por parte de muitos professores, diretores e gestores sobre como se planeja e operacionaliza o currículo nessas distintas linguagens artísticas [Anexo A].

$\mathrm{Na}$ pedra encontrada no meio do caminho, o que estarrece aos professores das licenciaturas em artes cênicas é uma questão a ser investigada: por que a LDB, após quase vinte anos de sua aprovação, e os PCN-Arte, publicados há mais de quinze anos, mesmo sendo tão claros quanto à importância das artes para a "formação dos indivíduos" (BRASIL, 1998, p. 26), legitimando-as como área de conhecimento, ainda não conseguiram reverter visões que deturpam e desvalorizam o ensino das artes na Educação Básica brasileira? Por que a comunidade escolar ainda não possui "clareza [...] sobre como se planeja e operacionaliza o currículo" de Arte?

\subsubsection{A concretização possível dos ideais da década de 1980: LDB e PCN-Arte}

As leis "são motivadas por valores sociais sentidos pelo governante, parlamentar ou grupo de cidadãos, ou resultantes da observação direta de sua necessidade", segundo Carlos Schmiegel (2010, grifo do autor). Compostas por normas jurídicas, cuja validade depende "de sua concordância com a realidade" (Kelsen apud SCHMIEGUEL, 2010), integram a categoria das normas sociais. "Normas sociais, por sua vez, são criação humana, ou mais exatamente, são produto da cultura humana e são adaptáveis ao momento histórico, aos valores sociais de cada povo e ao lugar em que devam ser aplicadas, segundo a evolução cultural." (SCHMIEGUEL, 2010).

As normatizações jurídicas são, assim, reflexos de valores socioculturais de uma sociedade, ainda que a sociedade a que se refere este trabalho, a brasileira, se reconheça como um país no qual as leis "pegam" ou "não pegam". No Brasil, em muitos setores da sociedade, "as leis viraram remédio para todos os males", segundo Pedro Vals Feu Rosa (2014), pois, através delas espera-se atingir uma vida 
social mais saudável, como num passe de mágica. Remédios que procuram intervir em nossos valores sociais objetivando uma melhoria da própria sociedade, ou seja, apontam no sentido da construção de uma sociedade ideal.

A Lei de Diretrizes e Bases da Educação Nacional - LDB (n. 9.394/96) (BRASIL, 1996), proposta pelo Senador Darcy Ribeiro, contém esse desejo de se construir uma sociedade melhor e mais justa através da educação da população brasileira, ainda que tenha sido duramente criticada pelos educadores do país quando de sua apresentação e votação no Congresso Nacional. Célia Regina Otranto, em artigo de 1996, redigido no calor dos debates legislativos, descreve o trâmite da Lei no Congresso Nacional e as articulações políticas realizadas para sua aprovação: "O Senador Darcy Ribeiro [...] apresenta uma nova proposta de LDB para o país, de sua autoria, sem qualquer consulta anterior a nenhuma instância representativa dos educadores. Para isto, ele se utilizou [de uma] questionável manobra regimental" (OTRANTO, 1996). Segundo a autora, "educadores de todo o Brasil protestaram e começaram a mobilizar-se contra aquilo que consideraram uma manobra e um desrespeito a todo o processo democrático de construção de uma lei que visa traçar as diretrizes educacionais do país" (1996). Os educadores contrários à proposta de Darcy Ribeiro são derrotados, a lei é aprovada na Câmara dos Deputados em 17 de dezembro de 1996 e sancionada pelo Presidente Fernando Henrique Cardoso no dia 20 do mesmo mês.

Otranto, em seu relato, ainda faz menção a centenas de emendas de deputados e senadores incorporadas ao projeto original de Darcy Ribeiro. Bem ou mal, o Brasil entrava o ano de 1997 com uma nova LDB, que, em suas contradições, talvez refletindo mais o pensamento dominante de grupos que detém o poder no país, do que um possível senso comum da sociedade brasileira, menciona o ensino das artes em três momentos. Primeiramente, no artigo 26으, que trata das bases nacionais comuns do currículo do ensino fundamental e médio, que trazia em seu parágrafo $2^{\circ}$ : "O ensino da arte constituirá componente curricular obrigatório, nos diversos níveis da educação básica, de forma a promover o desenvolvimento cultural dos alunos" (BRASIL, 1996) ${ }^{9}$, reafirmando a obrigatoriedade estabelecia pela LDB

${ }^{999}$ A redação deste parágrafo da lei foi alterada em 2010, o que será tratado do capítulo 4. 
anterior, lei 5.692 de 1971, e que não constava na proposta inicial do senador. O artigo $32^{\circ}$ trata do ensino fundamental, que tem "por objetivo a formação básica do cidadão", e diz em seu inciso II que isto se fará mediante "a compreensão do ambiente natural e social, do sistema político, da tecnologia, das artes e dos valores em que se fundamenta a sociedade", associando, desta forma, o acesso às artes e o conhecimento artístico à cidadania. Por fim, o artigo $36^{\circ}$, que trata do currículo do ensino médio, observa em seu inciso I que dentre suas diretrizes está "a compreensão do significado da ciência, das letras e das artes".

As três menções presentes na LDB de 1996 fazem parte dos princípios sobre os quais se construíram os Parâmetros Curriculares Nacionais em relação à área de Arte, ou seja, a obrigatoriedade e o consequente direito de todo aluno ao ensino e à aprendizagem artística; a compreensão de que a produção artístico-cultural de uma sociedade é parte intrínseca da e na formação do cidadão; e o entendimento de que os saberes e conhecimentos relacionados às diversas linguagens, manifestações e formas de produção artísticas são tão importantes na educação escolar quanto os conhecimentos vindos da ciência e das letras.

A ausência de participação efetiva dos educadores brasileiros na formulação da LDB, denunciada por Otranto, pôde, de certa forma, ser revertida na elaboração dos PCN. Segundo consta na introdução deste documento, na segunda fase de sua elaboração houve um "processo de discussão de âmbito nacional" do qual participaram

docentes de universidades públicas e particulares, técnicos de secretarias estaduais e municipais de educação, de instituições representativas de diferentes áreas de conhecimento, especialistas e educadores. Desses interlocutores foram recebidos aproximadamente setecentos pareceres sobre a proposta inicial, que serviram de referência para sua reelaboração (BRASIL, 1997, p. 15).

O processo de consulta, em sua terceira fase, foi ampliado por meio da realização de encontros regionais que incluíram "a participação de professores do ensino fundamental, [...] membros de conselhos estaduais de educação, representantes de sindicatos e entidades ligados ao magistério" (p. 15). 
No caso específico dos PCN-Arte, mesmo com as contradições inerentes ao contexto político de sua criação, foram incorporadas propostas surgidas nas lutas históricas de professores de Educação Artística e de arte educadores. Arão Paranaguá de Santana, que também atuou como parecerista na formulação desses PCN, relata, de forma extensa e retrospectiva (SANTANA, 2009, p. 89-104), toda movimentação desses profissionais em congressos, fóruns e simpósios voltados às licenciaturas em Arte e em Teatro, que antecederam a formulação dos Parâmetros:

Se nas décadas de 70 e 80 disseminou-se uma vasta discussão acerca dos descaminhos da licenciatura em Educação Artística e do seu ensino escolar propriamente dito, os anos 90 foram marcados pela produção teórica e consolidação de um movimento de transformação na esfera da legislação e do currículo [p.19].

A organização dos chamados arte educadores havia se iniciado ainda na década de 1980 com a criação de várias entidades de classe regionais e nacionais e a realização de diversos encontros e simpósios, como relata Ana Mae Barbosa, em artigo publicado na Revista Estudos Avançados da USP, em 1989. Pode-se medir a força da categoria naquele momento, segundo a autora, através da pressão que exerceu sobre deputados constituintes para que inserissem na Constituição Brasileira de 1988, na seção sobre Educação, artigo 206, parágrafo II: "liberdade para aprender, ensinar, pesquisar e disseminar pensamento, arte e conhecimento." (BARBOSA, 1989, p. 173, grifo nosso).

Nesta perspectiva de lutas, em que se procura aproximar o ensino das artes no contexto escolar a uma formação vista como ideal pelo movimento dos arte educadores, é que se insere o processo de criação dos Parâmetros Curriculares Nacionais voltados às artes. Os PCN, de uma forma geral, se constituem como um referencial de qualidade para a Educação Básica com a função de orientar ações educativas do ensino obrigatório, não se configurando, porém, como um modelo curricular homogêneo. Ainda que não se coloquem como impositivos, reafirmam a obrigatoriedade do ensino da Arte como área curricular e estabelecem como um de seus princípios que as condições de fruição da arte e das mensagens estéticas sejam vistas como parte do exercício de cidadania (BRASIL, 1997a, p. 13).

Ainda que sob a concepção geral do pensamento neoliberal, dominante naquele final de milênio, que objetivava inserir o Brasil no mercado globalizado 
também através da educação pública, conforme denuncia Newton Duarte (2006), a nova legislação era a possibilidade de realizar algumas mudanças no ensino das artes, que apontavam para um ideal possível naquele contexto, dentro do sistema educacional brasileiro.

\subsubsection{Da "atividade educativa" Educação Artística para a disciplina Arte}

A passagem de Educação Artística para Arte não foi somente uma troca de nomenclatura em relação ao ensino das artes na Educação Básica brasileira. Ou, pelo menos, não era essa a intenção, ao contrário do que aparentam as práticas escolares presentes nos Relatórios de Estágio e nos TCC produzidos pelos alunos de Teatro Licenciatura da UFAL. As maiores conquistas do movimento de Arte Educação, incorporadas à LDB de 1996 e aos PCN-Arte, são a obrigatoriedade do ensino das artes e mudanças significativas relacionadas ao conceito de arte, ao espaço ocupado pela área dentro do ensino escolarizado, às suas formas de abordagem pedagógica, à indicação de linguagens artísticas como componentes curriculares e à formação dos professores.

A obrigatoriedade do ensino das artes já constava na LDB anterior, Lei 5.692/71, porém não integrava o primeiro Projeto de Lei apresentado ao Congresso Nacional pelo senador Darcy Ribeiro para a LDB de 1996. Foi durante a vigência da LDB de 1971, através da Educação Artística, que

a arte passa a ser tratada como experiência de sensibilização e como conhecimento genérico mas, contraditoriamente, deixa de ser valorizada como conhecimento humano, histórico e importante na educação escolar. Nas escolas, a arte passou a ser entendida como mera proposição de atividades artísticas, muitas vezes desconectadas de um projeto coletivo de educação escolar [BRASIL, 2000, p. 47].

A legitimação das manifestações artísticas como área de conhecimento, afirmando sua importância na educação escolar, inicia-se a partir da implantação dos PCN, em 1997. É quando as artes passam a ser reconhecidas como "um modo particular de dar sentido às experiências das pessoas" (BRASIL, 1997b, p. 15), e não como a "mera proposição de atividades artísticas", como eram entendidas até 
então. Conectada a um projeto coletivo, Arte passa a ser uma das oito áreas de conhecimento $^{10}$ no Ensino Fundamental e, ao contrário da antiga Educação Artística, sua função dentro da educação escolar é considerada "tão importante quanto a dos outros conhecimentos no processo de ensino e aprendizagem" (p. 16), tendo em comum com as demais áreas seu "caráter de busca de sentido, criação e inovação" (BRASIL, 1998, p. 30). Ainda segundo os PCN-Arte, é através do ato criador, presente em qualquer área do conhecimento, que "o homem estrutura e organiza o mundo" (p. 30).

Já o Ensino Médio, baseado no entendimento de que "os conhecimentos estão cada vez mais imbricados" (BRASIL, 2000a, p.18), está dividido em três grandes áreas ${ }^{11}$, das quais Arte integra a de Linguagens, ao lado de Língua Portuguesa, Língua Estrangeira Moderna, Educação Física e Informática. Segundo os PCN para o Ensino Médio, estes conhecimentos carregam "dentro de si uma visão de mundo, prenha de significados e significações que vão além do seu aspecto formal." (BRASIL, 2000b, p. 6). A legitimação de Arte como área de conhecimento e como linguagem procura desfazer o senso comum de que as manifestações artísticas e o conhecimento sensível do mundo não possam fazer parte da educação escolar:

Observando a nossa história de ensino e aprendizagem de Arte na Escola Média, nota-se um certo descaso de muitos educadores e organizadores escolares, principalmente no que se refere à compreensão da Arte como um conhecimento humano sensível-cognitivo, voltado para um fazer e apreciar artísticos e estéticos e para uma reflexão sobre sua história e contextos na sociedade humana. Isso tem interferido na presença, com qualidade, da disciplina Arte no mesmo patamar de igualdade com as demais disciplinas de educação escolar [p. 46].

Instituída sua obrigatoriedade nos anos finais do Ensino Fundamental, que correspondem ao terceiro ciclo (atuais $6^{\circ}$ e $7^{\circ}$ anos) e quarto ciclo (atuais $8^{\circ}$ e $9^{\circ}$ anos), e no Ensino Médio, e legitimando-se como área de conhecimento, Arte passa a ser reconhecida como disciplina, ao contrário da antiga Educação Artística,

\footnotetext{
${ }^{10}$ Além da Arte, são consideradas áreas de conhecimento no Ensino Fundamental Língua Portuguesa, Matemática, Ciências Naturais, História, Geografia, Educação Física e Língua Estrangeira.

${ }^{11}$ As três áreas do Ensino Médio são Linguagens, Códigos e suas Tecnologias, Ciências da Natureza, Matemática e suas Tecnologias e Ciências Humanas e suas Tecnologias.
} 
considerada uma "atividade educativa". A diferença de status que equipara a Arte às demais disciplinas curriculares já se encontrava na lei 9.394/96 (LDB), na qual consta, em seu "artigo 92 das Disposições Transitórias, a revogação do Parecer 549/77 (que desautorizava a reprovação do aluno em educação artística nas séries de $1^{\circ}$ e $2^{2}$ graus - atuais ensinos fundamental e médio)" (JAPIASSU, 2010, p. 66).

A autorização para a reprovação na disciplina Arte, ao contrário do que ocorria na antiga Educação Artística, que não exigia notas porque era "concebida como uma atividade, mas não como uma disciplina de acordo com interpretações da lei educacional 5.692" (BARBOSA, 1989, p. 172), talvez se enquadre naquelas leis que "não pegam" no Brasil. A mudança de status parece ainda não ter surtido o efeito desejado, como se pode ler na conclusão de um Relatório de Estágio Supervisionado: "as escolas ainda tratam o teatro como uma disciplina que não reprova e extracurricular". Se as leis carregam em si o desejo de mudanças e de melhoria da sociedade na qual interferem, e que poderiam fazer com que o ensino de Arte se aproximasse de um ideal possível para a realidade escolar brasileira, o tratamento que esta área do conhecimento recebe ainda hoje por parte de setores e agentes do sistema educacional é a constatação de que esse desejo ainda está longe de se concretizar.

\subsubsection{Linguagens artísticas como componentes curriculares}

Os PCN-Arte indicam que as artes a serem trabalhadas na Educação Básica são aquelas relacionadas às artes cênicas, plásticas e musicais, destacando quatro linguagens artísticas, Teatro, Dança, Música e Artes Visuais, vistas como componentes curriculares da disciplina Arte. As quatro linguagens artísticas devem estar presentes em todos os níveis de ensino, porém o documento deixa a critério das escolas e dos professores quando cada uma pode ser trabalhada (BRASIL, 1998, p. 62), como se pode ver no exemplo dado a seguir:

É necessário que a escola planeje para cada modalidade artística no mínimo duas aulas semanais e que a área de Arte esteja presente em todos os níveis de ensino. Para tanto, sugere-se que, por exemplo, se Artes Visuais e Teatro forem eleitos 
respectivamente em duas das séries de um ciclo, as demais formas de arte poderão ser abordadas por meio de projetos interdisciplinares, com visitas a espetáculos, apresentações ou apreciação de produções em vídeo, pôsteres, etc. A mesma escola trabalhará com Música e Dança nas demais séries, invertendo a opção pelos projetos interdisciplinares [p. 47].

O texto dos PCN-Arte sugere que um componente curricular seja predominante a cada ano letivo, realizando as necessárias conexões com as demais linguagens artísticas, o que obrigaria a contratação de professores especializados nas quatro linguagens em todas as escolas de Educação Básica do país. Assim, pode-se entender, por exemplo, que a escolha da linguagem teatral para uma série letiva associada à contratação de um Professor de Teatro poderiam legitimar este componente curricular como disciplina escolar daquela série. Ou seja, a disciplina seria Teatro e não Arte.

Porém, não é esse o entendimento legal da matéria. Os componentes curriculares não são, necessariamente, uma disciplina escolar, de acordo com 0 parecer do Conselho Nacional de Educação, no 16/2001 ${ }^{12}$. Segundo o relator Nelio Marco Vincenzo Bizzo:

O artigo 26 da LDB cita como componentes curriculares o estudo da língua portuguesa e da matemática, o conhecimento do mundo físico e natural e da realidade social e política, especialmente do Brasil. Além deles, são citados o ensino da arte, o ensino da História do Brasil, o ensino de uma língua estrangeira moderna, ao lado de educação física.

[...] Alguns componentes curriculares especificados correspondem literalmente a nomes consagrados de disciplinas do ensino fundamental, como é o caso de Língua Portuguesa e Matemática. Mas certamente esse não é o caso de conhecimento do mundo físico e natural, [...] realidade social e política e mesmo de História do Brasil.

[...] Portanto, o exame da LDB e do Parecer CNE/CEB 05/97 que a esclarece, não permite concluir que os componentes curriculares devam configurar disciplinas [...] homônimas [BRASIL, MEC, 2001, grifo nosso].

O relator conclui que "não existe vinculação direta entre componente curricular, mesmo obrigatório, e disciplina específica no currículo de ensino", o que se configura como um argumento legal para a continuidade do exercício da polivalência nas aulas de Arte. Diante desta possibilidade de ensino polivalente, que

\footnotetext{
${ }^{12}$ Este parecer se refere a não obrigatoriedade de contratação de professores de Educação Física para ministrar este componente curricular nas séries inicias do Ensino Fundamental I, e cita o ensino da arte como exemplo. A íntegra do documento se encontra nos anexos deste trabalho (Anexo B).
} 
compromete até mesmo a presença das quatro linguagens artísticas nas aulas de Arte, como demonstrado anteriormente nas reflexões feitas a partir dos Relatórios de Estágio, foram aprovadas pelo Congresso Nacional a Lei Federal oㅜ 11.769/2008, que torna o ensino de Música obrigatório, devendo ser ministrado por professores com Licenciatura Plena em Música, e o Projeto de Lei oํ 7.032/10, que torna conteúdo obrigatório na Educação Básica o ensino de artes visuais, das artes cênicas e da música, mas não cita a obrigatoriedade desses conteúdos serem ministrados por professores especializados.

A lógica de que os conteúdos obrigatórios presentes no componente curricular Teatro, associados ao ensino da linguagem teatral, devem ser ministrados por professores com Licenciatura Plena em Teatro está implantada no Ensino Superior mas não na Educação Básica do país. A situação parece confirmar o receio presente nos PCN para o Ensino Médio, ao referir-se aos estudos das linguagens artísticas, quando alertava que "na escola, a transposição didática desses estudos pode refletir o conservadorismo de determinados pontos de vista que nada possuem de teóricos e são fundados no senso comum." (BRASIL, 2000b, p. 8).

\subsubsection{Abordagem pedagógica}

$\mathrm{Na}$ passagem da "atividade educativa" Educação Artística para a disciplina obrigatória Arte, algumas das maiores conquistas do movimento de Arte Educação referem-se à mudança do conceito de arte e ao espaço ocupado pela área dentro do ensino escolarizado, que influenciaram diretamente nas propostas de abordagem pedagógica presentes nos PCN-Arte.

Ao se legitimarem as artes como área de conhecimento (em todos os níveis educacionais) e como linguagem (no Ensino Médio), o ensino de Arte na escola transformou-se, tornando-se mais complexo e ampliando o significado de seu aprendizado, anteriormente restrito, em muitos casos, à expressividade. Neste sentido, os PCN indicam que o aprendizado das artes deve envolver 
não apenas uma atividade de produção artística pelos alunos, mas também a conquista da significação do que fazem, pelo desenvolvimento da percepção estética, alimentada pelo contato com o fenômeno artístico visto como objeto de cultura através da história e como conjunto organizado de relações formais [BRASIL, 1998, p. 19].

O que se propõe aos educadores e aos educandos é que o conhecimento em Arte e de suas linguagens artísticas "envolve não apenas uma atividade de produção artística pelos alunos, mas também compreender o que fazem e o que os outros fazem" (p. 43), "para tanto, os conteúdos da arte precisam ser transpostos didaticamente de maneira adequada" (p. 44). Desta forma, os PCN-Arte sugerem que o ensino das artes deva acontecer através de atividades que envolvam a produção, a fruição e a contextualização de obras de arte. Segundo este sistema, conhecido como abordagem triangular e desenvolvido pela arte educadora Ana Mae Barbosa, o que se espera do professor de cada uma das quatro linguagens artísticas é que ele conheça sua poética, isto é, seu saber fazer específico, e a sua estética, o saber ler, contextualizando-as em diversas áreas do conhecimento humano, como história, geografia, filosofia, sociologia, antropologia, psicologia e outras mais.

O processo de ensino e aprendizagem das linguagens artísticas, desenvolvidos por intermédio de ações nesses três eixos norteadores, produzir, apreciar e contextualizar, envolve diversos âmbitos de experiência:

- a experiência de fazer formas artísticas incluindo tudo que entra em jogo nessa ação criadora: recursos pessoais, habilidades, pesquisa de materiais e técnicas, a relação entre perceber, imaginar e realizar um trabalho de arte;

- a experiência de fruir formas artísticas, utilizando informações e qualidades perceptivas e imaginativas para estabelecer um contato, uma conversa em que as formas signifiquem coisas diferentes para cada pessoa;

- a experiência de investigar sobre a arte como objeto de conhecimento, no qual importam dados sobre a cultura em que o trabalho artístico foi realizado, a história da arte e os elementos e princípios formais que constituem a produção artística, tanto de artistas quanto dos próprios alunos [p. 36].

Neste projeto pedagógico, o ensino e a aprendizagem em Arte envolvem, portanto, diferentes tipos de ações, que geram diferentes tipos de experiências, possibilitando a produção de conhecimentos, que capacitariam o aluno para ações renovadoras do mundo através das artes. 


\subsubsection{Críticas à formação do professor polivalente}

Os PCN-Arte pretendiam, entre outros objetivos, acabar com o chamado professor polivalente de Educação Artística, formação duramente criticada pelos arte educadores. "Invenção" da ditadura militar para suprir a demanda por professores da "atividade educativa" tratava-se de professores com formação generalista, capacitados em licenciaturas curtas para transitar por várias linguagens artísticas. Assim como os professores que já atuavam na área, e que automaticamente passaram a ser responsáveis pelo ensino de todas as linguagens artísticas, independentemente de suas formações e habilitações, os professores polivalentes tinham "como única alternativa seguir documentos oficiais (guias curriculares) que apresentavam listagens de atividades e livros didáticos em geral, que não explicitavam fundamentos, orientações teórico-metodológicas ou mesmo bibliografias específicas" (p. 27).

A polivalência do professor de Educação Artística é criticada não apenas por seu sistema generalista, no qual dificilmente se consegue formar um educador que domine a produção, a fruição e a contextualização de quatro linguagens artísticas distintas, mas também pela quase impossibilidade de se colocar em prática tal formação. Para Arão Paranaguá de Santana:

Em primeiro lugar, insere-se a negação da polivalência no ensino da Arte e consequentemente a negação da formação do professor-generalista, uma vez que não se tem notícias de boas experiências acerca desse assunto, no Brasil e menos ainda no estrangeiro [SANTANA, 2009, p. 37, grifo do autor].

Ana Mae Barbosa, em 1989, dizia que os professores de arte conseguiam seus diplomas, mas eram "incapazes de prover uma educação artística e estética" que fornecesse "informação histórica, compreensão de uma gramática visual e compreensão do fazer artístico como auto-expressão" (BARBOSA, 1989, p. 181). currículo de Licenciatura em Educação Artística ambicionava preparar um professor de arte em apenas dois anos e que fosse "capaz de lecionar música, teatro, artes visuais, desenho, dança e desenho geométrico, tudo ao mesmo tempo, da $1^{\underline{a}}$ a $8^{\text {a }}$ séries e, em alguns casos, até o $2^{\circ}$ grau" (p. 170). Santana observa que esses cursos de curta duração procuravam atender 
a demanda exigida pelo aumento na oferta de vagas no ensino médio [...]. Associado ao conceito de polivalência instituiu-se o de ciência integrada, arte integrada e outras aberrações epistemológicas, ignorando-se o desenvolvimento histórico peculiar de cada uma dessas áreas do conhecimento [SANTANA, 2009, p. 47, grifos do autor].

Dessa maneira, a Licenciatura em Educação Artística, formadora de professores de arte polivalentes, descaracterizaria o campo de conhecimento autônomo da música, das artes plásticas e das artes cênicas (RIBEIRO apud SANTANA, 2009, p. 84). Mesmo a posterior criação das licenciaturas plenas, que ofereciam mais um ciclo profissionalizante, em geral com um ano e meio de duração, reservado às habilitações em uma única linguagem artística, incorriam no que Santana chama de "aberração epistemológica", pois "essa foi uma solução barata, fácil e sobretudo prática: dois cursos em um, ou seja, a formação plena sobre a curta" (SANTANA, 2009, p. 85, grifo do autor).

Segundo os PCN-Arte, a polivalência fez com que os professores, ao deixarem suas áreas específicas de formação, tentassem "assimilar superficialmente as demais, na ilusão de que as dominariam em seu conjunto" (BRASIL, 1998, p. 27). Essa postura ocasionou

a diminuição qualitativa dos saberes referentes às especificidades de cada uma das formas de arte e, no lugar destas, desenvolveu-se a crença de que o ensino das linguagens artísticas poderia ser reduzido a propostas de atividades variadas que combinassem Artes Plásticas, Música, Teatro e Dança, sem aprofundamento dos saberes referentes a cada uma delas [p. 27].

Reconhecia-se, assim, que as licenciaturas em Educação Artística "não estavam instrumentadas para a formação mais sólida do professor, oferecendo cursos eminentemente técnicos, sem bases conceituais" (p. 27), e a impossibilidade de formação em massa de professores generalistas e polivalentes em artes. Para Vicente Concílio, estas licenciaturas polivalentes não mais se justificariam, "perdendo espaço para licenciaturas que privilegiam a formação artística e a pedagógica, pois é consenso que ambos os aspectos são complementares e de valor equivalente na formação do futuro professor" (CONCíLIO, 2008, p. 73).

A maioria das universidades públicas brasileiras, procurando atender à nova legislação e o que, esperava-se, fosse sua consequente demanda, passa a oferecer 
graduações para a formação de professores especialistas, seja criando licenciaturas, seja adequando as já existentes aos novos Parâmetros. É o caso da Universidade Federal de Alagoas (UFAL), que, em 1981, havia criado o Curso de Artes Cênicas: Interpretação Teatral; substituído, em 1988, pelo Curso Técnico Profissionalizante de Formação do Ator; transformado, dez anos depois, em Curso de Artes Cênicas: Licenciatura em Teatro, já em decorrência da nova legislação educacional brasileira. Posteriormente, em 2006, o curso recebe a denominação de Teatro Licenciatura e, a partir dele, é criado o Curso de Dança Licenciatura (UFAL, 2014, p. 15).

Ao adequarem-se à legislação através das licenciaturas específicas em Teatro, Dança, Música e Artes Visuais, as universidades públicas brasileiras vêm sepultando a antiga formação polivalente, porém não sua presença na Educação Básica.

\subsubsection{Questões legais e trabalhistas}

Anteriormente, foi citada uma afirmação dos gestores da Secretaria de Estado da Educação de Alagoas (SEE), realizada durante o processo de construção dos Referenciais Curriculares para a Educação Básica daquele estado, que a presença das quatro linguagens artísticas da disciplina Arte (Teatro, Dança, Música e Artes Visuais) fazia parte dos "direitos de aprendizagem do aluno", e, desta forma, esses componentes curriculares teriam que ser ministrados, seja qual fosse a habilitação dos professores. A afirmação, já criticada por seu posicionamento ético, será retomada aqui para se problematizar alguns aspectos legais e trabalhistas do exercício profissional do Professor de Teatro.

Se aqueles seriam direitos do aluno, quais seriam, então, os direitos do profissional que foi habilitado em uma formação artístico-pedagógica e que, mesmo assim, deve ministrar aulas de componentes curriculares para os quais não teve formação? Ainda que as questões trabalhistas não sejam o foco desta pesquisa, vale citar Vicente Concílio ao observar que "a necessidade de reconhecimento e valorização da categoria e dos resultados de seu trabalho por camadas mais amplas 
da sociedade civil e dos órgãos governamentais de toda ordem" (CONCÍLIO, 2008, p. 72) são essenciais para a efetiva legitimação de Arte como área de conhecimento escolar. Regileno Lima, através da análise dos Projetos Pedagógicos das cinco escolas particulares por ele pesquisadas, constatou que em apenas uma delas segue-se à risca o que determina a LDB de 1996: "Na contramão dessa realidade, $80 \%$ das escolas investigadas tentam mascarar criando artifícios de burla para infringir o que determina a lei" (LIMA, 2012, p. 88).

Os artifícios de burla a que se refere o pesquisador vão desde a não inclusão de Arte como disciplina obrigatória nos Projetos Pedagógicos e na matriz curricular da escola, até a contratação de professores sem formação específica nas quatro linguagens artísticas indicadas pelos PCN-Arte. Na maior parte dos casos, as aulas de Arte dessas instituições particulares restringem-se a atividades extracurriculares, prática semelhante encontrada também em algumas escolas públicas de Alagoas, como se pode ler na monografia de Jocianny Carvalho (2014), Maresiando no colaborativo: o processo colaborativo como prática pedagógica, apresentada como TCC de Teatro Licenciatura, na UFAL. A autora analisa projeto teatral extracurricular desenvolvido a pedido do diretor de uma escola pública de Maceió, na qual realizava estágio. Tratava-se de uma forma de avaliação para o Ensino Fundamental II, "já que os alunos do [período] vespertino não tiveram aula de arte durante o ano letivo" (CARVALHO, 2014, p. 13). O que se entende no decorrer do texto é que simplesmente não existia na escola Professor de Arte durante todo o período letivo anual. Com a necessidade de resolver "legalmente" a questão da avaliação dos alunos na disciplina, o diretor simplesmente elegeu para tal fim um projeto extracurricular coordenado por uma estagiária. Fica claro que os conteúdos, a abordagem pedagógica e os componentes curriculares indicados nos PCN-Arte foram ignorados, infringindo os "direitos de aprendizagem dos alunos", o que talvez não ocorresse caso a Secretaria de Educação cumprisse com sua obrigação e contratasse um Professor de Arte. Ou seja, como escreveu Regileno Lima, criou-se outro artifício de burla para infringir o que determina a lei.

As burlas à lei para driblar a necessária contratação de professores de Arte são recorrentes, como se pôde constatar nos sessenta e dois (62) Relatórios de Estágio pesquisados. Em aproximadamente um terço das instituições de ensino não 
havia professores habilitados em Arte, pois em oito escolas as aulas de Arte eram ministradas por professores sem graduação específica, e em doze, não havia nenhum professor responsável pela disciplina. Dessas doze escolas, bolsistas do PIBID (Programa Institucional de Bolsas de Iniciação à Docência, do MEC) ministravam as aulas de Arte em duas delas; em cinco, os professores responsáveis eram monitores ${ }^{13}$; nas cinco restantes, os próprios estagiários assumiram a disciplina.

A situação é descrita de maneira irônica por um estagiário:

Há uma peculiaridade em relação ao narrador-estagiário que em algumas vezes atuará como único ministrador de aulas em Arte, sobretudo no primeiro semestre do ano de 2012, pois a referida escola não possuía, em seu quadro docente, um ou uma profissional formado ou apto nesta disciplina e encontrou no narrador-estagiário a saída para o preenchimento da lacuna. A Escola de Ensino Fundamental X., apenas no início de abril é que pode contar com a colaboração da monitora [...], encaminhada pela Secretaria Municipal de Educação, dentro dos trâmites exigidos por Lei que regem a Educação no Brasil [Relatório de Estágio].

A forma de preservar os "direitos de aprendizagem do aluno" diante da ausência do Professor de Arte é colocar o estagiário para ministrar as aulas da disciplina e, mais uma vez, burla-se a lei. O Estágio Curricular Supervisionado tem como objetivo aproximar o futuro professor das práticas didático-pedagógicas no campo de sua atuação profissional, "propiciando aos estudantes a vivência no ambiente escolar" (UFAL, 2014, p. 138), sob as supervisões de um Professor Orientador, do curso de origem, e de um Professor de Arte, no local do estágio. Talvez fosse desnecessário descrever esse componente curricular, obrigatório em todas as licenciaturas do país, caso não fosse recorrente nas escolas de Alagoas o "uso" ilegal de estagiários como substitutos de professores ausentes.

Note-se que o "preenchimento da lacuna" foi, em seguida, realizado através do encaminhamento de uma monitora pela Secretaria Municipal de Educação de Maceió. Edilene B. da Silva (2013) relata, em seu TCC, como foi sua contratação nesta função:

${ }^{13}$ Estudantes de graduações em licenciaturas contratados pela Secretaria de Estado da Educação (SEE) e pela Secretaria Municipal de Educação de Maceió (SEMED) como professores substitutos. 
No ano de 2012, eu participei do concurso seletivo para o cargo de professor monitor da rede estadual de ensino do estado de Alagoas. Fui convocada no ano de 2013 e assumi a sala de aula, não somente a sala de aula, mas as salas de aula, foram 22 (vinte e duas) turmas (SILVA, 2013, p. 50).

Entende-se como monitor aquele estudante de licenciatura que tenha cumprido no mínimo $50 \%$ das disciplinas do curso para atuar como professor substituto na rede pública de ensino alagoana, recebendo, para isso, uma remuneração mensal através de um contrato de trabalho temporário. Os estágios supervisionados também são realizados somente na segunda metade do curso, o que faz com que o estagiário e o monitor, na maioria das vezes, possuam experiências similares no exercício da docência. Também é comum, na licenciatura em Teatro da UFAL, a presença de estudantes como monitores em uma escola e como estagiários em outra. Para Manuella de Oliveira e Laura Pizzi (2012), "trata-se de uma estratégia largamente utilizada para suprir a carência de professores na rede pública de ensino fundamental do Estado de Alagoas", utilizada há mais de duas décadas. As autoras afirmam que a "política de substituição de contratação de seu quadro de docentes via concurso público, pelo contrato temporário de professores" (2012), é um dos fatores para a precarização do trabalho docente no estado. Porém, como se lê ironicamente no relato do estagiário acima, monitores são contratados "dentro dos trâmites exigidos por Lei que regem a Educação no Brasil", pelas duas secretarias de educação que atuam no sistema educacional público de Maceió, a municipal e a estadual, para ministrarem aulas de Arte. Desta forma, burla-se a lei ao não se contratar profissionais formados e habilitados, usando-se como artifício uma prática considerada "normal", ainda que contestada.

Outro Relatório de Estágio mostra como essa prática está "naturalizada" em Alagoas, através da descrição das atividades profissionais de um professor de Arte "titular":

Ele é o único professor [de Arte] da escola, tendo que se desdobrar nos três horários, mesmo não sendo efetivo e sim monitor, ele já está na escola [Estadual] a mais de três anos, e também leciona em outras instituições públicas e privadas [Relatório de Estágio].

A contratação de monitores para ministrar aulas de Arte nas redes públicas de ensino de Maceió e Alagoas transformou-se em meio de sobrevivência para os 
estudantes de licenciatura, como se percebe pelo tempo em que o professor/monitor leciona na rede estadual, três anos. Não são poucos os alunos que prorrogam indeterminadamente a entrega de seus TCC para não completarem a graduação na licenciatura em Teatro da UFAL e, assim, poderem continuar a exercer as atividades de monitoria, sendo, portanto, remunerados. Para os estudantes com necessidades financeiras é preferível receber um salário menor de monitor a não receber como professor, pois o estado e os municípios não contratam professores de Arte, ou, quando contratam, oferecem poucas vagas nos raros concursos públicos. Para as secretarias de educação é mais econômico pagar o salário de um monitor do que o de um professor e, em caso de greve, é mais fácil coagir um trabalhador com contrato temporário do que um efetivado. Como estas lógicas estão disseminadas no Ensino Superior alagoano e nas secretarias de educação do estado, não surpreende a última colocação de Alagoas no IDEB.

Os concursos públicos em Alagoas, em geral, reservam poucas vagas para a formação genérica "Professor de Arte", sendo praticamente inexistente a oferta para professores de Teatro, Dança, Música e Artes Visuais. Em anos passados, os professores habilitados nessas linguagens e aprovados em concursos da Secretaria de Educação do Estado (SEE) tiveram que entrar com ações judiciais para garantir seus direitos, visto que aquele órgão governamental não aceitava as habilitações específicas para o cargo de Professor de Arte.

Tais situações não são exclusivas de Alagoas pois ocorrem em todo território nacional, como se pode ver na Carta aberta aos governos e gestores educacionais dos docentes das licenciaturas em Dança e em Teatro do Brasil ${ }^{14}$. Neste abaixoassinado reivindica-se "a realização de concursos públicos que contemplem as diversas formações em Arte", sob o argumento de que

há um número grande de licenciados egressos das diversas áreas da Arte que enfrentam dificuldade para assumirem seu lugar de direito nessa disciplina nas escolas de educação básica das redes públicas municipais, estaduais e federal em decorrência de editais mal elaborados, que não contemplam as licenciaturas em teatro e dança ou que simplesmente ignoram que teatro e dança são formações docentes legítimas. O mesmo acontece nas redes privadas de ensino, que muitas vezes desconsideram a existência destes profissionais em suas seleções e currículos [Anexo A].

\footnotetext{
${ }^{14}$ Ver nota 8.
} 
Justificava-se a proposição deste abaixo-assinado diante de dois exemplos recentes acontecidos em São Luís (MA) e Santa Maria (RS), "somente para citar a 'amplitude geocultural' alcançada pelo problema" (Anexo A), nos quais egressos de licenciatura em Teatro foram impedidos de participar em concursos públicos para professores da Educação Básica nestas cidades. O direito a ocupar os espaços legítimos de ensino da Dança, Teatro e Artes Cênicas, que possuem os profissionais formados nessas licenciaturas, vem sendo conquistado, muitas vezes, através da "abertura de processos para que suas admissões sejam garantidas em cumprimento de decisão judicial" (Anexo A), tal como relatamos ter ocorrido em Alagoas.

As docentes propositoras da carta entendem que

é responsabilidade do Estado pôr em prática diretrizes das políticas educacionais que atendam de forma eficaz às necessidades da educação, garantindo a abertura de vagas e admissão através de concursos públicos para professores habilitados nos cursos de Licenciatura em Teatro, Licenciatura em Dança e Licenciatura em Artes Cênicas, assim como em Música e Artes Visuais [Anexo A].

Desta forma, cento e noventa e quatro (194) professores e professoras dos cursos de Artes Cênicas, Licenciaturas em Teatro e Licenciaturas em Dança do país subscreveram a carta ${ }^{15}$, reivindicando aos gestores e autoridades de secretarias de educação municipais, estaduais e federal que deixem de realizar concursos de caráter genérico na área de Arte, nos quais se desconsideram as formações específicas, e respeitem a formação universitária dos egressos dessas licenciaturas, isto é, "a docência em teatro e dança na educação básica".

Nas questões legais e trabalhistas, o que estabelece a lei é uma coisa e a realidade do sistema educacional brasileiro é outra. Se os PCN-Arte são claros sobre a necessidade de professores especializados em cada uma das linguagens artísticas, não só as instituições escolares do país não se adequaram a eles, como também não o fizeram as instâncias gestoras da educação escolar. Mais de quinze anos depois de publicados, o quadro possui as mesmas características quando da implantação dos PCN-Arte, o que os coloca na mesma categoria das leis que "não pegaram". A luta de anos dos arte educadores brasileiros, aparentemente ganha nos

${ }^{15}$ Conforme mensagem eletrônica recebida em 27 de março de 2015. 
documentos oficiais, é perdida na realidade escolar. A combatida e rechaçada polivalência continua como a solução possível para respeitar o "direito de aprendizado dos alunos", ainda que desrespeitem os direitos de trabalho dos professores de Arte.

\subsubsection{Os PCN-Arte e a escola de tempo integral}

A pedra encontrada no meio do caminho entre a formação do Professor de Teatro na universidade e as condições de trabalho encontradas na Educação Básica tem se transformado com o passar dos tempos. Ventos e chuvas, como a citada Carta aberta dos professores de licenciatura e a proposta de uma nova BNCC, por exemplo, podem ir desbastando e aparando suas arestas mais proeminentes, mas outros elementos animais e vegetais vão se mineralizando nela, mudando aos poucos sua constituição e seus contornos. Se o que se apresentava como um ideal possível para o ensino de Arte na escola, no final do século XX, foi, de certa forma e em alguns aspectos, incorporado aos documentos oficiais, talvez seja necessário reavaliar esses ideais não somente diante dos embates com a realidade imediata, mas também frente às perspectivas de mudanças no sistema educacional brasileiro.

Mudanças que estão projetadas a partir da Lei № 13.005, de 2014, que, em seu artigo 1a, aprova o Plano Nacional de Educação - PNE. O novo PNE possui 20 metas a serem atingidas durante sua vigência, nos próximos dez anos, das quais, destaca-se, para este estudo, a sexta, ou seja, "oferecer educação em tempo integral em, no mínimo, 50\% (cinquenta por cento) das escolas públicas, de forma a atender, pelo menos, $25 \%$ (vinte e cinco por cento) dos(as) alunos(as) da educação básica" (BRASIL, 2014).

A educação em tempo integral é tida como remédio para vários males que afligem o país, desde a redução da violência urbana à reversão do baixo crescimento econômico dos últimos anos; da confirmação do Brasil como potência olímpica à melhoria nos índices de saúde da população. Talvez também se encontre nela a panaceia para a implantação efetiva dos PCN-Arte, através da criação das 
condições necessárias para a efetivação do ensino das quatro linguagens artísticas ministradas por professores especialistas, na Educação Básica.

As expectativas para que essas mudanças realmente aconteçam podem estar em cinco das nove estratégias traçadas pela Lei para alcançar esta Meta 6. São elas:

6.1) promover, com o apoio da União, a oferta de educação básica pública em tempo integral, por meio de atividades de acompanhamento pedagógico e multidisciplinares, inclusive culturais e esportivas, de forma que o tempo de permanência dos (as) alunos (as) na escola, ou sob sua responsabilidade, passe a ser igual ou superior a 7 (sete) horas diárias durante todo o ano letivo, com a ampliação progressiva da jornada de professores em uma única escola;

6.2) instituir, em regime de colaboração, programa de construção de escolas com padrão arquitetônico e de mobiliário adequado para atendimento em tempo integral, prioritariamente em comunidades pobres ou com crianças em situação de vulnerabilidade social;

6.3) institucionalizar e manter, em regime de colaboração, programa nacional de ampliação e reestruturação das escolas públicas, por meio da instalação de quadras poliesportivas, laboratórios, inclusive de informática, espaços para atividades culturais, bibliotecas, auditórios, cozinhas, refeitórios, banheiros e outros equipamentos, bem como da produção de material didático e da formação de recursos humanos para a educação em tempo integral;

6.4) fomentar a articulação da escola com os diferentes espaços educativos, culturais e esportivos e com equipamentos públicos, como centros comunitários, bibliotecas, praças, parques, museus, teatros, cinemas e planetários;

$[\ldots]$

6.9) adotar medidas para otimizar o tempo de permanência dos alunos na escola, direcionando a expansão da jornada para o efetivo trabalho escolar, combinado com atividades recreativas, esportivas e culturais [grifos nossos].

Vê-se que as atividades culturais, ao lado das esportivas, recebem destaque dentre aquelas que farão parte das estratégias para ampliar o tempo de permanência dos alunos na escola, inseridas como "atividades de acompanhamento pedagógico e multidisciplinares". Ao lado da "ampliação progressiva da jornada de professores em uma única escola", da reestruturação da arquitetura escolar, adequando-a para receber essas atividades, e da abertura de canais de diálogo com os setores culturais presentes na comunidade através da articulação com espaços e equipamentos públicos, espera-se que essas atividades fomentem a vida cultural dos alunos e influam decisivamente na melhoria do sistema escolar brasileiro como um todo. 
Aqui cabem algumas conjecturas que talvez sirvam como possibilidades de reflexão sobre o que os professores de Teatro da Educação Básica e os docentes formadores do Ensino Superior realmente querem e pretendem com o ensino de Teatro dentro das escolas.

A se entender que atividades culturais referem-se aos componentes curriculares obrigatórios de Arte, os problemas colocados até aqui como o pouco tempo de aula voltado às atividades artísticas e os espaços inadequados para sua realização, e mesmo os que ainda não foram citados, como o excesso de deslocamentos dos professores entre as inúmeras escolas em que trabalham e a dificuldade em estabelecer canais de diálogo com a produção cultural das cidades, poderão ser minimizados e, se possível, suplantados para que os PCN-Arte deixem de ser somente a troca de nomenclatura das matérias voltadas ao ensino das artes nas escolas.

Por outro lado, se atividades culturais forem entendidas de uma maneira mais ampla e flexível, sem que estejam, necessariamente, ligadas à disciplina Arte, será outra a perspectiva para as artes dentro das escolas. Talvez se possam ter, no chamado contra turno, atividades artístico-culturais optativas, como acontece nas escolas de tempo integral de outros países, como, por exemplo, o Japão. Aulas, cursos e a formação de grupos voltados à linguagem teatral, à dança, à música, e também ao cinema, à literatura e a tantas outras formas de manifestação artística poderão ser realizados, junto com a contratação de professores especializados. Sendo assim, a formação do Professor de Teatro poderia estar mais próxima daquela aludida no início deste capítulo, ou seja, voltada a atividades extracurriculares e com caráter de ação sociocultural. Desta forma, as atividades culturais, ao não se caracterizarem como curriculares e obrigatórias, talvez voltem, ironicamente, a ser vistas como educativas, tal qual na antiga Educação Artística, porém, sem a presença daquele professor polivalente.

No caso dessas atividades serem educativas e de apoio pedagógico, com caráter de ação sociocultural, a disciplina Arte continuaria sendo obrigatória e oferecida no turno das atividades curriculares? Isabel Marques e Fábio Brazil, ainda que não considerem a futura escola de tempo integral em suas reflexões, defendem a necessidade da Arte curricularizada na escola argumentando que "as diversas 
leituras de mundo via diferentes linguagens [...] possibilitam conhecer, reconhecer, ressignificar e, sobretudo, impregnar de sentidos a vida em sociedade" (2014, p. 30), em sendo assim, "ampliar o conhecimento e a consciência sobre as diversas linguagens artísticas é possibilitar aos estudantes que atuem na construção, e não na reprodução ingênua, dos valores sociais" (p. 38).

Ora, em se mantendo o ensino curricularizado das artes, talvez seja necessário rever algumas das indicações dos PCN de maneira que enfrentem efetivamente alguns dos problemas levantados pelos estagiários da UFAL, como a produção de materiais didáticos específicos e a construção de um currículo seriado nacional comum que explicite minimamente conteúdos, práticas e linguagens artísticas a serem abordadas em cada ano letivo.

E qual é a resposta que os professores de Teatro querem para esta questão? É desejo dos professores de Arte e de Teatro que a curricularização da disciplina ocorra nos moldes instituídos para as demais disciplinas presentes na Educação Básica? Ao se adotar materiais didáticos e conteúdos seriados obrigatórios, seja no âmbito regional, seja nacional, não se estaria tirando um espaço de liberdade com o qual sempre sonharam os professores de Arte, os arte educadores, os artistas docentes, ou seja lá em qual denominação gostaríamos de nos reconhecer? Esta liberdade de ação e de criação não é justamente a que se anseia para a realização plena do aprendizado artístico e estético nas escolas? É a pergunta que se faz Suzana Saldanha, ainda que ao se referir à inclusão da antiga "atividade educativa" Educação Artística na escola:

É com a inclusão da Educação Artística - música, teatro e artes plásticas - nos currículos de $1^{\circ}$ e $2^{\circ}$ graus em 1971, com a Lei 5692, que se cria (penso eu) um impasse:

a) O primeiro sentimento é de felicidade: afinal a lei chegava para legitimar uma disciplina, e um professor que trabalhava quase na clandestinidade;

b) o segundo sentimento, para os que pensam na educação, é de pânico: as artes iam entrar no currículo escolar e haveria um programa a ser cumprido - e é bom que não nos esqueçamos de que estávamos vivendo sob uma ditadura militar. Pouco a pouco iria desaparecer aquele "louco" (como carinhosamente chamo os professores pioneiros que se aventuravam a trabalhar com as artes em geral e principalmente 0 teatro) que vislumbrava na arte teatral a essência da linguagem do teatro e não só um meio de expressão natural que desenvolve habilidades [SALDANHA, 2003, p.125]. 
O que Suzana Saldanha coloca como um impasse talvez seja o grande paradoxo que os professores de Teatro terão que enfrentar, mas que parecem se recusar a fazê-lo, pois se deseja a escolarização das artes, mas negam-se a função social e as formas de funcionamento da escola; denuncia-se nos discursos de diretores, de gestores e da comunidade escolar em geral a incompreensão da arte como campo de conhecimento, mas não se reconhece nossa própria incompreensão do sentido da escola.

Daqui a alguns anos não seria surpresa encontrar a pedra, ainda que transformada pelo tempo, no mesmo lugar, no meio do caminho entre a formação idealizada de professores de Teatro e a escola real. Ou, quem sabe, a atual situação vire somente uma lembrança em nossas retinas. 


\section{2 \\ ARTE E ESCOLA: \\ CONVERSAS NÃO CONVERSADAS}

Conversas não conversadas

Pesam sobre o braço que empunha a espada

Discordância encoberta

Tornam as fileiras de combate inseguras

Heiner Müller 
A inserção do teatro e das artes no currículo da Educação Básica parece ter uma ampla aceitação na sociedade brasileira, ainda que não se possa afirmar que haja unanimidade sobre o tema. É o que se percebe através de documentos educacionais, publicações as mais diversas (acadêmicas, jornais, revistas, fóruns em redes sociais digitais etc.), falas e discursos oriundos de diversos setores que defendem o aprendizado das linguagens artísticas como um direito do cidadão e uma espécie de capacitação para o exercício da cidadania. Educadores e gestores escolares defendem e democratização no acesso a esse patrimônio cultural humano, seja através do reconhecimento e estudo de obras artísticas consideradas relevantes, seja como exercício de linguagem. Arte educadores defendem que o aprendizado das linguagens artísticas são imprescindíveis para a formação do sujeito emancipado e autônomo diante do mundo. Artistas acreditam na potência transformadora que a arte possui e que a própria escola necessitaria. Não se pode afirmar, porém, que esses posicionamentos se constituam como identidades dos setores citados, pois se percebe que existe uma espécie de trânsito dessas opiniões entre os diversos grupos sociais, gerando uma pluralidade interna de opiniões, bem como, por vezes, a recusa ao posicionamento dos próprios pares. Em sendo assim, por que ainda estamos longe da legitimação da arte como área de conhecimento escolar como foi problematizado no capítulo anterior?

O que se percebe é que existe uma multiplicidade de sentidos e compreensões sobre a escola e sobre a arte e que por vezes são conflitantes. As divergências muitas vezes são omitidas ou minimizadas publicamente em nome de um suposto consenso, que se encontra, talvez, muito mais nos desejos e nas ideias do que nas ações e na realidade escolar. Mesmo quando as discordâncias não estão encobertas transformam-se em conversas mal conversadas, diálogos de surdos nos quais os interesses corporativos em defesa de perspectivas que se querem únicas embrutecem a escuta.

Diversos relatos de estudantes apresentados no primeiro capítulo poderiam servir como exemplos para essa situação, porém um acontecimento vivido pelos professores do Colegiado de Teatro da UFAL e os Técnicos Educacionais da Próreitoria de Graduação (Prograd), desta universidade, pode revelar um dos aspectos dessas discordâncias. Quando da realização do novo Projeto Pedagógico do Curso 
(PPC) de Teatro Licenciatura, em 2014 - sobre o qual se discorrerá mais a frente -, os técnicos da Prograd estranharam o uso do termo "pedagogo teatral" em diversas passagens do documento então em construção. Segundo eles, a qualificação "pedagogo" só poderia ser utilizada por formados em faculdades e institutos de Educação, o que causou estranheza, desta vez, no Colegiado de Teatro. Para nós, artistas e pesquisadores da linguagem teatral, o termo "pedagogo teatral" vem sendo cada vez mais empregado, pois entendemos que os materiais de estudo bem como os processos de aprendizagem da linguagem teatral possuem especificidades e singularidades para as quais o uso do adjetivo delimitaria com mais precisão as fronteiras desse campo do conhecimento. Em publicação da Associação Brasileira de Pesquisa e Pós-Graduação em Artes Cênicas (ABRACE), Ingrid Koudela e Arão Paranaguá de Santana procuram delimitar a área de interesse da Pedagogia do Teatro, na perspectiva do Grupo de Trabalho Pedagogia do Teatro \& Teatro e Educação dessa associação, como aquela que "incorpora tanto a investigação sobre a teoria e prática da linguagem artística do teatro quanto sua inserção nos vários níveis e modalidades de ensino" (KOUDELA e SANTANA, 2006, p. 73). Esses autores enfatizam, como áreas de pesquisa da pedagogia teatral, o jogo teatral, o teatro como ação cultural, a formação do professor e a recepção de espetáculos teatrais.

Parecia-nos que os técnicos educacionais da Prograd, todos eles formados em Educação, queriam se apropriar da Pedagogia de maneira exclusiva. Em nome da urgência na aprovação do novo PPC a conversa mal conversada prevaleceu, os ouvidos se fizeram moucos mais uma vez e a maioria das passagens que continha o termo em discussão teve que ser reescrita, trocando-se "pedagogo" por "professor" ou "educador".

A situação relatada pode estar restrita ao contexto universitário em que os acontecimentos se desenrolaram, porém, pode também exemplificar o que já se suspeitava através das pesquisas desenvolvidas para esta tese. Talvez exista uma espécie de antagonismo entre, de um lado, a comunidade escolar, que ainda parece desprezar e deslegitimar as formas de conhecimento de mundo e de modalidades pedagógicas intrínsecas às artes, e, de outro, os arte educadores, que insistem em desqualificar o sentido e a função da escola, negando suas formas de organização e 
modos pedagógicos. Cada lado parece possuir opiniões fechadas sobre o que é a arte e o que é a escola. Capazes de falar e expor suas visões parecem incapazes de ouvir o outro.

A provável incapacidade de escuta de ambos os lados pode encobrir questões que vão além dos exemplos apresentados no primeiro capítulo, pois estes tendem a ver o problema no outro, quando seria preciso ver com os olhos do outro. A necessidade de se estabelecer um diálogo entre esses dois campos do saber, a arte e a escola, passa pela análise de algumas questões que o presente capítulo irá desenvolver e verificar, como: as diferenças entre suas formas de produção do conhecimento; sobre a multiplicidade de sentidos, funções e objetivos que tanto a arte como a escola podem assumir; as expectativas que a sociedade possui desses campos do conhecimento e que, talvez, não possam ser cumpridas por eles; e as perspectivas daqueles que sofrem com essa dificuldade de comunicação, isto é, os estudantes da Educação Básica.

\subsection{Arte, escola e suas diferentes formas de operar o conhecimento.}

Os PCN-Arte, vistos como um ideal possível para o atual contexto educacional brasileiro, enfrentam dificuldades para sua plena implantação devido aos desencontros entre suas proposições e a realidade escolar alagoana, como se procurou mostrar no primeiro capítulo deste trabalho. Em várias passagens aventouse a hipótese de que o problema poderia estar além das situações relatadas pelos estudantes de Teatro Licenciatura da UFAL, as quais, em geral, revelavam o desconhecimento ou o descumprimento da lei e indicavam a dificuldade dos PCNArte em se adequarem aos múltiplos contextos escolares do Brasil. A hipótese é a de que existe uma incompreensão quanto ao sentido da arte por parte da comunidade escolar e, do mesmo modo, uma incompreensão do sentido e da função da escola por parte dos professores de Arte, arte educadores, docentes artistas, formadores de professores e pesquisadores acadêmicos. Caso esta hipótese seja plausível, a questão seria a de se entender se tais incompreensões podem ser solucionadas ou se elas são a expressão de uma situação incontornável, 
isto é, que o sentido da escola formal e o sentido do ensino das artes seriam excludentes. Colocando de outra maneira: seriam contornáveis e transponíveis as diferenças entre os objetivos e os procedimentos pedagógicos da escola e da arte, sem que se comprometa a potência de transformação de mundo que ambas possuem?

A pesquisa exposta mostrou em diversas passagens que o sistema educacional formal e a comunidade escolar (gestores, professores, pais, alunos e funcionários) possuem uma dificuldade arraigada historicamente em reconhecer na arte uma forma singular de se pensar o mundo e, por conseguinte, entender que suas práticas pedagógicas são diferenciadas em relação às demais disciplinas, voltadas aos conhecimentos filosóficos e científicos. Por outro lado, também observamos que os professores de Arte apresentam uma dificuldade em lidar com as estruturas do ensino formal, como a pequena duração das aulas, o espaço físico e o mobiliário das salas, a necessidade de planejamento e a avaliação por meio de notas, a importância de se estabelecer uma base curricular comum nacional, a falta de materiais didáticos e, principalmente, com o conceito de "saber escolar", no qual o conhecimento produzido pela humanidade em diversas áreas se modifica ao ser transposto para a escola. Isabel Marques e Fábio Brazil assim expõem esse desencontro:

O ensino de Arte nas escolas vive sobre um terreno perigoso e movediço. O que caracteriza a escola formal tradicional não diz respeito ao universo da arte; o que caracteriza o fazer/pensar da arte é muitas vezes estranho ao mundo escolar. Regra e criação, tradição e invenção, burocracia e transformação, resultados numéricos e possibilidades de sentido podem conviver num mesmo espaço? [MARQUES e BRAZIL, 2014, p. 44].

Neste contexto, se a entrada das artes no currículo escolar foi uma conquista dos arte educadores, também provocou aquele sentimento de pânico relatado por Suzana Saldanha, pois "haveria um programa a ser cumprido", o que poderia provocar o desaparecimento daquele professor "louco" (SALDANHA, 2013, p. 125) e de suas formas de ensino e aprendizagem que não se enquadravam na estrutura escolar. Marques e Brazil afirmam que, em muitos casos, houve mesmo uma espécie de "enjaulamento da própria arte. [...] Em algumas escolas a arte perdeu 
não somente seu status, seu prazer ou gostosura, mas perdeu também seu potencial transformador" (MARQUES e BRAZIL, 2014, p. 79):

Tradicionalmente, reza o senso comum, o "artista" tem o papel de criar, descobrir, inventar, transformar, transgredir, articular, inovar, imaginar e sonhar; mas do professor, o senso comum espera que sistematize, estabeleça processos de ensino e aprendizagem, delineie e persiga objetivos claros, escolha metodologias teoricamente sustentáveis e avalie objetivamente os resultados produzidos pelos estudantes [p. 44].

Ou seja, havia, e ainda há, um sentimento de temor nos arte educadores de que se a arte se adequar às estruturas do sistema escolar perderá sua capacidade de transgressão e crítica, críticas dirigidas até mesmo à própria escola e aos seus modelos pedagógicos. Temor que pode ser resumido no questionamento que fazem Marques e Brazil ao se colocarem o porquê de se "trabalhar com estudantes tradicionais, cansativos, desgastantes. [...] Seria porque optamos por 'escolarizar' a arte em vez de vivenciá-la com os estudantes?" (p. 44). Algumas questões nos parecem extremamente necessárias diante dessas perguntas: por que estudantes "tradicionais" são cansativos e desgastantes? Qual o entendimento que se tem de escola e de educação tradicional que embase essa colocação? A hipótese levantada pelos autores, a da "escolarização" como causa, pode nos conduzir a uma série de problematizações a partir de algumas de suas interfaces. Será que nós, arte educadores, estamos realmente "escolarizando" a arte ou, pelo contrário, resistimos a esse processo e, assim, deixamos de nos inserir nas formas de legitimação próprias à escola? E se estamos "escolarizando" a arte, de que forma se realiza esse processo que faz com que vejamos no outro, nos estudantes, a causa de nosso cansaço e desgaste? A dissociação que os autores fazem entre "escolarização" e "vivência da arte" como processos de aprendizagem indica outros possíveis questionamentos: o que se entende por "escolarização e "vivência"? As duas são, necessariamente, excludentes? "Escolarização" deve ser entendida por um viés redutor? A "vivência da arte" seria a forma mais apropriada para o aprendizado de uma linguagem artística no contexto da Educação Básica?

O que transparece na pergunta, entretanto, é que existe um temor ainda maior, o de que essas dificuldades de reconhecimento de alteridades e de compreensão do outro revelem que as formas diferenciadas de construção e 
transmissão desses campos de conhecimento façam parte de projetos pedagógicos distintos e, talvez, inconciliáveis.

\subsubsection{Conhecimento escolar e conhecimento da arte: fricções}

Os Parâmetros Curriculares Nacionais equiparam a arte à ciência ao afirmar que ambas procuram compreender o lugar do ser humano no universo, em busca da significação da vida:

Tanto a ciência quanto a arte, respondem a essa necessidade mediante a construção de objetos de conhecimento que, juntamente com as relações sociais, políticas e econômicas, sistemas filosóficos e éticos, formam o conjunto de manifestações simbólicas de uma determinada cultura. Ciência e arte são, assim, produtos que expressam as representações imaginárias das distintas culturas, que se renovam através dos tempos, construindo o percurso da história humana [BRASIL, 1998, p. 26].

O pensamento de Gilles Deleuze e Felix Guattari possui perspectiva semelhante à apresentada nos $\mathrm{PCN}$, pois reconhece na ciência, na arte e na filosofia formas legítimas de pensamento e de criação. Em $O$ que é a filosofia? (1992), esses filósofos franceses afirmam que para se produzir pensamento é preciso enfrentar o caos, traçando um plano sobre ele, pois como um lugar do pensamento não pensado, um território infinito de velocidades infinitas, o caos se caracteriza como uma zona de potencialidades. Pensar é criar formas, forças e funções diferenciadas, as Caóides, isto é, a arte, a filosofia e a ciência, "realidades produzidas em planos que recortam o caos" (DELEUZE e GUATTARI, 1992, p. 267).

Das frases ou de um equivalente, a filosofia tira conceitos (que não se confundem com ideias gerais ou abstratas), enquanto que a ciência tira prospectos (proposições que não se confundem com juízos), e a arte tira perceptos e afectos (que também não se confundem com percepções ou sentimentos) [p.37, grifos dos autores].

Operando no plano de imanência, que "envolve movimentos infinitos que o percorrem e retornam" (p. 51), a filosofia procura guardar as velocidades infinitas, selecionando "movimentos infinitos do pensamento" (p. 154) e criando conceitos. Já o pensamento científico opera no caos em um plano de referência. Ao traçar limites 
e bordas, a ciência renuncia ao infinito, à velocidade infinita, como uma "parada da imagem", em uma "fantástica desaceleração" (p.154).

Para Deleuze e Guattari, a arte, por sua vez, "quer criar um finito que restitua o infinito" (p. 253), pois o pensamento artístico opera no caos em um plano de composição, emoldurando-o, sem mexer em suas velocidades infinitas. "A arte não é o caos, mas uma composição do caos, que dá a visão ou sensação, de modo que constitui um caosmos, como diz Joyce, um caos composto - não previsto nem preconcebido" (p. 263).

O que esses filósofos nos apresentam são modos distintos de pensar e de criar (que, para eles, são a mesma coisa), sem hierarquias, pois "pensar é pensar por conceitos, ou então por funções, ou ainda por sensações, e um desses pensamentos não é melhor que outro, ou mais plenamente, mais completamente, mais sinteticamente "pensado"' (p. 253). Assim, nestas justificativas, as verdades da arte não são menos verdadeiras que as da filosofia e da ciência, e "seus objetos não estão limitados ao domínio da vivência subjetiva do artista", como afirma Alberto Gualandi ao se referir ao pensamento de Deleuze (GUALANDI, 2003, p. 102).

Como lembram Deleuze e Guattari, os pensamentos já pensados tendem a se estratificar e são os novos pensamentos que irão criar fissuras nesses estratos, linhas de fuga no conhecimento já adquirido. Assim, pensar não significa criação consensual sob a égide de uma autoridade, de um Estado ou de instituições, pelo contrário, pois, para Deleuze, segundo Gualandi, "toda disciplina criadora pode criar apenas em ruptura com o senso comum, o bom senso ou a opinião (mundo da representação), em ruptura com as formas universalmente divididas de intersubjetividade" (p. 99). Ou seja, nesta perspectiva podemos chamar de cultura todo pensamento estratificado e consensual sobre o qual a arte agiria em dissenso e ruptura, rasgando o conhecimento que se estratificou:

Num texto violentamente poético, Lawrence descreve o que a poesia faz: os homens não deixam de fabricar um guarda-sol que os abriga, por baixo do qual traçam um firmamento e escrevem suas convenções, suas opiniões; mas o poeta, o artista abre uma fenda no guarda-sol, rasga até o firmamento, para fazer passar um pouco do caos livre e tempestuoso e enquadrar numa luz brusca, uma visão que aparece da fenda, primavera de Wordsworth ou maçã de Cézanne, silhueta de Macbeth ou Ahab. Então segue a massa dos imitadores, que remendam o guarda-sol, com uma peça que parece vagamente com a visão; e a massa dos glosadores que preenchem a fenda 
com opiniões: comunicação. Será preciso sempre outros artistas para fazer outras fendas, operar as necessárias destruições, talvez cada vez maiores, e restituir assim, a seus predecessores, a incomunicável novidade que não mais se podia ver. Significa dizer que o artista se debate menos contra o caos (que ele invoca em todos os seus votos, de uma certa maneira), que contra os "clichês" da opinião [DELEUZE e GUATTARI, 1992, p. 261].

A escola, por sua vez, por ser uma instituição basilar na organização do Estado contemporâneo e autorizada por este a educar as novas gerações, trabalha sobre o patrimônio cultural da humanidade, isto é, opera sobre conhecimentos estratificados. A escola faz parte desse guarda-sol que abriga e protege a humanidade da imensidão do caos, no qual se encontram "a massa de glosadores que preenchem a fenda com opiniões" e que tentam explicar e transmitir os conhecimentos adquiridos pelo Homem às novas gerações. A escola, nesta perspectiva apresentada por Deleuze e Guattari, não opera o conhecimento da mesma maneira que a ciência, a filosofia e a arte, pois se estas criam fissuras nos estratos ao operar no caos, aquela opera diretamente no conhecimento adquirido pela humanidade, escolarizando-o. O pensamento escolar, ao operar sobre os estratos, procura entender suas estruturas e as velocidades que Ihes deram origem para, por sua vez, criar os modos de transmissão para cada material. O pensamento escolar se revelaria, assim, nas maneiras de abrir e apresentar o mundo aos estudantes, pois, se para Deleuze e Guattari, "o professor não cessa de remeter a conceitos ensinados" (p. 83), essa abertura é que possibilitaria às novas gerações a criação de novas linhas de fuga e fissuras nos estratos através da arte, da filosofia e da ciência.

Nesta perspectiva, o saber da escola não se constitui como um saber científico ou filosófico, pois sua função é transmitir os conhecimentos consagrados por esses campos do conhecimento, instrumentalizando as novas gerações para que elas produzam ciência e filosofia. É o que se reconhece nos modos pedagógicos daquelas disciplinas que tradicionalmente integram os currículos da Educação Básica. Nelas, talvez se possam até mesmo realizar experimentos científicos, mas estes experimentos são aqueles consagrados pelas ciências, em que se sabe de antemão quais serão os resultados. Assim, o que se ensina na escola é a Biologia Escolar, não a Ciências Biológicas; a Química Escolar, não as 
Ciências Químicas. O mesmo ocorre com as ciências humanas, pois não se faz História ou Historiografia na escola, mas se transmite o que essas áreas do conhecimento já estabeleceram como verdades provisórias. Assim como a Geografia, a Sociologia e até mesmo a Literatura.

Porém, os professores de Arte e os arte educadores parecem querer criar, realizar processos pedagógicos que são também processos artísticos, mesmo que não resultem em uma obra acabada. Como afirmam Isabel Marques e Fábio Brazil, "ou o professor de Arte está interessado em construir conhecimento das/nas linguagens artísticas, ou não estará, necessariamente, ensinando arte" (MARQUES e BRAZIL, 2014, p. 31). Partindo-se desse pressuposto, para se "construir conhecimentos" no ensino da arte dentro da Educação Básica dever-se-ia, necessariamente, fazer, criar e produzir, operando sobre o caos, ao contrário das demais disciplinas escolarizadas, que estudam os pensamentos estratificados. Aqui há uma questão que precisa ser problematizada, pois esses princípios pedagógicos defendidos por esses e outros arte educadores talvez não sejam compatíveis às formas de operar o conhecimento da escola. $O$ ensino das linguagens artísticas no contexto escolar deve reproduzir as formas de pensar próprias da arte ou, pelo contrário, deve se debruçar sobre elas, transformando-as em objeto de estudo?

Por sua vez, os conhecimentos científicos e filosóficos, para se tornar objeto de estudo escolar, passam por um processo conhecido como transposição didática. Diversas passagens dos PCN remetem à necessidade de se realizar a transformação desses conhecimentos em conhecimentos escolares ao alertarem, por exemplo, que "na escola, a transposição didática desses estudos pode refletir o conservadorismo de determinados pontos de vista..." (BRASIL, 2000b, p. 8, grifo nosso). Os PCN-Arte também se referem a esta transformação ao afirmarem que os "os conteúdos da arte precisam ser transpostos didaticamente de maneira adequada" (BRASIL, 1998, p. 44, grifo nosso).

Documentos relativos à formação do Professor de Teatro, como as Diretrizes Curriculares para a Formação de Professores para a Educação Básica, em nível superior, nos cursos de licenciatura, apontam para a transposição didática como uma das capacitações necessárias que os professores de escolas formais devem possuir, segundo seu 
Art. 10. A seleção e o ordenamento dos conteúdos dos diferentes âmbitos do conhecimento que comporão a matriz curricular para a formação de professores, de que trata essa Resolução, serão de competência da instituição de ensino, sendo o seu planejamento o primeiro passo para a transposição didática, que visa a transformar os conteúdos selecionados em objeto de ensino dos futuros professores [BRASIL, Resolução CNE/CP 1, de 18 de fevereiro de 2002, grifos nossos].

Os Referenciais Curriculares dos Cursos de Licenciatura, do Ministério da Educação, referem-se à necessidade de domínio sobre este processo na definição do Perfil do Egresso de Cursos de Teatro - Licenciatura:

O Licenciado em Teatro é o professor que planeja, organiza e desenvolve atividades e materiais relativos ao Ensino da Arte Teatral. Sua atribuição central é a docência na Educação Básica, que requer sólidos conhecimentos sobre os fundamentos da Arte Teatral, sobre seu desenvolvimento histórico e suas relações com diversas áreas; assim como sobre estratégias para transposição do conhecimento artístico em saber escolar [BRASIL, 2010, p. 95, o segundo grifo é nosso].

Os educadores Lurdes de Fátima Polidoro e Robson Stigar (2010) veem a transposição didática ${ }^{16}$ como "um 'instrumento' pelo qual analisamos o movimento do saber sábio (aquele que os cientistas descobrem) para o saber a ensinar (aquele que está nos livros didáticos) e, por este, ao saber ensinado (aquele que realmente acontece em sala de aula)" (POLIDORO e STIGAR, 2010, p. 153). Neste sentido, há um trabalho de transformação dos conhecimentos estratificados em objeto de ensino, sem que se estabeleça uma hierarquia de saberes, pois o conhecimento escolar não é construído através de adaptações, nem de simplificações.

Esse processo de transformação do conhecimento se dá porque os funcionamentos
didático e científico do conhecimento não são os mesmos. Eles se inter-relacionam,
mas não se sobrepõem. Assim, para que um determinado conhecimento seja
ensinado, em situação acadêmico-científica ou escolar, necessita passar por
transformação, uma vez que não foi criado com o objetivo primeiro de ser ensinado. A
cada transformação sofrida pelo conhecimento corresponde, então, processo de
Transposição Didática [p. 155].

${ }^{16}$ O termo transposição didática foi introduzido, segundo Polidoro e Stigar, por Michel Verret, em 1975, e rediscutido por Yves Chevallard, em 1985, em seu livro La Transposition Didactique, no qual este educador "conceitua 'Transposição Didática' como o trabalho de fabricar um objeto de ensino, ou seja, fazer um objeto de saber produzido pelo 'sábio' (o cientista) ser objeto do saber escolar" (POLIDORO e STIGAR, 2010, p. 154). 
A partir desta perspectiva, o entendimento possível de uma das "tarefas" que caberia à escola seria a de transmitir e comunicar conhecimentos artísticos e não, necessariamente, criá-los, visto que, "para ocorrer 'transmissão' ou comunicação, é necessário que o conhecimento seja transformado" (p. 156).

Perspectiva semelhante a da transposição didática é apresentada por Jan Masschelein e Maarten Simons, em seu livro Em defesa da escola (2013), no qual a dupla de educadores belgas também discorre sobre a necessidade de se transformar o conhecimento e as habilidades produzidas no mundo em matéria escolar.

O conhecimento e as habilidades aprendidas na escola de fato têm uma clara ligação com o mundo - derivam dele, mas não coincidem com ele. Uma vez que o conhecimento e as habilidades são trazidos para dentro do currículo escolar, passam a ser matéria e, de certo modo, tornam-se separados da aplicação diária. É claro que as próprias aplicações de conhecimentos e de competências podem ser abordadas em um ambiente escolar, mas só depois de serem apresentadas como matérias. Esse conhecimento e essas habilidades são, assim, libertados, isto é, separados dos usos sociais convencionais, atribuídos na medida em que são apropriados para eles. Nesse sentido, a matéria sempre consiste em conhecimentos e competências autoindependentes [MASSCHELEIN e SIMONS, 2013, p. 32].

Aqui, o intuito é o de liberar uma coisa de seus usos para recriá-la como matéria de exploração, experimentação e descoberta. "É esse trazer para o jogo, esse transformar algo em matéria de estudo, que é necessário, a fim de se aprofundar em alguma coisa como um objeto de prática e de estudo" (p. 43, grifo dos autores). Masschelein e Simons não se utilizam do termo "transposição didática", mas do conceito de profanação:

Um tempo e um lugar profanos, mas também as coisas profanas, referem-se a algo que é desligado do uso habitual, não mais sagrado ou ocupado por um significado específico, e, portanto, algo no mundo que é, ao mesmo tempo, acessível a todos e sujeito à (re)apropriação de significado. [...] A matéria de estudo tem precisamente esse caráter profano [p. 39].

Profanar a matéria, na perspectiva de Masschelein e Simons, não é, estritamente, sinônimo de transposição didática, na perspectiva de Polidoro e Stigar, porém é uma maneira de fazê-la. Outros métodos e sistemas pedagógicos relativos ao ensino da linguagem teatral que se propõem a realizar essa transformação do 
conhecimento mundano em conhecimento escolar serão tratados ao longo deste trabalho. O que se quer, aqui, é problematizar as formas de operar dessas áreas do conhecimento humano: de um lado, a arte como criação, fissura nos estratos da cultura; de outro, a escola, que opera sobre conhecimentos estratificados, porém, colocando-os em suspensão, profanando-os, realizando uma transposição didática para que se possa estudá-los, experimentá-los.

A partir das diferentes formas de operar o conhecimento da arte e da escola, podem-se propor duas questões e seus possíveis desdobramentos. A primeira se refere à formação oferecida pelas diversas licenciaturas em Arte, no Brasil: nelas, os estudantes são capacitados para realizar a transposição didática como indicam os documentos oficiais, ou seja, serão capazes de profanar a matéria de estudo, retirando-Ihe seu caráter produtivo? Caso sejam, essas estratégias ao serem aplicadas no contexto da Educação Básica seriam as responsáveis por transformar em "cansativos" e "desgastantes" os "estudantes tradicionais", como se referiram Isabel Marques e Fábio Brazil (2014, p. 44)?

A segunda questão refere-se à possibilidade de que essas estratégias de transposição possam diminuir a perspectiva crítica do conhecimento artístico, "domesticando" seu potencial transgressor: seria desejável continuar lutando pela curricularização da arte mesmo se o conhecimento escolar e o saber da arte mostrarem-se excludentes e incompatíveis? Talvez esta segunda questão parta de um princípio questionável, no qual se desqualifica o conhecimento escolar imputando-lhe um caráter menor diante de outras áreas do conhecimento humano. Como se, ao se adjetivar como "escolar" o ensino da arte na Educação Básica, necessariamente se estaria subtraindo seu potencial crítico. Não se poderia pensar ao contrário, isto é, de que ao se chamar de "arte escolar" se estaria adicionando à arte o potencial de transformação que o ensino escolar tem em si? Masschelein e Simons referem-se a princípios como este, que desqualificam a escola e 0 conhecimento escolar, como uma das formas de se domar "seu caráter democrático, público e renovador" (MASSCHELEIN e SIMONS, 2013, p. 105), tema que será retomado mais a frente, quando se discorrer sobre os sentidos da escola.

No caso do Professor de Teatro, sua formação passa por processos pedagógicos que, mesmo voltados para o ensino formal, não deixam de dialogar 
com princípios sobre os quais os grandes criadores e pedagogos teatrais construíram suas obras e seus conhecimentos. A questão que se coloca é saber se estes princípios e conhecimentos podem ser transpostos para o conhecimento escolar e que atritos essas práticas provocariam no ambiente das escolas. A mentalidade e as formas de organização do sistema escolar suportariam tais ações pedagógicas? As pedagogias do teatro suportam ser transpostas em conhecimento escolar sem perda irremediável de seu sentido?

Talvez a transposição didática dos saberes da arte para os saberes escolares não seja possível ou desejável se concordarmos com o pensamento do professor e crítico de arte Jorge Coli. No livro O que é arte?, Coli afirma que a arte "nos ensina muito sobre nosso próprio universo, de um modo específico, que não passa pelo discurso pedagógico", construindo "um outro mundo, fecundo em ambiguidades" (COLI, 1995, p. 111). A especificidade da arte como forma de conhecimento se deve, sobretudo, por ela ser "portadora de sinais, de marcas deixadas pelo nãoracional coletivo, social, histórico", o que a faz "explodir toda intenção redutora, normalizadora ou explicativa", criando "conhecimentos bem diversos dos processos racionais" (p. 109). O que Coli parece defender é que toda arte carrega em si, intrinsecamente, seus próprios modos de ensino e aprendizagem, assim, qualquer tentativa de transformação desse conhecimento poderia caracterizar-se como uma forma de traição à própria arte.

Talvez o temor diante da escolarização da arte através de processos de transposição didática é que se repita o que aconteceu com o ensino da Literatura, no qual dificilmente se solicita aos alunos que realizem suas próprias leituras das obras estudadas ou que exercitem a criação de textos poéticos. As aulas de Literatura, em geral, procuram comunicar a explicação, remetendo a "conceitos ensinados" (DELEUZE e GUATTARI, 1992, p. 83), o que pode ser comprovado em livros e materiais didáticos voltados a esta disciplina, e mesmo em muitas questões presentes em exames vestibulares. O que suscita outro questionamento: seria a escola o lugar no qual o mundo é transformado em objeto de estudo, ou seria o local onde se transmitem as explicações e interpretações sobre ele? A se tomar a escola a partir da segunda perspectiva, talvez este não seja o ambiente mais apropriado para o ensino de arte, mas se pensarmos a escola como lugar de estudo, talvez a 
transposição didática e/ou a profanação da matéria possam ser instrumentos valiosos para a legitimação do conhecimento artístico. A questão, por ora, fica em suspenso, e voltaremos a ela mais a frente, quando serão problematizados os sentidos da escola.

\subsubsection{Arte educação e "Arte Escolar": fricções}

O temor diante das formas de curricularização e de transposição didática dos saberes da arte para o contexto escolar pode ser exemplificado no pensamento de Isabel Marques e Fábio Brazil. A dupla de arte educadores defende que a Arte como disciplina obrigatória na escola age no sentido de "dar acesso ao direito que todas as crianças, jovens e adultos têm a esse conhecimento universal" (MARQUES e BRAZIL, 2014, p. 29), porém, ao desconfiarem de sua escolarização (p. 44), propõem que se deva "repensar o papel da escola, no qual a arte tem uma grande contribuição. [...] A presença da arte na escola deve contribuir para uma visão mais aberta, mais flexível, menos arbitrária e menos compartimentalizada do ensino e de toda a gestão educacional" (p. 81). Os autores defendem que a escola, para abrigar a arte e suas modalidades de ensino, seja repensada e modificada, e para que isso aconteça sugerem que a própria forma de pensar das artes contribua para essa desejada transformação.

Os PCN-Arte, mesmo indicando a necessidade de transposição de conhecimentos, não são muito claros em relação a esse tema. Na apresentação da área afirma-se que a presença da Arte na Educação Básica objetiva o desenvolvimento do pensamento artístico e a percepção estética, "que caracterizam um modo próprio de ordenar e dar sentido à experiência humana" (BRASIL, 1998, p. 19), reconhecendo, assim, a arte como um "tipo particular de conhecimento" (p. 26). Dessa maneira, almeja que o aluno tenha uma "compreensão do mundo na qual a dimensão poética esteja presente" (p. 19), posicionando-se contrariamente a "visões pré-concebidas que reduzem a atividade artística na escola a um verniz de superfície" (p. 25). 
Esta maneira de apresentar a área pode nos remeter a outra forma de olhar para este tema, rapidamente abordada no primeiro capítulo deste trabalho: a dicotomia entre abordagens pedagógicas essencialistas, para as quais parecem apontar os PCN-Arte, e abordagens contextualistas, disseminadas nas escolas como se pôde constatar através dos relatórios de estágio dos estudantes de Teatro Licenciatura da UFAL ${ }^{17}$. Para Elliot Eisner, a abordagem contextualista "enfatiza as consequências instrumentais da arte na educação e utiliza as necessidades particulares dos estudantes ou da sociedade para formular seus objetivos" (EISNER apud KOUDELA, 1984, p. 18), enquanto a abordagem essencialista, nas palavras de Ingrid Koudela, considera que

a arte tem uma contribuição única a dar para a experiência e a cultura humanas, diferenciando-as de outros campos de estudo. Segundo os essencialistas, a arte não necessita de argumentos que justifiquem a sua presença no currículo escolar, nem de métodos de ensino estranhos à sua natureza [KOUDELA, 1984, p. 18].

Defende-se, assim, a inserção da arte no currículo escolar sem a necessidade de se recorrer a "métodos de ensino estranhos à sua natureza", o que pode significar a recorrência a métodos de ensino estranhos à própria educação escolar, conforme a hipótese levantada no início deste capítulo. As abordagens essencialistas pretendem evitar que o ensino da arte seja visto em função de outras áreas do conhecimento, como instrumento didático para o aprendizado de matérias relativas ao ensino de línguas, história, geografia etc., ou como articulador privilegiado de projetos interdisciplinares. Ou ainda, na perspectiva de Gilles Deleuze apresentada por Gualandi, pretendem libertar a "ideia de arte das interpretações que reduzem a autonomia da arte submetendo seu sentido aos discursos 'exteriores' da psicanálise, da sociologia ou da semiologia" (GUALANDI, 2003, p. 104). Quanto à recorrência a explicações psicológicas para a inserção da arte e do teatro no currículo escolar, Ingrid Koudela afirma que

a ênfase no desenvolvimento da personalidade resulta talvez de um preconceito que ainda hoje cerca o ensino do teatro. À ideia de que a educação dramática é um treinamento para o palco, professores opõem o argumento de que na aula de teatro a criança é levada a brincar dramaticamente, sendo que o teatro aparece por acidente e jamais como um valor. É a partir da justificativa de formação integral do educando que

\footnotetext{
${ }^{17}$ Ver página 44.
} 
o teatro passou a ser tolerado no currículo escolar, sem que o preconceito chegasse a ser questionado no seu fundamento (KOUDELA, 1984, p. 24).

Koudela refere-se a abordagens inspiradas nas propostas formuladas por Peter Slade, em seu livro O Jogo Dramático Infantil (SLADE, 1978), no qual uma "visão puramente espontaneísta" reduzia o ensino da arte e do teatro a "objetivos meramente psicológicos", o que afastava "a possibilidade de entender a arte como forma de conhecimento" (KOUDELA, 1984, p. 25). Para Masschelein e Simons, a psicologização da escola é outra das maneiras utilizadas para domar seu caráter democrático, tentando impedir que se disponibilize a todos 0 acesso aos conhecimentos produzidos pela humanidade:

O que ameaça o acontecimento escolar é a tendência a substituir o ensino por uma forma de orientação psicológica. [...] Uma expressão dessa tendência é a ênfase no bem-estar psicológico dos alunos e na "motivação para aprender". A psicologização acontece uma vez que 0 ato de levar em conta o mundo psicológico do aluno é tornado uma condição necessária para o ensino [MASSCHELEIN e SIMOS, 2013, p. 126].

Contrárias às abordagens contextualistas da arte, que recorrem a métodos de ensino que Ihe são estranhos e, muitas vezes, enfatizam o desenvolvimento emocional dos alunos, as abordagens essencialistas para o ensino do teatro ganharam espaço nos estudos da Pedagogia Teatral por meio de oficinas e cursos de iniciação artística em atividades de ação sociocultural com cunho educativo ou formativo. Porém parecem ainda enfrentar grandes barreiras dentro das escolas, mesmo diante da legitimação da Arte como área de conhecimento nos PCN-Arte. Estes, como dito acima, parecem pender para as abordagens essencialistas na Educação Básica ao reconhecerem na Arte um campo de conhecimento tão legítimo como os demais, e ao considerarem-na como Linguagem, no Ensino Médio, tão necessária para a formação do sujeito e do cidadão quanto Português, Educação Física e Língua Estrangeira Moderna.

A questão, porém, não se refere à legitimidade da arte como área de conhecimento, mas se as formas de criação artística devem ser transferidas para o ambiente escolar sem nenhuma ação de mediação ou de transposição didática, privilegiando somente o aprendizado através da criação e não do estudo e da 
experimentação dos objetos de arte. A visão dicotômica e excludente desses modos pedagógicos para a arte, essencialista e contextualista, talvez dificulte ainda mais a implementação dos PCN-Arte na Educação Básica brasileira. A educação formal trabalha sob a perspectiva de que os conhecimentos estratificados devem ser transpostos didaticamente para o ambiente escolar, o que os transformaria em saberes escolares. No caso do ensino do Teatro, no momento em que suas pedagogias privilegiam o aprendizado através do fazer e da instauração de processos de criação próprios à sua natureza, talvez se queira levar para o contexto escolar um modo de aprendizagem que não se coaduna com os modos da escola. Isto é, talvez a escola não seja o local de se fazer arte, bem como não o é de se fazer biologia ou história.

A defesa muitas vezes intransigente das abordagens essencialistas, justificada pela necessidade de legitimação da Arte como área de conhecimento, provocou, a nosso ver, a negação, também intransigente, de qualquer inferência exterior à área. A transposição didática e o estabelecimento de conteúdos conceituais serializados para todo o país parecem soar como uma espécie de ameaça às abordagens estritamente essencialistas, defendidas pelos arte educadores. Mas talvez seja o caso de se repensar o que poderia ser uma arte escolar e um teatro escolar levando-se em consideração as diferenças do contexto escolar e do contexto de ações socioculturais, no qual as abordagens essencialistas parecem se adequar melhor.

\subsubsection{Arte e cultura: fricções}

Este trabalho procura problematizar as relações entre a arte e seu ensino escolarizado, não sendo o conceito de cultura aqui priorizado. Porém, quando o senso comum vê arte e cultura quase como sinônimas, isto pode dificultar o entendimento da arte e de sua inserção, ou não, no contexto escolar. A abordagem deste tema, ainda que de forma sucinta, é necessária para elucidar a expressão "verniz de superfície", encontrada nos PCN-Arte (BRASIL, 1998, p. 25), na medida 
em que revela o sentido que o documento quer imprimir ao ensino da Arte e que não tem plena aceitação na comunidade escolar.

Contrariamente ao senso comum ao se abordar a maneira com que a arte opera para criar, segundo o pensamento de Deleuze e Guattari (1992), distinguimos arte de cultura. Afirmou-se que à arte caberia criar fissuras nos estratos culturais, nos conhecimentos já estabelecidos e referendados pela sociedade, colocando-a em um campo diferente da cultura. Visão semelhante é apresentada pelo cineasta JeanLuc Godard, em seu filme Je vous salue, Sarajevo (1993), ao dizer que "há uma regra e uma exceção: cultura é a regra e arte a exceção. [...] A regra quer a morte da exceção" (GODARD, 1993).

Nesta perspectiva, a compreensão de cultura e os objetivos da escola parecem se aproximar ao de um "bem comum", de um conhecimento que deva ser socializado e de um patrimônio que precisa ser conservado e compartilhado, enquanto a arte, por sua vez, subverteria esses campos do conhecimento. A partir dessa diferenciação entre arte e cultura, pode-se propor uma possível interpretação para a expressão "verniz de superfície" presente nos PCN-Arte como uma provocação, cujo objetivo é afastar o ensino da Arte de uma formação cultural vista somente como afirmação social. É o que Hannah Arendt chama de filisteísmo, ou seja, filisteu seria aquele sujeito que vê como finalidade da obra de arte a auto educação ou o auto aperfeiçoamento, isto é, o objeto artístico é empregado para finalidades dissimuladas.

O que irritava no filisteu educado não era que ele lesse os clássicos, mas que ele o fizesse movido pelo desejo dissimulado de auto-aprimoramento, continuando completamente alheio ao fato de que Shakespeare ou Platão pudessem ter a dizerIhes coisas mais importantes do que a maneira de se educar; o lamentável era que ele escapasse para uma região de "pura poesia" para manter a realidade fora de sua vida - coisas "prosaicas" como uma crise de batatas, por exemplo, - ou para contemplá-las através de um véu de "doçura e luz" [ARENDT, 2011, p. 255].

Arendt se refere ao uso que se faz da "ilustração cultural" como um bem de troca, como mercadoria, como se o refinamento cultural desse ao seu proprietário um status diferenciado diante dos demais; como se uma pessoa que soubesse quem era Bach pudesse receber um tratamento político e social diferenciado. Jorge Coli afirma que "tocar piano era, não faz muito tempo, parte integrante da educação das 
moças de 'boa família', como ainda hoje é enviá-las ao balé" (COLI, 1995, p. 103). Esse sentido restrito de cultura, que se baseia mais na informação do que na formação propriamente dita, está disseminado na comunidade escolar, sugerindo que exista uma espécie de superioridade intelectual e sensível de alguns, quando na verdade o aprimoramento artístico é um álibi que esconde a afirmação de classe.

Arendt parece apontar para uma espécie de "domesticação" da arte e da filosofia, de Shakespeare e Platão, através de um processo de fetichização cultural. Nesse processo, procura-se domar a potência crítica e desestabilizadora da arte, suas linhas de fuga e forças que provocam fissuras nos estratos, para transformá-la em objeto de, primeiro, status, e, depois, se possível, de troca. Mercadoria e consumo.

\section{Para Adorno e Horkheimer,}

A barbárie estética consuma hoje a ameaça que sempre pairou sobre as criações do espírito desde que foram reunidas e neutralizadas a título de cultura. Falar em cultura foi sempre contrário à cultura. O denominador comum "cultura" já contém virtualmente o levantamento estatístico, a catalogação, a classificação que introduz a cultura no domínio da administração [ADORNO e HORKHEIMER, 1985, p. 108].

Talvez seja necessário recordar Walter Benjamin ao dizer que "não há um único documento de cultura que não seja também um documento de barbárie. $E$ a mesma barbárie que o afeta, também afeta o processo de sua transmissão de mão em mão" (BENJAMIN apud CHAUÍ, 2000). Na visão de Adorno, segundo Wolfgang Maar, barbárie de uma sociedade que estrutura seu processo de desenvolvimento em bases materiais, identificando os bens culturais como mercadoria e transformando sua transmissão em capital, que teria no nazismo seu modelo exemplar. Barbárie de um processo educativo pautado na formação cultural através do esclarecimento da consciência, que deveria resultar em maior autonomia e emancipação intelectual, mas que se transforma em seu contrário por se render a uma racionalidade produtivista. Barbárie de um processo de criação de identidade nacional que transforma bens culturais em valores particulares de uma comunidade (de um povo, de uma nação), estabelecendo uma relação de superioridade moral (religiosa, de classe, racial) com o diferente, impossibilitando o contato com o outro e 
a abertura à história, e, por fim, inviabilizando qualquer desejo de autonomia (MAAR, 1995, p. 15-28).

A visão que associa a arte à cultura como conhecimento estratificado, inquestionável, canonizado e intocável pode concorrer para a afirmação de que algumas linguagens artísticas sejam expressão privilegiada de uma classe social, uma forma de distinção. Visão que também dissemina uma espécie de guetificação cultural, no sentido de criação de guetos socioeconômicos aos quais se associa uma determinada manifestação artística. São as famosas "ações sociais" voltadas para as camadas mais carentes da população e patrocinadas, ora por organizações nãogovernamentais, que oferecem cursos e oficinas de capoeira, hip hop, grafite e percussão, ora pelo poder público, através da organização do carnaval e de "eventos culturais" como grandes shows musicais. Aos mais abastados, por sua vez, as escolas particulares "vendem" cursos de balé, pintura e violino, e as políticas públicas de cultura investem em orquestras, salões de arte e mostras de dança. Nesta perspectiva de cultura, na qual as formas artísticas produzidas por uma elite intelectual e econômica são vistas como superiores, a arte na escola tanto pode se voltar à transmissão desse conhecimento de forma canônica, reproduzindo conceitos e juízos de valor já estabelecidos, sem possibilitar um real acesso a essa produção, como também pode se restringir, no caso das escolas públicas e de certas ações socioculturais, às manifestações artísticas que são produzidas pelas próprias comunidades, fazendo com que os indivíduos se tornem reféns dessas produções. Ou, pior, ao que a indústria do entretenimento chama de arte e cultura.

A distinção entre "cultura geral" de uma verdadeira formação cultural é abordada por Adorno, porém o autor alemão duvida da possibilidade de que esta possa ser conquistada através da educação escolar ou por meio de métodos de ensino. Ao falar sobre "ausência da formação cultural (Bildung) necessária a quem pretende ser um formador" (ADORNO, 1995, p. 63), ou seja, aos futuros professores, Adorno afirma que

a formação cultural é justamente aquilo para o que não existem à disposição hábitos adequados; ela só pode ser adquirida mediante esforço espontâneo e interesse, não pode ser garantida simplesmente por meio da frequência de cursos, e de qualquer modo estes seriam do tipo "cultura geral". Na verdade, ela nem ao menos corresponde ao esforço, mas sim à disposição aberta, à capacidade de se abrir a elementos do espírito, apropriando-os de modo produtivo na consciência, em vez de se ocupar com 
os mesmos unicamente para aprender, conforme prescreve um clichê insuportável [p. 64].

Diante de um processo de formação que é subjetivo, dependente do sujeito, caberia à escola, então, apresentar o mundo às novas gerações, criar interesse pelos bens culturais, possibilitar a abertura para o outro, tirar da circulação mercantilizada esses saberes produzidos pela humanidade e estudá-los como bens comuns, aos quais todos têm direito de acesso.

É preciso que a escola atue nos diversos âmbitos dessa questão, expropriando essa chamada "cultura de elite" das classes mais abastadas e transformando-a em bem comum e matéria de estudo, e, ao mesmo tempo, legitimando as manifestações artísticas vindas da tradição popular como arte, tornando ambas acessíveis a todos, igualitariamente, independente de origem social, antecedentes familiares ou talentos a serem desenvolvidos.

Neste sentido, Marques e Brazil afirmam que

conversar com a arte que os estudantes trazem é estabelecer diálogos entre o repertório do professor e o dos estudantes, o conhecimento universal e o conhecimento local. Estabelecem-se com isso redes de significações para que o próprio repertório dos estudantes possa ser relido (por eles mesmos) e para que também se apropriem significativamente de outros repertórios e possibilidades de arte [MARQUES e BRAZIL, 2014, p. 124].

Dessa maneira, para estes autores, "reproduzir ingenuamente a suposta arte dos estudantes não permite recriar, articular, ampliar possibilidades e conhecimentos" (p. 124), sendo que, por detrás desse discurso de "valorização dos estudantes", muitas vezes se esconde a ideia "da inutilidade de alguns conhecimentos 'superiores' para certas camadas da população" (p. 125).

\subsection{Os sentidos da arte}

A forma de pensar própria da arte e que a diferencia das formas de pensar da escola, a utilização ou a rejeição de um "instrumento" chamado transposição 
didática, as diferenças entre a educação escolar e a ação sociocultural no ensino da arte e o entendimento de cultura como conhecimento estratificado e forma de distinção social são, para nós, elementos que colocam em questão uma possível "incompatibilidade de gênios" entre a escola e a arte, entre os saberes escolares e os saberes próprios da arte. Mas dentro de cada um desses campos do conhecimento existe ainda uma multiplicidade de sentidos que, ao serem problematizados, podem ajudar a entender a complexidade do tema tratado.

A palavra arte, por exemplo, vem sendo empregada neste trabalho desde a apresentação, mas será que seu significado é entendido de uma maneira única por todos? Quando os arte educadores, os professores de Arte, os formadores desses professores, os pesquisadores de pedagogias das artes falam sobre arte talvez imaginem que estejam sendo entendidos plenamente por todos. Porém, parece que esta não é uma verdade verificável. O que é arte, qual seu sentido, sua tarefa, suas funções no mundo não possuem o mesmo entendimento pela comunidade escolar e, ouso dizer, nem mesmo entre os artistas e os arte educadores. Se, acima, foram mencionadas algumas perspectivas discordantes quanto ao conceito de cultura, o mesmo pode ser dito sobre a arte.

No início deste trabalho foram expostas algumas consequências da dificuldade de entendimento da arte no ensino escolar, tais como: a utilização do mesmo espaço de aula das demais disciplinas para Arte (o que não se observa, por exemplo, no caso da Educação Física); a obrigatoriedade que algumas escolas impõem à Arte para que se produza uma espécie de conhecimento que possa ser avaliado por meio de provas escritas; o curto tempo de aula para que um processo artístico-pedagógico possa ser desenvolvido; as solicitações para que o professor de Arte se responsabilize, durante suas aulas, pelas atividades espetaculares e de decoração de ambiente para os eventos e festas escolares, mesmo que estes não façam parte dos conteúdos da disciplina; o entendimento de arte restrito ao seu produto final ou espetacular, deslegitimando os processos pedagógicos e de criação; a indistinção entre poética, estética e técnica; entre outros.

E se arte não possui um entendimento comum entre a comunidade escolar e os arte educadores, os modos pedagógicos e as necessidades inerentes ao seu ensino também irão padecer por esta falta de clareza. A problematização das 
diferentes perspectivas existentes sobre a arte talvez possa trazer à tona algumas discordâncias encobertas, muitas vezes ignoradas, em nossas práticas e discursos, até mesmo de forma inconsciente.

\subsubsection{Quando se fala de arte, do que se está falando?}

Primeiramente, é importante ressaltar que "a ideia de arte não é própria a todas as culturas" (COLI, 1995, p. 64), ou seja, não é possível estabelecer critérios internos à noção de obra de arte, mas somente fora dela, o que nos coloca no território contraditório, inconsistente e movediço do discurso. Para Coli, "estamos diante de produtos que nos escapam, que se desenvolvem de modo tão inesperado, tão pouco previsível" (p. 35), que fogem à possibilidade de dominá-los, pois "a riqueza do objeto artístico escapa sempre aos moldes que se querem lógicos" ( $p$. 61), presentes nos discursos, nas classificações e nos sistemas de organização. Dessa maneira, o "em si" da obra de arte é uma projeção, "somos nós que enunciamos o 'em si' da arte, aquilo que nos objetos é, para nós, arte” (p. 64). O que fez Marcel Duchamp dizer que "são os 'olhadores' que fazem um quadro" (apud COLI, 1995, p. 68).

Sendo a arte uma criação cultural, o filósofo francês Jacques Rancière, em seu livro A partilha do sensível (2009), detecta, na tradição ocidental, três grandes regimes de identificação para o que é chamado de arte. O primeiro ele denomina regime ético das imagens, pois deriva de uma visão de arte que se submete à imagem quanto à sua origem, isto é, seu teor de verdade, e à sua finalidade, ou seja, seus usos e efeitos na educação das crianças e dos espectadores cidadãos. Quanto à sua origem, as imagens podem ser "verdadeiras, isto é, saberes fundados na imitação de um modelo com fins definidos, [ou] simulacros de arte que imitam simples aparências" (RANCIĖRE, 2009, p. 28). Estruturado a partir do pensamento platônico, esse regime trata "de saber no que o modo de ser das imagens concerne ao ethos, à maneira de ser dos indivíduos e das coletividades. E essa questão impede a 'arte' de se individualizar enquanto tal” (p. 29). 
A perspectiva ética da arte dentro do contexto escolar revela-se quando os processos de produção e criação são secundarizados em relação aos produtos finalizados, e se associam essas produções somente à sua utilidade na educação dos alunos. Trata-se de abordagens contextualistas nas quais as linguagens artísticas não se legitimam por si, mas estão a serviço de outros conhecimentos e disciplinas. $O$ valor da arte é reduzido a sua aplicabilidade à realidade.

O segundo regime de arte é denominado por Rancière de poético ou representativo, pois estruturado no par poiesis/mímesis, que tem sua origem no pensamento aristotélico. Ao contrário de Platão, que propunha uma divisão das artes em verdadeiras e em simulacros, Aristóteles divide-as a partir de suas maneiras de fazer, suas poéticas, mais precisamente nas suas maneiras de imitar. O que importa é o feito, a imitação, a obra, não o ser imitado. A denominação desse regime como representativo se refere à noção de representação que organiza as maneiras de fazer, ver e julgar (p. 31), ou seja, de se apreciar a imitação. Trata-se de um regime de visibilidade das artes no qual, ao mesmo tempo, se "autonomiza as artes, mas também [...] articula essa autonomia a uma ordem geral das maneiras de fazer e das ocupações" (p. 31).

Quando se trata do regime poético ou representativo como forma de identificação da arte, exemplos são facilmente encontrados no contexto escolar e na sociedade. Em geral, referem-se à necessidade da representação artística imitar a realidade, como na expressão "a arte imita a vida", ou no seu oposto, "a vida imita a arte", que participa do mesmo pressuposto de representação e mímesis. Nesta perspectiva, quanto mais próxima do real, maior valor terá a representação artística. Ainda que neste regime se reconheça a autonomia da arte, sua valoração está ligada à sua capacidade de reprodução do real, ou seja, benfeita e malfeita. Pode-se detectar ecos desta identificação poética nos próprios PCN-Arte, que propõem que o ensino da Arte seja realizado por meio do aprendizado de linguagens artísticas, que, por sua vez, são caracterizadas por suas formas de produção. Trata-se de uma perspectiva de arte que privilegia, portanto, as maneiras de fazer, as poéticas, em relação aos sentidos, a estética.

Por fim, o terceiro regime das artes seria o estético, para o qual Rancière "toma emprestado" o estado estético schilleriano para marcar sua identidade: "O 
estado estético é pura suspensão, momento em que a forma é experimentada por si mesma. O momento de formação de uma humanidade específica" (p. 34). A identificação da arte se faz pela distinção de um modo de ser sensível próprio aos produtos da arte, ou seja, remete "ao modo de ser específico daquilo que pertence à arte, ao modo de ser de seus objetos" (p. 32).

No contexto escolar, pode-se associar o regime estético às abordagens essencialistas, nas quais se privilegia o aprendizado da arte como linguagem, isto é, a articulação de signos e significantes próprios que produzem sentidos, tanto em seus aspectos de produção como de recepção e leitura.

A legitimidade desses três regimes das artes não deve ser reduzida a uma ordem cronológica, que teria seu início em Platão, passaria por Aristóteles e chegaria a Schiller. Não se trata de um processo evolutivo, de transformação ao longo do tempo, no qual cada regime pode ser explicado a partir do precedente e/ou de acordo com o contexto no qual se formou. O que se percebe é que a existência dos três regimes se superpõe, numa convivência temporal, dentro do contexto escolar e também no próprio pensamento ocidental.

Por vezes, percebe-se até mesmo a tentativa de coexistência de dois desses regimes sob uma única identidade, como na afirmação de que "a ética e a estética são uma coisa só", na qual se procura aliar a percepção da forma à perspectiva platônica, vinculando a arte à educação do sujeito. Criado pelo austríaco Wittgenstein, trata-se de um aforismo herdeiro de uma tradição filosófica que associa o bem à beleza, mas que na obra de Hegel e Schelling significará a supremacia do logos sobre a sensibilidade. No ensaio Ética contra estética, a filósofa espanhola Amelia Valcárcel problematiza o aforismo ao propor que "a única forma de dar-lhe um sentido é afirmar que no pensamento de Wittgenstein a arte supõe uma ética, quer dizer, que toda estética leva consigo uma ética sobreposta. A arte é então simulacro e a ética continua sendo inefável. A arte mostra justamente esse inefável" (VARCÁRCEL, 2005, p. 6). Ainda que se reconheça que Wittgenstein rejeite qualquer finalidade pedagógica para a arte, ao contrário do pensamento platônico, a arte seria pedagógica justamente por não pretender sê-lo. 
A justaposição dos regimes ético e estético justifica, por exemplo, uma perspectiva política para o ensino da Arte, defendida por arte educadores que trabalham com o chamado teatro político. Baseado em poéticas teatrais que privilegiam a seleção de recortes da realidade e os efeitos de sua representação sobre a mesma, essa perspectiva político-pedagógica do teatro tende a colocar o objeto artístico em segundo plano. Ao transferir o foco do pensamento artístico para a sociedade, isto é, para fora da obra, acaba-se por retirar da arte sua autonomia.

Retoma-se a questão colocada anteriormente de que a dicotomia entre abordagens contextualistas e essencialistas para o ensino da arte no ambiente escolar poderia estar dificultando ainda mais a inserção das linguagens artísticas nesse contexto. Se o objetivo da escola é formar o sujeito através de um processo dialético que confronta sua subjetividade com a objetividade do mundo, o que inclui os paradigmas da sociedade na qual ele está inserido, talvez a arte como disciplina escolar e componente curricular tivesse que se submeter aos modos pedagógicos escolares e não o contrário, como defendem Isabel Marques e Fábio Brazil (2014, p. 81). A distinção dessas abordagens carece de uma "transposição didática" para o ambiente escolar, pois talvez não seja viável o ensino da arte nesse contexto através de uma abordagem puramente essencialista, visto que o "material" a ser trabalhado na escola não é somente a arte, mas o próprio homem.

Diante da coexistência entre os regimes da arte, tal como foram definidos por Rancière, a identificação com um pode significar a rejeição aos demais, o que é explicitado por meio de discursos de desqualificação, transformando as tentativas de inserção da arte no currículo escolar, mais uma vez, em diálogo de surdos. Os exemplos dessa coexistência temporal dentro da escola podem servir para mostrar quão complexo e contraditório é estabelecer um sentido único e totalizante para a arte neste contexto.

\subsubsection{A estética e a poética no contexto escolar}


A identidade que a arte assume tanto no regime representativo ou poético quanto no regime estético coloca-a em uma posição de autonomia diante de outras áreas do conhecimento, assim como defendem as abordagens pedagógicas essencialistas e se configura como a perspectiva predominante nos PCN-Arte. Porém, percebemos que muitas vezes estética e poética são tratadas como sinônimas nas práticas pedagógicas no contexto escolar, como se 0 ato de apreensão e percepção da obra de arte e o ato do fazer fosse da mesma natureza, provocando, a nosso ver, uma série de confusões quanto aos objetivos e modos de ensino da arte na escola.

O termo estética (do grego, aisthetikos, "que pode ser percebido pelos sentidos") se insere no campo da filosofia como "ciência do conhecimento sensível" (RUSS, 1994, p. 94). Por sua vez, a poética busca dar a ver através de uma ação no mundo, um fazer. "Algo de trabalho subjetivo, de pensamento ou de sensibilidade, está implicado na poiesis” (MATTOS, 2014, p. 2). A poética trata, assim, das práticas artísticas, das maneiras de fazer, enquanto a estética trata das "formas de visibilidade das práticas da arte, do lugar que ocupam, do que 'fazem' no que diz respeito ao comum" (RANCIĖRE, 2009, p. 17).

O ensino de Arte na escola padece com essa falta de distinção dos dois campos, pois, por vezes, as aulas se transformam em aulas de poéticas, de maneiras de fazer, de suas técnicas e práticas de como lidar com a matéria, ignorando a apreensão de objetos artísticos vindos de fora da sala de aula. A arte torna-se um exercício de autoexpressão, no qual as referências externas, quando existem, estão a serviço do fazer e são vistas como materiais poéticos. A reflexão e a contextualização se restringem ao que "se deu a ver" naquela aula, isto é, ao que foi criado pelos alunos, ignorando-se as aproximações ao patrimônio cultural da humanidade.

Outras vezes, as aulas de Arte se transformam em uma ação de educação estética, que se restringe a dar instrumentos de contextualização e reflexão oriundos da história da arte, nos quais a apreensão sensível do objeto se faz através de uma análise intelectual. Tal análise ora pende para uma interpretação sociológica, em que a obra de arte é vista como puro reflexo do contexto social no qual ela foi criada, ora para uma interpretação "estética", dir-se-ia melhor, estilística, pois a leitura se 
restringe aos estilos e às técnicas, localizados historicamente ou na obra de determinados artistas referenciais. A ausência de leitura, fruição e percepção do objeto artístico em si enquanto "composição do caos", para usar os termos de Deleuze e Guattari (1992, p. 263), demonstra a limitação dessa educação estética. A transposição didática parece esquecer-se de seu material de estudo, a arte em si, e se volta somente à comunicação das interpretações exteriores sobre a obra.

Para nós, uma perspectiva possível para o ensino de Arte na escola pode ser encontrado no pensamento de Jacques Rancière que, com o objetivo de definir as articulações do regime estético das artes, suas possibilidades e seus modos de transformação, propõe um sentido para o termo estética: "um modo de articulação entre maneiras de fazer, formas de visibilidade dessas maneiras de fazer e modos de pensabilidade de suas relações, implicando uma determinada ideia da efetividade do pensamento" (RANCIÈRE, 2009, p. 13). Este sentido se aproxima da proposta de abordagem triangular para o ensino da Arte, formulada por Ana Mae Barbosa, ou seja, as articulações pedagógicas entre o fazer ("maneiras de fazer"), o fruir ("formas de visibilidade") e o contextualizar ("modos de pensabilidade"). Observe-se, porém, que o sentido proposto por Rancière refere-se ao termo estética e não à poética, o que se configura como uma perspectiva sobre a arte, um ponto de vista de onde se olha para essa área do conhecimento. O que sugere uma questão sobre a indicação da abordagem triangular pelos PCN-Arte: qual a perspectiva que se quer para 0 ensino da arte dentro da escola? Deseja-se uma perspectiva poética, mais afeita ao fazer, ou uma perspectiva estética, cujo foco é dado pela recepção e apreensão do objeto e do processo artísticos, ou ainda uma perspectiva ética, que contextualize os conhecimentos já estratificados da arte com a finalidade de formação do sujeito? Em nosso diálogo de surdos, diferentes perspectivas são tomadas como únicas, conversas mal conversadas encerram questões não resolvidas. Deve-se colocar um acento para a realização da abordagem triangular dentro da escola, e, se sim, onde colocá-lo: no fazer, no fruir ou no contextualizar?

Talvez a resposta para esta questão não esteja na arte e em suas pedagogias, mas no entendimento de qual seria o sentido da escola para a sociedade brasileira e, por conseguinte, da arte escolarizada. Talvez a determinação 
de uma perspectiva que possa indicar mais claramente o tipo de formação artística que se quer na Educação Básica do país emerja da/na escola.

\subsection{Os sentidos da escola}

A palavra escola, assim como a palavra arte, também vem sendo empregada indiscriminadamente desde o início deste trabalho. Mas, quando se fala escola, o que se está querendo dizer? O que se entende por escola e qual seria seu sentido em nossa sociedade? O que se percebe é que quando os arte educadores, os professores de arte, os formadores desses professores, os artistas e os pesquisadores de pedagogias da arte falam em escola parece que possuem uma compreensão diferente daquela vinda da comunidade escolar. O entendimento do sentido da escola possui muitas perspectivas e desencontros, inclusive internos a esses dois grupos, o que dificulta ainda mais a inserção da arte no contexto escolar.

Os discursos dos arte educadores, em geral, revelam uma incompreensão da escola, o que talvez se deva à rejeição que os modos pedagógicos e as formas de abordagem vindas da arte muitas vezes recebem no contexto escolar. Talvez esse desconhecimento ou mesmo a discordância em relação aos modos pedagógicos próprios da escola faça com que nós, arte educadores, tenhamos dificuldade para traçar os objetivos da arte dentro da estrutura curricular e até mesmo diferenciar o que seria o ensino da arte do ensino das linguagens artísticas, como propõem os PCN-Arte.

As diversas perspectivas sobre o sentido da escola faz com que esse ambiente de educação possa se prestar a uma pluralidade de proposições pedagógicas, a objetivos sociais conflitantes e a projetos políticos de poder. Esperase da escola que ela corrija a sociedade e que forme uma nova geração de acordo com princípios estabelecidos a priori, muitas vezes conflitantes entre si. Diversos grupos se debatem para implementar as melhores e mais eficientes formas de aprendizagem escolar visando sempre uma melhoria do mundo, porém sempre sob uma visão parcial e particularizada do que seria melhor para o mundo. A escola vira, 
assim, um campo de batalhas ideológicas, políticas, sociais e econômicas. A possível ausência de denominadores comuns sobre o sentido da escola faz com que todas as possibilidades em se dar um sentido a ela se apresentem como plausíveis. Talvez seja, portanto, necessário estabelecer alguns sentidos comuns para a escola, a partir dos quais se possa pensar sua existência e sua singularidade e, por conseguinte, o papel da arte neste contexto.

\subsubsection{Sobre a crítica às "pedagogias do aprender a aprender"}

A escola como parte indissociável do corpo social e instituição essencial para o funcionamento do Estado moderno tende a refletir aspectos, valores e ideologias da sociedade na qual está inserida, em geral, reproduzindo-os e realimentando-os. Neste sentido, pode-se sugerir que, da perspectiva das classes dominantes, a escola serve para formar os homens e as mulheres que, no futuro, farão parte da sociedade tal como ela se apresenta hoje, na tentativa de perpetuar a ideologia e o poder dessas classes. Por um lado, trata-se de processos educativos necessários, que visam a adaptação do sujeito ao seu meio, segundo o filósofo Theodor W. Adorno, pois "a educação seria impotente e ideológica se ignorasse o objetivo de adaptação e não preparasse os homens para se orientarem no mundo" (ADORNO, 1995, p. 145). Por outro lado, como adverte Adorno, a educação "seria igualmente questionável se ficasse nisso, produzindo nada além de well adjusted people, pessoas bem ajustadas, em consequência do que a situação existente se impõe precisamente no que tem de pior" (p. 145). Para Masschelein e Simons,

não há nada de errado com as competências (profissionais) em si mesmas. O problema surge quando as transformamos no objetivo fundamental da escola - como muitas vezes acontece - e quando começam a funcionar como resultados de aprendizagem que devem ser produzidos como produtos; em resumo, quando a aprendizagem (competências) toma o lugar do estudo e da prática [MASSCHELEIN e SIMONS, 2013, p. 90].

As modernas teorias pedagógicas surgidas ao longo do século $X X$, que "consistem de uma impressionante miscelânea de bom senso e absurdo [...], sob a 
divisa de educação progressista", segundo Hannah Arendt (2011, p. 226), parecem incorrer no erro apontado por Adorno. Ao negarem os modos pedagógicos da escola tradicional, essas teorias acabaram por estruturar seus modos de operar sobre 0 conhecimento escolar de forma semelhante ao funcionamento da sociedade que dizem criticar, sem perceberem que "a organização do mundo converteu-se a si mesma imediatamente em sua própria ideologia. Ela [a organização do mundo] exerce uma pressão tão intensa sobre as pessoas, que supera toda a educação" (ADORNO, 1995, p. 143). Assim, ao contrário da transformação da sociedade, presente nos objetivos formulados por esses movimentos de renovação da educação, suas ações fizeram com que a escola se voltasse cada vez mais à adaptação do homem ao seu meio, como sugere José Carlos Libâneo:

A transformação geral da sociedade repercute, sim, na educação, nas escolas, no trabalho dos professores. Embora seja verdade que tal repercussão tem se caracterizado pela subordinação da educação à economia e ao mercado com pouca ou nenhuma preocupação com a desigualdade e o destino social das pessoas, não se pode deixar de investir numa proposta de escola democrática que contemple conhecimentos, habilidades e valores necessários para a sobrevivência no mundo complexo de hoje [LIBÂNEO, 1998, p. 9].

Libâneo, mesmo reconhecendo as influências políticas sobre a educação escolar, parece aceitá-las e propõe que a escola prepare o sujeito para "sobreviver no mundo complexo de hoje", ou seja, se volte para a preparação e a formação do futuro cidadão para que este possa concorrer e sobreviver no mercado de trabalho. Masschelein e Simons analisam algumas consequências práticas dessas teorias:

Atualmente, as instituições e os ideais, obviamente, perderam muito de seu significado, e a transferência de conhecimento e a educação centrada no professor estão fora de moda. Exatamente por causa disso, as escolas modernas estão sendo convertidas em ambientes de aprendizagem centrada no aluno. A crença na tradição e na transferência tem sido substituída por uma crença no poder criativo do indivíduo e na singularidade do aprendiz. [...] O resultado é que os alunos são domados: eles se tornam escravos de suas próprias necessidades, um turista no seu próprio mundo da vida. A importância colocada sobre aprender a aprender é, talvez, a mais reveladora expressão dessa tentativa de domar. O aluno é atirado de volta ao seu próprio aprendizado e a ligação com "alguma coisa" - com o mundo - é rompida [MASSCHELEIN e SIMONS, 2013, p. 107].

A organização ideologizante do mundo no século $X X$ produziu, segundo Arendt, "a ilusão emergente do pathos do novo" (ARENDT, 2011, p. 226). A 
apropriação da ideia do novo pelo sistema capitalista está disseminada em toda sua estrutura e pode ser detectada nas falas dos pedagogos progressistas, nos discursos político-partidários e na utilização que a propaganda faz de palavras como mudança, novidade e inovação, nas quais se baseia a sociedade de consumo vigente. As inovações tecnológicas, em lugar de aproximar economicamente as pessoas, são usadas para acirrar ainda mais as diferenças sociais, através da manutenção do status quo. Para Adorno e Horkheimer,

O que é novo na fase da cultura de massas em comparação com a fase do liberalismo avançado é a exclusão do novo. A máquina gira sem sair do lugar. Ao mesmo tempo que já determina o consumo, ela descarta o que ainda não foi experimentado porque é um risco. [...] Nada deve ficar como era, tudo deve estar em constante movimento. Pois só a vitória universal do ritmo da produção e reprodução mecânica é a garantia de que nada mudará, de que nada surgirá que não se adapte [ADORNO e HORKHEIMER, 1985, p. 111].

"Mudar para não mudar" parece ser o mantra dos defensores da globalização do capital e que se reflete nas diversas propostas de mudança para a educação escolar. 'A 'inovação' torna-se o sintoma de uma escola 'excelente'. Para tal escola, a inovação competitiva é um objetivo em si, sem necessidade de maiores explicações" (MASSCHELEIN e SIMONS, 2013, p. 125).

Nova foi o adjetivo utilizado para a escola defendida pelo movimento de renovação do ensino, surgido em fins do século XIX e com grande recepção e aceitação na primeira metade do século XX. A Escola Nova defendia modos pedagógicos que se opunham aqueles da educação tradicional, vistos politicamente como conservadores. Diversas propostas pedagógicas surgidas na segunda metade do século XX foram influenciadas pela Escola Nova, cujas mudanças são caracterizadas da seguinte maneira, por Demerval Saviani:

Compreende-se, então, que essa maneira [da Escola Nova] de entender a educação, por referência à pedagogia tradicional, tenha deslocado o eixo da questão pedagógica do intelecto para o sentimento; do aspecto lógico para o psicológico; dos conteúdos cognitivos para os métodos e processos pedagógicos; do professor para o aluno; do esforço para o interesse; da disciplina para a espontaneidade; do diretivismo para o não-diretivismo; da quantidade para a qualidade; de uma pedagogia de inspiração filosófica centrada na ciência e na lógica para uma pedagogia de inspiração experimental baseada principalmente nas contribuições da biologia e da psicologia. Em suma trata-se de uma vertente pedagógica que considera que o importante não é aprender, mas aprender a aprender [SAVIANI apud MESQUITA, 2010, p. 66]. 
$\mathrm{Na}$ "nova ordem mundial", que se impôs como ideologia única com o fim da União Soviética, em 1992, qualquer proposta educacional para a educação pública que vise retomar alguns aspectos dos modos pedagógicos tradicionais é rechaçada em nome da necessidade de adequação da escola aos novos tempos, sempre rápidos, nos quais todos devem estar prontos para tudo, sendo a flexibilidade e a adaptação às mudanças as palavras de ordem vindas do mundo corporativo. O capital, temeroso diante de mudanças estruturais do sistema econômico mundial, apropriou-se dos discursos de renovação e os transformou em fetiche, num movimento a favor do próprio capital. Tudo o que é novo vira mercadoria para ser, rapidamente, consumido, dando lugar a novas mercadorias e fazendo girar a roda da economia e da sociedade de massas. "Em uma época de inovação, aquilo que existe atualmente é, por definição, obsoleto no momento em que é criado" (MASSCHELEIN e SIMONS, 2013, p. 125).

Com o objetivo de contribuir para a construção de uma pedagogia históricocrítica, o Grupo de Pesquisa "Estudos Marxistas em Educação"18 tem se voltado à crítica ao pragmatismo neoliberal presente no pensamento educacional brasileiro, desde o final do século XX, e ao que denominam, inspirados em Demerval Saviani, como "pedagogias do aprender a aprender". A Professora Doutora Lígia Martins, líder do grupo ao lado do Professor Doutor Newton Duarte, descreve, ironicamente, essas novas formas educativas:

Diante de um mundo em "constantes transformações", mais importante que adquirir conhecimentos, posto sua "transitoriedade", será o desenvolvimento de competências para o enfrentamento dessas. Apela-se, pois, à formação de personalidades flexíveis, criativas, autônomas, que saibam trabalhar em grupos e comunicar-se habilmente e, sobretudo, estejam aptas para os domínios da "complexidade do mundo real".

Tendo em vista essa "preparação", a resolução de problemas erige-se como exigência básica da educação escolar, de tal forma que a aprendizagem baseada em problemas se converte na estratégia azada para a formação de indivíduos "participativos". Caberá à escolarização oportunizar os meios pelos quais o aluno se coloque como sujeito de sua aprendizagem, entendendo-se que, assim, consequentemente, ocupará seu lugar na sociedade de modo "crítico" e "cidadão" [MARTINS, 2010, p. 22].

\footnotetext{
${ }^{18}$ Grupo ligado à Faculdade de Ciências e Letras, da Universidade Estadual Paulista "Júlio de Mesquita Filho" (UNESP), do Câmpus de Araraquara.
} 
As "pedagogias do aprender a aprender", que sustentam os quatro pilares da

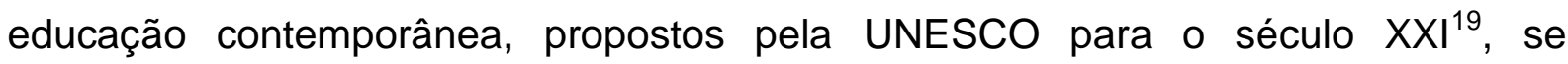
tornaram um pensamento quase hegemônico nas secretarias de educação municipais e estaduais espalhadas pelo Brasil, com ampla repercussão nos currículos dos cursos de pedagogia e licenciatura. Aprender a conhecer, aprender a fazer, aprender a viver com os outros e aprender a ser são os quatro fundamentos presentes nos documentos oficiais e nos discursos e práticas de formação dos professores brasileiros. Se antes a escola era vista como o lugar da transmissão de conhecimentos estratificados, agora a educação escolar deve privilegiar o aprendizado a partir da construção do conhecimento e do protagonismo dos alunos. O construtivismo, a pedagogia do professor reflexivo, a pedagogia das competências, a pedagogia dos projetos e a pedagogia multiculturalista, que se alinham às propostas de educação da UNESCO, são as chamadas "pedagogias do aprender a aprender". Para o educador Newton Duarte,

a despeito das especificidades de cada uma, elas apresentam uma mesma tônica: a negação daquilo que chamam "educação tradicional". Elas podem ser consideradas pedagogias negativas, na medida em que aquilo que melhor as define é sua negação das formas clássicas de educação escolar [DUARTE, 2010, p. 34].

Nessas pedagogias, "o professor deixa de ser um mediador entre o aluno e o patrimônio intelectual mais elevado da humanidade, para ser um organizador de atividades" (p. 38). Quanto aos conteúdos conceituais, a aprendizagem significativa ou do conteúdo contextualizado considera "conteúdos significativos e relevantes para o aluno aqueles que tenham alguma utilidade prática em seu cotidiano" (p. 38), fazendo com que se torne uma atitude antipedagógica ensinar conteúdos sem esse caráter utilitário. A mesma crítica valeria para o construtivismo, referenciado pela epistemologia genética de Jean Piaget, no qual as atividades de maior valor educativo seriam aquelas que atuassem no processo espontâneo de desenvolvimento do pensamento. Duarte afirma que

\footnotetext{
${ }^{19}$ Os quatro pilares para a educação foram definidos na Conferência Mundial de Educação para Todos, realizada em Jomtien, na Tailândia, em 1990, e definidos como metas para o desenvolvimento educacional em todos os países signatários de seus documentos, dentre eles, o Brasil.
} 
nessa perspectiva não importa o que o aluno venha a saber por meio da educação escolar, mas sim o processo ativo de reinvenção do conhecimento. Aprender o conteúdo não é um fim, mas apenas um meio para a aquisição ativa e espontânea de um método de construção de conhecimentos [p. 41].

Segundo José Luis Derisso, as "pedagogias do aprender a aprender" carregam "a ilusão de que por meio da educação se corrigiriam os males da sociedade" (DERISSO, 2010, p. 57), mas suas ações acabam por reproduzir as formas de operar próprias dessa sociedade que se quer corrigir, pois são baseadas na aquisição de competências para a solução de problemas. Para Lígia Martins, quando "as dimensões técnicas da prática de ensino passam a ocupar um lugar central, em detrimento de seus próprios fundamentos [teóricos], privilegia-se a forma mutilada de conteúdo!" (MARTINS, 2010, p. 23).

Concebendo a formação como um processo que a pessoa, em formação, realiza sobre si mesma e o conhecimento, como instrumento para a resolução de problemas práticos imediatos, esse modelo visa à elaboração de ações adequadas aos contextos e às próprias possibilidades nele existentes, o que, em última instância, significa preparar os indivíduos para a plena adaptação às circunstâncias sem debruçar-se sobre a real compreensão de seus determinantes. Por essa via, ratifica-se a cotidianidade, o "recuo de teoria" e a empiria no âmbito da educação escolar, dados que ampliam sobremaneira os limites a uma formação escolar verdadeiramente emancipatória [p. 28].

A "plena adaptação às circunstâncias", a "cotidianidade" e a "empiria" na educação escolar, apontadas por Martins, fazem parte da organização ideologizante da sociedade, denunciada por Adorno, que produziria somente aquelas pessoas bem ajustadas (well adjusted people), impedindo a renovação do mundo pelas novas gerações.

A educação escolar que visa à construção do conhecimento em detrimento à transmissão dos conhecimentos já formulados pela humanidade também é defendida pela pedagogia dos projetos, pela pedagogia do professor reflexivo e pela pedagogia das competências, nas quais, segundo Duarte, se privilegia o "conhecimento tácito que se forma na ação, no pensamento que acompanha a ação" (DUARTE, 2010, p. 43):

Desse modo, aprender a pensar e a tomar decisões diante de situações práticas problemáticas e imprevisíveis seria um dos maiores senão o maior objetivo da 
formação de professores. E o maior objetivo do trabalho do professor seria contribuir para que seus alunos também aprendam a pensar e a resolver problemas postos por suas práticas cotidianas. Em suma, tudo gira em torno ao aprender a aprender e ao aprender fazendo [p. 43].

As "pedagogias do aprender a aprender", segundo Derisso, mudam o "foco da aprendizagem pela transmissão e centrada no professor para a aprendizagem baseada na experiência e na descoberta decorrente dessa" (DERISSO, 2010, p. 56), exaltando o método do ensino-aprendizagem e secundarizando a definição do objeto a ser conhecido (p. 60). Para Duarte, o lema "aprender a aprender" "é exatamente o esvaziamento do trabalho educativo escolar, transformando-o num processo sem conteúdo" (DUARTE apud FRANCIOLI, 2010, p. 149). Masschelein e Simons veem nessa situação mais uma estratégia para se domar a escola, reduzindo-a "a uma instituição prestadora de serviço para o avanço da aprendizagem e, portanto, para satisfazer as necessidades individuais de aprendizagem e aperfeiçoar resultados individuais de aprendizagem" (MASSCHELEIN e SIMONS, 2013, p. 157).

Hannah Arendt afirmava, já em 1954, que "a Pedagogia transformou-se em uma ciência do ensino em geral a ponto de se emancipar inteiramente da matéria efetiva a ser ensinada" (ARENDT, 2011, p. 231), fruto de um movimento que teria se originado sob a influência da Psicologia moderna e dos princípios do Pragmatismo. Segundo Arendt, nesta perspectiva filosófica,

só é possível conhecer e compreender aquilo que nós mesmos fizemos, e sua aplicação à educação é tão primária quanto óbvia: consiste em substituir, na medida do possível, o aprendizado pelo fazer. O motivo porque não foi atribuída nenhuma importância ao domínio que tenha o professor de sua matéria foi o desejo de levá-lo ao exercício contínuo da atividade de aprendizagem, de tal modo que ele não transmitisse, como se dizia, "conhecimento petrificado", mas, ao invés disso, demonstrasse constantemente como o saber é produzido [p. 232].

As críticas de Duarte e Arendt direcionadas ao "aprender fazendo" precisam ser contextualizadas quando a referência é o ensino das artes. Mario de Andrade observa que "existe, [...] dentro da arte, um elemento, o material, que é preciso por em ação, mover, para que a obra de arte se faça. [...] nos processos de movimentar o material a arte se confunde quase inteiramente com o artesanato" (ANDRADE, 1963, p. 10). A aprendizagem da arte passa, necessariamente, pelo fazer, por uma 
relação corporal com seus materiais, ou seja, pelo domínio da artesania. Richard Sennett, em seu livro $O$ artífice, a partir de uma perspectiva oriunda do pragmatismo americano, afirma que o pensamento arendtiano ao menosprezar o trabalho manual do artesão em favor do trabalho intelectual e abstrato, separando a mão da cabeça, separa também "o pensamento e o sentimento [que] estão contidos no processo de fazer" (SENNETT, 2009, p. 17). Para Sennett, a aprendizagem requer "uma compreensão melhor do processo através do qual as pessoas produzem coisas, um envolvimento mais materialista que o encontrado em pensadores como Arendt" ( $p$. 17).

É neste sentido que nos aproximamos das proposições de Ana Mae Barbosa para o ensino da Arte a partir da abordagem triangular, que envolva as experiências do fazer, do apreciar e do contextualizar. O que será discutido no terceiro capítulo deste trabalho é a ênfase que se dá a cada uma dessas ações no ensino da linguagem teatral no contexto escolar. As relações entre arte e artesanato serão retomadas na segunda parte do quarto capítulo, onde problematizamos os saberes dos mestres das culturas de tradição popular como parte da formação do Professor de Teatro em Alagoas.

Outra questão problemática presente na crítica realizada pelos pedagogos histórico-críticos se revela em sua rejeição à pedagogia multiculturalista. Esta se baseia naquele que seria, segundo Duarte, um princípio comum a todas as "pedagogias do aprender a aprender", a afirmação de "que a realidade humana seria constituída de fragmentos que se unem não por relações determinadas pela essência da totalidade social, mas sim por acontecimentos casuais, fortuitos e inacessíveis ao conhecimento racional" (DUARTE, 2010, p. 36). Com isto, para Duarte, essas pedagogias assumem uma perspectiva relativista do mundo, na qual, ao situar o sujeito cognoscente em um ponto de referência particular nega qualquer possibilidade de totalidade, comprometendo "a universalidade e a objetividade do conhecimento" (p. 37). Esse "relativismo cultural [incidiria] diretamente sobre o currículo escolar, acarretando sua fragmentação, podendo levar, no limite, ao seu desaparecimento" (p. 37).

Duarte afirma que a pedagogia multiculturalista ao defender o princípio da diversidade cultural e do respeito às diferenças age como uma espécie de cavalo de 
Troia, levando "para dentro da educação escolar o pós-modernismo com toda sua carga de irracionalismo e anticientificismo" (p. 44). Para Duarte, os saberes, mesmo que resultantes de relações sociais alienadas, devem se distinguir entre aqueles que foram superados historicamente, daqueles que "constituem decisivos avanços para a essência humana e devem ser considerados valores universais a serem preservados numa sociedade que supere o capitalismo" (p. 48). Nesta perspectiva, saberes vindos de uma racionalidade não cartesiana, não iluminista e, portanto, não científica, não devem ser vistos como conhecimentos próprios à educação escolar.

O que os histórico-críticos parecem não querer reconhecer é que seu próprio posicionamento e as críticas que derivam dele precisam ser relativizados. Para nós, seu ponto de vista tende a criar juízos de valor que desprezam outros saberes sob a chancela de "historicamente superados" ao distingui-los daqueles que se constituíram em "decisivos avanços" para a humanidade. Esse ponto de vista parece querer impor um ponto de fuga único no quadro de evolução da humanidade para o qual todas as linhas concorreriam, inclusive aquelas relacionadas à formação do sujeito, transformando a escola em instrumento para a realização de seu projeto de poder, o que será analisado mais a frente.

Por ora, cabe detectar que algumas das críticas dirigidas às "pedagogias do aprender a aprender" podem revelar características presentes no ensino da Arte na Educação Básica brasileira e que foram vistas como problemáticas no primeiro capítulo desta tese. A primeira trata da ausência de uma Base Nacional Comum Curricular (BNCC) centrada em conteúdos conceituais serializados, isto é, em objetos de estudo e práticas pertinentes ao universo das artes que não visem, necessariamente, ao desenvolvimento emocional e cognitivo dos estudantes e/ou à sua adaptação ao mundo como ele se apresenta. Frise-se que a atual discussão em torno da implantação de uma BNCC aparentemente persistirá na manutenção desta perspectiva que tende a centrar no aluno o processo de aprendizagem escolar, secundarizando o conhecimento de mundo. Neste sentido, a linguagem teatral tende a ser vista somente em seus aspectos expressivos e subjetivos, restringindo-se aos processos pedagógicos vividos pelo sujeito cognoscente, ou seja, "o conhecimento é um produto da atividade subjetiva" (DERISSO, 2010, p. 57). Despreza-se, dessa maneira, a possibilidade de encontro com o outro, o diferente, e com aquele 
conhecimento intrínseco às próprias linguagens artísticas e aos objetos de arte em si.

Uma segunda característica refere-se à predominância de pedagogias e metodologias de ensino da linguagem teatral que privilegiam o fazer em detrimento do aprendizado da leitura e do estudo das manifestações teatrais existentes no mundo, o que parece configurar uma tendência de se entender que teatro se aprende fazendo, inspiradas em um dos lemas do Pragmatismo na educação. Nessas pedagogias/metodologias a ênfase colocada na expressão dos alunos e no desenvolvimento de suas subjetividades deixa em segundo plano o estudo, a leitura e até mesmo a prática da multiplicidade de formas teatrais criadas pela humanidade.

Estas questões, assim como outras referentes a pedagogias cujos processos de aprendizagem objetivam o desenvolvimento emocional dos estudantes e não sua formação como sujeito emancipado ou aquelas que se baseiam na solução de problemas serão enfrentadas de maneira mais extensa no terceiro capítulo deste trabalho.

\subsubsection{Sobre a crítica à pedagogia histórico-crítica}

A pedagogia histórico-crítica defende a necessidade de se ensinar a criança, sendo a escola o lugar em que o ensino deve ocorrer de maneira sistematizada, "porque na escola a criança não aprende o que sabe fazer sozinha, mas o que ainda não sabe e lhe vem a ser acessível em colaboração com o professor e sob sua orientação..." (VIGOTSKI apud FRANCIOLI, 2010, p. 155). É preciso, pois, socializar aqueles saberes produzidos historicamente pela humanidade através de uma atividade sistemática de apropriação do conhecimento. Para Demerval Saviani, "o povo precisa de escola para ter acesso ao saber erudito, ao saber sistematizado e, em consequência, para expressar de forma elaborada os conteúdos da cultura popular correspondente aos seus interesses" (SAVIANI apud FRANCIOLI, 2010, p. 159). A educadora Ana Carolina Marsiglia procura elucidar o que seriam esses saberes eruditos a partir do pensamento de Vigotski: 
os conceitos espontâneos e científicos se influenciam mutuamente, mas se comportam diferentemente em tarefas idênticas, pois se formam, desenvolvem e dizem respeito a processos diversos. Afirma esse autor [Vigotski] que a apreensão dos conceitos científicos depende da aprendizagem, que tem "poderosa força orientadora" na formação dos conceitos. Isso porque os conceitos científicos ensinam aquilo que a criança não tem diante dos olhos, que vai além da experiência [MARSIGLIA, 2010, p. 115, grifos da autora].

Dessa maneira, na pedagogia histórico-crítica, a educação escolar deveria operar através da transmissão de conteúdos relevantes para a concretização de um projeto de sociedade delineado por Karl Marx, ou seja, o comunismo.

\begin{abstract}
Uma sociedade comunista deve ser uma sociedade superior ao capitalismo e para tanto ela terá que incorporar tudo aquilo que, tendo sido produzido na sociedade capitalista, possa contribuir para o desenvolvimento do gênero humano, para o enriquecimento material $e$ intelectual da vida de todos os seres humanos. Trata-se de superar os limites do lluminismo sem negar o caráter emancipatório do conhecimento e da razão; superar os limites da democracia burguesa sem negar a necessidade da política; superar os limites da ciência posta a serviço do capital sem, entretanto, negar o caráter indispensável da ciência para o desenvolvimento humano; superar a concepção burguesa de progresso social sem negar a possibilidade de fazer a sociedade progredir na direção de formas mais evoluídas de existência humana [DUARTE, 2010, p. 49].
\end{abstract}

Em que pese a pertinência das críticas direcionadas às "pedagogias do aprender a aprender", que operariam o conhecimento nos mesmos moldes que o mundo corporativo opera sobre o mercado de trabalho, a pedagogia histórico-crítica precisa ser problematizada quanto ao seu entendimento de "patrimônio cultural da humanidade" e à sua perspectiva teleológica, segundo a qual o comunismo seria o estágio superior a ser atingido pela sociedade humana. Nesta perspectiva única e totalizante a construção de uma sociedade ideal decorre de uma crença evolucionista e progressiva na qual a educação das novas gerações exerce papel fundamental. Para Hannah Arendt,

o papel desempenhado pela educação em todas as utopias políticas, a partir dos tempos antigos, mostra o quanto parece natural iniciar um novo mundo com aqueles que são por nascimento e por natureza novos. No que toca à política, isso implica obviamente um grave equívoco: ao invés de juntar-se aos seus iguais, assumindo o esforço de persuasão e correndo o risco do fracasso, há a intervenção ditatorial, baseada na absoluta superioridade do adulto, e a tentativa de produzir o novo como um fait accompli, isto é, como se o novo já existisse [ARENDT, 2011, p. 225]. 
Para que as novas gerações possam realizar o que foi programado pelas velhas gerações é preciso, pois, transmitir-lhes aqueles conhecimentos necessários que justifiquem o projeto dessa "nova sociedade". Essa transferência de conhecimentos entre gerações só pode ser feita através da persuasão, visto que seu objetivo não é o de abrir o mundo para o estudo, mas apresentá-lo sob um ponto de fuga único para o qual todas as linhas concorrem numa projeção inexorável do futuro. Para isso, é necessária a seleção de elementos do passado que sejam estruturantes para este "projeto de mundo", que devem ser preservados e transmitidos às novas gerações, o "patrimônio intelectual da humanidade", com a consequente deslegitimação daqueles conhecimentos que não se enquadrem nesta perspectiva, vistos como "superados historicamente".

Levando-se em consideração a valorização que a pedagogia histórico-crítica faz do lluminismo e da razão cartesiana, da democracia e da ciência, e da negação do multiculturalismo na educação, fruto do "irracionalismo e anticientificismo pósmoderno", nas palavras de Duarte (2010, p. 44), pode-se aferir que o que se considera patrimônio cultural da humanidade nessa teoria seria aquele construído na perspectiva eurocêntrica do esclarecimento. O que, diga-se, é coerente com o próprio pensamento marxista construído a partir das maneiras de operar o conhecimento advindas da cultura europeia, como a própria razão cartesiana e o lluminismo. Assim, a transmissão de conhecimentos estratificados, selecionados como essenciais para a estruturação de uma nova sociedade projetada através de uma lógica racional-cartesiana seria função da escola, na visão dos pedagogos histórico-críticos. A aprendizagem, dessa maneira, deixa de ser uma experiência dialética da identidade do indivíduo em choque com a multiplicidade do mundo, pois a subjetividade dos alunos diante dos objetos de ensino apresentados possui pouco interesse nessa perspectiva pedagógica, talvez porque essa individualidade poderia colocar em questão a infalibilidade de um novo mundo dado a priori.

Torna-se importante, neste ponto, retomar a crítica que Adorno fez em defesa de uma educação baseada na experiência formativa contrária ao que ele chamou de "semiformação", que se basearia em um "conceito de racionalidade ou de consciência [...] apreendido de um mundo excessivamente estreito, como capacidade formal de pensar" (ADORNO, 1995, p. 115). Na leitura realizada por 
Wolfgang Leo Maar, Adorno estaria advertindo "contra os efeitos negativos de um processo educacional pautado meramente numa estratégia de 'esclarecimento' da consciência, sem levar na devida conta a formação social em que a educação se concretiza como apropriação de conhecimentos técnicos" (MAAR, 1995, p. 11).

Para Adorno, "a exigência que Auschwitz ${ }^{20}$ não se repita é a primeira de todas para a educação" (ADORNO, 1995, p. 119), o que, segundo Maar, coloca em xeque uma educação que desconsidera o conteúdo ético do processo formativo em função de sua determinação social:

Como pôde um país tão culto e educado como a Alemanha de Göethe desembocar na barbárie nazista de Hitler? Caminho tradicional para a autonomia, a formação cultural pode conduzir ao contrário da emancipação, à barbárie. O nazismo constituiria o exemplo acabado deste componente de dominação da educação, resultado necessário e não acidental do processo de desenvolvimento da sociedade em suas bases materiais [MAAR, 1995, p. 15].

Para Maar, Auschwitz seria, na perspectiva de Adorno, "parte de um processo social objetivo de uma regressão associada ao progresso, um processo de coisificação que impede a experiência formativa, substituindo-a por uma reflexão afirmativa, autoconservadora, da situação vigente" (p. 22). Sem abdicar da "vinculação, necessária embora não automática, entre esclarecimento e liberdade, entre razão e emancipação" (p. 20), a educação contra a barbárie deve ser uma experiência formativa na qual o aprendizado se dá pela abertura total frente ao objeto e através do contato com o outro, o diferenciado. "A experiência é um processo auto-reflexivo, em que a relação com o objeto forma o sujeito em sua 'objetividade'. Neste sentido, a experiência seria dialética, basicamente um processo de mediação" (p. 24). O conteúdo dessa experiência implica na transformação do sujeito durante o processo de mediação, ou seja, tornar-se experiente e autônomo. "Para Adorno, o travamento da experiência deve-se à repressão do diferenciado em prol da uniformização da sociedade administrada, e à repressão do processo em prol do resultado, falsamente independente, isolado" (p. 25). Assim, segundo Adorno, "as

\footnotetext{
${ }^{20}$ Auschwitz foi o maior dos complexos de campos de concentração criados pelo regime nazista, nos quais prisioneiros de guerra, em sua maioria de origem judaica, eram condenados a trabalhos forçados, usados como cobaias para experimentos médicocientíficos e executados em câmaras de gás.
} 
tentativas de se contrapor à repetição de Auschwitz são impelidas necessariamente para o lado subjetivo" (ADORNO, 1995, p. 121):

Aquilo que caracteriza propriamente a consciência é o pensar em relação à realidade, ao conteúdo - a relação entre as formas e estruturas de pensamento do sujeito e aquilo que este não é. Este sentido mais profundo de consciência ou faculdade de pensar não é apenas o desenvolvimento lógico formal, mas ele corresponde literalmente à capacidade de fazer experiências, eu diria que pensar é o mesmo que fazer experiências intelectuais. Nesta medida e nos termos que procuramos expor, a educação para a experiência é idêntica à educação para a emancipação [p. 151].

A crítica à pedagogia multiculturalista aponta para o estabelecimento de um patrimônio cultural da humanidade em uma perspectiva limitada e eurocêntrica, que desqualifica outras formas de conhecimento como "irracionais". Trata-se de bloquear a possibilidade da experiência formativa na alteridade, diante do outro que me é diferente, o que faz da pedagogia histórico-crítica uma educação ideologizante, o que, para Adorno, consiste na

\begin{abstract}
tentativa de incutir nas pessoas uma falsa consciência e um ocultamento da realidade, além de, como se costuma dizer tão bem, procurar-se impor às pessoas um conjunto de valores como se fossem dogmaticamente positivos, enquanto a formação a que nos referimos consistiria justamente em pensar problematicamente conceitos como estes que são assumidos meramente em sua positividade, possibilitando adquirir um juízo independente e autônomo a seu respeito [p. 80].
\end{abstract}

Trata-se do estabelecimento de uma perspectiva totalizante, de um ponto de fuga único, de um cânone llustrado cujo contato com outras culturas, com algo efetivamente exterior ao "meu mundo", resulta em uma relação hierarquizada. Assim, quando a cultura do outro é vista como "superada historicamente" (atrasada, folclórica, popularesca, massificada, menor, simplória, inculta, não civilizada), sem que haja interesse por ela ou qualquer desejo de problematizá-la, perde-se a capacidade de referir-se às próprias representações que se faz desse outro externo. Perde-se a própria capacidade de emancipação intelectual. Uma educação ideologizante acaba por revelar-se uma educação heterônoma submetida a valores não questionáveis, oposta a uma educação que vê o sujeito como livre para reger-se a si mesmo, com autonomia. Para a filósofa Márcia Tiburi,

se o registro do conhecimento funciona pela negação do outro, o conhecimento nega a si mesmo. Sem o outro, o conhecimento morre. O enrijecimento é uma prova da morte 
do conhecimento que se torna cegueira ideológica. A ideologia é a redução do conhecimento à fachada, como que sua máscara mortuária. O conhecimento, que deveria ser um processo de encontro e disposição para a alteridade que o representa, sucumbe à sua própria negação [TIBURI, 2015].

Adorno afirma que "onde falta a reflexão do próprio objeto, onde falta o discernimento intelectual da ciência, instala-se em seu lugar a frase ideológica" (ADORNO, 1995, p. 62), o que o leva a concluir que "o êxito como docente acadêmico deve-se a ausência de qualquer estratégia para influenciar, à recusa em convencer" (p. 104), ou seja, a negação da persuasão nos/dos processos educativos.

Ao negar os saberes vindos de outras sociedades estranhas à civilização europeia, a teoria histórico-crítica alinha-se ao pensamento marxista mais ortodoxo para o qual outras formas de organização social, política e econômica não possuiriam as condições históricas necessárias para que o comunismo se apresentasse como a síntese e solução final para a evolução da humanidade. Assim sendo, toda produção cultural que não corresponda à perspectiva europeia e iluminista não seria significativa e não poderia ser considerada como um patrimônio da humanidade que deva ser transmitido às novas gerações através da educação escolar. Atualizando as palavras de Deleuze e Guattari, "o lluminismo recai no erro de substituir o conhecimento pela crença" (DELEUZE e GUATTARI, 1992, p. 72), como já haviam observado Adorno e Horkheimer em sua obra Dialética do esclarecimento (1985).

A negação da subjetividade e de formas de pensar não-cartesianas em uma perspectiva eurocêntrica que toma esse "conjunto de valores como dogmaticamente positivos" (ADORNO, 1995, p. 80) tende a ser ainda mais problemática quanto ao ensino da arte dentro da escola. A forma como a arte opera sobre o caos, emoldurando-o, pressupõe a inclusão também do inconsciente, de formas de pensar irracionais e anticientíficas rechaçadas pela pedagogia histórico-crítica. Jorge Coli afirma que o domínio da arte "é o do não-racional, do indizível, da sensibilidade: domínio sem fronteiras nítidas, muito diferente do mundo da ciência, da lógica, da teoria" (COLI, 1992, p.109). No fazer artístico, como observa Flavio Desgranges, "a matéria se movimenta e tira o sujeito da condição de quem só age voluntariamente. 
Há também um agir involuntário, um pathos sofrido, um gesto inconsciente que o tira da própria condição de sujeito" (DESGRANGES, 2012, p. 217).

Assim, ao colocar as condições históricas de produção do objeto como base de sua análise crítica, os pedagogos histórico-críticos tendem a procurar no objeto o que a teoria descreve. Dir-se-ia que é "colocar a carroça na frente dos burros", desprezando-se a fruição do objeto em favor de referências culturais já estabelecidas, o que demonstra o dogmatismo e o caráter ideologizante desta pedagogia.

O sentido teleológico da pedagogia histórico-crítica implica em um movimento evolutivo e, por que não dizer, baseado na crença em um progresso social que se sintetizaria em uma sociedade comunista. Ao valorizar uma narrativa única e totalizante essa pedagogia histórico-crítica não só nega a multiplicidade de narrativas e seu caráter fragmentário, como também toda a possibilidade das novas gerações em construir um novo mundo, visto que o futuro já estaria pré-determinado no passado. Ao que parece, essa perspectiva teleológica retiraria qualquer possibilidade de transformação do mundo, qualquer possibilidade de um futuro novo, pois este já teria sido delineado no passado, pelas velhas gerações.

\subsubsection{A politização da escola}

A escola estaria fadada, hoje, a cumprir o papel de coadjuvante em uma luta político-ideológica entre, para usar os termos de Duarte (2010, p. 48), uma concepção pragmatista e uma concepção marxista de prática social? O objetivo da escola seria o de se colocar a serviço da sociedade tal qual ela se apresenta, para manter o mundo como ele é, ou seria o de formar uma "vanguarda revolucionária" que transformaria o mundo naquilo que ele deveria ser? Ou a escola teria perdido mesmo seu sentido formativo incapaz de dialogar com o mundo atual e de competir com outros projetos educativos baseados nos avanços tecnológicos, como as mídias digitais, e estaria em vias de extinção, como propõem os defensores da desescolarização? 
Um olhar mais atento sobre o sentido da escola talvez possibilite outras perspectivas para se pensá-la hoje. Para o pensador marxista Antonio Gramsci, o problema da escola tradicional não estaria em seus modos pedagógicos, mas na exclusividade da educação somente para os filhos das classes dirigentes. Em suas palavras,

A escola tradicional era oligárquica já que destinada à nova geração dos grupos dirigentes, destinada por sua vez a tornar-se dirigente: mas não era oligárquica pelo seu modo de ensino. Não é a aquisição de capacidade de direção, não é a tendência a formar homens superiores que dá a marca social de um tipo de escola. A marca social é dada pelo fato de que cada grupo social tem um tipo de escola próprio, destinado a perpetuar nestes estratos determinada função tradicional, dirigente ou instrumental [GRAMSCI apud SALA, 2010, p. 89].

A escola pública brasileira, segundo a crítica dos pedagogos histórico-críticos, tem se voltado à instrumentalização das classes trabalhadoras através dos modos educativos das "pedagogias do aprender a aprender". Na perspectiva desses educadores a retomada dos modos de ensino da educação tradicional se constituiria em uma maneira de oferecer às classes trabalhadoras a mesma escola das classes dirigentes. Porém, parece-nos que o problema dessa "escola tradicional" defendida por Gramsci não está somente em sua origem oligárquica, mas nas suas formas de operar o conhecimento próprias das classes dirigentes. Pode-se afirmar que se as "pedagogias do aprender a aprender" tendem para a forma sem conteúdo (ou para os chamados "conteúdos significativos", que nada mais são do que formas de aprendizagem de ação no mundo), a pedagogia histórico-crítica, por sua vez, ao combater esse formalismo educacional, recorre aos modos pedagógicos tradicionais sem realizar a devida crítica ao quanto essas formas carregam em si conteúdos autoritários. Masschelein e Simons observam que

a escola, como uma "instituição moderna" - a forma que assumiu no século XVIII e começo do século XIX no Ocidente - é um exemplo da tentativa de dissipar a renovação... [...] Isso acontece ao se apresentar algo e, simultaneamente, deixar claro que "é assim que deve ser feito, e esses são os materiais de aprendizagem que devemos usar". Como instituição, a escola serve a um ideal predeterminado. [...]. A instituição priva a geração mais jovem do tempo e do lugar para praticar e experimentar o tempo livre - nega-lhe o tempo escolar - e a geração jovem é, subsequentemente, privada da oportunidade de realmente se tornar uma nova geração. Em vez disso, os jovens tornam-se (no máximo) atores da renovação imaginada por seus pais [MASSCHELEIN e SIMONS, 2013, p. 106]. 
Dessa maneira, sejam os adeptos do "aprender a aprender", sejam os histórico-críticos, suas propostas pedagógica se revestem de um caráter ideologizante com finalidades político-econômicas presentes nas formas de operar o conhecimento. Mas seria possível uma escola sem nenhuma ideologia?

Segundo Marilena Chauí,

Um dos traços fundamentais da ideologia consiste, justamente, em tomar as ideias como independentes da realidade histórica e social, de modo a fazer com que tais ideias expliquem aquela realidade, quando na verdade é essa realidade que torna compreensíveis as ideias elaboradas [CHAUÍ, 2004, p. 5].

Nesse sentido dificilmente a escola estaria livre de operações ideológicas, pois a ideologia é, para Chauí, um dos dois instrumentos de dominação, ao lado do Estado, que as classes dirigentes dispõem para manter seus privilégios (p.35), e a educação é um dos meios pelos quais essa classe distribui seus universais abstratos entre as classes exploradas. Nesta perspectiva da história vista como luta das classes na qual a sociedade civil não poderia ser concebida como um indivíduo coletivo conhecido como $A$ Sociedade (p. 29), as classes em luta pelo poder produziriam, incessantemente, suas ideologias, não sendo esta operação, em nosso ponto de vista, privilégio somente da burguesia.

A tentativa de fazer da educação das novas gerações um meio de produção e reprodução das ideias das classes dirigentes ou daquelas que queiram chegar ao poder faz com que essas propostas pedagógicas sejam ideologizantes, pois veem na escola, em particular, um mero instrumento político. Pois, se para Karl Marx, nas palavras de Chauí, "o ideólogo é aquele que inverte as relações entre as ideias e o real" (p. 11), ele pode agir nas diferentes trincheiras desta luta.

A perspectiva ideologizante para a educação escolar é rechaçada por Hannah Arendt, porque, para ela, a essência da educação é a natalidade, "o fato de que seres nascem para o mundo" (ARENDT, 2011, p. 223, grifo da autora). "O mundo no qual são introduzidas as crianças [...] é um mundo velho, isto é, um mundo preexistente, construído pelos vivos e pelos mortos, e só é novo para os que acabaram de penetrar nele" (p. 226) pelo nascimento. Assim, conforme dito anteriormente, iniciar um novo mundo com aqueles que são novos nele através da 
educação é um grande equívoco político, pois a política é uma ação entre iguais baseada na persuasão e esta igualdade na escola estaria comprometida diante da absoluta superioridade do adulto educado. Para Arendt,

pertence à própria natureza da condição humana o fato de que cada geração se transforma em um mundo antigo, de tal modo que preparar uma nova geração para um mundo novo só pode significar o desejo de arrancar das mãos dos recémchegados sua própria oportunidade face ao novo [p. 226].

As diversas pedagogias expostas acima sejam as alinhadas aos quatro pilares para a educação no século XXI da UNESCO, seja aquela baseada na teoria histórico-crítica, objetivam, as primeiras, a manutenção do mundo tal como ele se encontra, e a segunda, um novo mundo já projetado, ou seja, ambas retiram a possibilidade dos recém-chegados de criar um mundo realmente novo. Ambas comentem o equívoco de levar a educação para o campo da política e da persuasão ideológica, pois não consideram a relação desigual entre educadores e educandos ferindo o princípio de igualdade no qual se baseia a própria política.

Masschelein e Simons veem a politização da escola como outra forma de domar seu potencial de transformação do mundo, agindo contrariamente à sua origem democrática de disponibilizar a todos, igualitariamente, os conhecimentos e as habilidades criados pelo homem. "Os anos de escola são uma fonte de medo para todos os que procuram perpetuar o velho mundo ou para aqueles que têm uma clara ideia de como um mundo novo ou futuro pode parecer" (MASSCHELEIN e SIMONS, 2013, p. 10). São dois movimentos com sentidos opostos, um que demanda a reforma da escola e outro que busca restabelecer a escola tradicional:

Tais demandas estão sendo feitas a partir da perspectiva de que o sentido da escola, em última análise, se resume em otimizar o desempenho de aprendizagem (individual). Ao mesmo tempo, observamos também que mais e mais pessoas querem restabelecer a escola. Esses movimentos de "reescolarização" assumem, principalmente, uma atitude reparadora e tentam reinstalar a escola "clássica" ou "tradicional". No entanto, ambos os movimentos - os reformadores e os restauradores - veem a escola, essencialmente, como funcional, e ambos estão preocupados com a escola como um agente que contribui para um certo propósito (estimular a aprendizagem, desenvolver o talento, restaurar o aprendizado baseado na realização, dominar as habilidades, transmitir valores etc.). Eles se concentram, exclusivamente, nas características desse agente a partir da perspectiva de sua pretendida finalidade ou expectativas pré-formuladas [p. 19, grifos dos autores]. 
Nessa luta entre "reformistas" e "tradicionalistas" há um desejo em comum: cercear a ação da educação escolar em tornar público os conhecimentos e habilidades criados pelo homem, impedindo, assim, a renovação e a democratização (p.108). O problemático nessas tentativas de politização da escola é transformá-la, assim como a seus alunos, em instrumento e meio para a realização de reformas sociais.

Se pensarmos a cultura como forma de agir e pensar do homem no mundo é impossível abolir os aspectos ideológicos, ainda que conflitantes, dentro das instituições educacionais de uma comunidade. A ideologia está na escola porque a escola é feita por homens que pensam, e pensam a partir de suas perspectivas de mundo e de seus desejos de melhorar esse mundo. Porém, pode-se propor uma espécie de distinção escolar entre ideologia e pregação ideológica e, assim, limitar as tentativas de transformar a escola em instrumento na luta de classes pelo poder. Como instituição responsável pela formação das novas gerações e como um espaço educativo diferenciado é preciso alargar o sentido que a escola tem no mundo para além de uma visão meramente instrumental. Talvez possamos pensar a escola sob outra perspectiva que não se paute em sua função dentro da sociedade, ou seja, em suas ações, mas em seu sentido, no que realmente consiste a escola para a humanidade.

\subsubsection{A escola como transição ou como tempo livre}

O conflito entre "reformistas" e "tradicionalistas" se insere na crise profunda entre o mundo contemporâneo e a tradição, problematizada por Hannah Arendt, que vê no esfacelamento da tradição a perda da sabedoria. Nas palavras de Celso Lafer, trata-se da "dificuldade de discernir, num contexto, as classes de perguntas que devem ser feitas" (LAFER, 2011, p. 10). Para Arendt,

Sem tradição - que selecione e nomeie, que transmita e preserve, que indique onde se encontram os tesouros e qual seu valor - parece não haver nenhuma continuidade consciente no tempo, e portanto, humanamente falando, nem passado nem futuro, mas tão-somente a sempiterna mudança do mundo e o ciclo biológico das criaturas que nele vivem [ARENDT, 2011, p. 31]. 
Walter Benjamin (1994), ao se debruçar sobre a incapacidade dos combatentes da I Guerra Mundial, quando retornaram para suas casas, em contar o que fora este conflito, já alertava para a crescente dificuldade que a civilização europeia apresentava para compartilhar suas experiências. Esta incapacidade para contar histórias, para narrar eventos significativos revelava-se, ainda, na crescente influência dos meios de divulgação impressa, os jornais (news-paper, em inglês), voltados às "últimas notícias", ao que acontece no passado imediato, no dia anterior, no quase presente. O pathos do novo, a que nos referimos anteriormente, e a incompatibilidade inconciliável entre a narrativa e a informação não só demonstrava a morte da narração (OLIVEIRA, 2009) como também lançava o homem europeu (e sua civilização) na sempiterna mudança do mundo, a viver eternamente no aqui e agora do ciclo biológico, sem passado e sem a sabedoria da tradição.

A compreensão do sentido de ciclo biológico, para Arendt, passa pela distinção que a filósofa faz de labor e trabalho. Labor refere-se às necessidades biológicas da condição humana, ao território da vida, em suma, ao qual Arendt chama de território do animal laborens, inspirada em Karl Marx. Nas palavras da filósofa Ana Beatriz Gomes,

- labor com a sua natureza estritamente ligada à necessidade acaba por caracterizarse pela atividade que corresponde à experiência de completa ausência do mundo, no qual o corpo humano se volta para dentro de si mesmo e permanece preso ao seu metabolismo. Muitos homens, aliás, temem libertar-se do processo vital, pois consideram futilidade o que existe para além dele e preferem carregar o peso das necessidades básicas ao invés de permitirem-se conhecer outras instâncias de estar no mundo para além do labor [GOMES, 2012, p. 38, grifos da autora].

No labor, o homem trabalha para comer e come para trabalhar, em um movimento cíclico, caracterizado pela necessidade compulsória do consumo. Já o trabalho, território do homo faber, refere-se às atividades criativas: "O trabalho caracteriza-se pela vontade do homo faber (criador do artifício humano) em construir um mundo humano, através da criação que é precedida por um modelo, que carrega a ideia e a forma da construção em questão" (p. 38). Esse processo de criação caracteriza-se por sua finitude, ou seja, pressupõe um começo e um fim bem definidos, contrapondo-se ao ciclo biológico e de consumo do animal laborens. Os 
dois territórios, por vezes, se sobrepõem, seja dentro de um mesmo ser, seja na sociedade, causando, em geral, atrito, pois um quer construir e o outro quer consumir o construído. "A grande ameaça à cultura atualmente é que muitas obras produzidas no passado e no presente estão sendo consumidas como meras funções do processo vital da sociedade" (p.46). Para Arendt, é um erro fatal acreditar que uma sociedade de consumidores, ainda que consumidores de cultura, se tornará "mais cultivada" à medida que a educação desempenhe seu papel, pois tal sociedade é "possivelmente incapaz de defender um mundo e as coisas que pertencem exclusivamente ao espaço do aparecer no mundo, já que a sua [...] atitude de consumo, condena à ruína tudo aquilo em que toca" (ARENDT apud GOMES, 2012, p. 46).

As "pedagogias do aprender a aprender", ao secundarizarem o mundo como objeto de estudo e voltarem-se à adaptação ao mundo como ele se apresenta, e ao privilegiarem as necessidades emocionais, psicológicas e de desenvolvimento de talentos pré-existentes nos alunos, voltadas para sua interioridade, em detrimento da transmissão do patrimônio cultural da humanidade, parecem querer fixar o homem nessa eterna e cíclica mudança, em um ciclo biológico cuja resultante é a atual sociedade extremamente consumista em que vivemos. Ao contrário, a essência do trabalho está diretamente relacionada à esperança,

pois sempre que iniciamos algo que intitulamos de trabalho acreditamos que mudará de alguma forma a realidade com que estamos a nos deparar naquele momento. Independentemente da profissão realizada, está presente no homo faber a esperança na possibilidade de através do seu trabalho criar um mundo real que está estruturado em sua mente [GOMES, 2012, p. 39].

Arendt se filia, assim, à tradição marxista no que se refere à distinção entre o homem e o animal: "não é a razão, [...] até então o atributo máximo do homem, mas sim o trabalho, a atividade humana mais desprezada, aquilo que contém a humanidade do homem" (ARENDT, 2011, p. 49). Para Marx, o homem não seria um animal rationale, mas sim um animal laborens, o que o distinguiria seria sua capacidade de criar um mundo humano. O que Arendt faz é diferenciar o labor, necessidade vital, do trabalho, criador de mundos. Nessa perspectiva, o animal laborens perguntaria "Como?" e o Homo faber, "Por quê?". 
Richard Sennett discorda dessa divisão que pressupõe a ausência de pensamento nas atividades manuais desenvolvidas pelo Animal laborens argumentando que "as discussões sustentadas pelo produtor podem ocorrer mentalmente com materiais, e não com outras pessoas" e que "as pessoas que trabalham juntas certamente conversam a respeito do que estão fazendo" (SENNETT, 2009, p. 17). O filósofo justifica seu argumento citando inclusive o jovem Marx que "nos Gundrisse, apresentou a habilidade artesanal nos termos mais amplos possíveis: 'atividade criadora de formas'. Enfatizou que as relações individuais e sociais desenvolvem-se pela confecção de objetos físicos, permitindo o 'desenvolvimento completo do indivíduo'" (p. 40).

Para Sennett, a perspectiva assumida por Arendt tende a desprezar o processo de feitura dos objetos a partir do pressuposto de que a mente somente se ativaria após a realização do trabalho, o que the parece equivocado visto que "todo bom artífice sustenta um diálogo entre práticas concretas e ideias; esse diálogo evolui para o estabelecimento de hábitos prolongados, que por sua vez criam um ritmo entre solução de problemas e a detecção de problemas" (p. 20). Dessa maneira, o "ciclo biológico" apontado por Arendt como responsável pelo consumo desenfreado que levaria o mundo à ruína não se justificaria pela suposta voracidade do Animal laborens, mas, provavelmente, pela separação entre "a mão e a cabeça, a técnica e a ciência, a arte e o artesanato" (p. 30). Neste processo de alienação, "a cabeça é então prejudicada; o entendimento e a expressão ficam comprometidos" (p. 30). No ensino da arte, o "Por quê?" do Homo Faber precisa do "Como?" do Animal laborens para se concretizar, mas voltaremos a esse tema mais a frente.

Importa-nos agora ressaltar que a tentativa de se olhar "para trás" para se entender o sentido da escola detectada nas proposições marxistas dos pedagogos histórico-críticos através da valorização do patrimônio cultural da humanidade e do conhecimento conquistado pelas velhas gerações e, desse modo, fugir do "ciclo biológico" presente nas "pedagogias do aprender a aprender", também pode ser encontrada nas reflexões de Hannah Arendt sobre a tradição e na proposta de se reinventar a escola, de Masschelein e Simons. Esses educadores belgas definem a escola como "uma fonte de conhecimento e experiência disponibilizada como 'bem comum"' (MASSCHELEIN e SIMONS, 2013, p. 9), próxima, portanto, à definição 
dada pelos pedagogos histórico-críticos: "uma instituição cujo papel central é a socialização do conhecimento historicamente elaborado e acumulado pela humanidade" (SALA, 2010, p. 85).

O sentido da escola como lugar em que o conhecimento é socializado e transformado em "bem comum" filia-se ao pensamento político e educativo de Hannah Arendt (2011). Arendt ressalta dois aspectos da educação que podem servir para alargar o entendimento da escola no mundo atual: a escola como transição entre a família e o mundo, entre a vida privada e a vida pública, e a educação vista como uma atitude conservadora e necessária para a renovação do mundo.

Diante do fato da natalidade, isto é, de que o mundo se renova continuamente através do nascimento de novos seres humanos, a educação teria a função de participar e interferir na formação desses recém-chegados ao mundo. Assim, a criança "é um novo ser humano e é um ser humano em formação" (ARENDT, 2011, p. 235), o que, segundo Arendt, nos difere de outras formas de vida animais, pois nos relacionamos tanto com a vida como com o mundo.

Os pais humanos [...] não apenas trouxeram seus filhos à vida mediante a concepção e o nascimento, mas simultaneamente os introduziram em um mundo. Eles assumem na educação a responsabilidade, ao mesmo tempo, pela vida e desenvolvimento da criança e pela continuidade do mundo [p. 235].

À família, ou seja, o que se refere à esfera privada da vida caberia proteger as crianças para que nada de destrutivo Ihes aconteça da parte do mundo e prepará-las para sua inserção na esfera da vida pública, ao mesmo tempo que também deve se responsabilizar pela proteção do mundo diante do assédio do novo que cada nova geração carrega. À escola caberia preparar os jovens para o entendimento do mundo:

Normalmente a criança é introduzida no mundo pela primeira vez através da escola. No entanto, a escola não é de modo algum o mundo e não deve fingir sê-lo; ela é, em vez disso, a instituição que interpomos entre o domínio privado do lar e o mundo com o fito de fazer com que seja possível a transição, de alguma forma, da família para o mundo. Aqui, o comparecimento não é exigido pela família, e sim pelo Estado, isto é, o mundo público, e assim, em relação à criança, a escola representa em certo sentido o mundo, embora não seja ainda o mundo de fato [p. 238]. 
Portanto, o sentido da escola para Arendt é o de realizar a transição dos novos seres humanos em formação entre a família e o mundo, porém a escola não é o mundo e não pode ser confundida com ele. Cabe à escola apresentar o mundo aos recém-chegados, ainda não familiarizados com ele, para que cheguem "à fruição em relação ao mundo como ele é" (p. 239).

A perspectiva educacional proposta por Arendt pensa o mundo como objeto a ser apresentado, como conteúdo a ser apreendido pelas novas gerações, na qual a escola é vista como pré-política, ou seja, anterior à entrada na vida pública. A escola estaria no meio, no inter-meio entre o público e o privado, o que a afasta das "pedagogias do aprender a aprender" que procuram reproduzir as formas hegemônicas de pensar. Disseminadas nas relações de poder já estabelecidas dentro do sistema capitalista, essas pedagogias se inserem em uma perspectiva de manutenção do mundo tal qual ele se apresenta, pois essas formas de pensar reafirmam as estruturas do mundo ao não tomá-lo como objeto de estudo. Ao apreender somente as formas de operar no mundo restaria às novas gerações repetir indefinidamente as estruturas do mundo até sua derrocada final. É preciso, pois, ir além das formas de operar sobre o mundo e debruçar-se sobre seus conteúdos, suas aparências e suas estruturas.

O mundo como objeto a ser apresentado e apreendido pelo educando aproxima a perspectiva educacional de Arendt às teorias histórico-críticas, porém com uma diferença fundamental: para a pensadora alemã a educação deve ter uma atitude conservadora em relação ao mundo e não transformadora do mundo, pois cabe às novas gerações criar o novo e não implantar o que as velhas gerações chamam de novo.

Arendt faz uma clara distinção entre a atitude conservadora na educação e o conservadorismo político. Na educação é necessário conservar, proteger e abrigar alguma coisa, "a criança contra o mundo, o mundo contra a criança, o novo contra o velho, o velho contra o novo" (p. 242), por se tratar de um âmbito de relações entre adultos e crianças. No âmbito da política, que envolve iguais, uma atitude conservadora que aceita o mundo como ele é só pode levá-lo à ruína pelo tempo. 
O mundo, visto que feito por mortais, se desgasta, e, dado que seus habitantes mudam continuamente, corre o risco de tornar-se mortal como eles. Para preservar o mundo contra a mortalidade de seus criadores e habitantes, ele deve ser, continuamente, posto em ordem. O problema é simplesmente educar de tal modo que um por-em-ordem continue sendo efetivamente possível, ainda que não possa nunca, é claro, ser assegurado. Nossa esperança está pendente sempre do novo que cada geração aporta; precisamente por basearmos nossa esperança apenas nisso, porém, é que tudo destruímos se tentarmos controlar os novos de tal modo que nós, os velhos, possamos ditar sua aparência futura. Exatamente em benefício daquilo que é novo e revolucionário em cada criança é que a educação precisa ser conservadora; ela deve preservar essa novidade e introduzi-la como algo novo em um mundo velho, que, por mais revolucionário que possa ser em suas ações, é sempre, do ponto de vista da geração seguinte, obsoleto e rente à destruição [p. 243].

Desta maneira, Arendt afirma a necessidade de separar o âmbito da educação do âmbito da vida pública e política para que a escola realize a transição entre a família e o mundo. É preciso "uma compreensão bem clara de que a função da escola é ensinar às crianças como o mundo é, e não instruí-las na arte de viver" (p. 246). Essa separação, porém, não está isenta de tensões, como observa Adorno:

Uma escola aberta ao exterior sem qualquer restrição provavelmente também abriria mão dos aspectos de formação e de amparo. [...] Certamente, na medida em que as pessoas da escola não permitem interferências, o fechamento da escola sempre tende a se enrijecer, sobretudo face à crítica. [...] Seria necessário explicar que a escola não constitui um fim em si mesma, que o fato de ser fechada constitui uma necessidade e não uma virtude [ADORNO, 1995, p. 115].

Filiados ao pensamento de Arendt, Masschelein e Simons, por sua vez, o problematizam ao defenderem que a escola não seria um lugar de passagem ou de transição (entre o passado e o presente) nem um local de socialização (entre a família e o mundo), mas um lugar em suspenção: "Devemos ver a escola como puro meio ou centro. A escola é um meio sem fim e um veículo sem um destino determinado" (MASSCHELEIN e SIMONS, 2013, p. 37) e que precisa ser reinventada. Para se chegar a esse intento, visto que a escola é uma criação histórica que pode, portanto, desaparecer, é preciso "encontrar formas concretas no mundo de hoje para fornecer 'tempo livre' e para reunir os jovens em torno de uma 'coisa' comum, isto é, algo que aparece no mundo que seja disponibilizado para uma nova geração" (p. 11). 
Mais do que socializar os conhecimentos ou compartilhar o "bem comum", para Masschelein e Simons a escola é, antes de tudo, "tempo livre", ou seja, uma das traduções possíveis para a palavra grega skholé. Vista como uma característica radical, porém essencial à educação escolar,

a de que a escola oferece "tempo livre" e transforma o conhecimento e as habilidades em "bem comum", e, portanto, tem o potencial para dar a todos, independentemente de antecedentes, talento natural ou aptidão, o tempo e o espaço para sair de seu ambiente conhecido, para se superar e renovar (e, portanto, mudar de forma imprevisível) o mundo [p. 10, grifo dos autores].

Tempo livre, portanto, é um tempo não produtivo, que não está voltado à produção.

A escola, como uma questão de suspensão, implica não só a interrupção temporária do tempo (passado e futuro), mas também a remoção das expectativas, necessidades, papéis e deveres ligados a um determinado espaço fora da escola. Nesse sentido, o espaço escolar é aberto e não corrigido [p. 37].

As noções de "tempo livre" e de "bem comum" norteiam a defesa da escola e a proposta de reinventá-la feita por esses educadores, que incluem, ainda, a necessidade de alienação e de igualdade. A alienação, ou seja, o afastamento temporário do aluno de sua família, de seu ambiente social e da própria sociedade, para que o mundo possa lhe ser apresentado. Alienação que causa temor no poder vigente:

Desde a sua criação nas cidades-estado gregas, o tempo escolar tem sido o tempo em que o "capital" (conhecimento, habilidades, cultura) é expropriado, liberado como um "bem comum" para o uso público, existindo, portanto, independente de talento, habilidade ou renda. E essa expropriação radical, ou "tornar público", é difícil de ser tolerada por todos os que procuram proteger a propriedade [p. 15, grifo dos autores].

Sobre a igualdade, Masschelein e Simons afirmam que "talvez não haja nenhuma inovação humana mais habilitada em criar a igualdade do que a escola" ( $p$. 69) e que esta deve ser um ponto de partida prático dentro da educação escolar, que considera que "todo mundo é capaz", alinhados às propostas de Joseph Jacotot, presentes no livro $O$ mestre ignorante, de Jacques Rancière (2010). 
Mas o que seria a escola, a educação escolar? Qual sua singularidade em um tempo em que os ambientes de aprendizagem se multiplicam? O que faz de uma escola uma escola? Para Masschelein e Simons,

a escola consiste em expropriação, desprivatização e dessacralização, e, portanto, na radical - ousamos até dizer na potencialmente revolucionária - oportunidade de renovar o mundo. O que é oferecido na escola de igualdade é, essencialmente, para todos e ninguém em particular. Trata-se do bem comum e isso significa que a escola também tem uma espécie de dimensão comunista, se ainda podemos usar essa palavra. Comunista não como uma doutrina política, mas como o estado temporário de suspensão ou expropriação durante o qual, quando o mundo é aberto, a experiência de "ser capaz de" se torna possível [MASSCHELEIN e SIMONS, 2012, p. 120].

A escola em sua origem grega fornecia tempo livre a todos, mesmo àqueles que não podiam reivindicar esse privilégio em uma sociedade aristocrática, separando e retirando "os alunos para fora da (desigual) ordem social e econômica (a ordem da família, mas também a ordem da sociedade como um todo) e para dentro do luxo de um tempo igualitário" (p. 29).

Cria-se, dessa maneira, uma espécie de suspensão no tempo produtivo, oferecido a todos independentemente de sua origem e classe social e que está voltado à socialização de conhecimentos e habilidades produzidos pelo homem: "o material tratado em uma escola não está mais nas mãos de um grupo social ou geração particulares e não há nenhuma conversa de apropriação; o material foi removido - liberado - da circulação regular" (p. 32).

Masschelein e Simons apontam para a necessidade, portanto, de se voltar aos conteúdos, aos objetos de estudo, à cultura. O encontro entre professor e aluno é intermediado pela matéria; é ela quem os une; é ela o elo entre os dois. Ou seja, um ato de desprivatização e de desapropriação (p. 33) que transforma o conhecimento em bem comum a ser oferecido igualitariamente como ponto de partida, como pressuposição de que "todo mundo é capaz", tornando as coisas públicas e partilhadas.

A concreta personificação da distinção entre "tempo livre ou não destinado" e "tempo produtivo ou destinado" que dá origem à escola e a seus personagens caminha lado a lado com tornar visível a igualdade e tornar possível a capacidade de começar. A escola rejeita toda e qualquer noção de um destino predeterminado. É surda para a invocação de um destino ou de uma predestinação natural. A escola se baseia na hipótese da igualdade. Oferece o mundo como um bem comum, a fim de permitir a 
sua renovação através da formação de interesse e de curiosidade. A escola é, portanto, não só uma invenção democrática como também uma invenção comunista pelas quais o mundo não somente é transmitido, mas também libertado - a escola cria um "bem comum" [p. 156].

\subsection{A arte, a escola e os desafios da sociedade contemporânea.}

Anteriormente, neste trabalho, fez-se referência às expectativas criadas pela sociedade brasileira em encontrar soluções definitivas para problemas históricos que o país enfrenta. Argumentou-se que se espera que essas soluções definitivas, que, em geral, referem-se a problemas da esfera social da vida humana, venham de fora, ou seja, da esfera política, como a esperança nos ideais das leis para "corrigir" a educação, problematizada nos PCN-Arte, ou para melhorar os indicadores sociais do país através da escola pública integral. Trata-se de desejos e projeções para a vida do país justos e justificáveis, porém direcionados a formas de solução externas à sociedade, pois, aparentemente, não se acredita que a própria sociedade consiga atingir por si só as expectativas por ela criadas.

A escola é, assim, vista como o instrumento privilegiado para resolver os problemas sociais do país e, diante de seu inevitável fracasso, vira o alvo predileto daqueles que a responsabilizam pela "deseducação do povo brasileiro". Acima, problematizou-se a perspectiva instrumental da escola quando voltada para projetos políticos idealizados pelas velhas gerações por privarem os jovens de criarem um mundo verdadeiramente novo. Pode-se estender essa problematização para outros campos da esfera social como fez Hannah Arendt ao discorrer sobre a obrigatoriedade que a Suprema Corte dos Estados Unidos da América, em 1959, impôs às escolas públicas brancas dos estados do sul daquele país, até então segregacionistas, a aceitar alunos negros.

Diante de uma foto em que uma aluna negra deixa a escola sendo humilhada publicamente por alunos brancos que não aceitavam sua presença ali, na cidade de Little Rock, Arendt se pergunta se a escola seria o local apropriado para resolver esse problema social: 
A parte mais surpreendente de toda a história foi a decisão federal de iniciar o processo de integração, dentre todos os lugares, nas escolas públicas. Certamente não havia necessidade de muita imaginação para ver que isso sobrecarregaria as crianças, brancas e pretas, com a elaboração de um problema que os adultos por gerações se confessaram incapazes de resolver. [...] A fotografia me pareceu uma caricatura fantástica da educação progressista que, abolindo a autoridade dos adultos, nega implicitamente a sua responsabilidade pelo mundo em que puseram os filhos e recusa o dever de guiar as crianças por esse mundo. Chegamos ao ponto em que se solicita às crianças que mudem e melhorem o mundo? E pretendemos ter as nossas batalhas políticas travadas nos pátios das escolas? [ARENDT, 2004, p. 271].

O argumento de Arendt leva em conta não somente a ausência de ações da Suprema Corte que deveriam ser tomadas anteriormente a essa, tais como impedir que as legislações estaduais daquele país afrontassem os direitos humanos primordiais como o da livre união através do casamento inter-racial, mas também chama a atenção para o que seria uma confusão e sobreposição entre as esferas pública, social e privada da vida humana. Para Arendt, a esfera social é regida pela discriminação que seria uma extensão do direito à livre associação na qual as pessoas se relacionam de acordo com suas profissões, classes sociais, origens familiares, condições econômicas e, nesse caso, infelizmente, à semelhança da cor de suas peles. Guiados por padrões e regras objetivas é o caso dos sindicatos, clubes e associações congêneres nos quais a "discriminação tem maior validade do que o princípio da igualdade" (p. 274), que é a característica da esfera política da vida humana. Ressalte-se que serviços públicos de propriedade privada, aqueles "de que todos precisam para realizar os seus negócios e orientar a sua vida" (p. 275), mesmo que não pertençam estritamente à esfera política "estão claramente no domínio público em que todos os homens são iguais” (p. 275).

Além das esferas social e política, há uma terceira na qual convivemos com outras pessoas em nossa privacidade e que é regida pela exclusividade, pois aqui "escolhemos aqueles com quem desejamos passar a vida" (p. 275) guiados por suas singularidades e diferenças. A singularidade e a exclusividade da esfera privada por vezes entram em choque com a discriminação da esfera social e suportar essa discriminação deve ser, para Arendt, "um caso privado", individual (p. 276), ainda que protegido pela legislação pública. Ou seja, se por um lado os padrões sociais não podem vir a serem padrões legais, o que tornaria tirânica a sociedade - "o governo tem de assegurar que a discriminação social nunca cerceie a igualdade 
política, [e] deve também salvaguardar os direitos da pessoa agir como quiser dentro das quatro paredes de sua casa" (p. 277) -, por outro, "o governo não pode tomar legitimamente nenhum passo contra a discriminação social, porque o governo só pode agir em nome da igualdade - um princípio que não existe na esfera social" (p. 277).

A sobreposição das esferas privada, social e pública interfere no sentido e nas ações da escola em nossa sociedade. Segundo Arendt, o direito dos pais em criar seus filhos é um direito de privacidade que está sendo desafiado pela educação obrigatória, ou seja, "pelo direito do corpo político de preparar as crianças para o cumprimento de seus futuros deveres como cidadãos" (p. 279). Para ela, esse direito do Estado deveria restringir-se ao conteúdo da educação e não ao contexto da associação que se desenvolve com a frequência da criança à escola. "Para a própria criança, a escola é o primeiro lugar fora de casa em que ela estabelece contato com o mundo público que a rodeia e à sua família. Esse mundo público não é político, mas social" (p. 280). Sendo assim, "forçar os pais a mandar os filhos para uma escola integrada contra a sua vontade significa privá-los de direitos que claramente Ihes pertencem em todas as sociedades livres - o direito privado sobre seus filhos e o direito social à livre associação" (p. 280). Cabe lembrar que o sentido da escola para Arendt é o de realizar a transição entre a vida privada, da família, para a vida pública, do mundo, o que justificaria sua posição contrária à imposição, via legislação, da escola integrada racialmente feita pela Suprema Corte norteamericana.

Já para Masschelein e Simons, a escola deveria ser um momento de suspensão da própria vida pautado pelo princípio da igualdade. Não a igualdade necessária à esfera política que, baseada na persuasão, seria impraticável na relação assimétrica entre educando e educador, mas a igualdade que pressupõe, por princípio e como início do processo educativo e formativo, que "todos são capazes". Nesta igualdade todos partem juntos e do início, e as origens social e familiar são deixadas para fora da sala de aula, assim como a cor da pele e os possíveis talentos pré-existentes: "A escola e o professor permitem que os jovens reflitam sobre si mesmos, separados do contexto (antecedentes, inteligência, talentos, etc.) que os conecta a um determinado lugar" (MASSCHELEIN e SIMONS, 
2012, p. 34), seja a família, seja a grupos sociais. A escola em suspensão seria aquela que "cria igualdade precisamente na medida em que constrói o tempo livre, isto é, na medida em que consegue, temporariamente, suspender ou adiar o passado e o futuro, criando, assim, uma brecha no tempo linear" (p. 36). Tal princípio não significa que não possa haver diferenciação na escola, mas reafirma que "o que é problemático é a diferenciação imposta pela sociedade sobre a escola em nome de uma necessidade natural ou outra qualquer" (p. 71).

O problemático para a escola ainda que colocada sob diferentes perspectivas - em transição, mas parte da sociedade, para Arendt, e em suspensão, para Masschelein e Simons - é a visão na qual o aluno e a matéria de estudo se tornam meios para a solução de problemas que a sociedade não consegue resolver por si só. Os adultos delegam à escola e aos jovens problemas que eles próprios, adultos, se sentem incapazes para enfrentar. É o que se percebe quando se fala no ensino da Arte dentro da escola através do qual se espera que a sua simples inserção no currículo escolar possa criar uma sociedade mais sensível para as obras, processos e acontecimentos artísticos.

Os brasileiros se reconhecem de maneiras antagônicas quanto à sua cultura artística. Há aqueles que veem o povo brasileiro como criativo e esteticamente sensível, características que se revelam em nossa riquíssima arte popular, a qual, porém, não se constitui em matéria de estudo escolar ou, quando consegue se legitimar como conhecimento, na maioria das vezes é apresentada em uma perspectiva folclórica e/ou diluída pela indústria cultural. Outros dizem que "falta cultura" aos brasileiros, pois somos um povo que desconhece os fundamentos das linguagens artísticas e, por conseguinte, não somos capazes de fruir obras que exijam um conhecimento anterior, que se constituiria em uma espécie de bagagem cultural.

Relevando-se o que cada visão tem de discriminatória, para usar o termo com o qual Arendt caracteriza as relações sociais, o problemático aqui é se esperar que a escola resolva essa questão. No caso das manifestações artísticas da tradição ou de origem popular, o que se percebe que estas ainda acontecem em guetos. Guetos que podem se traduzir como espaços menos nobres das cidades como as periferias, mas também como manifestações folclóricas ligadas ao calendário de festejos do 
país. Dessa maneira, as escolas de samba só se apresentam como tal na época do carnaval, as quadrilhas durante as festas juninas, os moçambiques nos festejos em homenagem a São Sebastião e a Nossa Senhora do Rosário e assim por diante. Dificilmente estas manifestações populares conseguem se legitimar como arte e seus produtores como artistas de fato. Muitas vezes são rotuladas como "artesanais" que, na perspectiva de Richard Sennett, seria uma tentativa de desqualificar as formas de pensar contidas nessas produções. A dificuldade de legitimação se deve à discriminação que recebem, seja por ser gerada em uma cultura oral e que, portanto, não possuiria o domínio do alfabeto das artes, seja por ser vista como uma espécie de expressão puramente intuitiva que careceria de técnicas apuradas e de conhecimentos conquistados através do estudo.

Quanto a uma arte vista como "culta", letrada, fruto de técnicas adquiridas em anos de estudo, na maioria das vezes produzida por artistas que frequentaram as academias de arte (escolas de balé, dança, teatro, artes plásticas, conservatórios musicais) e que trabalham sobre materiais e através de formas artísticas legitimadas como patrimônio cultural, o panorama do país é desolador. É notória que a quantidade de teatros, bibliotecas, livrarias, salas de exposição e centros culturais no Brasil está muito aquém do que se imagina para que um país seja reconhecido como "culto". Fora das grandes metrópoles grupos de teatro, dança, música de câmara e orquestras enfrentam imensas dificuldades para se constituírem como tal devido à quase inexistência de espaços de ensaio, apresentação e exposição para as artes.

Ou seja, a sociedade espera que a escola resolva um problema que é dela, pois essa mesma sociedade, por um lado, tende a discriminar a arte popular e, por outro, não frequenta nem disponibiliza espaços para que a chamada arte erudita possa ser produzida e fruída. O problema tem duas instâncias: de um lado, a esfera privada e social não possui o hábito de frequentar e fruir arte a não ser aquela produzida pela indústria cultural, e do outro, a esfera política não investe na arte, seja através da construção de teatros, museus, bibliotecas, espaços de formação e centros culturais, seja por meio de incentivos aos artistas já estabelecidos ou à iniciação dos jovens. 
Adorno observa que a sobrevivência da humanidade passaria, necessariamente, por sua desbarbarização o que seria o objetivo da escola, porém isso só pode ser realizado a partir da sociedade:

Não se deve esquecer que a chave da transformação decisiva reside na sociedade e em sua relação com a escola. Contudo, neste plano, a escola não é apenas objeto. [...] Enquanto a sociedade gerar a barbárie a partir de si mesma, a escola tem apenas condições mínimas de resistir a isso [ADORNO, 1995, p. 116].

\subsection{Professor ou arte educador?}

À dificuldade de entendimento da educação escolar e, por conseguinte, da finalidade do ensino das linguagens artísticas neste contexto soma-se ainda a multiplicidade de papéis e identidades dos arte educadores com relação ao caráter do exercício de sua atividade profissional. O educador da área de arte se identifica fora do contexto escolar de acordo com os múltiplos papéis que exerce: professor de Arte, arte educador, artista educador, docente artista, artista docente, formador, mediador, facilitador, orientador, oficineiro, educador em arte e outras denominações, muitas ao sabor das modas ou do mercado. Até mesmo o presente trabalho se ressente de precisão na escolha do termo apropriado para a qualificação do profissional da educação em arte e de arte. Inicialmente por tratar de problemas específicos ao contexto escolar a escolha recaiu em duas qualificações principais, na identidade escolar como Professor de Arte e na identidade de formação como Professor de Teatro. Neste capítulo se privilegiou o uso genérico de arte educador, porém, em algumas vezes, foram apostos os termos professor de Arte, formador desse professor e pesquisador de pedagogias da arte querendo-se, com isso, abarcar todos aqueles que trabalham na perspectiva da pedagogia da arte nos contextos escolar e sociocultural. Assim, arte educador sugere a maior amplitude que se buscou no presente capítulo, pois abarcaria qualquer situação educativa relativa à arte.

A escolha por arte educador em lugar de professor de arte ainda que arbitrária decorre do predomínio de pesquisas acadêmicas no campo das ações socioculturais, principalmente se o objeto de pesquisa é o ensino do teatro - o que 
foi observado no início deste trabalho ${ }^{21}$-, o que faz com que, muitas vezes, essa perspectiva se sobreponha ao contexto escolar. Assim, ainda que a designação professor seja utilizada na escola, os papéis, as funções e os objetivos desse educador que atua no ensino escolar muitas vezes se confundem com aqueles vindos da ação sociocultural.

A transferência de modos pedagógicos das ações socioculturais para o ambiente escolar sem a devida contextualização parece acarretar alguns problemas de identidade do professor que podem ser observados nas várias denominações que o educador de arte e em arte recebe ou se reconhece. Desconheço a existência de estudo que tenha se voltado para as diversas designações que esse educador recebe nas atividades de ação sociocultural e quais seriam os motivos para essa diversidade. Assim, proponho uma possibilidade de entendimento baseada, sobretudo, nos quase trinta anos de experiência profissional que possuo na área com o objetivo de problematizar essas designações presentes na ação sociocultural quando seu caráter educativo é transferido para o contexto escolar.

Aparentemente, existem duas perspectivas para se criar essas denominações. Uma busca um termo que designe com precisão a formação artística do educador. Se na década de 1980 a designação arte educador possuía livre trânsito na área perto do final do século passado começou-se a ouvir o termo artista educador. Os defensores da mudança, ou da diferenciação, argumentavam que eles não eram educadores, mas estavam educadores; eram artistas que exerciam atividades educativas, mas sem formação específica em educação através de graduações em pedagogia ou em licenciaturas. O desejo de se verem reconhecidos antes como artistas do que como educadores revela o caráter que imprimiam em suas atividades formativas que privilegiava a arte e seus próprios modos pedagógicos. Ainda que o objetivo das aulas que ministrassem não fosse, necessariamente, a profissionalização dos participantes nas linguagens artísticas propunha-se uma experiência educativa semelhante àquelas próprias à formação no ofício artístico e/ou da criação artística.

\footnotetext{
${ }^{21}$ Ver páginas $25-27$.
} 
José Carlos Libâneo (1998) problematiza essa perspectiva na educação escolar citando o estudo de António Nóvoa, Formação de professores e profissão docente, no qual este educador apresenta as relações possíveis no exercício do magistério na coexistência de três tipos de saberes:

o saber da experiência (dos professores), o saber dos especialistas (sociólogos, psicólogos, pedagogos) e o saber das disciplinas específicas. A tendência hoje seria de uma ligação entre o saber dos especialistas e o saber das disciplinas, com a consequente desvalorização do saber do professor [LIBÂNEO, 1998, p. 44, em nota de rodapé].

A defesa da arte e do saber dos artistas-especialistas privilegiando-os ante 0 saber da experiência educativa dos professores parece ser o motivo dessa e de designações semelhantes, como a recente artista docente que procura designar aqueles professores de cursos superiores de arte que seriam, antes de educadores e formadores, artistas. Tendência que corresponde à observação que Libâneo faz sobre o crescente desinteresse pelo magistério que se refletiria, segundo esse educador, também na ausência de pesquisas sobre questões do ensino e da sala de aula nas universidades do país:

Ou seja, a desvalorização econômica e social do magistério, além de comprometer o status social da profissão, também retira o status acadêmico dos campos de conhecimentos que the correspondem, tomando o ensino uma linha de pesquisa menos "nobre". Não é casual, por exemplo, a pouca valorização dos cursos de licenciaturas nas universidades e a insuficiência de pesquisas nesse campo [p. 42].

A outra perspectiva para as designações parece vir da necessidade de se explicitar os modos pedagógicos com os quais se estabelecerá a atividade formativa, ou seja, qual será o nível de atuação do educador e o que se projeta para a atuação dos participantes. Essas designações são utilizadas por diversos profissionais que exercem atividades educativas fora do contexto escolar não sendo, portanto, exclusivas dos arte educadores. Por meio de definições básicas pode-se apontar, entre tantos, o mediador como aquele que atuará na mediação entre o educando e a matéria de estudo; o orientador que conduz o processo de aprendizagem; o facilitador, aquele que, como bem diz o nome, irá facilitar o acesso do educando à matéria de estudo também utilizando-se de estratégias de aprendizagem. São termos que possuem um caráter mais adjetivo que substantivo. 
Nestes as designações evidenciam o protagonismo do educando no processo de aprendizagem em um tipo de ação pedagógica na qual o educador parece querer ser imperceptível, assim como suas estratégias, pelo menos no que concerne à sua qualificação educativa. Esta perspectiva se insere nas "pedagogias do aprender a aprender" nas quais os modos pedagógicos seriam, assim, mais relevantes do que a objeto de aprendizagem, isto é, a arte.

A divisão em dois grupos atende mais à necessidade de entendimento do fenômeno do que uma correspondência direta com a realidade, pois é comum encontrar-se, por exemplo, artistas educadores que dizem trabalhar sob uma perspectiva de mediação ou de orientadores que se colocam como artistas. O que se percebe em atividades educativas na esfera da ação sociocultural é que a existência de tantas identificações parece apontar para uma espécie de esvaziamento do termo professor, que pode significar até mesmo uma rejeição a ele. Quando os modos pedagógicos da ação sociocultural são transpostos para a escola sem a necessária contextualização essa negação também pode acontecer no ambiente escolar. A rejeição ao termo professor pode ser detectada, por exemplo, na defesa que Isabel Marques e Fábio Brazil fazem da valorização daqueles profissionais que possuem o que eles chamam de "talento híbrido", o artístico e o pedagógico. Subjacente à valorização há uma crítica ao que seria, para eles, o papel do professor na escola tradicional:

Ou seja, é importantíssimo que o professor assuma também, sem susto e sem medo, sua função de artista, de produtor, de pesquisador e de apreciador/leitor de arte. Esta é uma das grandes riquezas a serem vividas e discutidas com os estudantes. É vital que o professor de Arte torne-se um professor/artista, um artista/docente, e não um mero passador de técnicas ou informações, um reprodutor de sequências ingênuas [MARQUES e BRAZIL, 2014, p. 54].

Se "mero passador de técnicas" parece referir-se ao artista sem formação pedagógica e "mero passador de [...] informações" ao professor sem formação artística, chama a atenção o uso do verbo "passar" como modo pedagógico associando-o à ideia da reprodução em contraposição à criação. Talvez o desgaste do termo professor vindo de fora do contexto escolar se deva, historicamente, ao questionamento dos próprios processos educativos escolares criticados acima, quando a figura do professor que ensinava através da transmissão de 
conhecimentos em aulas expositivas ficou ligada à imagem da chamada escola tradicional. A crítica à educação tradicional realizada por diversas correntes pedagógicas ao longo do século XX visava, entre outros, desqualificar esses modos pedagógicos de transmissão alegando-se que nesse processo educacional os alunos seriam passivos, meros receptáculos de conteúdos externos à sua experiência de vida. É o que Paulo Freire (2006) chamou de ensino bancário, ou seja, uma ação educativa em que o professor deposita seu conhecimento no aluno. Ao se questionar os paradigmas da educação tida como tradicional essa crítica se voltou contra o predomínio que a transmissão de conhecimentos possuía sobre os processos subjetivos de aprendizagem resultando, em muitos casos, no ataque a qualquer pretensão de ensino que fizesse uso de estratégias como aulas expositivas e explicativas.

Libâneo defende que os professores devem desenvolver "novas atitudes docentes diante das realidades do mundo contemporâneo" (LIBÂNEO, 1998, p. 13) como forma de resistência a um eminente fim da própria profissão projetado já no título de seu livro, Adeus professor, adeus professora? - Novas exigências educacionais e profissão docente (1998). Segundo esse educador, "em face dessas novas realidades [...] a escola precisa deixar de ser meramente uma agência transmissora de informação e transformar-se num lugar de análises críticas e produção da informação" (p. 11). Observe-se que para Libâneo assim como para os defensores das "pedagogias do aprender a aprender" a escola tradicional é vista meramente como transmissora de informação e não de conhecimentos, e que caberia à nova escola e a seus professores capacitar o aluno para que este produza informação tornando-se "sujeito de seu próprio conhecimento" (p. 12).

Trata-se, assim, de capacitar os alunos a selecionar informações mas, principalmente, a internalizar instrumentos cognitivos (saber pensar de modo reflexivo) para ascender ao conhecimento. A escola fará, assim, uma síntese entre a cultura formal (dos conhecimentos sistematizados) e a cultura experienciada. Por isso, é necessário que proporcione não só o domínio de linguagens para busca de informações, mas também para a criação da informação [p. 12].

Porém, nessa perspectiva educativa do "aprender a aprender" defendida por Libâneo e ao contrário do que inicialmente se pretendia, segundo Alexandre Freitas, "o professor, quase sempre, tem sido significado como um indivíduo passivo, um 
executor prático das propostas previamente determinadas, reduzindo o saber docente ao 'saber fazer', ou seja, aos procedimentos relacionados com a transmissão" (FREITAS apud FERREIRA, 2007, p. 18), na perspectiva dos pedagogos histórico-críticos. Já o aluno, antes visto como um receptáculo vazio a ser preenchido, um ser passivo diante de sua própria formação, passou a ser visto como o centro e o protagonista do processo educativo. A radicalização dessa perspectiva fez com que muitos educadores ao propor estratégias de aprendizagem rechaçassem os modos educativos vindos da escola tradicional. Nessa mudança radical o sujeito da aprendizagem passou a ser exclusivamente o aluno e o verbo ensinar associado ao ofício do professor sofreu um enorme desgaste, bem como o próprio termo professor fora do contexto escolar.

O conflito entre pragmáticos e histórico-críticos, entre progressistas e conservadores, é visto por Masschelein e Simons, nesse caso, como um conflito entre reformistas e restauradores. Os primeiros procuram "otimizar o desempenho de aprendizagem (individual)" (MASSCHELEIN e SIMONS, 2012, p. 19), enquanto os segundos assumem "uma atitude reparadora e tentam reinstalar a escola 'clássica' ou 'tradicional'” (p. 19), sendo que ambos os grupos veem a escola em uma perspectiva funcional, "como um agente que contribui para um certo propósito (estimular a aprendizagem, desenvolver o talento, restaurar o aprendizado baseado na realização, dominar as habilidades, transmitir valores, etc.)" (p. 20). Dessa maneira, o papel da escola para esses educadores fica reduzido a um "ambiente de aprendizagem", colocando em xeque o próprio sentido da escola:

Quando a aprendizagem se reduz à produção de resultados de aprendizagem; quando a produção de resultados de aprendizagem se torna, simplesmente, uma descrição diferente para a conversão do potencial em competências; quando existem inúmeros caminhos de aprendizagem formal e informal e ambientes de aprendizagem que tornam possível esse processo de produção - qual é, então, o papel da escola? [p. 20].

Para esses educadores a escola como "tempo livre" que retira os jovens para fora da ordem social e econômica com o intuito de disponibilizar os bens comuns da humanidade como objetos de estudo não seria mais necessária nesse caso, pois os ambientes de aprendizagem virtual e as tecnologias de informação e comunicação "permitem direcionar a aprendizagem diretamente sobre o aluno individual" (p. 22). 
Se o que caracteriza a escola é o oferecimento desse tempo igualitário não se pode reduzi-la à pragmática transferência de conhecimento ou o desenvolvimento de talentos.

Masschelein e Simons defendem que a profanação de um saber e a suspensão do tempo, do espaço e de expectativas "tornam possível abrir o mundo na escola e que ele é, de fato, o mundo (e não necessidades ou talentos individuais de aprendizagem) que está sendo revelado" (p. 45). Assim a formação que a escola propicia "tem a ver com a orientação dos alunos para o mundo como ele é construído para existir no sujeito ou na matéria" (p. 47) e não com a aprendizagem:

A aprendizagem envolve o fortalecimento ou ampliação do eu já existente, por exemplo, por meio da acumulação de competências ou da expansão da base de conhecimento do indivíduo. Aprender, nesse sentido, implica uma extensão do próprio mundo da vida do indivíduo, acrescentando algo. $O$ processo de aprendizagem continua a ser introvertido - um reforço ou uma extensão do ego, e, portanto, o desenvolvimento da identidade. Na formação, no entanto, esse eu e o mundo da vida do indivíduo são colocados em jogo constante desde o início. A formação envolve, assim, sair constantemente de si mesmo ou transcender a si mesmo - ir além do seu próprio mundo da vida por meio da prática e do estudo [p. 49].

Para Masschelein e Simons existe uma diferença substancial entre aprendizagem e formação: a aprendizagem é individual, introvertida, voltada para o desenvolvimento da identidade, enquanto a formação é extrovertida colocando a própria identidade em crise. Em resumo, a escola se caracteriza por seu compromisso com a formação enquanto orientação para o mundo e não como "um campo de treinamento para aprendizes" (p. 43). Quando algo se torna parte do mundo também se torna um inter-esse, ou seja, "algo que não é nossa propriedade mas que é compartilhado entre nós" (p. 50), que nos leva a estudar, pensar e praticar:

Leva-nos para fora de nós mesmos. [...] Naquele momento, os alunos não são indivíduos com necessidades específicas que escolhem onde eles querem investir seu tempo e energia; eles são expostos ao mundo e convidados a se interessarem por ele; um momento em que a verdadeira comum-icação é possível. Sem um mundo, não há interesse nem atenção [p. 52, grifo dos autores].

Na perspectiva sugerida por Masschelein e Simons os métodos de ensino não deveriam somente "facilitar a aprendizagem" ou "transferir conhecimentos", mas, principalmente, gerar interesse no aluno quando apresentam o mundo: “Um método 
de ensino deve, constantemente, ser conectado ao mundo da vida dos jovens, porém, exatamente para removê-los de seu mundo de experiência" (p. 57), isto é, tirá-los de suas experiências de vida nas esferas social e familiar, suspendendo a ideia de um tempo e de um espaço produtivos, e tratá-los como iguais. Nesse processo igualitário o que interessa é aquela experiência que se refere ao ponto de partida fazendo com que os métodos e tecnologias de ensino permitam "a experiência de estar envolvido em prática e estudo interessantes" (p. 58), mas não em sua fabricação. O método de ensino escolástico deve fazer com que as experiências de fazer e aprender sejam possíveis.

Questões que engajam e apresentam o mundo aos alunos livres de um tempo privatizado, assim como também fazem algumas ferramentas da escola tradicional como a disciplina, a lousa e o livro. A monografia de conclusão de curso de Amanda Tavares Dias (2012), licenciada em Artes Cênicas pela Escola de Comunicações e Artes da Universidade de São Paulo, narra de forma exemplar a "descoberta" dessa tecnologia escolar e sua importância ainda hoje dentro da sala de aula.

Tendo como objeto de pesquisa e análise as aulas de Arte que ministrara em escolas públicas da cidade de São Paulo, Amanda Dias relata que ao preparar suas primeiras aulas no Ensino Fundamental II buscara referência nos jogos teatrais de Viola Spolin, sobretudo em seu livro Jogos Teatrais na sala de aula - um manual para o professor, "porque acreditava que esses jogos seriam mais pertinentes ao caso" (DIAS, 2012, p. 27). Tal crença talvez se deva à grande difusão existente no país de metodologias de iniciação à linguagem teatral, principalmente em ações socioculturais, que operam através de jogos. Fortemente influenciadas pelas perspectivas educacionais da aprendizagem e da resolução de problemas, essas metodologias de ensino se utilizam das experiências da vida familiar e social dos alunos como ponto de partida ou de chegada em seus processos formativos (mais à frente, se fará a abordagem dessas metodologias ligadas à área do Teatro Educação e suas possíveis implicações quando adotadas no contexto escolar).

Diante da recusa dos alunos de diversas turmas em jogar até mesmo o "par ou ímpar", Amanda Dias procurou outras estratégias e jogos, "mas a dificuldade em abrir espaços físicos e sensíveis na sala de aula era reincidente" (p. 29): 
Já constatada a dificuldade de trabalhar jogos com os alunos, me pareceu bastante necessário encontrar alguma outra maneira de instaurar aos alunos um estado de escuta, de silêncio, de organização de vozes, que são elementos importantes em um processo educacional porque impedem que as palavras sejam jogadas como bombas no espaço e fazem com que as palavras ditas encontrem ouvidos atentos [p. 30].

A licenciada mudou de estratégia e levou para as aulas seguintes um texto dramático, ou seja, alguma coisa, algo em comum em torno do qual poderia despertar o interesse dos alunos. Para introduzir o "novo" elemento em aula usou a estratégia de dirigir perguntas aos alunos, anotando na lousa suas respostas:

Era impressionante a capacidade da lousa em chamar a atenção dos alunos. Ao encostar o giz naquele quadro verde os alunos já começavam a se organizar melhor. Tive a mesma constatação na escola onde trabalho atualmente. A lousa é capaz de estabelecer e determinar qual é o lugar do aluno e qual é o lugar do professor, estes dois, tendo a lousa como objeto de comunicação [p. 28 , em nota de rodapé e grifos da autora].

Uma disciplina de estudo é instaurada na sala de aula através de duas ferramentas, o livro e a lousa, as quais pressupõem regras a serem seguidas, determinando o momento de atenção e de escuta. Para Masschelein e Simons, "as regras da escola não são regras para a vida (para viver a vida boa) e não são regras políticas (padrões ou leis para a ordem/ordenar a sociedade)" (MASSCHELEIN e SIMONS, 2012, p. 64). Na sequência, enquanto o livro com o texto dramático era passado entre os alunos, Amanda conversava um pouco sobre a estrutura daquele texto como a presença de rubricas e a divisão em diálogos, até o livro retornar à sua mão. "Surpreendentemente, todo o tempo da explicação anterior à leitura era acompanhado com tranquilidade pelos alunos, com poucos momentos de dispersão" (DIAS, 2012, p. 29).

O relato de Amanda Dias parece ser um claro indicador da necessidade de se diferenciar os ambientes educativos da escola em relação ao das ações socioculturais. Inicialmente, observa-se a recusa dos alunos para o jogo, fato que dificilmente ocorre em atividades educativas realizadas fora da educação escolar nas quais os participantes optam pela presença e aceitam as formas de ensino e aprendizagem propostas. No ensino curricularizado parece que algumas tecnologias tradicionais ainda fazem sentido, como a lousa, o livro e, por conseguinte, a palavra escrita como legitimadores do saber. E, por fim, destaque-se a surpresa da jovem 
professora com a atenção dos alunos para suas explicações, isto é, para a tradicional aula expositiva em que a palavra do professor enquanto conhecedor do assunto é compartilhada com os alunos.

Não se trata aqui de condenar a escola que precisaria se libertar de suas formas de ensino tradicionais ou as formas de operar das metodologias de Teatro Educação em voga no país, mas de se entender qual é o sentido da escola e o que a diferencia das ações educativas socioculturais. O fato é que a transição direta dos modos pedagógicos vindos da ação sociocultural para a educação escolar sem a realização de uma transposição didática que leve em conta as diferenças e singularidades de cada um desses contextos parece concorrer para deslegitimar 0 ensino do Teatro dentro da escola, inclusive entre os alunos. Se o termo professor parece não ser aceito em muitas ações socioeducativas de arte e em arte fora da escola, no ensino curricularizado ele ainda é reconhecido, porém a restauração de sua legitimidade talvez necessite de estratégias tradicionais como o uso da palavra escrita, da lousa, do livro e da aula expositiva.

O desgaste do termo professor também pode ser de origem política, associado à crise da autoridade, segundo a análise de Hannah Arendt em seu ensaio O que é autoridade? (2011). Segundo a filósofa política, a partir do entendimento da perda progressiva de "experiências autênticas e incontestes comuns a todos" (ARENDT, 2011, p. 127), como indicava Walter Benjamin, em seu ensaio O narrador (1994), o conceito de autoridade entra em crise manifesta no começo do século XX em sua origem e natureza política. Porém Arendt observa que a crise também se espalhou em áreas pré-políticas, como a criação dos filhos e a educação,

onde a autoridade no sentido mais lato sempre fora aceita como uma necessidade natural, requerida obviamente tanto por necessidades naturais, o desamparo da criança, como por necessidade política, a continuidade de uma civilização estabelecida que somente pode ser garantida se os que são recém-chegados por nascimento forem guiados através de um mundo preestabelecido no qual nasceram como estrangeiros [ARENDT, 2011, p. 128].

Diante de tema tão controverso, Arendt procura definir a autoridade "tanto em contraposição à coerção pela força como à persuasão através de argumentos" ( $p$. 
129), pois a autoridade ao exigir obediência é contrária à ordem igualitária da persuasão e pode ser confundida com poder ou violência. Porém Arendt alerta: "onde a força é usada, a autoridade em si mesmo fracassou" (p. 129), o que daria origem ao autoritarismo. Assim é necessário o entendimento de que "a autoridade implica uma obediência na qual os homens retêm sua liberdade" (p. 144). A origem da crise da autoridade remontaria aos séculos XVII e XVIII, quando a razão e seu modo de operar privilegiado, a dúvida, se voltaram contra a tradição e a crença que garantiam a presença e a necessidade da autoridade no campo da política.

Para Arendt, a criação das crianças estaria no âmbito da casa, da família, na esfera privada da vida, e a educação seria a preparação das novas gerações para assumirem o governo da pólis, a preparação dos recém-chegados ao mundo, ainda estrangeiros nele, para lidar com os assuntos do mundo na esfera pública. Arendt considera o âmbito político como aquele em que os participantes são iguais, com direito a falar e a serem vistos, agindo uns sobre os outros com a finalidade da persuasão através de argumentos, o que difere do processo educacional que não poderia ser realizado entre iguais, daí colocar a educação na esfera pré-política:

No âmbito político tratamos unicamente com adultos que ultrapassaram a idade da educação propriamente dita, e a política, ou o direito de participar da condução dos negócios públicos, começa precisamente onde termina a educação. [...] Reciprocamente, em educação lidamos sempre com pessoas que não podem ainda ser admitidas na política e na igualdade, por estarem sendo preparadas para elas. [...] Dado que é fato ser a necessidade de "autoridade" mais plausível e evidente na criação e educação de crianças do que em qualquer outra parte. Eis porque é tão característico de nossa era querer erradicar até mesmo essa extremamente limitada e politicamente irrelevante forma de autoridade [p.160].

Neste sentido o professor, segundo Arendt, estaria autorizado pela família e pela sociedade a educar as crianças nas coisas do mundo, ou seja, "é de seu ofício servir como mediador entre o velho e o novo, de tal modo que sua própria profissão Ihe exige um respeito extraordinário pelo passado" (p. 244). Em uma época em que se vive sob o pathos do novo, o passado, a tradição e a experiência também estão permanentemente em crise:

O problema da educação no mundo moderno está no fato de, por sua natureza, não poder esta abrir mão nem da autoridade, nem da tradição, e ser obrigada, apesar disso, a caminhar em um mundo que não é estruturado nem pela autoridade nem tampouco mantido coeso pela tradição [p. 245]. 
Quando esse sentido de autoridade não é reconhecido o professor tem dificuldade para conduzir o processo educativo, o que pode incorrer na perda de qualquer tipo de influência sobre o outro ou no uso da violência e do poder para restaurar sua autoridade. No caso do uso da violência seria impossível se restabelecer qualquer tipo de autoridade, pois, como já foi dito, estaria caracterizado o autoritarismo. No caso do uso do poder, também, pois para Arendt "a característica mais proeminente dos que detêm autoridade é não possuir poder" (p. 164), ou seja, a autoridade não se impõe, mas se reconhece.

O processo de crise da autoridade tem conexões com a crise da tradição, com a crise da educação e com a perda progressiva de nossa capacidade de intercambiar experiências, o que, sem dúvida, serve de combustível para as críticas à educação tradicional através das quais o professor foi, aos poucos, perdendo sua legitimidade como educador. Quando o aluno passa a ser visto como o protagonista de seu processo de formação, o professor perde sua autoridade sobre o assunto e sobre 0 ensino, tornando-se o organizador de atividades para a aprendizagem. $O$ educador alemão Hellmut Becker, em diálogo com Theodor Adorno, afirma que "o processo de rompimento com a autoridade é necessário, porém que a descoberta da identidade, por sua vez, não é possível sem o encontro com a autoridade" (BECKER apud ADORNO, 1995, p. 177).

A crise de autoridade do professor se manifesta na procura por outras formas de identificação vindas de contextos de ação sociocultural pelos educadores em arte. Como já foi dito, o problema não está na variedade de designações, mas na multiplicidade de funções que o arte educador assume ou acha que deva assumir quando exerce sua docência no contexto escolar. Entender qual seria o papel do Professor de Arte e do Professor de Teatro na Educação Básica passa pela necessidade de se entender o contexto escolar e o sentido da escola, pois, ao que parece, muito dessa multiplicidade se deve à falta de clareza sobre esse sentido em nossa sociedade. 


\subsection{0 aluno: entre o saber escolar e o saber da arte}

Se a arte e a escola operam de maneiras diferentes (sobre) o conhecimento, como problematizado anteriormente, também ocupam diferentes esferas da vida humana. Em sendo assim, inserir a arte no currículo escolar suscita uma série de questões. No caso da Educação Básica brasileira, qual seria a finalidade da arte escolarizada? Pretende-se que o aluno aprenda arte ou que aprenda as linguagens artísticas? Isto é, que o aluno aprenda o ofício do artista e, por conseguinte, suas técnicas ou que a arte faça parte de sua formação como cidadão crítico? Isabel Marques e Fábio Brazil colocam esta questão a partir de uma perspectiva cidadã, pois, para eles, "professor é cidadão, aluno é cidadão, gestor é cidadão, artista é cidadão, pesquisador é cidadão" (MARQUES e BRAZIL, 2014, p. 13), mas também defendem a necessidade de ensino do ofício, do fazer, dentro da escola: "Por que não devemos pensar desde cedo naqueles que se tornarão artistas?" (p. 67). "O artista não será um cidadão? Estará além ou aquém disso? O cidadão não precisa conhecer arte?" (p. 72). Ou seja, partem do princípio de que essas aprendizagens estão conectadas e o aprendizado da linguagem passa necessariamente pelo aprendizado técnico, e vice-versa, pois, para eles, "há pelo menos duas décadas, [...] o ensino de Arte tem sido intimamente ligado ao universo dos artistas 'fazedores' de arte em contexto sociocultural" (p. 58). Desta maneira, "criar/produzir trabalhos de arte é o papel dos artistas em sociedade, portanto, nada mais significativo do que trabalhar a arte nas escolas relacionadas ao ato de criar/produzir e experimentar com as diversas linguagens" (p. 59).

Marques e Brazil parecem propor a transferência direta das formas de produção de arte e dos modos pedagógicos próprios a contextos socioculturais para o âmbito escolar. Mas em se tratando de contextos diferentes (escola formal, ação sociocultural e mesmo escolas de ofício) isto não implicaria em modos pedagógicos diferenciados? Não seria necessário pensar formas de transposição didática dos conhecimentos produzidos pela arte para o âmbito escolar?

De acordo com a legislação educacional brasileira, a inserção da Arte na Educação Básica é vista de maneira diferenciada em cada nível de ensino. Segundo 
os Parâmetros Curriculares Nacionais (PCN), no Ensino Fundamental I entende-se que "a educação em arte propicia o desenvolvimento do pensamento artístico, que caracteriza um modo particular de dar sentido às experiências das pessoas" (BRASIL, 1997b, p. 15); no Ensino Fundamental II, em que as aulas são ministradas (idealmente) por professores especialistas em cada uma das quatro linguagens artísticas (Teatro, Dança, Artes Visuais e Música), “a Arte passa a vigorar como área de conhecimento e trabalho com as várias linguagens e visa à formação artística e estética dos alunos" (BRASIL, 1998, p. 19):

A manifestação artística tem em comum com outras áreas de conhecimento um caráter de busca de sentido, criação e inovação. Essencialmente, o ato criador, em qualquer das formas de conhecimento humano, ou em suas conexões, o homem estrutura e organiza o mundo, respondendo aos desafios que dele emanam, em um constante processo de transformação de si e da realidade circundante [p. 30].

E, por fim, no Ensino Médio, Arte, "considerada particularmente pelos aspectos estéticos e comunicacionais" (BRASIL, 2000b, p. 48), integra a área Linguagens, Códigos e suas Tecnologias, junto com Português, Educação Física e Língua Estrangeira Moderna. O sentido do aprendizado dessa área é a utilização "das linguagens como meio de expressão, informação e comunicação em situações intersubjetivas, que exijam graus de distanciamento e reflexão sobre os contextos e estatutos de interlocutores; e saber colocar-se como protagonista no processo de produção/recepção" (p. 10).

Pode-se entender que o estudo da Arte vai se tornando mais complexo a cada nível de ensino da Educação Básica, iniciando-se como uma maneira de pensar e "dar sentido às experiências" pessoais, passando por sua legitimação como área de conhecimento, com "um caráter de busca de sentido, criação e inovação", para concluir-se como linguagem, ou seja, "meio de expressão, informação e comunicação" entre as pessoas e com o mundo. Eis a definição de linguagem presente nos PCN-Arte, já apresentada anteriormente:

capacidade humana de articular significados coletivos em sistemas arbitrários de representação, que são compartilhados e que variam de acordo com as necessidades e experiências da vida em sociedade. A principal razão de qualquer ato de linguagem é a produção de sentido [p. 19]. 
Tomando-se por base essas diretrizes para a educação escolar no Brasil, o que se pretende, portanto, com o ensino curricularizado da arte é capacitar os jovens em diversas linguagens de maneira que as expressões artísticas sejam carregadas de sentidos que possam ser compartilhados. Ou seja, deseja-se que, ao final da Educação Básica, o aluno compreenda as linguagens das artes em seus aspectos estéticos e comunicacionais, sendo que os PCN-Arte entendem a palavra estética, derivada do grego, como "sentir" (p. 48). Assim, a formação em Arte do aluno deve privilegiar tanto a leitura em um sentido ampliado do ato de ler, como tudo o que pode ser sentido fisicamente, o que "entra" pelos olhos, boca, nariz, ouvidos e pele, quanto o ato de comunicação, que envolve a própria leitura, e, por conseguinte, o produtor - aquele que faz algo e o torna público, portanto, o artista - e o objeto da comunicação - o produto (ou processo) artístico em si. Para que o processo comunicacional aconteça é necessário que haja um "sistema arbitrário de representação" compartilhado, isto é, não basta saber fazer, é preciso dominar os códigos da linguagem e saber lê-los, articulando significados coletivos e, assim, criando sentidos. Se os aspectos estéticos e comunicacionais devem ser privilegiados pode-se apreender que os aspectos técnicos e poéticos estão "a serviço" dos primeiros. Parece-nos que na Educação Básica brasileira o ensino da Arte deve se voltar, prioritariamente, para a formação do cidadão e não a do artista. De qualquer forma, essa afirmação não se configura como uma resposta para a questão levantada, pois é preciso observar ainda se o aprendizado das linguagens artísticas passa necessariamente pelo domínio do ofício.

Como modo pedagógico, os PCN-Arte indicam a abordagem triangular proposta por Ana Mae Barbosa, no qual os processos educativos em Arte devem contemplar ações em três eixos de experiência: no fazer (no qual se insere a técnica e a poética), no fruir (onde se trabalharia o ato da leitura, do acontecimento estético) e no contextualizar (em que o conhecimento da arte se articula com os conhecimentos do mundo). Nestes três eixos seria possível delimitar onde estaria o aprendizado do ofício e onde estaria o da linguagem? Somente em um ou, necessariamente, em todos? É impossível uma resposta, pois o aprendizado por si só é individualizado, não se podendo precisar como cada indivíduo aprende e apreende as coisas do mundo e sua relação com elas. Mas pode-se pensar na 
preponderância de uma ação sobre as outras, o que poderia diferenciar e determinar as especificidades entre a formação voltada à cidadania da formação voltada para um ofício artístico.

Ainda que os PCN-Arte não sejam suficientemente claros a esse respeito, entendemos que a arte como matéria de estudo e prática dentro da escola é necessária para a formação do cidadão, mas que seu ensino deve operar o mais próximo possível dos modos pedagógicos escolares. A necessidade de se submeter a esses modos visa preservar o sentido da escola como um "tempo livre" em que um novo mundo é gestado cotidianamente e como suspensão das esferas privada e pública da vida humana. Submeter a arte às formas de operar sobre o conhecimento próprias da escola é entender que a formação do cidadão em arte deve ocorrer de maneira diferenciada do aprendizado dos ofícios artísticos. Em sendo assim, a escola não deveria ser o local para o aprendizado do ofício do artista, da técnica, pois não se configura como um lugar para a criação. Não se quer, com essa afirmação, colocar a criação artística para fora da escola, mas relativizá-la como parte do processo de aprendizado da linguagem. A produção de arte dos alunos deve fazer parte do processo de sua formação estética, mas não se configurar como projeto de Arte na escola.

O ensino das linguagens artísticas dentro da escola precisa ser um ato de abrir o mundo das artes para compartilhá-lo como bem comum entre as velhas e as novas gerações, sem a preocupação em tornar o tempo livre escolar um tempo produtivo voltado para a preparação para o futuro no qual os alunos seriam iniciados em um ofício.

A questão que Masschelein e Simons propõem é como os jovens

podem renovar o mundo - como eles podem experimentar a "inovação" - se ninguém realmente os apresenta ao velho mundo e traz o mundo antigo para a vida? [...] Isso é, precisamente, o que Hannah Arendt $^{22}$ insiste que os professores se lembrem de quando ela, eloquente e acertadamente, diz que o professor age por amor ao mundo ("isto é importante para nós, a velha geração") e por amor às crianças ("cabe a você, a nova geração, moldar o novo mundo"). Isso é o que constitui a responsabilidade pedagógica do professor. Tem, portanto, mais a ver com amor do que com ser capaz

${ }^{22}$ Citação do texto A crise na Educação, in ARENDT, 2011. 
de fornecer explicações ou justificações - que é o que, atualmente, é esperado dos professores [MASSCHELEIN e SIMONS, 2013, p. 102, grifo dos autores].

Desta maneira, se a escola se propõe a ensinar as linguagens artísticas, não é possível se ater somente à criação ou à contextualização, que predominam nas aulas de Arte atualmente. Isabel Marques e Fábio Brazil fazem uma distinção entre o que é repertório, "'coisas prontas' que devemos aprender a fazer/copiar ou saber informações sobre elas" (MARQUES e BRAZIL, 2014, p. 128), do que é linguagem. Para eles, é preciso entender a "arte como uma forma de articulação de linguagem, como linguagem viva, como linguagem dos vivos" (p. 128). Para eles, os repertórios em arte devem ser vistos como "sistemas de signos articulados para a produção de múltiplos sentidos, são articulações de estruturas das linguagens" (p. 130), próprios a operações de leitura. "Os diferentes repertórios de arte (coreografias, peças, pinturas, esculturas, partituras etc.) são como 'livros': essenciais para a fruição, para o aprendizado, para a produção pessoal e/ou coletiva de novos textos" (p. 130).

A linguagem, por sua vez, "não apenas 'nomeia', mas, sobretudo, age sobre a realidade, cria realidades, é uma ação" (p. 137). Desta maneira, o aprendizado das linguagens artísticas estaria para além da leitura de repertórios (cujo sentido se assemelha a patrimônio da humanidade, tantas vezes usado neste trabalho), pois permitiria aos alunos "a produção de novos trabalhos de arte" (p. 137), abrindo a possibilidade para o aparecimento do novo.

$\mathrm{O}$ que se questiona nesta perspectiva é se o aprendizado das linguagens artísticas na escola deve ter como objetivo a produção do novo, a preparação e a capacitação para que este novo seja criado já dentro da escola, o que significaria operar sobre o repertório (habilidades e conhecimentos) como ferramenta. Para Adorno, "é preciso romper com a educação enquanto mera apropriação de instrumental técnico e receituário para a eficiência, insistindo no aprendizado aberto à elaboração da história e ao contato com o outro não-idêntico, o diferenciado" (ADORNO, 2012, p. 27). O contato com o outro só pode se dar quando eu olho, ouço, cheiro e sinto o outro; quando deixo por um momento de falar para escutar, de escrever para ler, de fazer para fruir, de consumir para apreciar. 
A aprendizagem das linguagens artísticas deve operar sobre os três eixos propostos pela abordagem triangular (fazer, fruir e contextualizar), porém, em nosso entendimento, se se deseja uma escola como "tempo livre", em suspensão, alienada de um mundo voltado à produção, que vê as coisas desse mundo de uma maneira profana como objeto de estudo sem finalidade imediata, a leitura, a escuta, a atenção à matéria, a educação estética deve ser sua ação pedagógica fundamental. Para Masschelein e Simons,

não se trata de um recurso, produto ou objeto para utilização como parte de uma determinada economia. Trata-se de um momento mágico quando alguma coisa fora de nós mesmos nos faz pensar, nos convida a pensar ou nos faz coçar a cabeça. Nesse momento mágico, algo de repente deixa de ser uma ferramenta ou um recurso e se torna uma coisa real, uma coisa que nos faz pensar, mas também nos faz estudar e praticar [MASSCHELEIN e SIMONS, 2013, p. 51].

Assim, fazer e contextualizar devem estar a serviço da leitura da arte, ou seja, do estudar e pensar arte no mundo e como parte do mundo. Ato de leitura que é fruto de um trabalho de formação que visa a abertura do aluno para o mundo das linguagens artísticas, colocando a sua própria identidade em crise (p. 49). Para Adorno, segundo Maar, a experiência formativa com sentido emancipatório necessita da "disponibilidade para o contato com o objeto, como abertura ao empirismo. [...] O pensamento precisa recuperar a experiência do concreto sensível ('ouvir uma sonata de Beethoven da sala ao lado...')" (MAAR, 1995, p. 24).

Abertura que implica aprender (com) outras formas de lidar com a linguagem e na negação de pedagogias que privilegiam modos de aprendizagem autorreferenciais a partir somente de experiências do fazer. Se a abordagem triangular for trabalhada somente com a finalidade da produção, baseada principalmente na expressão do aluno, concorrerá para tornar a educação escolar da Arte cada vez mais uma aprendizagem individual e individualizante, da qual deriva, em muitos casos, uma leitura simplista baseada em juízos de gosto e uma contextualização reduzida. Sem o compromisso com o ensino, a linguagem artística corre o risco de se esvair, de se diluir em diversas linguagens individuais desconexas e incompreensíveis, incapazes de criar sentidos. 
Como afirmam Masscheleine e Simons, "o aluno não quer alguém que está interessado nele/nela, mas sim alguém que está interessado em outras coisas e assim pode gerar interesse nessas coisas" (MASSCHELEINE e SIMONS, 2013, p. 78). Quando a escola privilegia o aprendizado da Arte a partir das formas de operar próprias da criação artística, ou seja, do fazer, nas quais o aluno é o único protagonista de sua formação, ela se abstém de colocar em cena o outro protagonista necessário à educação escolar, o mundo. "A educação é a concessão de autoridade para o mundo, não só por falar sobre o mundo, mas também e sobretudo por dialogar (encontrar, comprometer-se) com ele. Em suma, a tarefa da educação é garantir que o mundo fale com os jovens" (p. 98). Quando a escola deixa de ensinar a linguagem artística como criação da humanidade, como códigos sob os quais repousa a comunicação do artista com o mundo, ela acaba por se fixar na crença em uma semiformação que é alienada e alienante do próprio mundo. 
3

\section{RECEPÇÃO, CRIAÇÃO E APRENDIZAGEM:}

A LINGUAGEM TEATRAL NA EDUCAÇÃO BÁSICA

Teatro é um tablado, dois atores e uma paixão! Lope de Vega 
Uma das características da arte é sua imprecisão conceitual, podendo ser identificada e classificada de diversas maneiras. Jorge Coli afirma que "para decidir o que é ou não arte, nossa cultura possui instrumentos específicos. Um deles, essencial, é o discurso sobre o objeto artístico, ao qual reconhecemos competência e autoridade" (COLI, 1995, p. 10). Três desses discursos foram identificados e classificados em regimes de identificação das imagens, por Jacques Rancière (2009), como foi visto no capítulo anterior.

A diversidade de discursos para a identificação do que seria arte também ocorre para a identificação das linguagens artísticas, na qual estabelecem-se normas ou sistemas que verificam as maneiras de se operar no caos ou a natureza dos suportes e dos materiais utilizados ou ainda as diferentes exteriorizações que a manifestação artística pode assumir. O regime poético ou representativo aristotélico gerou a clássica divisão da arte em seis linguagens de acordo com a natureza de sua produção ou maneira de operar no caos, que seriam a arte do som (música), do movimento (artes cênicas: teatro e dança), da cor (pintura), do espaço (arquitetura), do volume (escultura) e da palavra (literatura), às quais foram sendo acrescidas as artes dos séculos XIX e XX, como a da imagem fixa (fotografia) e das imagens em movimento (cinema e artes digitais).

A partir do regime estético, o filósofo alemão G. W. F. Hegel formulou seu Sistema das Artes inspirado na Educação Estética do Homem, de Schiller (1995). Inicialmente, Hegel eliminou três dos cinco sentidos humanos em sua classificação da recepção, o tato, o olfato e o paladar, pois, segundo ele, somente a visão e a audição se colocariam em uma relação teórica, isto é, distanciada e não material com a obra de arte. Ambas, aliadas a um terceiro elemento, "a representação sensível, a lembrança, a persistência das imagens que cada contemplação faz entrar na consciência" (HEGEL, 2010, p. 14), compõem o triplo modo de concepção que divide a arte "em artes plásticas, que elaboram o seu conteúdo ao dar-Ihe uma forma e uma cor objetivas, e em artes rítmicas, a música e também a poesia..." (p. 15). Tal divisão revelaria a impossibilidade de que a arte reflita a plenitude da realidade, como também pensava o escritor e crítico literário russo Andréi Biely, em fins do 
século XIX, que afirmava que "a arte liga-se ora à ideia ora à mudança das ideias: no primeiro caso surgem as formas estéticas espacializadas, no segundo, as formas temporais" (BIELY apud MEIERHOLD, 2009, p. 343).

Observe-se que esta classificação baseia-se na supremacia da razão sobre os sentimentos, pois a forma está submetida ou é consequência de uma ideia anterior à sua execução. Talvez esse tenha sido um dos motivos para que Hegel recusa-se essa divisão alegando que ela não é "extraída do conceito concreto da própria coisa" (HEGEL, 2010, p. 15) e sugerisse que as diferenças entre as artes concernem tanto à concepção como à execução, isto é, nas relações entre conteúdo e forma. A partir deste entendimento, Hegel propõe uma nova divisão da arte em simbólicas, clássicas e românticas. A arte simbólica seria aquela em que não há identidade entre forma e conteúdo, mas somente uma afinidade, uma simples alusão, cabendo à arquitetura o primeiro lugar no sistema hegeliano. O segundo lugar seria da escultura, que corresponderia ao ideal clássico de representar "o absoluto como tal na sua independente realidade" (p. 16), pois a interioridade e a espiritualidade encontram "sua expressão no aspecto corporal imanente ao espírito" (p. 17). Por fim, a arte romântica que, para Hegel, "exprime a subjetividade do espírito na sua infinitude, ao mesmo tempo que na sua particularidade finita" (p. 16), exteriorizando a interioridade subjetiva. As artes românticas seriam a pintura, que suprime a realidade sensível, espacial, tridimensional, e a transforma em aparência através da cor, no polo oposto, a música, que é pura interioridade, "o sentimento desprovido de forma" (p. 18), que se manifesta através dos sons; e, por fim, a poesia, a arte da palavra, "a verdadeira arte absoluta do espírito manifestando-se como espírito" (p. 18), pois só a palavra é capaz de se apropriar de tudo quanto a consciência concebe e transformar em objeto de representação.

No Sistema das Artes hegeliano o teatro é visto como poesia, arte da palavra conforme a tradição aristotélica. Na Poética, Aristóteles denomina o modo que se utilizam "pessoas imitadas, operando e agindo elas mesmas" (ARISTÓTELES, 1987, pp. 202-3), de drama, "pelo fato de se imitarem agentes [dróntas]" (p. 233). Para Hegel, a arte dramática expressa "por palavras uma ação determinada que, embora prestando-se sob um aspecto objetivo, exprime a interioridade desta realidade objetiva e pode, por esta razão, ser associada à música, para permitir a mímica, os 
gestos, a dança etc." (HEGEL, 2010, p. 19). Interessante que Hegel afirma existirem outras artes além das cinco pertencentes ao seu Sistema, "tais como a dança, a arte dos jardins etc." (p. 20), mas que estas seriam "artes incompletas".

Se as maneiras de classificação da arte e sua divisão em linguagens possuem diferentes pontos de vista, o que torna arbitrária qualquer classificação, o fato é que as linguagens artísticas se diferenciam entre si e essas diferenciações também estão presentes em seus modos pedagógicos. O teatro, a música e a dança, segundo Jorge Coli, por não se apoiar em suportes materiais,

\begin{abstract}
devem sua sobrevivência a uma cadeia de aprendizado, a uma corrente de tradições recolhidas por uma instituição muito justamente chamada conservatório. [...] Essa cadeia transmite o saber de outros tempos mas, ao mesmo tempo que o passa para frente conservando assim seus elementos -, ela os modifica. [...] Mais radical ainda, o caso do teatro. O texto é uma base sólida, mas tudo o que constitui o espetáculo depende de indicações muito menos precisas, que se apoiam apenas num saber por assim dizer "intuitivo" - saber que se transmite, mas é profundamente sensível às alterações [COLI, 1995, p. 78].
\end{abstract}

A transposição didática das linguagens artísticas para a sala de aula da Educação Básica deve levar em consideração essas diferenças estéticas, poéticas e pedagógicas, pois é de se supor que o estudo e a prática de uma arte que se exprime através de sons possua modos de aprendizagem diferentes em relação a outra que se exprime através da volumetria. Dessa maneira, se justificaria a divisão indicada nos PCN-Arte para a área em componentes curriculares distintos, no caso, a Dança, o Teatro, a Música e as Artes Visuais, que deveriam ser estudados, cada um, ao longo de um ano letivo diferente, pois é preciso oferecer um "tempo livre", não produtivo, para que se compreendam as qualidades estéticas do som, por exemplo. Assim, se no capítulo anterior tratou-se a arte de maneira genérica como área de conhecimento, não se levando em conta as diferenciações entre as linguagens artísticas, aqui se irá distinguir as especificidades da linguagem teatral e seus modos pedagógicos na tentativa de enfrentar os dilemas apresentados no início deste trabalho entre a realidade da Educação Básica alagoana e brasileira e os PCN-Arte. 


\subsection{A linguagem do teatro}

Tomando-se por base as classificações apresentadas acima, pode-se dizer que hoje a linguagem teatral é considerada como aquela que envolve em sua composição o movimento e a plástica, o tempo e o espaço, o volume, o som, a palavra, a cor e a imagem, inclusive a digital. Para o encenador Gordon Craig,

a arte do teatro não é nem a arte da interpretação do ator, nem a peça de teatro, nem a figuração cênica, nem a dança. [...] É o conjunto de elementos dos quais se compõem esses diferentes domínios. Ela é feita de movimento, que é o espírito da arte do ator, de falas, que formam o corpo da peça, de linha e de cor, que são a alma do cenário, de ritmo, que é a essência da dança [CRIAG apud PAVIS, 1999, p. 26].

Não se quer, com isto, defender que o ensino da linguagem teatral na Educação Básica deva abarcar, indistintamente, todas as artes em uma espécie de transposição didática da ideia de Gesamtkunstwerk formulada por Richard Wagner $^{23}$, mas indicar que essa diversidade de linguagens deve, necessariamente, ser levada em consideração na sala de aula.

Talvez seja necessário, contudo, estabelecer uma espécie de essencialidade da linguagem teatral através daqueles elementos sem os quais o teatro não se realiza e que comporiam a tríade aludida por Lope de Vega: o tablado, os atores e a paixão. Em termos gerais, o tablado é o palco, o espaço cênico e plástico, o local onde a apresentação de uma "paixão" acontece, o que pressupõe que haja outro espaço no qual se assista, o local "de onde se vê", o espaço do espectador. Uma apresentação pressupõe a presença humana de um apresentador, mesmo que esta seja através da manipulação e animação de objetos cênicos, ou até mesmo fora da cena, o que faz do teatro também uma arte do tempo, do movimento e efêmera, puro acontecimento, irreproduzível por meios mecânicos ou digitais em sua totalidade. E, por fim, a paixão é a ação apresentada ou, dito de outra forma, é o que se

${ }^{23}$ Gesamtkunstwerk, do alemão, segundo a definição de Patrice Pavis (1999): "Termo forjado por Richard Wagner, por volta de 1850. Literalmente, obra de arte global (ou de conjunto ou total) às vezes traduzida (meio às pressas) por teatro total. A estética da ópera wagneriana procura a obra 'mais altamente comunitária' que seja uma síntese da música, da literatura, da pintura, da escultura, da arquitetura, da plástica cênica etc." (p. 183). 
depreende da apresentação de uma ação. Atualmente, a noção de espaço dividido entre a cena e o espectador deixou de ser norma e parte da natureza do teatro, podendo-se sobrepor e ocupar o mesmo espaço de jogo, bem como a ação pode não ser a (re)apresentação de um mito, de uma fábula, mas sua narração ou até mesmo a presentificação da ação em si, decorrente da influência da arte da performance no teatro. Mesmo a ação, representada ou não, já não é exclusividade dos atores, pois muitas vezes o público é convidado a atuar. Mas, em essência, no teatro sempre há um ser humano que apresenta algo para que outro ser humano assista, constituindo os elementos necessários para que o fenômeno teatral se realize, segundo a tríade de Lope de Veja, que também poderiam ser chamados, em outra perspectiva, de ator, texto e espectador. Cabe ainda a ressalva que, para nós, nesta perspectiva, "texto" não é necessariamente uma base literária, mas remete a ideia de tessitura, "da disposição das partes no roteiro a ser seguido, a fixação de traços e esboços ou figuras de personagens e a ordenação dos elementos verbais, dialógicos e ambientais" (GUINSBURG, 2001, p. 9).

Para efeitos dessa pesquisa cabe acrescentar a essa tríade essencial de Lope de Vega na qual se constitui a linguagem teatral uma tríade pertencente ao campo da pedagogia da arte - recepção-criação-aprendizagem -, que remete à estética, à poética e à técnica. Essa tríade pedagógica pode ser analisada a partir de diferentes perspectivas que se refletem em sua ordenação e na ênfase dada a cada uma delas para a formação do sujeito.

Comecemos por Aristóteles. O entendimento da poesia e, por conseguinte, da poesia dramática, como imitação (mímeses) das ações humanas, presente na Poética aristotélica, aproxima a arte do teatro à formação ética do indivíduo, pois a ação de representar é vista aqui como um instrumento pedagógico. Perspectiva presente no pensamento ocidental (eurocêntrico) até nossos dias. Para Aristóteles, a imitação estaria na origem da poesia, porque "o imitar é congênito no homem (e nisso difere dos outros viventes, pois, de todos eles, é ele o mais imitador, e, por imitação, aprende as primeiras noções), e os homens se comprazem no imitado" (ARISTÓTELES, 1987, p. 203). O aprendizado através da arte e do teatro estaria, assim, tanto na ação de imitar, realizada pelo poeta e pelo ator, como na apreciação dessa imitação, pois os homens 
se deleitam perante as imagens: olhando-as, aprendem e discorrem sobre o que seja cada uma delas, [e dirão], por exemplo, "este é tal". Porque, se sucede que alguém não tenha visto o original, nenhum prazer lhe advirá da imagem, como imitada, mas tão-somente da execução, da cor ou qualquer outra causa da mesma espécie [p. 203].

Denis Guénoun observa que Aristóteles instaura uma diferença entre as duas aprendizagens, a da ação e a da observação, pois esta que se dá pelo olhar proporcionaria prazer: "A representação permite a quem olha concluir a respeito do ser daquilo que ele vê. Ela dá acesso ao ser do que é visto, e não apenas à aparência enganosa. A mímesis informa a respeito da essência. Sua visada, cognitiva, causa prazer" (GUÉNOUN, 2004, p. 27). O prazer em aprender através das imagens, em assistir a imitação das ações humanas realizada por atores, é o prazer que se tem com o próprio aprendizado na aquisição de um conhecimento que não se possuía. "Poderíamos dizer então que o que distingue esta aprendizagem (visual) da outra (prática) é o prazer de aprender. E este prazer é um prazer de conhecer. Um prazer de acesso ao ser do que é visto. Ou: um prazer de aprendizagem teórica (segundo Althusser)" (p. 32).

O prazer deve, portanto, ser aqui claramente compreendido como prazer teórico, prazer da formação, da gênese (atividade sui generis) de um conhecimento não anteriormente constituído. Este conhecimento procede pelo desprendimento de uma forma. Isso porque ela é irredutível à visão simples: a visão apreende o conjunto constituído pela forma e por sua matéria, a forma não pode ser ali imediatamente isolada. Cabe ao conhecimento extraí-la. O prazer do conhecimento é o prazer dessa abstração. [...] O prazer teórico assim ativo no olhar sobre a representação é o prazer da descoberta, isto é, um prazer ligado à produção da novidade, que se determina então como gênese do conhecimento da forma. Conhecimento que a coisa não dá quando ela própria se apresenta, e que reside na revelação, na abstração de uma morphé [p. 32, grifos do autor].

Richard Courtney (2003), em sua obra Jogo, Teatro e Pensamento, faz um panorama histórico das relações entre teatro e educação e das polarizações entre a aprendizagem visual (teórica) e a prática teatral. Seu ponto inicial é a rejeição platônica às artes e ao teatro, pois, para Platão, "o ideal é a verdade, e a realidade é uma cópia (imitação) dela. O teatro está ainda mais longe da verdade, porque imita a realidade" (COURTNEY, 2003, p. 6). Em sua análise, Courtney associa o sentido da arte teatral ao de jogo como improvisação dramática e, assim, discorre sobre o pensamento de diversos autores que, ora defendem um propósito educacional para 
o teatro, como Horácio, ora o rejeitam, influenciados pelo platonismo, como Sêneca, que "condenou o palco porque este desviava o povo da séria ocupação de aprender e escreveu seus próprios dramas não para o teatro mas para o estudo" (p. 8), fazendo uma clara distinção entre o espetáculo teatral e a literatura dramática. A condenação moral do fazer teatral influenciará autores como Erasmo e Lutero e o pensamento católico até o século XII, quando a filosofia aristotélica reaparecerá dentro das escolas e dos monastérios. São Tomás de Aquino irá adaptar essa filosofia à fé católica, "dando plena aprovação à representação, desde que fosse recreação" (p. 9), o que impulsionará sobremaneira a criação de "um teatro litúrgico com um propósito didático centrado nas escolas monásticas [com o objetivo de] ajudar o analfabeto a compreender a fé" (p. 9).

Na defesa da ação pedagógica do teatro há uma interessante variação entre autores que veem toda e qualquer manifestação dramática como útil à educação e aqueles que distinguem o teatro didático e recreativo do teatro profissional, como São Tomás de Aquino. No que tange à atuação, Francis Bacon enaltece aquela voltada aos objetivos educativos ao mesmo tempo em que condena o ofício:

De fato, trata-se de algo de baixa reputação, se praticado profissionalmente; mas, se for feito parte de disciplina, então, será de excelente uso. Refiro-me a atuar no palco; uma arte que fortalece a memória, regula o tom e efeito da voz e pronúncia, ensina um comportamento decente para a fisionomia e gestuação, promove a autoconfiança e habitua os jovens a não se sentirem incômodos quando estiverem sendo observados [BACON apud COURTNEY, 2003, p. 12].

Göethe é outro autor que defendia a educação dramática mas não via no teatro profissional o mesmo sentido educativo. A partir da leitura da obra de Philip Coggin, Courtney afirma que para Göethe o teatro escolar "tem um efeito benéfico tanto sobre o espectador como sobre o ator: exige grandes habilidades de memória, gesto e disciplina interna" (COURTNEY, 2003, p. 16). A desconfiança em relação aos efeitos educativos do teatro como ofício está presente até mesmo em Rousseau, grande defensor de uma educação lúdica, para quem "o teatro profissional apenas justifica-se quando é útil" (p. 18).

Observam-se nos exemplos acima diversas polarizações nas relações entre teatro e educação, desde o questionamento de seu caráter educativo, passando 
pela distinção entre aquele que atua daquele que assiste, entre o espetáculo teatral e a literatura dramática, entre o aprendizado realizado por meio da ação de imitar (a produção poética) daquele voltado ao caráter técnico da atuação (valorização da memória, articulação vocal, desenvoltura corporal etc.), entre o aprendizado sobre algo (a fé cristã, por exemplo) da aprendizagem sobre si mesmo (a autoconfiança), entre o ofício e a atuação escolar, entre o espetáculo profissional e as montagens com cunho didático. Polarizações que se colocam sob a perspectiva do teatro como representação; na ideia de que alguém que representa sempre o faz para outro alguém. Denis Guénoun afirma que

as representações respondem a uma necessidade, na medida em que sua ocorrência está inscrita na natureza dos homens. Mas esta necessidade, de saída, se divide: em uma tendência a produzir representações e uma tendência a se comprazer com isto. (...) Esta dualidade recorta, no geral, nossa distinção entre 'fazer teatro' e 'ir ao teatro', entre o teatro que se pratica e aquele que se vê [GUÉNOUN, 2004, p. 19].

Tal distinção entre estética e poética deveria problematizar o ensino da linguagem teatral na Educação Básica, mas não só ela. Maria Lucia Pupo, por exemplo, ressalta que ao longo desse percurso histórico deve-se ter em conta que diversas foram as concepções acerca do teatro e da educação:

Diferentes visões do papel de educação foram sustentadas ao longo dos séculos, até chegarmos a esse início de milênio. Do mesmo modo o fenômeno teatral veio se transformando sem cessar. Diferentes têm sido os modos de fazer e pensar a representação, assim como funções diversificadas vem sendo atribuídas à cena, desde o tempo de seu surgimento em terras gregas até nossos dias [PUPO, 2001, p. 31].

Donde conclui que "pensamos o que pensamos sobre essa aliança [entre teatro e educação] porque a pensamos hoje, porque atualmente 0 teatro e a educação apresentam determinados contornos que não poderiam apresentar, por exemplo, nos anos cinquenta" (p. 31). Nesta perspectiva histórica que olha para trás com os pés no hoje, podem-se detectar algumas possíveis heranças nas relações entre teatro e educação, algumas práticas e tendências da pedagogia do teatro hoje em voga, evidenciadas por uma tensão na ênfase dada ora à recepção, ora à atuação, e agrupá-las em três grandes tendências para efeito de análise dentro do contexto escolar. 


\subsubsection{Pedagogias ${ }^{24}$ do espetáculo}

Uma das tendências observadas nos exemplos acima é atribuir à recepção o efeito educativo do teatro, ou seja, a intenção pedagógica do ato teatral está voltada aos espectadores. É no theatron, "o lugar de onde se vê o espetáculo" (PAVIS, 1999) - palavra grega que designa o lugar do espectador -, em que ocorreria a aprendizagem do indivíduo. Aprendizagem que visa à formação do cidadão, em uma perspectiva que se identifica ao regime ético das imagens (RANCIÈRE, 2010), cujos conteúdos são o mundo e não propriamente a linguagem teatral. Porém se o teatro é o meio, a mídia, a "língua" com a qual se realiza a comunicação estética, assim quanto maior for o domínio da linguagem, quanto melhor for realizado o ato de leitura das formas apresentadas, maior será a fruição e o aprendizado. Neste sentido, Aristóteles afirma que o prazer não vem do objeto imitado, do conteúdo, mas da "execução, da cor ou qualquer causa da mesma espécie" (ARISTÓTELES, 1987, p. 203). Essa ideia de prazer perpassa as pedagogias da recepção do espetáculo, pois, como escreveu o poeta e filósofo romano Horácio, "todo louvor obtém aquele poeta que une informação com prazer, ao mesmo tempo iluminando e instruindo o leitor" (HORÁCIO apud COURTNEY, 2003, p. 8).

Nesta perspectiva educativa que privilegia a recepção, a criação ocupa um papel secundário como operador da aprendizagem. $O$ aprendizado daquele que realiza a ação dramática, o ator, e daqueles que possibilitam essa realização, o dramaturgo e o encenador, é de ordem diversa da experienciada pelo espectador, pois está ligada a poéticas e técnicas específicas a cada ofício. Outros profissionais atuam para a realização do acontecimento teatral - como pintores, arquitetos, iluminadores, músicos e dançarinos - porém suas formações artísticas são específicas de seus ofícios, ainda que transpostas para a cena teatral. Se a

\footnotetext{
${ }^{24}$ Optou-se pelo termo pedagogias, no plural, no lugar de metodologias ou abordagens termos que talvez se adequassem melhor à área da Pedagogia do Teatro -, como forma de estabelecer um diálogo com as formulações do capítulo anterior, no qual diversas metodologias de ensino e aprendizagem foram chamadas de pedagogias. A parte essas nomenclaturas, no corpo do texto ora se falará em metodologia, ora em abordagem, de acordo com o sentido que se considere mais apropriado.
} 
essência do teatro constitui-se na tríade ator-texto-espectador, e se relacionarmos a função do encenador a de um espectador interno com o poder de selecionar "o que se dará a ver"25, poderíamos propor uma tríade relacionada ao fazer teatral constituída pelo ator, pelo dramaturgo e pelo encenador. Três modos de fazer, três formações técnicas distintas, ainda que, em geral, guiadas por uma mesma poética, que se comunicam esteticamente com o espectador por meio da linguagem teatral com o intuito de produzir sentidos.

Podem-se chamar de "pedagogias do espetáculo" aquelas modalidades pedagógicas que operam os processos de ensino e aprendizagem da linguagem teatral a partir da noção de espetacularidade. O espetáculo, para Aristóteles, é uma das seis partes constituintes da tragédia ao lado do mito, do caráter, da elocução, do pensamento e da melopeia, e, ainda que a mais emocionante, é a menos artística, pois a menos própria à poesia (ARISTÓTELES, 1987, p. 207). A concepção literária de Aristóteles aliada à condenação moral platônica talvez possa explicar a rejeição que cercou (e, em muitos casos, ainda cerca) o espetáculo teatral como meio educativo, o que pode ser observado na predileção pela literatura dramática em Sêneca e pela desconfiança em relação ao teatro profissional em São Tomás de Aquino, Bacon, Göethe e Rousseau. Na perspectiva contrária, Patrice Pavis, fazendo referência à noção de encenação surgida em meados do século XIX, afirma que "com a emergência da encenação e a conscientização de sua importância para a compreensão da peça, o espetáculo reencontra direito de cidadão" (PAVIS, 1999, p. 141).

A montagem de um espetáculo teatral com intenções educativas se constitui historicamente no modus operandi das "pedagogias do espetáculo", presente no "teatro escolar" de Bacon e Göethe, no teatro catequizante dos jesuítas e, ainda hoje, na visão paradigmática das artes cênicas dentro das escolas de Educação Básica no Brasil. O objetivo tanto pode estar na formação do sujeito (Bacon e Göethe), como no aprendizado de conteúdos transversais (a fé cristã ou o perigo

\footnotetext{
${ }^{25}$ Para Denis Guénoun, "a invenção do encenador, sem dúvida, nada mais é do que a vontade de colocar um espectador determinado no lugar do espectador e dotá-lo de todos os poderes" (GUÉNOUN, 2004, p. 87).
} 
das drogas) ou de outras disciplinas escolares (o latim ou a obra de Graciliano Ramos), na aquisição de conhecimentos culturais como bem de troca e de status social (as reais intenções do filisteu, como denunciava Hannah Arendt) e, mais prosaicamente, como atividade festiva, comemorativa e/ou de entretenimento para datas especiais dentro das escolas.

Quando realizada no contexto escolar a ênfase dada ao espetáculo, àquilo que se vê, com a intenção formativa direcionada aos espectadores e com objetivos educativos externos à linguagem teatral, tende a se descuidar dos aspectos pedagógicos voltados àqueles alunos que fazem o espetáculo. Não há preocupação alguma com o aprendizado da atuação, escolhendo-se para esta aqueles alunos vistos como mais desenvoltos para a cena. Tecnicamente, exige-se, a priori, articulação vocal clara aliada à boa potência sonora e ainda a facilidade para a memorização dos textos, deixando-se a cargo do pressuposto talento individual do aluno a arte da atuação. O texto dramático, em geral, não é produzido na escola ou, quando o é, fica a cargo de um professor ou de um aluno reconhecidos como talentosos no manejo da palavra escrita. Dificilmente existe o sentido da encenação como arte, pois, em geral, se reproduzem formas referenciadas como teatro "bem feito".

A referência a formas tidas como "corretas" atravessa todo o processo pedagógico e de criação teatral dentro das escolas, pois se busca na atuação, na dramaturgia e na encenação os resultados já vistos em outros contextos. Assim, quando existe uma intenção educativa em relação aos atuantes, esta é vista como consequência da própria atuação ou como pré-requisito a ela. Francis Bacon e Göethe, nos exemplos citados acima, afirmavam que a atuação fortaleceria a memória, a voz e a pronúncia, agindo na disciplina interna e corrigindo a fisionomia e os gestos (COURTNEY, 2003, pp. 12 e 16). Ambos se referem a aspectos técnicos do ofício do ator, o que significa dizer que nas "pedagogias do espetáculo" os modos pedagógicos para o aprendizado da "escrita" teatral, quando existem, são aqueles próprios à formação no ofício de ator, dramaturgo e encenador.

Esse modo pedagógico que se realiza no espetáculo cênico tanto pode se inserir em uma abordagem essencialista em que o aprendizado da linguagem teatral é realçado, porém somente em sua natureza de produto final - na qual o processo 
de aprendizagem se pauta somente na formalização de uma ideia concebida a priori pelo(s) criador(es) -, como também em abordagens contextualistas, que veem no teatro a possibilidade do aprendizado de temas transversais e de conteúdos específicos de outras disciplinas.

\subsubsection{Pedagogias da educação dramática}

As posições contrárias ao aprendizado do ofício teatral dentro do âmbito escolar muitas vezes se voltam ao seu caráter espetacular, revelando uma modalidade que reduz a linguagem teatral à dramatização. Caso se entenda a mimese aristotélica não somente como uma imitação irrefletida, mas como a capacidade humana de colocar-se na situação do outro, a afirmação de que "o imitar é congênito no homem ([...] e, por imitação, aprende as primeiras noções)" (ARISTÓTELES, 1987, p. 203) indicaria uma predisposição para a dramatização, que atuaria como operador privilegiado na aprendizagem. "A característica essencial do homem é sua imaginação criativa" (COURTNEY, 2003, p. 3) e esta "é essencialmente dramática em sua natureza" (p. 3). Baseando-se nesse princípio, Courtney defende que "a educação dramática deve ser ajudada e assistida por todos os métodos modernos de educação" (p. 4) e, a partir dessa formulação, aqui se chamarão a esses modos pedagógicos, para melhor compreensão do todo, de "pedagogias da educação dramática".

Na introdução ao seu livro Jogo, teatro e pensamento, Courtney assinala que, para ele, a Educação Dramática não é um treinamento para o palco, mas sim, "em essência, [...] é a criança jogando dramaticamente" (p. XIX), e dá como exemplos desse "jogo dramático" as brincadeiras de rua, como "mocinho e bandido", e uma menina conversando com suas bonecas enquanto as veste. A brincadeira e o jogo dramáticos como operadores educativos são herdeiros de uma linhagem do pensamento europeu que remete a Platão, Aristóteles, Rabelais e Rousseau. Observe-se que para esses pensadores a educação dramática é indicada em processos pedagógicos, mas não necessariamente a arte teatral, pois Platão excluiu o teatro de sua República, mas não o jogo educativo; Aristóteles, como já foi dito, 
considerava o espetáculo como a parte menos artística da tragédia; Rabelais indica "trezentos e dezesseis jogos para exercitar a mente e o corpo e [...] introduz canto, dança, modelagem, pintura, estudo da natureza e trabalho manual" (p. 10) para a educação de Gargântua, omitindo a arte teatral; e Rousseau, como também já foi sublinhado, desconfiava do ofício teatral como instrumento pedagógico.

Courtney, nesta perspectiva, propõe uma distinção de termos para a compreensão das pedagogias da educação dramática no contexto escolar: teatro seria a representação "perante uma plateia" (p. XX); jogo (em inglês, play) a "atividade a que nos dedicamos simplesmente porque a desfrutamos" ( $\mathrm{p} . \mathrm{XX}$ ); jogo dramático (em inglês, dramatic play) o "jogo que contém personificação e/ou identificação" (p. XX); e jogo de regra (em inglês, game) a "formalização do jogo em modelos com regras" (p. XX). Assim, "a Educação Dramática está baseada no jogo dramático [dramatic play] que é adotado em uma escola visando favorecer o desenvolvimento da criança" (p. XX). Courtney distingue ainda dois componentes da Educação Dramática na escola, o Método Dramático, voltado à aprendizagem de várias disciplinas, e o Teatro como tal: "jogo dramático com fim em si mesmo, voltado apenas para o desenvolvimento pessoal da criança" ( $p$. XXI), no qual se inserem como matérias de estudo a improvisação, o movimento criativo, o discurso criativo e o teatro (ou teatro escolar). Esse educador fundamenta a educação dramática na antropologia, psicologia social, psicanálise e psicoterapia infantil e indica suas origens "nas modernas teorias do conhecimento, nas teorias behavioristas da imitação, na psicolinguística e na psicologia do desenvolvimento de Piaget" (p. XXI). Como se vê, tanto as matérias de estudo como as referências disciplinares não se referem a poéticas ou técnicas próprias da linguagem teatral.

Inspiradas nas proposições pedagógicas do "aprender fazendo", de John Dewey, estariam dentro do âmbito da Educação Dramática propostas como a de Caldwell Cook e seu play way ou método dramático, a de Winifred Ward e os Creative Dramatics, e a de Peter Slade e o "jogo dramático infantil" (em inglês, child drama). Dessa maneira, a Educação Dramática, para Courtney,

abarca todas as abordagens dramáticas criativas da educação. Admite que o teatro infantil existe e é o método pelo qual a criança cresce e amadurece. Reconhece que a imaginação dramática capacita a criança (e o adulto, de uma outra maneira) a ver a relação entre ideias e sua mútua inter-ação, e que, através da personificação e 
identificação, a criança pode compreender e apreender o mundo que a rodeia. Dessa maneira, é importante que ela possa se expressar através do movimento criativo e do discurso e linguagem espontâneos, e também que use estes na identificação, para relacionar-se com o seu meio. Além disso, a Educação Dramática considera que as disciplinas relativas ao teatro permitem ao adolescente e ao adulto, sob certas condições, crescerem e se desenvolverem da mesma maneira que o jogo dramático auxilia a criança pequena [p. 56].

Influenciadas pelas pedagogias progressistas do século XX e sua perspectiva pedocêntrica, isto é, "a educação a partir da criança" (p. 41), as "pedagogias da educação dramática" transformam o aluno no protagonista do processo educativo. Tendo como modelo comparativo as "pedagogias do espetáculo", o eixo da aprendizagem teatral é deslocado da plateia para o palco, do espectador para o ator, da recepção para a atuação, da leitura para a escrita. Nessa mudança de eixo, o espetáculo teatral passou a ser visto meramente como uma reprodução e, desta maneira, como inadequado para a formação do sujeito, porque esta deveria estar voltada para a criação. Porém, não é possível afirmar que estas pedagogias estejam estritamente direcionadas ao aprendizado da linguagem teatral (e, portanto, à sua escrita), pois seu caráter contextualista faz do jogo dramático instrumento para o desenvolvimento emocional e psicológico do sujeito. Ao desprezar o caráter espetacular do teatro e excluir o papel do espectador, o olhar externo e 0 aprendizado distanciado do objeto, se reduz a linguagem teatral à dramatização de conteúdos subjetivos. O intuito pedagógico, na verdade, não se relaciona à linguagem teatral, mas à auto-expressão dos alunos, seu prazer e espontaneidade durante o processo de aprendizagem, o que faz com que Courtney, ao indicar procedimentos de jogo dramático para crianças de 14 anos, afirme que "quando o 'teatro' aparece, ocorre acidentalmente" (p. XX). Natural, portanto, que as "pedagogias da educação dramática" não se relacionem com a tríade ator-textoplateia e não trabalhem sobre o texto dramático ou a encenação, visto que suas modalidades se direcionam aos aspectos relativos à atuação, ainda assim de uma maneira restrita, pois somente enfatizam os aspectos expressivos sem nenhuma preocupação comunicacional e, portanto, de aprendizado dos códigos da linguagem do ator.

Atualmente, as "pedagogias da educação dramática" são pouco estudadas nas licenciaturas e em programas de pós-graduação em teatro e artes cênicas no 
Brasil, porém estas modalidades estiveram em voga no país, nas décadas de 1970 e 1980, principalmente com a tradução do livro de Peter Slade, O jogo dramático infantil (1978), o que faz com que ainda se reconheçam várias práticas e teorias afins dentro do ensino curricularizado do teatro. Saliente-se, ainda, que não se deseja, aqui, negar a brincadeira e os jogos de dramatização como importantíssimos na formação cognitiva e emocional da criança, essenciais como operadores pedagógicos para os processos de subjetivação. Porém, é preciso ressaltar que esses modos talvez não sejam os mais indicados para uma educação na linguagem teatral, por tudo o que se argumentou acima. Caso se privilegie o jogo e, por conseguinte, o prazer e a espontaneidade no processo de ensino e aprendizagem teatral, seria preciso também colocar em jogo a linguagem teatral e não somente seus aspectos dramáticos e auto expressivos. É o que propõem os adeptos do que aqui se chamará de "pedagogias do jogo improvisacional".

\subsubsection{Pedagogias do jogo improvisacional}

Interessados nos aspectos lúdicos da aprendizagem presentes nas "pedagogias da educação dramática", educadores e artistas teatrais desenvolveram modalidades pedagógicas cujo princípio norteador é o aprendizado da linguagem teatral através do jogo improvisacional. A ênfase nos elementos presentes na tríade ator-texto-encenação caracteriza essas abordagens, em princípio, como essencialistas, o que as difere da abordagem contextualista das "pedagogias da educação dramática", cujo princípio norteador é o desenvolvimento cognitivo e emocional dos participantes. Porém, como se verá mais a frente, pode-se contestar o caráter essencialista de algumas dessas pedagogias em decorrência de seus objetivos éticos e políticos.

A escolha do jogo improvisacional como operador no aprendizado da linguagem teatral tem o intuito de transpor poéticas e técnicas próprias à formação do artista da cena para ambientes educativos que visem o exercício da cidadania através do teatro e não necessariamente o ensino dos ofícios teatrais. As modalidades pedagógicas e suas abordagens baseiam-se no jogo de regras e na 
improvisação cênica, ou seja, são aplicados jogos cujas regras enfatizam os elementos da linguagem teatral para que, através da improvisação, os participantes passem pela experiência e pelo entendimento da linguagem. Flavio Desgranges (2006) descreve, de maneira sucinta, esses modos pedagógicos:

Os jogos de improvisação teatral, ou jogos improvisacionais, constituem-se em exercícios teatrais em que um ou mais jogadores-atores executam uma cena de maneira improvisada, ou seja, sem ensaio. A cena pode ser improvisada a partir de breve combinação estabelecida pelos jogadores-atores, ou mesmo sem combinação prévia, partindo-se de uma proposta dada pelo coordenador do processo. Os demais integrantes do grupo se colocam, geralmente, como jogadores-espectadores da cena apresentada. O exercício continua até que todos os integrantes do grupo apresentem as suas cenas. Normalmente, depois da apresentação das cenas, o grupo conversa e analisa a experiência [DESGRANGES, 2006, p. 87].

O aluno, ao improvisar a cena em jogo, passa pela experiência da linguagem enquanto escrita, apreendendo princípios de atuação, dramaturgia e encenação. que diferenciaria o jogo de improvisação teatral do jogo dramático, presente nas "pedagogias da educação dramática", é a adoção do jogo de regras (game) no lugar do jogo livre (play). Assim, segundo Desgranges, "a investigação teatral desenvolvida durante o processo, exorta os participantes a conhecerem e se apropriarem das possibilidades comunicacionais dessa arte. E mais, a inventarem um jeito próprio de pensar e fazer teatro..." (p. 88).

Podem-se indicar cinco modalidades que se inserem nesta perspectiva das "pedagogias do jogo improvisacional" que, no Brasil, estão presentes em diversos âmbitos educativos, integram ementas de disciplinas, conteúdos conceituais e bibliografias básicas da grande maioria dos cursos de licenciatura em teatro e em artes cênicas em todo o país e são tema de inumeráveis pesquisas em nível de pósgraduação. Trata-se do Teatro do Oprimido, dos Jogos Teatrais, do Jogo Dramático, do Jogo com a Peça Didática Brechtiana e do Drama.

O Teatro do Oprimido foi desenvolvido pelo brasileiro Augusto Boal a partir do teatro épico-dialético de Bertolt Brecht. Ainda que existisse de maneira latente nas ações desenvolvidas por Boal no Teatro de Arena, de São Paulo, em finais da década de 1960, conceitualmente sua origem se deu em um programa de alfabetização popular patrocinado pelo Governo Revolucionário Peruano, no ano de 
1973, o que contextualiza seu propósito fundamental: transferir os meios de produção da burguesia para o povo com o objetivo de, primeiro, instrumentalizá-lo na teoria e na prática política e, segundo, realizar a revolução comunista. Com o intuito de transformar o mundo, Augusto Boal propõe uma modalidade poética e pedagógica que agiria como um "ensaio da revolução", destruindo a estrutura do drama burguês.

Primeiro se destrói a barreira entre atores e espectadores: todos devem representar, todos devem protagonizar as necessárias transformações da sociedade. [...] Depois, destrói-se a barreira entre os protagonistas e o Coro: todos devem ser, ao mesmo tempo, coro e protagonistas - é o "Sistema Coringa". Assim tem que ser a "Poética do Oprimido": a conquista dos meios de produção teatral [BOAL, 2011, p. 12].

Boal representa graficamente o Método do Teatro do Oprimido através de uma árvore em cujo tronco estão os jogos, "porque reúnem duas características essenciais da vida em sociedade: possuem regras, como a sociedade possui leis, que são necessárias para que se realizem" (p. 16), e porque "ajudam à desmecanização do corpo e da mente alienados às tarefas repetitivas do dia-a-dia" (p. 16).

O sistema de Jogos Teatrais (em inglês, Theater Games, hoje renomeado como Spolin Games) foi desenvolvido pela norte-americana Viola Spolin, influenciada pela educadora Neva Boyd e pelo encenador-pedagogo russo Constantin Stanislavski. De Boyd, Spolin recebeu "treinamento em jogos, arte de contar estórias, danças e canções folclóricas" (KOUDELA, 1984, p. 40), e o interesse pelo jogo de regras (game) como operador pedagógico. Para Spolin,

qualquer jogo digno de ser jogado é altamente social e propõe intrinsicamente um problema a ser solucionado - um ponto objetivo com o qual cada indivíduo deve se envolver, seja para atingir o gol ou para acertar uma moeda num copo. Deve haver acordo de grupo sobre as regras do jogo e interação que se dirige em direção ao objetivo para que o jogo possa acontecer [SPOLIN, 1979, p. 5].

Ingrid Koudela, uma das responsáveis pela introdução do sistema de jogos teatrais de Spolin no Brasil, se apoia na psicologia genética de Jean Piaget para defender o jogo como operador na aprendizagem. $O$ jogo exige um trabalho de síntese progressiva entre a assimilação, realizada como jogo simbólico, com a 
acomodação, necessária à adaptação, requerida pela regra e pelas relações interindividuais dos "jogos de construção":

O jogo teatral, que não constitui uma estrutura na evolução genética do jogo na criança, deve ser compreendido como um "jogo de construção" que se desenvolverá no sentido de uma linguagem artística (teatro). Em oposição à assimilação pura da realidade ao eu, que caracteriza o jogo simbólico, o jogo teatral propõe um esforço de acomodação, através do processo de solução de problemas (interação com o outro) [KOUDELA, 2010, p. 166].

O sistema de Viola Spolin "propicia a alfabetização na linguagem artística do teatro, mediante a exploração e descoberta de unidades mínimas" (p. 166) através das regras dos jogos que operam na estrutura dramática ou, mais especificamente, naqueles elementos que se referem à arte do ator, que são o papel/personagem (quem), a ação (o quê) e o lugar (onde). A partir desses três elementos, se retoma a tríade de Lope de Veja, porque os participantes (jogadores/atores) improvisam sobre um problema dado (foco/"paixão") para uma plateia (palco/tablado) composta também por participantes. Maria Lúcia Pupo afirma que

Spolin - visivelmente marcada pela influência de Stanislavski no período final de sua vida, quando enfatiza as ações físicas como eixo da formação do ator - formula seus dispositivos de aprendizagem de modo a promover a chamada fisicalização, ou seja, a preocupação em tornar reais lugares, objetos, ações e personagens. A realidade da cena é a matéria com a qual se trabalha; o ato de experimentar a arte do teatro nesses moldes é encarado como formador [PUPO, 2005b, p. 219, grifo da autora].

O Jogo Dramático de origem francesa (jeu dramatique) deve ser diferenciado dos jogos dramáticos originários dos países de língua inglesa (dramatic play), sobre os quais se discorreu anteriormente, principalmente pelos objetivos de ensino e aprendizado voltados para a investigação da linguagem teatral. Seus jogos de improvisação reforçam o caráter artístico dessa investigação ao exercitarem os participantes tanto na atuação cênica como na leitura da cena, como espectadores. Também se diferenciam dos Jogos Teatrais e do Teatro do Oprimido por não se constituir em um sistema fechado e autoral. Diversos pedagogos e artistas teatrais franceses participaram do desenvolvimento dessa modalidade pedagógica, dos quais se pode citar o pioneiro Léon Chancerel e, em especial, Jean-Pierre Ryngaert, este devido ao impulso que proporcionaram duas de suas obras para a difusão do 
jeu dramatique no Brasil: O jogo dramático no meio escolar (1981) e Jogar, representar (2009).

Segundo Maria Lúcia Pupo, o Jogo Dramático foi fortemente influenciado pelas investigações artístico-pedagógicas de dois diretores teatrais, Jacques Copeau (1879-1949) e Charles Dullin (1885-1949). Copeau, ao "colocar o ator no centro do fenômeno teatral" (PUPO, 2005b, p. 224), sistematizou "diretrizes para sua formação global e progressiva, dando origem a uma verdadeira pedagogia do ator" (p. 224). Enquanto Dullin preconizou "a improvisação teatral como o caminho por excelência para que o aluno descubra seus próprios meios expressivos" (p. 224).

Quanto ao jogo, Ryngaert o concebe como um "espaço potencial", citando o trabalho do psicanalista inglês Donald Woods Winnicott:

Constatando que o jogo não provém nem da realidade psíquica interior (ele se distingue do sonho e da fantasia), nem da realidade exterior (ele não se confunde com a experiência real), que ele não está nem dentro nem fora, Winnicott o situa em uma zona intermediária, um espaço potencial definido como o campo da experimentação criativa [RYNGAERT, 2009, p. 39, grifos do autor].

O que faz do jogo "um vasto espaço de experimentação do real" (p. 40), pois jogar é fazer coisas e não somente pensar ou desejar. Segundo Ryngaert, cabe ao formador considerar o "aumento da capacidade de jogo dos indivíduos como uma maneira prioritária de trabalhar 0 real e de escapar da alternativa introversão/extroversão" (p. 42), oferecendo jogos (e não conduzindo) que propiciem o encontro de "espaços potenciais favoráveis ao trabalho" (p. 42).

Os indutores de jogo não se encontram nem totalmente no interior dos indivíduos, nem totalmente no exterior. Uma parte de nossa reflexão recai sobre as zonas intermediárias entre o dentro e o fora, sobre a manifestação de subjetividades que vão ao encontro de imagens do mundo, por ocasião do processo de criação [p. 42].

A peça didática (Lerstück) foi formulada por Bertolt Brecht em meados da década de 1920, na Alemanha, com o intuito político de formar os trabalhadores na dialética marxista através do teatro e da educação estética, socializando o acesso aos meios de produção artística dessa linguagem. Vista por muito tempo como uma parte menor na produção artística e intelectual de Brecht, a peça didática foi 
revalorizada, em finais da década de 1960, em decorrência de pesquisas realizadas por Rainer Steinweg, na então Alemanha Ocidental. No Brasil, recebeu forte impulso e difusão por meio do trabalho de investigação de Ingrid Koudela, a partir da década de 1980, que, influenciada pelas pesquisas alemãs, aproximou a teoria brechtiana à prática do jogo improvisacional de Viola Spolin.

Diferentemente das modalidades de jogos improvisacionais apresentados anteriormente, o Jogo com a Peça Didática opera sobre um texto dramático, um Modelo de Ação na terminologia brechtiana, e pela ausência de plateia externa à improvisação. Segundo Koudela,

Brecht parte do princípio de que o jogo teatral, orientado com base nos textos das peças didáticas, propicia a elaboração de experiências e acontecimentos sociais, sendo que as concepções sobre o mundo e a sociedade podem ser então aprofundadas de uma forma que só é possível mediante os elementos do teatro. A proposta de educar os jovens através do jogo teatral aponta para um caminho de autoconhecimento. O jogador atua para si mesmo e não para outrem. Atuar é ser espectador de si próprio. A peça didática ensina quando a gente é atuante e, ao mesmo tempo, espectador dos próprios atos [KOUDELA, 2010, p. 164].

Dessa maneira, o aprendizado acontece, inicialmente, no plano da corporeidade no qual "o material do teatro, os gestos e as atitudes, é experimentado concretamente no jogo" (p. 130) através de dois instrumentos artístico-pedagógicos: a construção do gestus, isto é, a corporificação das relações intersubjetivas entre os homens, e o estranhamento do conhecido, ou o espanto diante da realidade. Essa "relação de causa e efeito entre o pensamento e a sua expressão física constitui o fundamento do conceito de aprendizagem em Brecht” (p. 163).

O Drama é uma metodologia de ensino anglo-saxã, inicialmente difundida no Brasil através dos estudos de Beatriz Cabral, que consiste na improvisação de um roteiro que vai sendo revelado pelo coordenador durante o processo de criação. Segundo Desgranges, "o Drama propõe um processo coletivo de construção de uma narrativa dramática, estimulando os participantes a conceberem teatralmente uma história" (DESGRANGES, 2006, p. 125). Durante o processo vão sendo definidas as situações a serem abordadas e, em decorrência, as investigações em torno de um texto, de um conteúdo disciplinar, de um fato histórico, de uma montagem teatral, entre outros. 
Os fragmentos e/ou eventos que compõem os episódios conduzem a investigação teatral de uma narrativa que pode se dar através de jogos de improvisação, da construção de objetos cênicos, músicas, ambientes, iluminação etc. (p. 127). Dessa maneira, ocorre a apropriação dos elementos que compõem a cena e a alfabetização na linguagem teatral, mediadas pelo professor coordenador, como conclui Beatriz Cabral:

A construção do conhecimento em grupo, através da concomitante aquisição da linguagem, ambos decorrentes das situações criadas e mediadas pelo professor, fica evidente a cada etapa do processo. Neste, o sucesso ou fracasso do drama como método de ensino ou de aprendizagem reflete a habilidade do professor para coordenar as interações dos alunos em diferentes níveis a fim de equilibrar fazer e apreciar e de introduzir situações, informações e/ou desafios na hora certa de acordo com os diferentes papéis e ações [CABRAL apud DESGRANGES, 2006, p. 138, grifos da autora].

As modalidades de jogo improvisacional, porém, não podem ser resumidas a estas cinco sistematizações apresentadas. Poder-se-iam ainda citar, como exemplos, as investigações que Maria Lucia Pupo (2005a) desenvolve em torno das interseções entre o jogo teatral e textos literários, e o crescente interesse pelo sistema de view points, técnica de composição desenvolvida pela coreógrafa Mary Overlie e adaptada para a linguagem teatral por Anne Bogart e Tina Landau. E ainda a inumeráveis pesquisas desenvolvidas no Brasil que se apropriam das modalidades apresentadas acima, friccionando-as, fundindo-as, acrescentando experimentações vindas de processos de criação do teatro profissional, constituindo-se em um corpus da pedagogia do teatro voltado à iniciação nessa arte e em sua aprendizagem enquanto direito do cidadão.

Diante da longa ausência do Teatro no currículo da Educação Básica brasileira e de sua atual dificuldade em se legitimar como área de conhecimento autônoma, as "pedagogias do jogo improvisacional" ganharam força nos ambientes das ações socioculturais e na formação de educadores teatrais. Suas diferentes modalidades se colocam de maneira autônoma diante de procedimentos específicos voltados ao ensino dos ofícios teatrais, porém, ainda assim, podem (e são) incorporadas no próprio aprendizado desses ofícios. Observa-se também que muitos processos vindos de ações socioculturais ganham autonomia artística ao se inserirem em espaços antes exclusivos dos "profissionais". Bem como muitos 
coletivos teatrais desenvolvem processos de criação artística que se utilizam dessas modalidades e até mesmo da participação de não-profissionais na criação e nas apresentações públicas, diluindo as fronteiras entre o que seriam pedagogias teatrais voltadas ao ofício daquelas voltadas às ações de cidadania.

\subsubsection{Pedagogia do teatro: entre o ofício, a ação sociocultural e a Educação Básica}

As sistematizações do ensino do teatro expostas anteriormente, ou seja, a espetacularização com intenções didáticas voltadas para a fruição e recepção, as práticas auto expressivas e as modalidades das "pedagogias do jogo improvisacional", estão dentro das escolas variando a ênfase em uma ou outra de acordo com a formação do Professor de Arte e de Teatro ou das intenções pedagógicas dos gestores escolares.

As "pedagogias do espetáculo" constituem-se em paradigma no ensino das artes cênicas, como analisado no primeiro capítulo $^{26}$, por isso chegam a ser chamadas de "Teatro Escolar" por Vera Lúcia Bertoni dos Santos. A autora afirma que, como modelo pedagógico, essa abordagem

constitui, por assim dizer, o representante "clássico" do ensino tradicional, pois se relaciona, muito frequentemente, à postura diretiva do professor, confundida com a do "diretor" de teatro (também numa matriz tradicional, ou seja, "aquele que cria", "que propõe"), a determinar os propósitos e as ações cênicas em prol do resultado final - a apresentação do espetáculo teatral [SANTOS, 2012, p. 17).

Ao procurar definir as maneiras de operar dessas "pedagogias do espetáculo", Vera dos Santos aproxima as formas de produção próprias do ofício teatral a uma prática pedagógica associada ao ensino tradicional, denominando-a de "Teatro Escolar". Observe-se que na tentativa de desqualificar essas modalidades de ensino da linguagem teatral dentro da escola, a autora às associa à tradição e ao próprio conhecimento escolar, questões problematizadas no capítulo anterior.

\footnotetext{
${ }^{26}$ Ver páginas $52-54$
} 
Segundo a leitura de Courtney (2003), essas abordagens fazem parte do pensamento ocidental (eurocêntrico) desde que Aristóteles, em sua Poética, afirmou o primado do prazer da aprendizagem pela fruição da obra à sua execução. Voltadas ao aprendizado do espectador, portanto à formação ética e estética do cidadão, as "pedagogias do espetáculo" geralmente desprezam a formação dos atuantes baseadas em uma vaga ideia de "talento natural". Quando existe alguma preocupação pedagógica com o aprendizado daqueles que atuam, normalmente esta se volta a técnicas vindas do ofício teatral sem nenhuma transposição didática.

Essas pedagogias que veem o teatro somente em seu produto final quando aplicadas na Educação Básica tendem a manter em relevo os tradicionais elementos da linguagem teatral, como o texto dramático, as personagens e a encenação frontal, colocando suas formas mais reconhecíveis e aceitas como tal pelo senso comum. Em geral, procuram reproduzir os modos de produção de um teatro profissional estritamente ligado ao mercado e, portanto, dependente da renda da bilheteria e/ou de grandes patrocínios de empresas privadas para sua sobrevivência, copiando também suas soluções formais. Quando não tomam como teatrais formalizações artísticas vindas de outras linguagens artísticas e midiáticas, como o cinema e a televisão. Soluções estéticas que, inseridas em uma economia de mercado, procuram agradar a um chamado "gosto médio", distanciando-se de investigações estéticas ou de problematizações éticas mais polêmicas. Assim, ainda que preservem os elementos da linguagem teatral em seu processo pedagógico, estes, em geral, são esvaziados de seus próprios sentidos, pois são cópias de um suposto teatro "bem feito". Não existe nenhuma preocupação com a transposição didática dos saberes relacionados ao ofício para os saberes necessários à formação cidadã dos atuantes. De certa maneira, e como já foi dito anteriormente, as "pedagogias do espetáculo" servem tanto à instrumentalização do teatro dirigida para outras áreas do conhecimento, como também são uma faceta do que Hannah Arendt chamou de filisteísmo cultural, ou seja, o objetivo não é a aprendizagem da linguagem teatral, mas a visibilidade de um suposto refinamento cultural que se constituiria em valor de troca social.

A ênfase no produto final espetacular faz com que seu processo de produção seja realizado através da divisão e execução de tarefas previamente estabelecidas 
que, muitas vezes, impossibilitam a criação individual ou coletiva e o entendimento do todo. O produto final tem sua forma estabelecida a priori e todo o processo de sua construção é direcionado a essa formalização idealizada. Ainda que os alunos percebam a existência dos elementos que compõem a linguagem teatral, sua relação com eles é de reprodução e não de estudo e experimentação de suas possibilidades. Quando a ênfase da pedagogia teatral está na apresentação pública do produto final, o estudo dos elementos da linguagem é relegado, transformando-os em instrumentos utilitários para se chegar ao objetivo final. A matéria teatro não é uma coisa colocada sobre a mesa para ser estudada, mas uma ferramenta cujas maneiras de utilização já estão previstas em um manual. Não há estudo, mas reprodução do já sabido, do já lido, do já testado.

Isabel Marques e Fábio Brazil observam que,

de modo geral, a escola parece reconhecer apenas os produtos. As exposições dos trabalhos de Arte dos estudantes - coreografias, pinturas, peças de teatro - são apresentações únicas, nas feiras culturais, nas mostras de dança do município, no encontro dos corais etc. Ou seja, o produto acaba sendo experimentado e vivido pelos estudantes como algo realmente fechado e hermético, a primeira e a última chance de se realizar o trabalho em sua completude, partilhado com a comunidade escolar. Isso, muitas vezes, compromete a escolha do tipo de trabalho a ser feito e a metodologia processo - utilizada para sua realização [MARQUES e BRAZIL, 2014, p. 95].

Contrários a essa ideia de teatro visto somente em seu produto final é que arte educadores como Peter Slade vão se voltar. Inspirados também na tradição do pensamento europeu, como se viu nas referências à obra de Richard Courtney (2003), esses educadores passam a valorizar os aspectos dramáticos presentes na linguagem teatral como forma de estimular o desenvolvimento da personalidade das crianças. Adeptos do "deixar fazer" educacional, o teatro dentro da escola é visto somente como expressão dramática dos atuantes, abolindo-se qualquer possibilidade de formalizações, como textos estabelecidos a priori ou a posteriori e a apresentação de qualquer produto final. Aliás, abole-se a ideia de apresentação e de qualquer tipo de produto codificado que possa ser reproduzido e valoriza-se a improvisação livre, o jogo sem regras, a pura expressão espontânea. Como observa Jorge Coli, “o que é grave nas ideias de 'espontâneo', de 'sensibilidade inata', é que elas impedem uma relação mais elaborada com a obra de arte, o esforço necessário para um contato mais rico com ela" (COLI, 1995, p. 119). Pode-se afirmar que esta 
tendência, ao afastar-se de qualquer possibilidade de codificação e comunicação, distancia-se da própria possibilidade de existência de uma linguagem. A linguagem teatral perde seus referenciais linguísticos que a tornam uma área de conhecimento para ser utilizada somente como instrumento do campo da psicologia, pois sua existência está condicionada ao desenvolvimento cognitivo e emocional dos alunos. Como aprendizado escolar, as "pedagogias da educação dramática" não apresentam nenhum conteúdo conceitual ou prática artística a ser apreendida. Não é o mundo que é colocado em estudo, mas o próprio aluno que se torna sujeito e objeto de sua aprendizagem, abandonado aos seus conteúdos interiores e impedido de colocar sua identidade em choque com o mundo, refém de si mesmo.

Contrários à perspectiva do "deixar fazer" na pedagogia, que impossibilita a própria existência da linguagem teatral, porém adeptos da ludicidade, da espontaneidade e do "aprender fazendo" em processos de aprendizagem, as "pedagogias do jogo improvisacional" procuram aproximar o aluno aos elementos da linguagem de maneira prazerosa. Ao se voltarem contra o jogo livre, essas modalidades formularão metodologias e abordagens apoiadas no jogo com regras. As regras são estabelecidas de forma que, ao se jogar, os elementos da linguagem teatral sejam colocados em relevo de forma que os jogadores/atuantes possam vivenciar processos de criação teatral. Se a construção de um produto final a ser apresentado não se constitui em objetivo dessas práticas, a criação de pequenas cenas improvisadas para uma plateia interna, constituída pelos próprios participantes, pressupõe a apreensão de códigos da linguagem teatral a serem compartilhados.

Ainda que apresentem uma crescente autonomia artística, não se pode negar que as "pedagogias do jogo improvisacional" sejam herdeiras de investigações desenvolvidas inicialmente para a cena profissional, como os traços da encenação épica brechtiana presentes no Teatro do Oprimido de Boal; o foco na arte do ator através das "ações físicas" de Stanislavski, estruturais no sistema de Jogos Teatrais de Viola Spolin; os indutores voltados à atuação como elemento da encenação no Jogo Dramático francês; a teoria do teatro épico-dialético de Brecht e sua dramaturgia como material de improvisação no Jogo com a Peça Didática; e a ênfase na narrativa dramática desenvolvida no Drama. Essas heranças justificam a 
proposição de que houve uma espécie de "transposição didática" de poéticas e técnicas de grandes artistas e de formas estéticas teatrais para ambientes socioculturais e que, hoje, essa "transposição" não só se apresenta de maneira autônoma diante da cena profissional, como, por vezes, refaz o caminho em sentido inverso, tornando-se metodologias voltadas ao ensino do ofício teatral. A ênfase didática dessas abordagens está no aprendizado prático, no fazer, que condiciona o aprendizado teórico realizado através do olhar do espectador interno.

Considerando que transposição didática é "uma transformação de saberes que ocorre nas diferentes práticas sociais, em função da diversidade dos gêneros discursivos e dos interlocutores aí envolvidos" (POLIDORO e STIGAR, 2009, p. 155), seria o caso de se perguntar se esse saber prático das "pedagogias do jogo improvisacional", transpostas do ofício para as ações socioculturais, seria também o mais indicado para a Educação Básica, visto se tratarem de interlocutores e de ambientes educativos diferenciados.

\subsection{Teatro e Educação: entre a ação sociocultural e a Educação Básica}

A área de estudos da Pedagogia do Teatro é ampla, indo da formação no ofício à formação estética do cidadão em ambientes educativos formais e não formais. Compreende as relações entre a educação e o teatro, desde o caráter educacional de sua prática aos princípios e métodos de ensino e aprendizagem de técnicas e poéticas voltadas à atuação no teatro profissional e amador. Segundo o Programa de Pós-graduação em Artes Cênicas, da Escola de Comunicações e Artes da Universidade de São Paulo (ECA-USP), esta área de concentração enfoca "a prática teatral enquanto experiência relevante na formação do indivíduo, e também os processos voltados para o aprimoramento técnico e reflexivo do artista de teatro" (USP, 2015). O Grupo de Estudos de Pedagogia das Artes Cênicas, da Associação

Brasileira de Pesquisa e Pós-graduação em Artes Cênicas (ABRACE), que tem como objeto de pesquisa "processos e práticas de educadores, educandos, artistas e espectadores nos diferentes espaços de educação - formal, informal e não-formal" (ABRACE, 2015), elenca doze (12) áreas de interesse, dentre as quais, Teatro na 
Escola de educação básica, Teatro e comunidade, Formação do artista cênico (ator, encenador, cenógrafo, figurinista etc.) e Jogos Teatrais/Jogos Dramáticos.

A diversidade de perspectivas educacionais, âmbitos de ensino, objetivos pedagógicos e métodos de pesquisa e investigação reunidos em um único grupo de estudo podem, por um lado, fazer com que se escape, segundo Koudela, "do risco de reducionismos e camisas de força didáticas, entendendo o ensino de teatro na sua complexidade" (KOUDELA, 2003, p. 17), mas, por outro, incorrer em generalizações e sobreposições nas quais áreas de interesse menos "nobres" para a investigação artística, como o teatro na Educação Básica, sejam sufocadas em suas singularidades. Assim, algumas divisões parecem ser necessárias para o estudo das especificidades de cada área de interesse, desde que não se criem as "camisas de força" citadas por Ingrid Koudela (2003).

O Programa de Pós-graduação em Artes Cênicas, da ECA-USP, divide a área de concentração Pedagogia do Teatro em duas Linhas de Pesquisa, uma voltada à Formação do Artista, que "enfoca as diferentes concepções, metodologias e conteúdos que constituem os processos de ensino/aprendizagem do artista teatral contemporâneo" (USP, 2015), enquanto a outra, Teatro e Educação, se propõe

a investigar o teatro enquanto atividade educacional, enfocando-o a partir de diferentes abordagens. Compreende, assim, a atuação do teatro enquanto prática de ensino, enfatizando as variadas questões referentes às concepções e metodologias que se preocupam com a aprendizagem do teatro na escola e em variadas instituições educacionais e culturais. Compreende, também, a prática teatral enquanto forma de ação cultural, pensando a relação entre arte teatral e sociedade em nossos dias, tanto no âmbito da democratização cultural, quanto nas possibilidades do teatro enquanto instrumento de transformação social. Compreende, ainda, as questões e práticas que abordam a formação de espectadores teatrais, enfocando o tema em seus variados aspectos, tanto no que se refere às diferentes propostas de mediação cultural voltadas para a formação de público, quanto às práticas artístico-pedagógicas que visam capacitar os espectadores. Nesse sentido, abarca também os estudos da Recepção no teatro, contemplando a atividade do espectador diante do espetáculo e o modo como pode utilizar os materiais cênicos apresentados pelos criadores para transformálos em experiência estética [USP, 2015, grifos nossos].

Como se pode ver, Teatro e Educação ainda que se diferencie da Formação do Artista continua a apresentar uma grande diversidade de objetos de estudo, tal como a grande área da Pedagogia do Teatro, o que se deve, talvez, à sua ainda recente legitimação como linha de pesquisa acadêmica. Ingrid Koudela escreve que 
"nos inícios da década de setenta, [ela] utilizava a grafia Teatro/Educação" (KOUDELA, 2003, p. 16), utilizando a barra como forma de "deixar em aberto relações a serem tecidas através do binômio" (p. 16). Posteriormente, ainda durante a década de 1970, passou-se a grifar Teatro-Educação em decorrência da aceitação que o termo Arte-educação teve no país com a realização dos congressos da $F A E B$ - Federação de Arte-Educadores do Brasil. Em 2001, no II Congresso Brasileiro de Pesquisa e Pós-graduação em Artes Cênicas, da ABRACE, será criado o grupo de trabalho Pedagogia do Teatro e Teatro na Educação.

O painel histórico apresentado anteriormente a partir da obra de Richard Courtney (2003) mostra que as relações entre teatro e educação tencionam-se entre os polos do ofício e da formação do indivíduo, ora negando o ofício, como em Bacon, Göethe, Rousseau e as "pedagogias da educação dramática", ora negando as perspectivas pedagógicas voltadas exclusivamente ao desenvolvimento psicológico, cognitivo e comportamental do homem. É nas "pedagogias do jogo improvisacional" ao se aproximarem da linguagem do teatro e das artes de seu ofício que se insere grande parte das pesquisas em Teatro e Educação realizadas neste século no Brasil. Esta aproximação revela-se no momento em que os pesquisadores da área criam um grupo de estudo dentro de uma associação de pesquisadores em Artes Cênicas (ABRACE) e não em uma associação voltada à Educação, e também através da criação de uma linha de pesquisa em pós-graduação em um curso de Artes Cênicas e não em uma pós-graduação em Pedagogia. Como afirma Koudela:

O intuito de incorporar reflexões e indagações sobre a Pedagogia do Teatro visou não apenas ampliar o espectro da pesquisa na área, trazendo para a discussão os Mestres do Teatro - dramaturgos, teóricos e encenadores, como também fundamentar a epistemologia e os processos de trabalho do teatro, inserindo-os na história da cultura [KOUDELA, 2003, p. 17].

A aproximação da linha de pesquisa Teatro e Educação à área da Pedagogia do Teatro com a intenção de dar ênfase aos estudos da linguagem teatral em ações educativas, se, por um lado, distanciaram-na de perspectivas pedagógicas voltadas exclusivamente ao desenvolvimento psicológico dos atuantes, por outro, provocou um processo de fricção e acomodação da área entre os profissionais da cena, como observa Maria Lúcia Pupo: 
$\mathrm{Na}$ expectativa de assegurar para si mesmos uma certa "reserva de mercado", não são poucos aqueles que atribuem ao nosso fazer uma conotação de faceta menor de um suposto "verdadeiro" teatro. Nossa atuação, por estar vinculada a uma dimensão pedagógica se distinguiria assim de uma outra, a dos artistas agraciados com a suma dádiva do "dom", desvinculados de compromissos com a formação do homem [PUPO, 2001, p. 32].

Ao propor uma reflexão para além da dicotomia ofício e ação sociocultural, Pupo lembra a amplitude do fenômeno teatral: "Com efeito trata-se de uma modalidade artística que recobre grande multiplicidade de abordagens possíveis ( $p$. 32), dentre elas, "a ampliação do potencial daquele que atua 'como se', independentemente do fato de que essa atuação se dê pelo prazer de jogar ou se dê para ganhar a vida..." (p. 32). Citando diretores teatrais como Stanislavski, Grotowski e Eugênio Barba, Pupo argumenta que suas ações artísticas são também pedagógicas, pois "de modo radical eles sempre associaram a depuração de sua arte ao desenvolvimento pessoal daqueles que a praticam" (p. 33). Cinco anos depois desse artigo, na apresentação ao livro de Flavio Desgranges dedicado em grande parte às "pedagogias do jogo improvisacional", Pedagogia do teatro: provocação e dialogismo (2006), Pupo retoma sua crítica, agora em um momento em que não somente as ações socioculturais na área do teatro estavam permeadas por essas modalidades pedagógicas, como também estas passaram a operar até mesmo na criação teatral:

Se a alguns artistas e responsáveis de instância públicas e privadas ainda interessa estabelecer pretensas fronteiras estanques entre a educação e a ação sociocultural por um lado e a criação artística por outro - de modo talvez a manter privilégios e a assegurar prerrogativas consagradas pelo tempo - muitos dos mais interessantes processos de trabalho teatral que podemos acompanhar em nossos dias constituem a demonstração mesma da não-pertinência da fixação desses limites [PUPO, 2006, p. 12].

Os processos de trabalho teatral a que se refere Pupo surgem no intenso diálogo que se estabeleceu entre ações socioculturais e criação teatral, principalmente na cidade de São Paulo neste início de século. Em artigo dedicado às contrapartidas sociais presentes nos projetos de grupos de teatro contemplados pelo Programa Municipal de Fomento ao Teatro da Cidade de São Paulo, Pupo analisou projetos ganhadores em três edições do Programa ao longo de dez anos, 
de 2002 a 2011, nos quais se observa a presença de modalidades voltadas aos três campos de estudo da linha de pesquisa Teatro e Educação (como definidos pelo Programa de Pós-graduação da ECA-USP), a escola, as ações culturais e a formação do espectador, e ainda à formação no ofício dos integrantes do grupo proponente porém compartilhada com a comunidade. Para além da ideia de ensino da linguagem, os projetos dos grupos teatrais de São Paulo visavam "fazer avançar um trabalho artístico que possibilitasse a formação de discursos cênicos por parte de pessoas até há bem pouco apartadas desse universo" (PUPO, 2012, p. 156).

O epicentro do fenômeno teatral, tal como vem sendo experimentado em São Paulo dentro dos coletivos nos últimos anos, se desloca da encenação. O processo criativo deixa de se restringir à montagem, que passa a ser apenas uma de suas facetas. $O$ teatro transborda, portanto, de suas margens até aqui consagradas: a reflexão sobre o processo de criação, a realização de oficinas, viagens, encontros, ensaios abertos, intervenções nos ambientes urbanos ampliam a envergadura daquilo que a cena dá a conhecer [PUPO, 2012, p. 153].

Pupo observa "relações fortes com o ensino do teatro levado a efeito nas universidades" (p. 159), detectando um processo de desenvolvimento na oferta de oficinas que, em 2002, "aparece descosida do projeto artístico em seu conjunto" (p. 162), e nas edições de 2007 e 2011 são anunciadas "em proporção relativamente menor, mas, por outro lado, ganham em densidade" (p. 163). No período de onze anos em que Pupo produziu os três artigos citados, a área de Teatro e Educação passou da rejeição inicial de alguns setores à sua incorporação aos processos de trabalho e parte de processos criativos em teatro, pelo menos no caso dos grupos de teatro da cidade de São Paulo. Arão Paranaguá de Santana observa que "nessa trajetória construtiva de uma língua própria, o ensino do Teatro foi inserindo-se num campo que transcende à questão da escolaridade, situando-se em fronteiras que o levam à ação cultural e a outras possibilidades de desenvolvimento da consciência cidadã" (SANTANA, 2009, p. 31).

Não se pode ignorar a influência que os trabalhos de investigação teatral realizados na cidade de São Paulo exercem no país, por isso é preciso sempre relativizar algumas totalizações em que se pode incorrer. A aproximação do Teatro e Educação em suas abordagens voltadas às ações socioculturais e à formação do espectador aos processos profissionais de criação teatral pode dialogar com o 
ensino do teatro na Educação Básica do Brasil, porém não pode pautá-lo. A problematização que Masschelein e Simons realizam sobre os ambientes virtuais de aprendizagem pode nos servir de referência para se analisar esta questão. A dupla de educadores se pergunta:

Quando a aprendizagem se reduz à produção de resultados de aprendizagem; quando a produção de resultados de aprendizagem se torna, simplesmente, uma descrição diferente para a conversão do potencial em competências; quando existem inúmeros caminhos de aprendizagem formal e informal e ambientes de aprendizagem que tornam possível esse processo de produção - qual é, então, o papel da escola? [MASSCHELEIN e SIMONS, 2013, p. 20].

Transpondo a questão para o ensino do teatro na Educação Básica: se a aprendizagem teatral através da ação sociocultural vem apresentando resultados tão expressivos e se estas ações possuem o tempo, o espaço e a disponibilidade necessários para que esse aprendizado aconteça, por que, um, transpô-la para a escola, onde não serão encontradas as mesmas condições favoráveis? E, dois, de que serviria o ensino do teatro dentro das escolas se se pode oferecê-lo em ambientes extracurriculares com melhor qualidade pedagógica e artística? O que se percebe é que tais questões não levam em consideração o sentido da escola, mas sua funcionalidade ou expectativas de ensino estabelecidas a priori.

Se em um momento histórico foi preciso distinguir as ações educativas voltadas à formação no ofício daquelas voltadas à cidadania, talvez hoje seja necessário distinguir nas ações voltadas exclusivamente à cidadania, aquelas próprias às ações socioculturais, daquelas necessárias ao âmbito da educação básica.

\subsubsection{Abordagem triangular e "pedagogias do jogo improvisacional"}

Um olhar sobre a aprendizagem triangular, de Ana Mae Barbosa, que se tornou a base orientadora metodológica dos Parâmetros Curriculares Nacionais para o ensino e a aprendizagem de Arte na Educação Básica brasileira, relacionando-a aos modos de operar das "pedagogias do jogo improvisacional", pode nos servir 
como referência para o estabelecimento de algumas distinções entre educação formal e ação sociocultural. Ana Mae Barbosa propõe uma maneira triangular para a abordagem pedagógica de objetos e de processos artísticos através de distintos âmbitos de experiência que estão apresentados nos PCN-Arte como experiências de fazer e de fruir formas artísticas e experiência de investigar sobre a arte como objeto de conhecimento: "A aprendizagem artística envolve, portanto, um conjunto de diferentes tipos de conhecimento, que geram diferentes significações, exercitando no aluno a possibilidade de perceber-se como agente de transformações" (BRASIL, 1998, p. 36).

Fazer, fruir e investigar devem integrar os processos de apreensão das linguagens artísticas, ficando ao professor o encargo de escolher qual das três ações deve ser enfatizada a cada matéria estudada. Pretende-se com essa abordagem ampliar o sentido da arte na Educação Básica, pois, anteriormente, com a matéria educativa Educação Artística, o estudo restringia-se a atividades de produção, nas quais a fruição e a investigação, quando existiam, baseavam-se mais na percepção e análise da expressão dos alunos do que nas possibilidades comunicacionais da obra. A partir desse quadro de referências, entende-se que o aprendizado da linguagem teatral na Educação Básica, segundo os PCN-Arte, deve envolver

não apenas uma atividade de produção artística pelos alunos, mas também compreender o que fazem e o que os outros fazem, pelo desenvolvimento da percepção estética, no contato com o fenômeno artístico visto como objeto de cultura na história humana e como conjunto organizado de relações formais [BRASIL, 1998, p. 43].

As três experiências formadoras podem ser entendidas de diversas maneiras. O fazer pode se referir tanto à escrita, como à produção e criação de objetos artísticos; o fruir pode ser entendido como leitura, recepção e apreciação; e o investigar como pensamento, reflexão e contextualização. A aprendizagem artística na Educação Básica deveria passar necessariamente pela experiência nestas três ações para o entendimento da Arte como área de conhecimento e como linguagem. Sob este princípio conceitual presente nos PCN-Arte, pressupõe-se que a aprendizagem das linguagens artísticas deva envolver a aquisição de três saberes 
concomitantes: saber escrever, saber ler e saber pensar sobre. Espera-se, assim, que o aluno aprenda a utilizar as "linguagens como meio de expressão, informação e comunicação em situações intersubjetivas, que exijam graus de distanciamento e reflexão sobre os contextos e estatutos de interlocutores; e saber colocar-se como protagonista no processo de produção/recepção" (BRASIL, 2000, p. 10). No caso da Arte, as linguagens artísticas são consideradas em seus aspectos estéticos e comunicacionais: "por ser um conhecimento humano articulado no âmbito sensívelcognitivo, por meio da arte manifestamos significados, sensibilidades, modos de criação e comunicação sobre o mundo da natureza e da cultura" (BRASIL, 2000, p. 48). Para o aprendizado da linguagem teatral, os PCN-Arte recomendam que

É sempre desejável que haja uma integração entre a produção e a apreciação artística. O importante a ser ressaltado é que toda prática de teatro deve ter como base a observação, a pesquisa e o entendimento de que os textos dramáticos, as formas de representação e as formas cênicas têm tradições inseridas em diversas épocas e culturas que podem ser objeto de estudo e transformações no contexto presente do aluno [BRASIL, 1998, p. 89].

As "pedagogias do jogo improvisacional" poderiam somente elas, assim como fazem na ação sociocultural, estabelecer processos educativos na Educação Básica que atendam aos objetivos expressos nos PCN-Arte? E quanto aos sentidos da escola e suas formas de operar sobre o conhecimento, nas perspectivas de Arendt, Masschelein e Simons, apresentadas anteriormente, seriam essas metodologias capazes de apresentar o mundo aos alunos?

Se o sentido da escola é propiciar uma espécie de suspensão do tempo para que o mundo possa ser aberto e estudado pelos alunos, talvez não seja esse o âmbito educativo mais apropriado para a criação de novos mundos, e sim para o aprendizado do velho mundo em que vivemos. Já se disse que na escola não se faz ciência, mas se estudam as produções da ciência. Na escola, não se faz Biologia, estuda-se e, se necessário, se reproduz experimentos consagrados pelas ciências biológicas. Masschelein e Simons afirmam que não se trata de expulsar da escola as aplicações de conhecimento e competências, porém

só depois de serem apresentadas como matérias. Esse conhecimento e essas habilidades são, assim, libertados, isto é, separados dos usos sociais convencionais, atribuídos na medida em que são apropriados para eles. Nesse sentido, a matéria 
sempre consiste em conhecimentos e competências autoindependentes [MASSCHELEIN e SIMONS, 2014, p. 32].

Nesta perspectiva seria possível aprender Teatro sem antes fazer teatro? Na abordagem triangular a experiência do fazer (do criar, do produzir e do, enfim, escrever teatro) deve integrar o processo de aprendizagem da linguagem teatral. As "pedagogias do jogo improvisacional", por sua vez, apoiam-se no fazer, pois primeiro se joga, isto é, se produz algo para que se possa apreciar e refletir sobre essa produção. A questão que se coloca é: se a escola não é o local apropriado para a criação, mas sim para a apresentação do mundo, seria possível uma educação teatral sem a produção cênica? Ou, pelo contrário, como afirmam Isabel Marques e Fábio Brazil (2014, p. 81), a escola precisaria se adequar às necessidades da arte?

Segundo os PCN-Arte,

Produzir refere-se ao fazer artístico (como expressão, construção, representação) e ao conjunto de informações a ele relacionadas, no âmbito do fazer do aluno e do desenvolvimento de seu percurso de criação. $O$ ato de produzir realiza-se por meio da experimentação e uso das linguagens artísticas [BRASIL, 1998, p. 50].

O aprendizado de qualquer linguagem passa, necessariamente, por sua apropriação através do fazer. O domínio da língua portuguesa ou de qualquer outra língua que se estruture também na forma escrita passa pelo exercício da escrita, da criação de textos. Assim, se a escola não é o local apropriado para se fazer ciência, talvez não se possa afirmar o mesmo quando se trata do aprendizado de linguagens, pois sem a prática através do exercício de produção, a apropriação de qualquer linguagem será parcial. O problema, talvez, seja da ênfase dada ao escrever e ao ler, pois, quando se diz que alguém é alfabetizado, se diz que a pessoa sabe ler e escrever. Em reflexões realizadas após a conclusão de um projeto de formação do olhar para o teatro, os integrantes da Cia. Teatro Balagan, da cidade de São Paulo, afirmam que

numa formação em teatro o elemento principal é o estímulo à expressão - ou melhor, à auto-expressão. Subjuga-se a compreensão de que para saber expressar-se, para ser criador de uma matéria cênica, é necessário o domínio de um vocabulário; assim como para 'escrever' é necessário saber 'ler'. Podemos observar que a prática de "leitura da obra" não é relevante nos processos de 'aprendizagem' do teatro [BALAGAN, 2012a, p. 5]. 
Ainda que a alfabetização em uma linguagem pressuponha as duas ações sobre os códigos linguísticos, dificilmente pode-se escrever sem, antes, aprender a ler. Poder-se-ia estender essa afirmação a todas as linguagens? Ou seriam as linguagens artísticas e o teatro, em especial, diferentes, e para que a aprendizagem ocorra é preciso, primeiro, escrever para depois ler? A se considerar o teatro como ofício a prática é essencial, porém ao considerá-lo como linguagem a ênfase pedagógica também deveria recair no fazer ou se poderiam pensar modalidades que enfatizassem o aprendizado da leitura por meio da apresentação dos materiais?

As "pedagogias do jogo improvisacional" são intensamente utilizadas em ações socioculturais e até mesmo como iniciação ao ofício do ator e do encenador alcançando resultados expressivos como se pode constatar pelos inúmeros estudos acadêmicos produzidos sobre o tema nos programas de pós-graduação em teatro e artes cênicas no Brasil. Porém, sua aplicação na Educação Básica sem a necessária transposição didática precisa ser problematizada. Baseadas em princípios pedagógicos do "aprender fazendo" e da "solução de problemas", essas pedagogias tendem a desprezar a matéria de estudo em favor do desenvolvimento de habilidades. Era o que denunciava Arendt, referindo-se à entrada do Pragmatismo na educação que, segundo esta filósofa, pregava "que só é possível conhecer e compreender aquilo que nós mesmos fizemos, [cuja] intenção consciente não era a de ensinar conhecimentos, mas sim de inculcar uma habilidade" (ARENDT, 2011, p. 232). O estudo do teatro pode torna-se, muitas vezes, refém do fazer, da criação através do jogo da improvisação, de uma espécie de produtividade disseminada na sociedade atual, ainda que essas abordagens questionem a ênfase no produto final que seriam próprias às "pedagogias do espetáculo".

Mesmo sob uma perspectiva oriunda do Pragmatismo, a associação do "aprender fazendo" com a "solução de problemas", que privilegiaria a espontaneidade na aprendizagem, precisa ser questionada. As "pedagogias do jogo improvisacional" podem restringir-se a uma didática de cunho acumulativo de conteúdos e habilidades quando suas práticas deixam de retomar o que já foi realizado, ou seja, com o problema solucionado por meio de uma improvisação espontânea parte-se para o problema seguinte, o que poderia comprometer a 
aprendizagem. A reprodução, a repetição e a refeitura tendem a ser vistas nestas modalidades como antipedagógicas porque contrárias à educação pela espontaneidade. Richard Sennett vê nesta associação a crença na "inspiração súbita", no "talento bruto" que substituiria a prática do treinamento. Este pensador se refere à necessidade da repetição no aprendizado do ofício, problematizando a exclusão dessas práticas e procedimentos na educação formal ao afirmar que

revisar repetidas vezes uma ação, em contrapartida, permite a autocrítica. A educação moderna evita o aprendizado repetitivo, considerando que pode ser embotador. Temeroso de entediar as crianças, ávido por apresentar estímulos sempre diferentes, o professor esclarecido pode evitar a rotina, mas desse modo impede que as crianças tenham a experiência de estudar a própria prática e modulá-la de dentro para fora [SENNETT, 2009, p. 49].

Sennett observa que a repetição deve ser organizada de maneira que, "à medida que uma pessoa desenvolve sua capacitação, muda o conteúdo daquilo que repete" (p. 49). Frise-se que nesta perspectiva defendida por Sennett o desenvolvimento da capacidade de aprender e de pensar também se refere ao exercício da habilidade, visto como treinamento: "Em seus patamares mais elevados, a técnica deixa de ser uma atividade mecânica; as pessoas são capazes de sentir plenamente e pensar profundamente o que estão fazendo quando o fazem bem" (p. 30). Para Sennett, as atividades práticas são menosprezadas porque "a habilidade técnica foi desvinculada da imaginação..." (p. 31). É quando a repetição cai em um sistema fechado no qual a "solução de problemas" torna-se uma meta fixa e não um processo de "detecção de problemas".

Em outra perspectiva, a "solução de problemas" pressupõe que haja um problema a ser resolvido, a ser descoberto, a ser desnudado. Ainda que o próprio sentido do jogo pressuponha a existência de diversas formas de solução, espera-se que pelo menos uma seja "improvisada" e, quando "descoberta", possa-se passar para outro problema. Theodor Adorno e Max Horkheimer, em sua Dialética do esclarecimento, observam que essa crença em uma solução, em uma "verdade" que se esconde de nossos olhos mas que, mais dia ou menos dia, será revelada, está no cerne do esclarecimento (lluminismo).

Pois o esclarecimento é totalitário como qualquer outro sistema. Sua inverdade não está naquilo que seus inimigos românticos sempre lhe censuraram: o método analítico, 
o retorno aos elementos, a decomposição pela reflexão, mas sim no fato de que para ele o processo está decidido de antemão. Quando, no procedimento matemático, o desconhecido se torna a incógnita de uma equação, ele se vê caracterizado por isso mesmo como algo de há muito conhecido, antes mesmo que se introduza qualquer valor [ADORNO e HORKHEIMER, 1985, p. 32].

Quanto à experiência da fruição, segundo os PCN-Arte,

Apreciar refere-se ao âmbito da recepção, incluindo percepção, decodificação, interpretação, fruição de arte e do universo a ela relacionado. A ação de apreciar abrange a produção artística do aluno e a dos seus colegas, a produção históricosocial em sua diversidade, a identificação de qualidades estéticas e significados artísticos no cotidiano, nas mídias, na indústria cultural, nas práticas populares, no meio ambiente [BRASIL, 1998, p. 50].

Ler, apreciar, fruir arte é outro vértice do triangulo proposto por Ana Mae Barbosa. Desenvolver a potencialidade dos cinco sentidos para "entender" a obra teatral, criando conexões entre seus códigos e elementos. Neste sentido, Jorge Coli chama a atenção sobre a importância da frequentação à obra de arte como um "ato de interesse", de exame, observação e detalhamento do que se escuta e se vê.

Esta atitude "empírica" diante do objeto artístico permite, aliás, um controle dos textos - ela nos fornece os fundamentos de uma discussão sobre eles, de seu questionamento. E fornecendo-nos o fundamento da desconfiança do discurso, tende a Ihes neutralizar a autoridade, incitando-nos a não aceitá-los como veículo da palavra "competente". Em suma, pela frequentação evitamos delegar a outrem a nossa relação com a obra [COLI, 1995, p. 125].

A maioria das "pedagogias do jogo improvisacional" tem como princípio estruturador a presença de uma plateia formada, em geral, pelo próprio grupo de jogadores. Ao contrário das "pedagogias da educação dramática", do "deixar fazer", sem preocupação com a linguagem, no jogo improvisacional a presença da plateia, daquele que vê, é fundamental para o aprendizado. Observe-se que algumas dessas metodologias, como o Jogo com a Peça Didática de Bertolt Brecht e o Drama britânico, ainda que prescindam de uma plateia formal, passam por um processo de avaliação do jogo em que aquilo que se viu, mesmo que de dentro da cena, é colocado em questão e faz parte do processo de aprendizagem da linguagem teatral. Pensar sobre a improvisação a partir da apreensão dos códigos criados é parte do processo de formação teatral. 
A ênfase dada ao fazer nas "pedagogias do jogo improvisacional", porém, restringe o campo da percepção e da fruição do objeto artístico somente à produção dos alunos. O aprendizado e o exercício de leitura por aqueles que integram a plateia são realizados somente através de material próprio do grupo. É como se, nas aulas de Português, o exercício necessário e constante de desenvolvimento da capacidade de leitura dos alunos se restringisse somente aos textos produzidos pelos colegas, ignorando a produção literária de Machado de Assis ou a existência de textos jornalísticos, por exemplo. Esta auto-referencialização pode ser vista como uma das características da "semiformação", criticada por Adorno, que reprimiria o diferenciado em prol da uniformização da sociedade. Nas palavras de Maar, para Adorno,

os bens culturais que alimentam as massas tornam dominante o momento de adaptação, enquadrando-se numa sociedade adaptada, e rompem a memória do que seria autônomo. Perdem a capacidade de se relacionar com o outro, com algo efetivamente exterior, permanecendo apenas a capacidade de se referir à representação que eles próprios fazem desse outro externo [MAAR, 1995, p. 25].

É como se, ao aprender a escrever teatro com as ferramentas de um determinado método, o aluno só saiba escrever daquela forma, só saiba ver e fazer teatro dentro daquela gramática e daquele léxico. Existe, é claro, um projeto poético, estético, pedagógico e ético em cada um destes métodos, mas o que eles parecem não conseguir realizar é fazer com que os alunos conquistem autonomia na linguagem teatral, que pensem e ajam a partir de projetos poéticos e estéticos próprios. Dentro dos procedimentos propostos, ainda que permeados por discursos de autonomia e emancipação, as próprias abordagens podem se tornar heterônomas.

Os integrantes da Cia. Teatro Balagan citam o pensamento do educador Jorge Larrosa Bondía, presente em sua obra Pedagogia profana, para contextualizar a prática da leitura como práxis pedagógica em seu sentido emancipador:

a prática da leitura, seja esta aplicada a um texto bem como a uma obra, não se resumiria ao exercício de somar informações ou à análise de seus mecanismos de composição, mas sim "(...) um deixar dizer algo, algo que alguém não sabe nem espera, algo que compromete o leitor e o coloca em questão, algo que afeta a totalidade de sua vida na medida em que o chama para ir mais além de si mesmo, para tornar-se outro" [Larrosa]. Trata-se do exercício de leitura como uma viagem 
rumo ao desconhecido, em que cada 'leitor' é responsável pela produção de um número infinito de sentidos, que não pode necessariamente, controlar nem prever [BALAGAN, 2012a, p. 6].

É preciso, pois, incorporar ao ensino do Teatro, na Educação Básica, práticas de leitura que não se limitem aos conteúdos formais colocados em jogo pelos alunos, o que passa pela necessária frequentação a espetáculos teatrais para que o aluno possa entrar em contato com outras formas do fazer. O desenvolvimento da capacidade de leitura e seu refinamento é parte intrínseca de um projeto educativo emancipatório, caso contrário, corre-se sempre o risco de se ficar refém de discursos de competência e autoridade alheios.

Quanto à contextualização, o terceiro vértice da abordagem triangular indicada nos PCN-Arte, talvez fosse preciso pensar o jogo (a improvisação, a cena criada) e colocá-lo em conexão com outras áreas do saber. A investigação da arte como objeto de conhecimento, através de análises culturais e históricas e dos "elementos e princípios formais que constituem a produção artística" (BRASIL, 1998, p. 36), coloca em questão uma suposta pretensão de "pureza" das abordagens pedagógicas em teatro tidas como essencialistas quando no contexto da Educação Básica. A ideia de que se possa trabalhar pedagogicamente somente sobre a linguagem pode até ser interessante em contextos socioculturais ou de aprendizagem do ofício, porém é problemática quando transposta para o ensino escolar. Segundo os PCN-Arte, "contextualizar é situar o conhecimento do próprio trabalho artístico, dos colegas e da arte como produto social e histórico, o que desvela a existência de múltiplas culturas e subjetividades" (BRASIL, 1998, p. 50), fundamentais para que a escola abra o mundo para os estudos dos alunos. Mesmo que o objetivo pedagógico seja o aprendizado de uma linguagem específica, esta não está desligada do mundo. A linguagem não existe por si e em si, mas age como um instrumento de apreensão do mundo, uma forma de ler, compreender e agir.

As "pedagogias do jogo improvisacional" quando se colocam como essencialistas, alegando que seus objetivos se referem unicamente à aprendizagem da linguagem teatral, e que, por isso, evitam a contextualização do fazer, correm o risco de se fecharem nelas mesmas, enfatizando os aspectos técnicos em detrimento dos poéticos. Os modos de fazer próprios a cada uma dessas 
pedagogias quando não são colocados em questão e não são estudados comparativamente a outras poéticas teatrais podem limitar a própria potência de ação no mundo por parte dos alunos.

O Teatro do Oprimido (TO) de Augusto Boal e a Peça Didática de Bertolt Brecht, ao contrário, veem o teatro também como instrumento de luta políticoideológica. Nestas modalidades, a aprendizagem da linguagem teatral está direcionada à apropriação dos meios de produção das classes dominantes, visando à transformação do mundo. Sua adoção na Educação Básica, como método pedagógico único, incorre no que Hannah Arendt afirmava ser "o desejo de arrancar das mãos dos recém-chegados [ao mundo] sua própria oportunidade face ao novo" (ARENDT, 2011, p. 226). Já Masschelein e Simons observam que essa projeção de futuro, essa expectativa e direcionamento do aprendizado, fere o projeto democrático da escola: "A escola cria igualdade precisamente na medida em que constrói o tempo livre, isto é, na medida em que consegue, temporariamente, suspender ou adiar o passado e o futuro, criando, assim, uma brecha no tempo linear" [MASSCHELEIN e SIMONS, 2014, p. 36]. Ou, dito em outras palavras, "os anos de escola são uma fonte de medo para todos os que procuram perpetuar o velho mundo ou para aqueles que têm uma clara ideia de como um mundo novo ou futuro pode parecer" (p. 10). Dessa maneira, para eles, priva-se a geração jovem de se tornar uma nova geração, "em vez disso, os jovens tornam-se (no máximo) atores da renovação imaginada por seus pais" (p. 107).

Porém, o TO e a Peça Didática brechtiana não se constituem em uma mesma modalidade pedagógica, pois podem ser detectadas algumas diferenças entre elas que fazem da aprendizagem da linguagem teatral ora o estrito domínio sobre os meios de produção como instrumento de ação política, ora uma maneira de ver, analisar e agir sobre o mundo. No primeiro caso, situo o Teatro do Oprimido de Boal, que afirma que "o teatro deve ser um ensaio para a ação na vida real, e não um fim em si mesmo" (BOAL, 2011, p. 19). Para que este "ensaio" possa ser atualizado na "vida real", Boal seleciona cenas do cotidiano dos espectadores que revelem formas de dominação do homem sobre o homem e propõe que, através do teatro, se procure maneiras para acabar com a opressão. Trata-se, portanto, de uma pedagogia voltada à "solução de problemas", mas que não pressupõe a "detecção 
de (novos) problemas", pois o passo seguinte à "solução" encontrada é a imediata ação no mundo. Transfere-se para os alunos, no caso de sua aplicação na Educação Básica, a responsabilidade de se encontrar soluções para problemas sociais que os adultos não conseguem resolver. Em sua pedagogia de caráter pragmático, Boal não nega o acesso ao mundo através da linguagem teatral, porém, ao colocá-la como mero instrumento de ação, diminui sua própria potência de transformação, domando-a a serviço de uma causa. Segundo Masschelein e Simons,

O que é problemático sobre a politização da escola é que tanto os jovens quanto a matéria se tornam meios pelos quais os problemas sociais são encaminhados em um projeto de reforma política. [...] Se os jovens são imediatamente inseridos no velho mundo, já não permitimos a eles a experiência de ser uma nova geração [MASSCHELEIN e SIMONS, 2014, p. 110].

Já a Peça Didática de Brecht não tem como objetivo a aprendizagem da linguagem artística para utilizá-la como "ensaio da revolução", porém como forma de educação dialética do sujeito através da estética teatral. A educação político-estética é vista como formadora do sujeito, que o capacitará através do ensino e do aprendizado de instrumentos como o gestus e o estranhamento a desenvolver uma forma de pensar e agir sobre o mundo e sobre si mesmo. Assim, o jogo opera a partir de um material literário, os modelos de ação, que trazem o mundo para dentro da sala de aula e que contêm em si o aprendizado da dialética, aprendizado que só poderá ser acessado através da prática na construção dos gestus e na troca de papéis.

Interessante é analisar o jogo teatral de Viola Spolin sob uma perspectiva dialética, pois, ao não se colocar a serviço de causas políticas, deixa implícita sua perspectiva de mundo a partir de sua poética. A busca por uma representação que objetiva "tornar reais lugares, objetos, ações e personagens" [PUPO, 2005b, p. 219], negando a narratividade ("contar") em prol da fisicalização ("mostrar") [SPOLIN, 1979, p. 13], e o trabalho somente sobre conteúdos trazidos para o jogo pelos próprios jogadores através da "solução de problemas" de atuação e da aprendizagem por meio do fazer insere esta modalidade em uma perspectiva pragmática da educação, que, como visto anteriormente, sustenta parte da teoria 
das chamadas "pedagogias do aprender a aprender". O sistema de jogos de Spolin não traz o mundo para a sala de aula para ser estudado e experimentado através da linguagem teatral, pois estrutura-se em elementos privilegiados pelo drama burguês, como situações próximas ao cotidiano dos atores/jogadores, personagens verossímeis psicologicamente e espaços ficcionais próximos à realidade concreta, ainda que trabalhados como imaginários. Peter Szondi, em sua Teoria do drama burguês, observa que o fazer teatral europeu, no qual se inserem os jogos de Spolin, a partir do século XVIII, iniciou um processo de distanciamento das formas teatrais antigas ao, nas palavras de Sérgio de Carvalho, "abandonar pouco a pouco os coros, os apartes, o verso, [...] a relação direta com o público, as convenções e estilizações, em favor de uma concentração na intersubjetividade e no presente absoluto da ação" [CARVALHO apud SZONDI, 2004, p. 12]. Nesta perspectiva, o jogo dos atores em Spolin fica restrito a elementos do cotidiano e a discursos individualizantes, que não representam grupos, coletividades, classes sociais ou entidades míticas.

A crítica ao aprendizado da leitura restrito à produção interna do grupo também está presente no Jogo Dramático francês e no Drama britânico, o que compromete a possibilidade de contextualizações mais amplas, para além dos conteúdos formais dos alunos. O que se percebe é que as "pedagogias do jogo improvisacional", quando transportadas das ações socioculturais para a Educação Básica, realizam a pretendida abordagem triangular na aprendizagem do Teatro, como indicam os PCN-Arte. Porém, o que é problemático é a ênfase dada ao fazer como princípio pedagógico. O jogo improvisacional como operador do processo educativo faz com que essas modalidades pedagógicas submetam seus processos de fruição e contextualização aos conteúdos e formas dos próprios alunos, tornandoos reféns de seus próprios conhecimentos e negando-lhes o mundo como objeto de estudo. Neste sentido, torna-se importante a observação de Maria Lúcia Pupo ao se dirigir aos docentes universitários para afirmar que no processo de formação do Professor de Teatro o que se espera dos jovens profissionais não é certamente que eles apliquem jogos: "Formulações como essa reiteram uma visão redutora do nosso campo de trabalho, acarretando sem dúvida um desserviço à compreensão do nosso compromisso educacional" (PUPO, 2008, p. 34). 


\subsubsection{O jogo na educação estética e na educação poética}

A referência às sistematizações e metodologias de ensino e aprendizado da linguagem teatral que tem o jogo como operador aqui foram chamadas de "pedagogias do jogo improvisacional" e não simplesmente "pedagogias do jogo". O intuito foi o de reforçar o caráter do jogo de regras como ação física dos atuantes, pois, ainda que nessas metodologias exista uma plateia interna, esta não faz parte do jogo em si. Sua presença se deve, primeiro, para que o jogo seja jogado para alguém, ou seja, para que se estabeleça o outro para quem se realiza a ação teatral; e, em segundo lugar, para que os que assistem participem do processo de avaliação do jogo apresentado. A presença do espectador completaria, assim, a tríade teatral, agindo como o olhar externo ao jogo. A ênfase que se dá ao jogo nessas metodologias está em seu caráter físico, no jogo entre os atores, na improvisação cênica, no fazer, portanto, no jogo improvisacional. Como já foi dito, cada uma dessas pedagogias possui sua própria poética, seu modo próprio de fazer, que serve como referência única no processo de avaliação realizado pela plateia, por isso se avaliam a articulação das técnicas apropriadas a esse modo de fazer e os temas da improvisação. Os aspectos estéticos são submetidos ao modo de fazer, à poética, o que conduz a avaliação e, por conseguinte, o aprendizado através da recepção ao regime de identidade representativo ou poético, pois a tendência é a busca do jogo realizado dentro das regras poéticas estabelecidas, do "bem feito" de acordo com os parâmetros de cada modalidade pedagógica, do trabalho "dentro do foco", da verossimilhança, ou até mesmo da reprodução da realidade.

O jogo, no caso dessas pedagogias, é o jogo do movimento e da improvisação com regras, é um jogo prático e não o impulso lúdico analisado por Schiller, em sua $A$ Educação Estética do Homem: "O homem joga somente quando é homem no pleno sentido da palavra, e somente é homem pleno quando joga" (SCHILLER, 1995, p. 84, grifos do autor). Ainda que a frase seja bastante ampla quanto ao significado do jogo para o ser humano, Schiller está se referindo ao jogo que se desenvolve entre as capacidades racionais e sensíveis do homem, sem a mediação de regras e conceitos, e que se constituiria na verdadeira "liberdade humana", segundo Márcio Suzuki (1995, p. 156). Esse impulso lúdico origina-se na 
recepção de algo, que, necessariamente, é exterior ao sujeito: "O homem tem, primordialmente, de receber a matéria da atividade ou a realidade (que a inteligência suprema haure de si mesma), e ele a recebe, pela via da percepção, como algo existente fora dele, no espaço, ou como algo alternante nele, no tempo" (SCHILLER, 1995, p. 64, grifo do autor). Ou seja, é um jogo de aprendizado teórico, mas não passivo, pois mediado pelo que sofremos e ativado pelo que engendramos (a visão e a audição). Para Schiller,

Em seu primeiro estado físico, o homem capta o mundo sensível de maneira puramente passiva, apenas sente, sendo plenamente uno com ele, e justamente por ser o próprio homem apenas mundo, não há ainda mundo para ele. Somente quando, em estado estético, ele o coloca fora de si ou o contempla, sua personalidade se desloca dele, e um mundo the aparece porque deixou de ser uno com ele.

A contemplação (reflexão) é a primeira relação liberal do homem com o mundo que o circunda. Enquanto a voracidade agarra seu objeto de maneira imediata, a contemplação afasta o seu e faz dele a sua propriedade verdadeira e inalienável, à medida que o guarda da paixão. A necessidade natural, que o dominara sem divisão de poder no estado da mera sensação, libera o objeto na reflexão [...] [p. 129, grifo do autor].

Ao falar do jogo, Schiller refere-se, portanto, à contemplação estética e não à produção poética, pois para ele o artista do belo é um gênio, alguém que teria uma ligação com a divindade, com o absoluto. "Embora a poesia já tivesse dado um voo sublime, fê-lo apenas pelas asas do gênio, do qual sabemos ser vizinho da selvageria" (p. 59). A criação artística, para Schiller, está mais próxima à epifania, a um encontro do homem com Deus, do que ao jogo entre razão e sensibilidade. Não se quer com essas referências concordar com a perspectiva de Schiller sobre o artista do belo, porém, afirmar que o que esse filósofo chamou de impulso lúdico e ao decorrente jogo entre razão e sensibilidade se referia à apreensão estética e teórica do mundo e não à produção poética e prática.

$\mathrm{Na}$ escola que quer apresentar o mundo aos alunos, o desenvolvimento da capacidade de contemplação talvez seja fundamental para a formação do sujeito que, futuramente, agirá no mundo. Aqui se fala na capacidade de ver e ler o que está fora de si, mediado pela subjetividade, ou seja, não se fala em aprendizado, a capacidade de adaptação e acomodação do mundo no sujeito, mas em formação, o choque entre o mundo e o eu. 
Tão logo comece a fruir com o olho e o ver alcance para ele um valor autônomo, ele é já esteticamente livre, e o impulso lúdico se desenvolveu.

Assim que desperta, o impulso lúdico, que se apraz na aparência, será seguido pelo impulso mimético de criação, que trata a aparência como algo autônomo [p. 135].

O que se entende na leitura da obra de Schiller é que esse impulso mimético de criação se refere à reflexão, à criação pelo pensamento, e não, necessariamente, à ação física sobre a matéria, pois trata da aparência em si e não da sua produção. Dessa maneira, para este filósofo alemão, "a formação da sensibilidade é [...] a necessidade mais premente da época, não apenas porque ela vem a ser um meio de tornar o conhecimento melhorado eficaz para a vida, mas também porque desperta para a própria melhora do conhecimento" (p. 51).

Esse entendimento da recepção como jogo e como ato de produção de conhecimento, próprios ao papel do espectador, foi severamente atacado por diversos críticos, como observa Jacques Rancière em seu $O$ espectador emancipado (2012). Uns argumentando a partir da posição alienada do espectador diante de um mundo de aparências, as sombras na parede do Mito da Caverna platônico, sendo mantido distante da realidade encoberta e da verdade que estaria além dessas imagens que seriam somente simulacros. Outros argumentam que o espectador não age, mas, pelo contrário, fica imóvel e passivo em seu lugar. Ou seja, ser espectador seria um mal, pois ele estaria "separado ao mesmo tempo da capacidade de conhecer e do poder de agir" (RANCIÈRE, 2012, p. 8), o que faria do teatro, dependente que é desse olhar que seria o contrário do conhecer, uma coisa absolutamente ruim, como afirmava Platão. Em sendo assim, seria preciso criar um outro teatro,

um teatro sem espectadores; não um teatro diante de assentos vazios, mas um teatro no qual a relação óptica passiva inculcada pela própria palavra seja submetida a outra relação, a relação implicada em outra palavra, a palavra que designa o que é produzido em cena, o drama. Drama quer dizer ação. O teatro é o lugar onde uma ação é levada à sua consecução por corpos em movimento diante de corpos vivos por mobilizar [p. 9].

A conclusão de que seria preciso criar um novo teatro para o qual o papel do espectador deveria ser necessariamente revisto e requalificado irá desembocar, segundo Rancière, em duas grandes fórmulas: a de Bertolt Brecht, que vê o 
espectador alienado da verdade devido à empatia provocada pela projeção de imagens na "parede da caverna", e a de Antonin Artaud, para quem o espectador deveria sair de sua passividade física, "pois entre a vida e o teatro não haverá mais uma separação nítida" (ARTAUD, 1984, p. 158).

É neste ponto da recepção como leitura ativa do mundo que gostaria de me deter mais extensivamente com a finalidade de problematizar o papel secundário que a contemplação estética recebe nas "pedagogias do jogo improvisacional" quando diretamente transpostas para a Educação Básica. Novamente reafirmando que não se trata de advogar contra qualquer produção poética dentro da escola, mas propor que a leitura teatral não se submeta somente à produção dos alunos, mas seja ampliada e tenha como referência obras da tradição do teatro mundial, espelhadas tanto na arte do ator, como na do dramaturgo e do encenador.

\subsubsection{Recepção e leitura}

Recepção, fruição, apreensão, contemplação, leitura, todas são ações substantivadas pertinentes àqueles que ocupam o theatron, o lugar de onde se vê, se ouve, enfim, se assiste ao acontecimento cênico. Ali, distanciado do objeto representado e do objeto da representação, onde as paixões não o alcançam, pois a relação física não é táctil, mas visual e sonora, está o espectador. Nele acontece o impulso lúdico schilleriano resultante da ação recíproca entre o impulso sensível (passivo, receptivo) e o impulso formal (ativo, material, racional). "A beleza liga os estados opostos de sensação e pensamento, e ainda assim não há meio-termo entre os dois. A certeza daquilo é dada pela experiência; a disto, imediatamente pela razão" (SCHILLER, 1995, p. 95). Para Schiller, nessa passagem do estado passivo da sensibilidade para o ativo do pensamento e do querer está o estado intermediário da liberdade estética:

Se nos entregamos [...] à fruição da beleza autêntica, somos senhores, a um tempo e em grau idêntico, de nossas forças passivas e ativas, e com igual facilidade nos voltaremos para a seriedade e para o jogo, para o repouso e para o movimento, para a brandura e para a resistência, para o pensamento abstrato ou para a intuição [p. 114]. 
Partindo-se do pressuposto de que o objetivo da Educação Básica é a aprendizagem da linguagem teatral e não necessariamente a capacitação técnicoartística dos alunos, as formas de recepção da obra e o desenvolvimento da capacidade de leitura deveriam ter fundamental importância nos processos educativos em teatro. Sendo a fruição a função por excelência do espectador, os estudos desse papel dentro do fenômeno teatral podem nos indicar alguns caminhos pedagógicos no que concerne à educação do olhar e da escuta para a Educação Básica brasileira.

O pesquisador teatral francês Elie Konigson, especialista em História e Antropologia do teatro, ao voltar-se para o estudo do espaço teatral especialmente na Idade Média discorda da tese generalizada de que o teatro ocidental tenha origem em rituais litúrgicos, pois, segundo ele, ali não se encontram "nem atores nem espectadores, mas celebrantes e fiéis" (KONIGSON, 1996, p. 43). Em um artigo intitulado "Diviser pour jouer", que pode ser traduzido tanto como "Separar para representar" como "para jogar", Konigson defende que a separação entre palco e plateia, entre quem representa e quem assiste, é necessária para que o teatro se realize enquanto tal. Neste artigo ele afirma que o teatro na Europa é um dispositivo criado pela sociedade para exercer dentro da comunidade uma função dramática e não ritual, no qual os "atores" pertenciam ao corpo dirigente da cidade. Em sendo assim, "não se nasce espectador, mas torna-se" (p. 42), pois,

No momento em que o jogo se abre aos membros um pouco mais desfavorecidos da comunidade urbana, esses são relegados para fora do "perímetro de participação", sua exclusão fica marcada pelo afastamento e por vezes também por barreiras muito concretas. A área de jogo vista assim de longe, marca então o advento do espectador, quer dizer, daquele que assiste, vê ou antevê, mas não participa organicamente [p. 44].

Nesta divisão cabe ao espectador aceitar o pacto ficcional que o torna "mediador" entre o palco e a cidade exercendo uma "função dramática" denominada por Konigson de "guardião da realidade". Segundo Marie-Madeleine Mervant-Roux, esta metáfora associa a figura de um vigia de plantão a um mundo fora do teatro: "O espectador/guardião não 'protege' a cidade contra a ficção, mas a 'guarda' diante da ficção" (MERVANT-ROUX, 2010, grifos da autora), o que a faz afirmar que o espectador é "aquele que vem de fora". Dessa maneira, visto em sua função 
mediadora, o espectador é "tão eficaz precisamente porque ele é, por um lado, firmemente ancorado na realidade social, e por outro lado, capaz de perceber a poesia do palco" (MERVANT-ROUX, 2010).

Bertolt Brecht, em seu Teatro Épico-dialético, também defende essa necessária independência entre palco e plateia ao propor um distanciamento "científico" entre sujeito e objeto, espectador e cena, com uma diferenciação basilar: aquele que vê torna-se o alvo deste teatro épico para quem se direcionam os "ensinamentos" do palco, o que difere essa perspectiva daquela do espectador como "mediador" entre a ficção e a cidade, defendida por Konigson. A proposição brechtiana é uma das duas grandes fórmulas citadas por Rancière que pretendiam criar um novo teatro abolindo o papel do espectador como contemplador passivo do evento espetacular. Brecht pretendia desenvolver a capacidade de fruição do espectador e expressou essa intenção em um texto denominado Observação da Arte e Arte da Observação:

É uma opinião antiga e fundamental que uma obra de arte deve influenciar todas as pessoas, independentemente da idade, status ou educação [...] todas as pessoas podem entender e sentir prazer com uma obra de arte porque todas têm algo de artístico dentro de si [...] existem muitos artistas dispostos a não fazer arte apenas para um pequeno círculo de iniciados, que querem criar para o povo. Isso soa democrático, mas, na minha opinião, não é totalmente democrático. Democrático é transformar o pequeno círculo de iniciados em um grande círculo de iniciados. Pois a arte necessita de conhecimentos. A observação da arte só poderá levar a um prazer verdadeiro, se houver uma arte da observação. Assim como é verdade que em todo homem existe um artista, que o homem é o mais artista dentre todos os animais, também é certo que é um saber conquistado através do trabalho [BRECHT apud KOUDELA, 2010, p. 110, grifos do autor].

Brecht, mesmo reconhecendo que "em todo homem existe um artista", coloca esta característica em potência, como parte da natureza humana que não está nem será necessariamente desenvolvida no simples viver ou na simples contemplação estética. É preciso, portanto, desenvolvê-la potencializando a capacidade de fruição e apreensão do objeto artístico, pois, nas palavras de Schiller, "a realidade das coisas é obra das coisas; a aparência das coisas é obra do homem, e uma mente que aprecia a aparência já não se compraz com o que recebe, mas com o que faz" (SCHILLER, 1995, p. 134). Em Brecht, "a observação da arte só poderá levar a um prazer verdadeiro, se houver uma arte da observação", e como "a arte necessita de 
conhecimento", este saber só pode ser conquistado pelo trabalho. Não basta, portanto, sentar-se diante do palco e ser exposto ao fenômeno teatral, é preciso aprender a ler o que está sendo apresentado e entender os códigos da linguagem para estabelecer conexões e, assim, criar sentidos. Nas palavras de Rancière, 0 teatro épico brechtiano visa

arrancar o espectador ao embrutecimento do parvo fascinado pela aparência e conquistado pela empatia que o faz identificar-se com as personagens da cena. A este será mostrado, portanto, um espetáculo estranho, inabitual, um enigma cujo sentido ele precisa buscar. Assim, será obrigado a trocar a posição de espectador passivo pela de inquiridor ou experimentador científico que observa os fenômenos e procura suas causas [RANCIÈRE, 2012, p. 10].

Ou seja, para Brecht o ato de olhar por si só não acessa a verdade, pois o que o espetáculo mostra não é o mundo, mas seu simulacro. O impulso lúdico schilleriano, intermediário entre a sensibilidade e a razão, segundo Brecht, deveria ser acionado pela própria razão. Schiller, porém, não difere o estado de contemplação da ação do pensamento, pois, para ele, os dois seriam simultâneos:

A beleza, portanto, é objeto para nós, porque a reflexão é condição sob a qual temos uma sensação dela, mas é, ao mesmo tempo, estado de nosso sujeito, pois o sentimento é a condição sob a qual temos uma representação dela. Ela é, portanto, forma, pois que a contemplamos, mas é, ao mesmo tempo, vida, pois que a sentimos. Numa palavra: é, simultaneamente, nosso estado e nossa ação [SCHILLER, 1995, p. 131, grifos do autor].

Flávio Desgranges apoia-se, entre outros, no Teatro Épico-dialético de Bertolt Brecht, no flâneur de Walter Benjamin e na atitude dialógica diante da obra de arte proposta por Mikhail Bakhtin, para, assim, apresentar o espectador do teatro épico e formular uma possível pedagogia do espectador. Do teatro brechtiano vem a recusa ao processo de empatia por abandono, "o passivo deixar-se levar da plateia" (DESGRANGES, 2003, p. 129) ao que lhe é apresentado, para a assunção de uma atitude ativa e distanciada da cena. O espectador "científico" tem uma atitude crítica diante do espetáculo, "como a de uma pessoa que está fumando e observando algo ao mesmo tempo" (BRECHT, 1978, p. 27), refletindo sobre o que lhe é apresentado. De Benjamin, crítico da razão instrumental iluminista, Desgranges busca a ideia do flâneur, inspirada em Baudelaire, que em sua caminhada ao mesmo tempo distanciada e interessada pelas ruas da cidade, realiza a junção de fragmentos 
captados no transcorrer do tempo: "Como este sujeito das ruas, ele [o espectador do teatro épico] não se mantém parado, estático, vendo os fatos se sucederem, uns depois dos outros, mas passeia pela história, construindo-a" (DESGRANGES, 2003, p. 121), empreendendo uma atitude autoral, criativa. Tal atitude já era apontada como necessária por Schiller, em correspondência endereçada a Göethe, e citada por Brecht em seus Estudos sobre o teatro:

A ação dramática movimenta-se perante mim, enquanto sou eu quem se move em torno da ação épica, que está como que imóvel. No meu parecer, esta distinção é muito importante. Se é o acontecimento que se desenrola perante mim, fico rigorosamente muito acorrentado, pelos sentidos, ao presente, a minha fantasia perde toda e qualquer liberdade, uma inconstante intranquilidade surge e persiste em $\mathrm{mim}$, terei de me manter, sempre, diretamente preso ao objeto; a retrospecção e a meditação me são vedadas, porque uma força estranha me leva. Se for eu a moverme em torno do acontecimento, que não me pode escapar, ser-me-á possível caminhar sem acertar o meu passo por ele; poderei deter-me mais ou menos tempo, conforme as minhas necessidades subjetivas, poderei permitir-me retrocessos ou antecipações [SCHILLER apud BRECHT, 1978, p. 169].

E de Bakhtin, Desgranges traz a proposição de que "o fato artístico não está contido completamente no objeto, nem no psiquismo do criador, nem no do receptor, mas na relação desses três aspectos" (DESGRANGES, 2003, p. 123), o que faz com que a atitude do espectador diante do ato teatral seja um constante ir e vir, da obra e para si.

Desgranges defende que "o ato artístico solicita, pois, uma disponibilidade distinta do espectador. Disponibilidade esta que não parece evidente, e que não pode ser compreendida como um talento natural, mas sim como uma conquista cultural" (2012, p. 21). Se o espectador era visto como aquele que recebia a obra de arte, isto é, a obra estaria pronta e caberia ao espectador descobri-la, desvelá-la, desnudá-la, Desgranges representa uma perspectiva que, de certo modo, realiza uma inversão da olhadela ao afirmar que a obra, o ato artístico só se realiza e se completa na relação com o espectador. Se em Schiller a obra de arte era um elemento que provocava o impulso estético, agora a própria obra necessita deste impulso para se tornar arte. E, comungando com Brecht, Desgranges afirma que esse olhar não é dado, mas conquistado, pois pressupõe uma atitude autônoma do espectador diante da cena, selecionando e criando conexões e sentidos, tal qual o 
olhar do flâneur baudelaire/benjaminiano sobre as ruas de Paris no final do século XIX, ou como o co-autor bakhtiniano, ao mesmo tempo espectador e criador.

Essa "mudança de perspectiva" detectada por Desgranges pode ser encontrada nas práticas e nas reflexões do encenador russo Vsevolod Meierhold, que realizou diversos estudos sobre o espectador, a quem considerava o "quarto criador" do acontecimento teatral ao lado do dramaturgo, do encenador e do ator. Estudioso da obra de Meierhold, Brecht irá utilizar em seu teatro procedimentos como o estranhamento e a composição dialética da cena de forma a deixar espaços na obra para que o espectador possa criar. No quarto capítulo, o papel de Meierhold como encenador-pedagogo e sua perspectiva sobre o espectador serão analisados como modelos para a formação do Professor de Teatro.

Se Rancière detecta nas teorias e práticas de Bertolt Brecht uma das fórmulas para afastar do teatro o "mal" que seria ser espectador, a segunda viria das proposições de Antonin Artaud, para quem a distância reflexiva deveria ser abolida e o espectador deveria participar ativamente da ação.

O espectador deve ser retirado da posição de observador que examina calmamente o espetáculo que lhe é oferecido. Deve ser desapossado desse controle ilusório, arrastado para o círculo mágico da ação teatral, onde trocará o privilégio de observador racional pelo do ser na posse de suas energias vitais [RANCIÈRE, 2012, p. 10].

Desta maneira, se em Brecht o espectador deve ganhar distância crítica, em Artaud essa distância deve ser abolida, sendo que ambos desejam o mesmo: retirar o espectador de sua suposta passividade contemplativa. Segundo Rancière, em Brecht o teatro é visto tal qual uma assembleia e em Artaud como uma cerimônia, o que faz com que ambas as proposições tenham um mesmo objetivo, isto é, o teatro deve restaurar sua natureza comunitária. Rancière irá problematizar se a "natureza comunitária" do teatro exerce influência sobre a recepção do espectador, porém, para o momento, cabe observar o que o filósofo francês chama de "paradoxo do espectador", que seria o teatro retomando a seu favor os princípios da proibição platônica: o teatro não existe sem espectador e, ao mesmo tempo, deseja abolir esse papel para reafirmar-se como "bom" teatro (p. 12): 
O teatro se acusa de tornar os espectadores passivos e de trair assim sua essência de ação comunitária. Por conseguinte, outorga-se a missão de inverter seus efeitos e expiar suas culpas, devolvendo aos espectadores a posse de sua consciência e de sua atividade. A cena e a performance teatral tornam-se assim uma mediação evanescente entre o mal do espetáculo e a virtude do verdadeiro teatro. Elas se propõem ensinar a seus espectadores os meios de deixarem de ser espectadores e tornarem-se agentes de uma prática coletiva. Segundo o paradigma brechtiano, a mediação teatral os torna conscientes da situação social que lhe dá ensejo e desejosos de agir para transformá-la. Segundo a lógica de Artaud, ela os faz sair de sua posição de espectadores: em vez de ficarem em face de um espetáculo, são circundados pela performance, arrastados para o círculo da ação que lhes devolve a energia coletiva. Em ambos os casos, o teatro apresenta-se como uma mediação orientada para sua própria supressão [p. 12].

Rancière vê nestas duas proposições de criação de um novo teatro a mesma perspectiva embrutecedora, pois baseada na desigualdade entre os que estão no palco e aqueles da plateia; entre o mestre, aquele que tudo sabe, e o ignorante, aquele que deve saber. Caberia ao mestre "eliminar a distância entre seu saber e a ignorância do ignorante" (p. 13), porém essa distância é recriada a todo instante porque ao ignorante sempre faltará o "saber da ignorância, o conhecimento da distância exata que separa o saber da ignorância" (p. 14). O que Rancière defende é que não há dois tipos de inteligência separados por um abismo, mas sempre uma mesma inteligência em ação, "que traduz signos em outros signos e procede por comparações e figuras para comunicar suas aventuras intelectuais e compreender 0 que outra inteligência se esforça para comunicar-lhe" (p. 15), o que ele designa como um "trabalho poético de tradução".

Seja através do "impulso lúdico", de Schiller, seja como "guardião da realidade", em Konigson, seja por meio de um "saber conquistado pelo trabalho", em Brecht, ou de uma "conquista cultural", em Desgranges, ou ainda como um "trabalho poético de tradução", próprio à inteligência humana, em Rancière, o que todos têm em comum é a perspectiva de que ser espectador não é um papel passivo no teatro e que essa atitude deve ser potencializada. Ou, como escreveu Jorge Coli, "Não há escapatória: ver um quadro, ler um livro, é utilizar instrumentos culturais para apreendê-los" (COLI, 1995, p. 118). Nesse sentido, os integrantes da Cia. Teatro Balagan afirmam comungar das mesmas ideias expostas a eles pela educadora Madalena Freire: 
No mundo da educação formalizada - aquela que está fora da família - aprender não é algo fácil, tampouco natural. Não tem nada de espontâneo. Implica o exercício de agressividade do indivíduo com ele mesmo. Sentar, estudar, ir, voltar, escrever, ler. Impor. São processos onde está em voga uma agressividade sadia, que nada tem a ver com violência. A educação formal, não espontânea, lida com a resistência [BALAGAN, 2012b, p. 5].

Não se trata, pois, de algo dado como uma capacidade natural dos homens, mas de uma atitude diante de si e do mundo. "Aquele que almeja afirmar-se como indivíduo autônomo e criador deve travar um combate com suas próprias forças e potências" (p. 5).

A partir destas reflexões e considerando que um dos princípios dos PCN-Arte para criar as condições de fruição da arte e das mensagens estéticas é que estas sejam vistas como parte do exercício de cidadania, o aprendizado de leitura do espetáculo teatral deve, para nós, necessariamente, ser priorizado na Educação Básica brasileira. Como afirma Desgranges, a partir da citação de Guy Debord de que "a linguagem do espetáculo é constituída pelos signos da produção reinante",

tomar conhecimento dos mecanismos que envolvem uma encenação, desvendar e apreender a lógica da teatralidade significam conquistar instrumentos que viabilizem a reflexão acerca dos procedimentos utilizados em diferentes produções espetaculares. $O$ espectador instrumentalizado encontra-se em condições de decodificar os signos e questionar os significados produzidos, seja no palco, seja fora dele [DESGRANGES, 2003, p. 37].

Em um mundo em que produzir é a palavra de ordem, em que um lema contrário ao consumismo exacerbado como o "do it yourself" do movimento punk foi rapidamente incorporado pela publicidade capitalista para vender tênis, em que o "aprender fazendo" e a necessidade de sempre "aprender a aprender" estão disseminados nas faculdades de educação e licenciatura; no mundo do "quem sabe faz, quem não sabe aplaude", no qual todos devemos ser aplaudidos, pois todos devemos ser protagonistas, empreendedores de nossas vidas, porque já não há lugar para o coro quanto mais para o espectador; em um mundo em que muito se escreve nas redes sociais e pouco se lê, muito se fala nas salas de aula e pouco se ouve, talvez a educação estética seja fundamental para nos desacelerar e nos ajudar a ver e escutar o mundo em que vivemos. A educação estética pode ser aquele tempo em suspensão desejado por Masschelein e Simons e necessário para 
que a escola seja escola, pois não basta olhar, é preciso ver, não basta ouvir, é preciso escutar, não adianta ler, é preciso compreender.

\subsubsection{O espectador nas "pedagogias do jogo improvisacional”}

Para orientar os processos de leitura e contextualização, as "pedagogias do jogo improvisacional" enfatizam, como já foi dito, o fazer, na medida em que são parte decorrente do processo de avaliação do jogo improvisado para uma plateia composta pelos próprios participantes, que são também atuantes e espectadores das cenas criadas por eles mesmos. O que difere estas abordagens de ensino entre si e de outras são os elementos cênicos selecionados para a leitura e sua contextualização, oriundos de diferentes perspectivas políticas e estéticas, pois nos parece que a leitura da cena é realizada a partir de pressupostos poéticos e não necessariamente estéticos.

Os jogos teatrais propostos por Viola Spolin se organizam a partir da divisão do grupo de alunos entre jogadores (atuantes) e plateia (espectadores) e a posterior troca de funções. As experiências do fazer (escrever) e do assistir (ler) são complementares no processo de aprendizagem, que é finalizado somente após a avaliação (leitura) realizada por aqueles que assistiram ao jogo. Os elementos selecionados para esta leitura são aqueles relacionados à composição da cena: a situação ("o quê"), o espaço ficcional (“onde”), os personagens ("quem") e em como os atuantes realizaram a articulação destes três elementos em um discurso cênico verossímil ("foco"). Desta forma, a aprendizagem da linguagem teatral pelo espectador (via leitura) se dá através da análise do jogo entre os atores, tendo como parâmetros poético e estético o drama burguês, tal qual apresentado por Peter Szondi [2004].

O jogo dramático francês (jeu dramatique) proposto por Jean-Pierre Ryngaert possui a mesma estrutura de improvisações de Spolin: divisão entre palco e plateia, troca de funções e avaliação ao final dos jogos cênicos. O que os diferencia, entre outras coisas, são os elementos selecionados para a avaliação e quem a realiza, 
pois aqueles que atuam também são estimulados a expor as dificuldades enfrentadas durante o fazer das improvisações (o ato de "escrever"). Os elementos selecionados para a leitura dos espectadores são aqueles relacionados à arte do ator em diálogo com a composição da cena, elementos plástico-espaciais e temporais (sonoridades, movimentações e gestualidades). Ryngaert amplia, em relação a Spolin, a aprendizagem da linguagem teatral centrada no ator incorporando-o à encenação através de uma leitura polifônica da cena. Para Ryngaert, saber ler teatro é saber decodificar seus elementos estéticos constitutivos e colocá-los em relação ao jogo dos atores, criando possíveis diálogos e fricções.

A divisão entre palco e plateia também é utilizada em algumas práticas pedagógicas do Teatro do Oprimido (TO) de Augusto Boal. Nas apresentações de Teatro Imagem e Teatro Fórum inicialmente a divisão entre quem atua e quem assiste é preservada para que se realize por parte dos espectadores a leitura da cena. A troca de funções, ao contrário de Spolin e Ryngaert, não é obrigatória, ainda que desejada e estimulada. Após realizar a leitura da cena do "mundo como está" (representada por atores), o espectador de TO é convidado a intervir, seja através de sugestões para alterações da dramaturgia apresentada, seja através da entrada no palco como ator e/ou diretor cênico e, desta forma, recriar a cena de maneira que ela passe a representar o "mundo como poderia ser". Em seguida, para que o teatro se realize como um "ensaio da revolução", os espectadores são convidados a criar as condições para que o mundo se transforme através das "cenas de transição".

Boal vê no teatro um potente instrumento de análise da realidade social, sob a perspectiva da luta de classes, do confronto entre opressores e oprimidos. A leitura da cena, desta forma, privilegia a organização espacial e os gestos produzidos pelos atuantes que revelem as relações de poder e de opressão entre os homens. Não se trata, portanto, de uma leitura em que os elementos estéticos tenham significados em si ou em relação à composição da cena, mas de uma leitura em que o sentido político das escolhas e sua maior ou menor fidelidade à realidade social fortaleçam os instrumentos de análise, escolhidos a priori, e da ação política que, espera-se, se seguirá para além da ficção.

A aprendizagem da linguagem teatral através do Teatro do Oprimido objetiva transformar seus participantes em atores no mundo, portanto trata-se de uma 
alfabetização em que a leitura da cena (e do mundo) tem como objetivo capacitar a escrita (ação) no mundo). A leitura é usada como instrumento para a escrita, tanto que Boal criou um novo termo para os participantes de suas práticas políticopedagógicas, o espect-ator.

Se Spolin e Ryngaert privilegiam, no processo de aprendizagem da linguagem teatral por parte do espectador, a leitura de elementos estéticos da cena, seja daqueles que se referem à atuação, objetivando a reprodução do mundo como ele se apresenta aos nossos sentidos (Spolin), seja dos que se referem à composição, objetivando a criação de um olhar artístico e potencialmente criativo sobre o mundo (Ryngaert), Boal opta por uma leitura em que a estética é vista sob uma perspectiva político-ideológica.

Do mesmo modo, Bertolt Brecht ansiava por um espectador "especialista", como os admiradores de práticas esportivas, integrado ao grande círculo de iniciados, para seu Teatro Épico-dialético e, em sua metodologia de alfabetização na linguagem teatral, irá propor a mais radical forma de leitura da cena: a eliminação da plateia. Perspectivas aparentemente contraditórias sobre o papel do espectador se não levarmos em consideração que Brecht trabalhava sempre a partir das condições políticas que lhes eram apresentadas. Durante a maior parte de sua vida artística ele atuou como "escrevinhador de peças", produzindo textos e encenações para o teatro profissional. Suas episches Schaustück (peças épicas de espetáculo) eram, para ele, "soluções de emergência transitória", porque quando teve a oportunidade de trabalhar com grupos de teatro de amadores e operários, coros de trabalhadores e grupos de escolares, formulou e colocou em prática uma pedagogia teatral inovadora, as peças didáticas (Lerstück).

No jogo teatral com a peça didática, Brecht tornará a presença da plateia dispensável, pois o objetivo de sua pedagogia é o de ensinar e colocar à disposição dos atuantes os meios de produção teatral. A abolição da plateia não era, necessariamente, a abolição do papel do espectador para transformá-lo em atuante dentro de um ritual, como queria Artaud. O espectador da peça didática está em cena, porém mantém aquela distância crítica entre realidade e ficção, escrevendo e lendo simultaneamente. Nas palavras de Walter Benjamin, "cada espectador é ao mesmo tempo observador e atuante" (BENJAMIN apud KOUDELA, 2010, p. 36). 
Aqui está a origem do que Boal batizaria, quarenta anos depois, de espect-ator. Tal proposição crítica por parte do atuante também integra a teoria do Teatro Épicodialético, na qual Brecht se refere aos efeitos de estranhamento na arte dramática chinesa através de uma medida técnica do ator: "o artista é um espectador de si próprio" (BRECHT, 1978, p. 56). Para capacitar o atuante nos dois papéis ao mesmo tempo, Brecht irá colocar em prática dois instrumentos didáticos: o citado efeito de estranhamento (Verfremdungeffeckt ou V-effekt) e o gestus, e um procedimento didático, a troca de papeis entre os atuantes de forma que todos possam jogar todos os papéis da fábula. O exercício de construção e composição cênica com estes instrumentos e essa didática exige dos participantes a leitura de seus próprios gestos (como se fosse uma "citação"), dos gestos dos demais jogadores e das relações espaciais criadas e recriadas durante as improvisações para que o $V$ effeckt atinja seus objetivos de "estranhamento" do que é apresentado como familiar. Exige uma leitura rigorosa das "relações do homem com o homem", onde os gestos físicos expressem as motivações interiores das personagens e as formas de poder e opressão entre semelhantes.

Tanto na perspectiva distanciada do espectador do Teatro Épico-dialético, como no experimento físico do gestus e do estranhamento nas peças didáticas, a alfabetização na linguagem teatral para Brecht faz parte de um programa políticoestético em que o espectador de hoje será o transformador do mundo amanhã. Por isso sua proposta de aprendizagem da linguagem teatral tem como objetivo propiciar aos oprimidos a tomada dos meios de produção, para que, ao ler o mundo "como ele está", possam transformá-lo em "como ele poderia ser". Ainda que aqui caiba a crítica realizada ao TO no que se refere à leitura da cena (e do mundo) estar a serviço da escrita (ação no mundo), há que se ressaltar que na teoria da peça didática existe a preocupação com que as transformações do indivíduo e da sociedade sejam intrínsecas e interdependentes. O jogo realizado sobre uma fábula definida como modelo de ação, distanciada no tempo e no espaço da realidade concreta do atuante, já é, em si, uma maneira de aliená-lo com um intuito pedagógico, colocando-o em uma posição "científica" na qual é necessário criar as conexões possíveis entre a cena e a vida real. Ao propor a leitura do próprio gestus como instrumento de aprendizagem, Brecht aponta para a necessidade da leitura 
como ato de transformação inclusive e necessariamente individual e não somente como instrumento para a ação. A leitura já é em si um ato e não está colocada somente como pré-ato, pré-ação ou ensaio.

Em se tratando da aprendizagem na linguagem teatral como componente curricular obrigatório na Educação Básica do Brasil, o problemático nessas modalidades que querem impor um "novo mundo" às novas gerações, privando-as da possibilidade de criarem seu próprio mundo novo, está também em sua lógica de "imediatez ética", segundo o termo cunhado por Rancière. O problema não estaria na mensagem política transmitida, mas nos dispositivos utilizados. Ao se questionar um modelo pedagógico baseado no regime representativo ou poético e na eficácia da arte como portadora de mensagens e modelos de comportamento, o que pressupõe "um continuum sensível entre a produção de imagens, de gestos ou palavras e a percepção de uma situação que empenhe pensamentos, sentimentos e ações dos espectadores" (RANCIÈRE, 2012, p. 54), propõe-se a abolição da representatividade.

Substitui a duvidosa pretensão da representação a corrigir os costumes e os pensamentos por um modelo arquiético. Arquiético no sentido de que os pensamentos já não são objetos de lições dadas por corpos ou imagens representados, mas estão diretamente encarnados em costumes, em modos de ser da comunidade [p. 56].

Retoma-se o paradigma da arte presente no pensamento platônico e no regime ético das imagens que opõe à mentira da mimese teatral a boa mimese, da "arte que não separa a cena da performance artística e a da vida coletiva" (p. 55), opondo à "eficácia da arte" a "imediatez ética", cujo modelo é o da arte que suprime a si mesma.

Este é o mesmo dispositivo de outra metodologia de Teatro e Educação que vem ganhando espaço nas práticas pedagógicas brasileiras, o Drama britânico, que, assim como a peça didática brechtiana, prescinde da presença de uma plateia para a realização da alfabetização na linguagem teatral. Tal perspectiva pedagógica se explica pela herança vinda dos jogos dramáticos (dramatic play) e do "aprender fazendo", porém, ao opor-se ao seu "deixar fazer", o Drama propõe um processo de avaliação através da leitura da cena improvisada. O que distingue essa leitura realizada pelos próprios participantes do jogo improvisacional de modalidades como 
o TO e a Peça Didática é que a ênfase está na investigação sobre o tema que está sendo estudado e não em seus significados político-ideológicos.

\subsubsection{Fora do jogo: o espectador como alteridade}

Marie-Madeleine Mervant-Roux, contrariamente ao atual "contexto artístico em que a encenação comporta, cada vez mais frequentemente, um condicionamento do público - ou mesmo sua inclusão no jogo cênico" (MERVANT-ROUX, 2008, p. 1286), defende o papel do espectador como "aquele que vem de fora" do teatro, estranho e estrangeiro ao evento teatral, incumbido de exercer uma "atividade mediúnica", a mediação entre a obra e o mundo. Seu papel efetivo como espectador e não como participante ("co-ator") deve ser resguardado.

Mervant-Roux cita Elie Konigson ao defender a necessária independência dos três elementos do dispositivo teatral de base para a garantia da função dramática no interior da sociedade: uma cena, um ator e um espectador que aceita o pacto inicial ficcional. A inclusão do espectador como participante da cena romperia a fronteira entre o jogo e o olhar, interrompendo a função de alteridade exercida pelo espectador. Konigson estabelece como necessária a divisão entre palco e plateia para que a representação possa atingir toda sua potencialidade (KONIGSON, 1996), pois quando o espectador é visto como participante com uma função direta na ação, a prioridade é dada "ao evento, a imediaticidade, ao corpo expressivo, ao invés da atividade mental e de lembrança, à suspenção da reação" (MERVANT-ROUX, 2010). Ou, nas palavras de Adorno e Horkheimer, "o pensamento se torna ilusório sempre que tenta renegar sua função separadora, de distanciamento e objetivação" (ADORNO e HORKHEIMER, 1985, p. 43).

Talvez essa necessidade de interagir com a cena, de atuar e de escrever, faça parte do processo que Walter Benjamin detectava há quase cem anos como a perda progressiva que o homem ocidental (europeu) apresenta da "faculdade de intercambiar experiências" (BENJMIN, 1994, p. 198). Pela própria pobreza de experiências que o mundo vem proporcionando, pois "as ações da experiência estão 
em baixa, e tudo indica que continuarão caindo até que seu valor desapareça de todo" (p. 198), assistimos a perda de sensibilidade, de atenção e de escuta que a ausência de experiências sensíveis provoca. Num mundo cada vez mais voltado para o indivíduo, para as realizações pessoais conquistadas através do desenvolvimento da capacidade de competitividade, o outro torna-se um empecilho, um obstáculo a ser superado. A necessidade de entrar no jogo, de fazer parte do fenômeno teatral, pode ser reflexa, de um lado, da possibilidade de participar de algo cuja experiência pode vir a ser mais rica que a sua própria vida, e de outro lado, devido à impaciência para assistir ao espetáculo, fruir a obra. Talvez essa necessidade de interagir, de pegar a coisa, seja a própria necessidade do consumidor em se sentir dono e senhor da ação, o que faz com que o ato de assistir se torne pobre em experiência devido ao embotamento dos sentidos decorrente da necessidade de posse e consumo. A questão a ser formulada é se tal mudança na função do espectador, transformando-o em participante na cena, poderia se tornar um empecilho para a leitura do espetáculo.

A conceituação do espectador como aquele que vem de fora problematiza as práticas das "pedagogias do jogo improvisacional" no que concerne à fruição, pois em geral nestas metodologias o aprendizado da linguagem teatral acontece no interior da própria oficina teatral, a partir da leitura de elementos específicos da cena produzida pelos próprios participantes, e que, portanto, não vêm de fora, não são estranhos à produção cênica. Segundo Mervant-Roux, pode-se

definir o teatro como a associação de dois grandes mediadores, um no palco, outro no auditório, colaborando juntos em uma atividade mítica que transcende cada um deles. O espectador, em particular, não flutua entre dois mundos. Ele é um meio tão eficaz precisamente porque ele é, por um lado, firmemente ancorado na realidade social, e por outro lado, capaz de perceber a poesia do palco (MERVANT-ROUX, 2010, grifo da autora).

Os três elementos do dispositivo teatral de base garantiriam a existência de uma terceira forma de eficácia da arte, que Ranciére chama de "eficácia estética", pois é própria ao regime estético da arte. Trata-se da "suspensão de qualquer relação determinável entre a intenção do artista, a forma sensível apresentada num lugar de arte, o olhar de um espectador e um estado de comunidade" (RANCIÈRE, 2012, p. 57). Como se vê, Rancière estrutura seu pensamento na necessária 
separação dos elementos de base do teatro, como Konigson e Mervant-Roux também o fazem, porém opõe-se a influência sobre a recepção do espectador exercida pela "natureza comunitária" do teatro. Para ele, o poder comum dos espectadores não estaria relacionado ao seu pertencimento a um corpo coletivo (uma assembleia para Brecht, uma cerimônia para Artaud) ou a alguma forma específica de interatividade, mas ao "poder que cada um tem de traduzir à sua maneira o que percebe" (p. 20). Esse é o poder comum quando o ponto de partida é o da igualdade das inteligências, a "capacidade que torna qualquer um igual a qualquer outro" (p. 21).

É nesse poder de associar e dissociar que reside a emancipação do espectador, ou seja, a emancipação de cada um de nós como espectador. Ser espectador não é a condição passiva que deveríamos converter em atividade. É nossa situação normal. Aprendemos e ensinamos, agimos e conhecemos também como espectadores que relacionam a todo instante o que veem ao que viram e disseram, fizeram e sonharam. Não há forma privilegiada como não há ponto de partida privilegiado. [...] Não temos de transformar os espectadores em atores e os ignorantes em intelectuais. Temos de reconhecer o saber em ação no ignorante e a atividade própria do espectador. Todo espectador já é ator de sua história; todo ator, todo homem de ação, espectador da mesma história [p. 21].

Não cabe a este trabalho analisar os caminhos do teatro contemporâneo e se a entrada do espectador no jogo cênico comprometeria a própria existência do teatro tal qual o concebemos, isto é, baseado no dispositivo ator-cena-espectador. Mas nos cabe problematizar pedagogias teatrais em que os participantes tomam para si as duas figuras mediadoras citadas por Mervant-Roux, a do ator e a do espectador, e fazem as ligações entre palco e mundo sem o distanciamento necessário para qualquer forma de leitura. As "pedagogias do jogo improvisacional", ao enfatizarem o fazer e colocarem a fruição a serviço desta produção, propiciam uma leitura redutora do teatro como linguagem e como conhecimento do mundo pois refém do fazer dos próprios participantes. O mundo colocado sobre a mesa para ser estudado e experimentado pelos alunos da Educação Básica torna-se um mundo "em comum", já conhecido, e não um mundo estranho a ser decifrado. 


\subsection{Teatro ou linguagem teatral?}

Algumas questões foram levantadas no corpo deste trabalho e não foram respondidas. Não acredito que se possa dar respostas definitivas a elas, mas se pode pensar em algumas "soluções transitórias". E, mesmo transitórias, não serão, necessariamente, as mais acertadas, porém merecem ser, no mínimo, colocadas aqui como conclusão das reflexões realizadas.

O primeiro capítulo foi finalizado com a questão em torno da curricularização ou não das artes, visto que, em a Escola Básica brasileira vir a ser ofertada em horário integral, o contraturno seria o mais indicado para as atividades artísticas. O oferecimento do aprendizado das artes de maneira mais livre e optativa, sem o peso de notas e avaliações, sem a necessidade de seguir a organização curricular, com tempo de aula mais extenso e espaços mais adequados, sem dúvida nenhuma iria propiciar uma experiência artística aos alunos muito mais rica e aprofundada. É o que se percebe em atividades socioculturais, por exemplo. Mas, retirar a Arte do currículo é reconhecer que esta não é uma forma de conhecimento do mundo e sobre o mundo que mereça ser compartilhada entre todos. Seria privar as novas gerações da riqueza da produção em arte da humanidade, do acesso à diversidade de linguagens artísticas e sugerir que esse conhecimento é um algo a mais, uma espécie de luxo que não tem a ver com as necessidades básicas humanas e que não pode ser visto como uma forma de melhorar a própria humanidade.

Com a Arte curricularizada, a questão a ser feita é em torno de como inseri-la efetivamente na escola, reconhecendo-a como área de conhecimento e legitimando seus modos pedagógicos, conforme foi problematizado no segundo capítulo. A dificuldade arraigada na comunidade escolar em geral, e pode-se dizer que na sociedade brasileira como um todo, é reconhecer na arte uma forma de conhecimento do mundo tão legítima quanto a ciência e a filosofia. Para que isto ocorra é necessário que a Arte receba o mesmo tratamento das demais áreas do conhecimento, espaços de aula adequados, materiais didáticos atualizados, quantidade de aulas em que se possa desenvolver um processo de ensino e aprendizagem aprofundado, efetiva participação no projeto pedagógico das escolas 
e professores formados na área. Porém, se realmente acredita-se que a escola é o grande projeto democrático da humanidade, o local em que todos são tratados como iguais, com os mesmos direitos de acesso ao mundo, é preciso por parte dos arte educadores que se entenda esse sentido. Não é possível exigir que a escola se modifique para receber as artes e seus modos pedagógicos. É a Arte que deve se adequar à escola e não o contrário. Não se neguem os atritos e os choques existentes, não se neguem as experiências transformadoras e emancipatórias que a arte pode propiciar à educação escolar, mas é preciso reconhecer que o projeto é democrático, antes de tudo, por apresentar 0 mundo às novas gerações indistintamente, e propiciar-lhes tempo livre para que estudem e experimentem esse mundo, do qual a arte é parte e não o todo.

Os modos pedagógicos para que a Arte possa ser inserida na Educação Básica estão bem delineados nos próprios PCN: reconhecer a Arte em suas linguagens artísticas. Talvez o sonho dos arte educadores e dos artistas é ver a arte realizando sua função questionadora e desestabilizadora dos estratos, emoldurando o caos, nas palavras de Deleuze e Guattari [1992]. Porém, talvez a escola não suporte estas fissuras e linhas de fuga, pois a ela cabe a função de apresentar os estratos às novas gerações para que estas, sim, façam esse trabalho. Querer que a Arte realize sua função desestabilizadora na escola é ter que reconstruir a escola sempre, a cada fratura. Uma instituição fragilizada, vítima da ingerência dos mais fortes poderes da sociedade, refém de uma sociedade produtivista e pautada na competitividade, dificilmente teria condições e forças para se reestruturar a cada fissura criada. Ver a Arte como linguagem talvez seja uma forma de domar sua rebeldia sem retirar-lhe, porém, sua potência de transformação futura da realidade. Estudar seus modos de fazer, suas técnicas, suas estéticas e seus modos de ler o mundo podem instrumentalizar as futuras gerações para que, elas sim, e se quiserem, façam da Arte seu jeito de ser e de ver o mundo.

Ver a Arte sob a perspectiva de suas linguagens demanda a formação de professores especializados. Pelo que se apresentou neste capítulo, a formação do Professor de Teatro exige um grau mínimo de especialização na linguagem e em seus modos pedagógicos. Não é possível esperar que um Professor de Arte formado em Música transite com desenvoltura por todos os temas relacionados ao teatro aqui 
apresentados. E ainda dê conta da linguagem da Dança e das Artes Visuais. Poderíamos retomar a antiga formação polivalente em Educação Artística, melhorando-a e ampliando-a, porém seria recair em um generalismo sobre a Arte que, no máximo, e contando com a honestidade dos profissionais de ensino, geraria um aprendizado de cultura geral especializada nas manifestações artísticas. Seria como esperar que o professor de Biologia ministrasse aulas de Química e de Física como se fossem sua área de especialização. Por outro lado, não reconhecer a dificuldade que o país encontra na formação de profissionais aptos nas linguagens presentes nos PCN-Arte e nos problemas que as escolas enfrentam para a contratação de quatro profissionais especialistas para ministrar somente uma disciplina é continuar a agir com leviandade em relação à inserção da Arte na Educação Básica brasileira. Se, por um lado, precisamos exigir a contratação de profissionais especialistas nas linguagens artísticas, também é preciso propiciar uma formação mais ampla e generalista dentro de cada linguagem nas licenciaturas do país. O Professor de Teatro não pode ficar restrito ao seu mundo, falando somente através de sua linguagem. É preciso dialogar com as demais linguagens e com conhecimentos que a Arte como um todo pode propiciar às novas gerações, ainda que se mantenha o Teatro como linguagem operadora. A volta do professor polivalente talvez não seja uma boa solução, mas também não o é a manutenção de professores de Arte que só sabem escrever e ler através de suas linguagens.

\subsubsection{Pedagogia do Teatro e emancipação: fricções}

Como realizar a abordagem pedagógica em cada linguagem artística dentro da Educação Básica e como parte do projeto democrático da escola talvez seja a questão seguinte a ser problematizada. A abordagem triangular proposta por Ana Mae Barbosa parece contemplar os dois atos necessários para que a arte seja reconhecida como tal: o fazer e o fruir, a poética e a estética; aliado a um terceiro, necessário para que a escola possa abrir o mundo para os alunos, a contextualização. O que se problematizou acima foi o acento, a ênfase que cada um 
desses três atos deve ter de acordo com as modalidades pedagógicas apropriadas a cada linguagem, em especial, àquelas referentes à linguagem teatral.

A opção pela aprendizagem da linguagem e não da arte expressa nos PCNArte pode orientar as problematizações em torno do ensino do teatro dentro da escola. Quando se fala em ensinar ou aprender teatro o que o senso comum entende é que se irá para o palco e se aprenderá como montar um espetáculo. É o paradigma da espetacularização sobre o qual foram abordados alguns aspectos. Porém, pode-se também afirmar que, a partir da década de 1980, decorrente do oferecimento de cursos e oficinas teatrais pelo país através de projetos socioculturais, aprender teatro incorporou o sentido que as "pedagogias do jogo improvisacional" Ihe dão: jogar, improvisar, experimentar, sem necessariamente concluir o processo pedagógico em um espetáculo teatral. $\mathrm{O}$ produto do teatro também passou a ser entendido como uma cena improvisada, a apresentação pública de um jogo teatral, um processo de discussão política conduzido pelo fazer teatral. Seja nas "pedagogias do espetáculo", seja na dos jogos improvisacionais, o senso comum entende a aprendizagem de teatro como "fazer teatro".

Ao optar-se pelo ensino não propriamente da arte do teatro mas da linguagem teatral a perspectiva educativa necessariamente se modifica. Não basta somente aprender a escrever teatro com desenvoltura, colocando a leitura do ato cênico em uma condição meramente instrumental para o fazer. É preciso desenvolver as capacidades de leitura da obra teatral, o que significa que é necessário ampliar o acesso aos objetos de leitura em direção à multiplicidade de teatros feitos pelo mundo. É preciso pensar com mais afinco pedagogias que abram o mundo para os alunos e que lhes possibilitem uma espécie de proficiência na linguagem, uma pedagogia da recepção e do espectador. Wolfgang Maar afirma que, para Adorno, "é preciso romper com a educação enquanto mera apropriação de instrumental técnico e receituário para a eficiência, insistindo no aprendizado aberto à elaboração da história e ao contato com o outro não-idêntico, o diferenciado" (MAAR, 1995, p. 27). Daí a pertinência da colocação de Mervant-Roux do espectador como "aquele que vem de fora" e de sua afirmação de que o atual "enobrecimento da figura do espectador, que se tornou uma verdadeira 'espect-ator', foi paradoxalmente 
esvaziada: por ser tão completamente integrada no teatro, perdeu a sua realidade externa de espectador" (MERVANT-ROUX, 2010, grifo meu).

O ato de recepção é um ato pessoal e intransferível e a leitura de uma obra teatral pode passar por outros conhecimentos não necessariamente concernentes à fruição estética. As experiências de cada indivíduo não são intercambiáveis e a forma como ele as articulará diante da obra de arte não se dará necessariamente na dimensão lógico-racional. Como observa Flavio Desgranges, "o sentido de uma cena não se constitui como um dado prévio, estabelecido antes da leitura, algo pronto, fixo, atribuído desde sempre pelo artista, mas algo que se realiza na própria relação do espectador com o texto cênico" (DESGRANGES, 2012, p. 17). Philippe Ripoll diz que "a questão do espectador não deve se restringir aos problemas de recepção ou a fatores exclusivamente semióticos ou sociológicos, mas deve, antes, ser aberto à sua dimensão profundamente simbólica (ou seja, criativa)" (RIPOLL apud MERVANT-ROUX, 2010).

Para Rancière, as oposições entre o olhar e o saber, entre aparência e realidade e entre atividade e passividade definem uma "divisão do sensível, uma distribuição apriorística das posições e das capacidades e incapacidades vinculadas a essas posições" (RANCIĖRE, 2012, p. 16), e que estas seriam, portanto, categorias da desigualdade.

A emancipação, por sua vez, começa quando se questiona a oposição entre olhar e agir, quando se compreende que as evidências que assim estruturam as relações do dizer, do ver e do fazer pertencem à estrutura da dominação e da sujeição. Começa quando se compreende que olhar é também uma ação que confirma ou transforma essa distribuição das posições. O espectador também age, tal como o aluno ou o intelectual. Ele observa, seleciona, compara, interpreta. [...] Assim, são ao mesmo tempo espectadores distantes e intérpretes ativos do espetáculo que lhes é proposto [p. 17].

Uma escola voltada a processos educativos emancipadores deveria considerar o trabalho poético de tradução de seus alunos como o cerne de toda aprendizagem. O que sempre está em jogo é uma mesma inteligência que traduz signos. No caso da Educação Básica, é preciso associar o sentido da fruição e da contemplação estética ao desenvolvimento da capacidade de leitura da arte e do mundo. Limitar os procedimentos de leitura às produções dos alunos é restringir o 
universo do teatro às expressões dos próprios alunos. Neste sentido, Jorge Coli afirma que para se aprender arte é preciso frequentar arte, ver, escutar, analisar, e que esta frequentação capacitaria o espectador a realizar a construção de seu conhecimento, constituindo-se em um sujeito emancipado. Porém, a frequentação ao teatro não é algo simples de se realizar no Brasil. A maioria das cidades do país não possui sequer uma sala de espetáculos e o deslocamento de alunos até às salas existentes nem sempre é possível devido à falta de transporte apropriado. Em geral, as saídas de alunos para atividades externas à escola podem ser contabilizadas em uma ou duas vezes durante todo o ano letivo. A ida de grupos teatrais para dentro das escolas poderia suprir essa demanda, porém sabe-se que a estrutura arquitetônica da maioria de nossas escolas não possui condições mínimas para receber esses artistas. E mesmo a existência desses coletivos em todo o território nacional ainda é incipiente para suprir essa demanda.

Uma possibilidade seria a de alargar o entendimento do que é teatro tendo como parâmetro seus elementos essenciais, a cena, o ator e o espectador, sem se prender a visões redutoras que veem a arte teatral somente naquelas manifestações que acontecem dentro das paredes do edifício teatral ou naquelas que, mesmo acontecendo nas ruas, se autodenominam teatro por conter os elementos dessa tríade essencial. No contexto brasileiro e, especificamente, alagoano seria interessante ver o teatro nas formas espetaculares que a arte de tradição popular produz sem recair, porém, em categorizações vindas da antropologia, da sociologia e do folclore, e até mesmo das academias teatrais, como a etnocenologia. Esse teatro de tradição popular - que muitas vezes não é reconhecido nem se reconhece como tal - está disseminado por todo o território do país através das manifestações mais variadas possíveis, como as cavalhadas, os bois, os desfiles de escolas de samba, maracatus, reisados, marujadas, só para citar algumas. Nele estão os três elementos da tríade teatral, os atores/atuantes/brincantes, a cena em suas mais variadas formas de espacialização e os espectadores; estão presentes as poéticas e as técnicas; e estão presentes os modos de transmissão da tradição (as pedagogias).

A legitimação das manifestações espetaculares da tradição popular brasileira como teatro na Educação Básica brasileira permitiria, talvez, uma mudança de 
perspectiva em relação às formas de produção da arte. Dar-lhes o status de "arte que se estuda na escola" seria reconhecer valores estéticos e poéticos antes somente reconhecidos em outros teatros tidos como canônicos do patrimônio cultural da humanidade. Seria uma forma de retirar-lhes o estigma de produções vistas como "menores", "artesanais" e/ou "folclóricas", adjetivos utilizados para desmerecer e desqualificar o trabalho manual e a práxis poética de artistas vindos das classes sociais mais pobres da população brasileira. Essa mudança de olhar sobre essa arte feita pelo povo é um ato na direção de uma educação emancipadora, pois, nas palavras de Rancière,

Apoderar-se da perspectiva é já definir uma presença num espaço que não é o do "trabalho que não espera". É romper a divisão entre os que estão submetidos à necessidade do trabalho dos braços e os que dispõem da liberdade do olhar. [...] Essa apropriação estética [..] define a constituição de outro corpo que já não está "adaptado" à divisão policial de lugares, funções e competências sociais. [...] Pois para os dominados a questão nunca foi tomar consciência dos mecanismos de dominação, mas criar um corpo votado a outra coisa, que não a dominação. [...] O que produz essas paixões, essas subversões na disposição dos corpos não é esta ou aquela obra de arte, mas as formas de olhar correspondentes às formas novas de exposição das obras, às formas de sua existência separada [RANCIÈRE, 2012, p. 61].

O olhar que contempla essas encenações do teatro popular brasileiro pode realizar a leitura estética dos elementos presentes na cena, como a arte do ator e da dramaturgia. O espetáculo, o que se dá a ver, é o ponto de interseção entre o atuante e o espectador, entre aquele que escreve e aquele que lê.

Na lógica da emancipação há sempre entre o mestre ignorante e o aprendiz emancipado uma terceira coisa - um livro ou qualquer outro escrito - estranha a ambos e à qual eles podem recorrer para comprovar juntos o que o aluno viu, o que disse e o que pensa a respeito [p. 19].

Neste sentido, a encenação seria o "livro" que se coloca sobre a mesa para que os alunos possam estudar, experimentar e praticar a linguagem teatral. Para Guénoun, "o espectador de teatro existe como encenador. O encenador é exatamente um espectador que se coloca em posição de ser o espectador. 0 encenador é esta consciência subjetiva, que pretende ocupar o lugar da assembleia teatral, por condensação" (GUÉNOUN, 2004, p. 118, grifos do autor). Talvez na função do encenador a separação entre olhar e saber, entre passividade e atividade, 
tidas por Rancière como "categorias da desigualdade", seja completamente ignorada, pois, para Guénoun, "o encenador é o único espectador cujo olhar se empenha numa prática - uma ação" (p. 128, grifo do autor) e que pode, assim, "entrelaçar invenção e transmissão" (p. 162), poética e pedagogia operadas pelo olhar. 


\title{
4 \\ CONCLUSÃO EM FORMA DE PROPOSIÇÕES
}

\author{
um bom poema \\ leva anos \\ cinco jogando bola, \\ mais cinco estudando sânscrito, \\ seis carregando pedra, \\ nove namorando a vizinha, \\ sete levando porrada, \\ quatro andando sozinho, \\ três mudando de cidade, \\ dez trocando de assunto, \\ uma eternidade, eu e você, \\ caminhando junto
}

Paulo Leminski 
O que se segue não é um bom poema, nem poema é. São ações no mundo. Tentativas de intervir na realidade e de transformá-la. Limitadas, mas que, quando formuladas, carregavam aquele desejo do ideal possível para o momento. Trata-se de ações que se pretendem significativas para o ensino e a aprendizagem escolar da linguagem teatral e estão apresentadas em um sentido que vai do macro ao mínimo, como uma forma de aproximação ao que era o objeto de pesquisa inicial desta tese.

A primeira ação que ainda se encontra a meio caminho entre a proposição e o embate com a realidade foi realizada durante o processo de construção dos Referenciais Curriculares para a Educação Básica da Rede de Ensino Estadual de Alagoas, na qual atuei como consultor para a área de Arte. Surgiu da necessidade de se formular uma proposta viável, "uma solução de emergência transitória" (STEINWEG apud KOUDELA, 2010, p. 5), e que pudesse oferecer outras perspectivas para o ensino de Arte nas escolas públicas alagoanas. Várias das questões apontadas nos capítulos anteriores desta tese como problemáticas surgiram durante o processo de construção desses Referenciais, no momento de embate entre minha aversão inicial ao ensino escolarizado do Teatro e a necessidade de compreender e conhecer a Educação Básica no estado de Alagoas. Por isso, hoje, dois anos após a realização deste trabalho, talvez algumas das proposições fossem diferentes, pois o enfoque mudou um pouco neste tempo e a perspectiva se deslocou, aproximando-se mais das necessidades da escola do que das artes. Mas, dentro do contexto histórico, econômico, social e cultural no qual está inserido o trabalho, posso afirmar que a visão geral na qual ela foi construída continua a mesma e, por isso, vale ser exposta e problematizada.

A segunda ação analisada refere-se à construção do Projeto Pedagógico do Curso (PPC) de Teatro Licenciatura da UFAL e está sendo colocada em prática, ainda que reconheça ser muito cedo para se aferir sobre o seu alcance no processo formativo dos estudantes e possíveis desdobramentos na Educação Básica, deste estado. O projeto é fruto de um olhar para o futuro, com o desejo de que este se realize através do diálogo entre a licenciatura em Teatro e as manifestações artísticas da tradição popular alagoana, e vem carregado de ideais que se pretendem duradouros para o ensino da linguagem teatral, seja para a Educação 
Básica, seja como ação sociocultural. Voltado para a formação do Professor de Teatro em Alagoas, é resultado de tudo o que foi pesquisado e estudado para a realização desta tese e sua presença aqui é motivada pela necessidade em se problematizar o ensino do Teatro a partir do contexto cultural em que está inserido.

A terceira proposição se refere ao objeto de pesquisa inicial desta tese: a encenação como prática pedagógica para o ensino do teatro. Não é fruto de uma necessidade, mas da paixão. É minha pequena pedra muiraquitã "roubada" pelo Gigante Piaimã há três anos quando troquei de assunto para esta tese, me afastando um pouco de seus estudos teóricos, mas que continua pendurada em meu pescoço durante minhas práticas pedagógicas. Talvez o que se queria como uma tese de doutoramento seja o que se apresenta aqui, através de algumas linhas em forma de conclusão e como proposição para a formação dos futuros professores de Teatro de Alagoas. Uma paixão que talvez não tenha sido suficiente para este trabalho acadêmico, mas que ainda é o que me move na vida. Até a próxima tempestade ou que um peixe a engula definitivamente.

Colocar as três proposições aqui, como transitórias e em processo, é, também, assumir o caráter inconcluso deste trabalho, que se quer mais como uma problematização do ensino do Teatro na Educação Básica do que como uma resposta final para a formação de professores de Teatro no Brasil.

\subsection{O componente Arte na educação pública de Alagoas}

Entre o final do ano de 2013 e o início de 2014, participei do processo de construção dos Referenciais Curriculares para a Educação Básica de Alagoas, junto à Secretaria de Estado da Educação e do Esporte (SEE). O relato e as conjecturas realizadas a partir desse trabalho que tratam da desvalorização da Arte em relação às demais áreas do conhecimento escolar no sistema público de ensino alagoano se encontram no primeiro capítulo desta tese ${ }^{27}$. Aqui serão analisadas proposições que

\footnotetext{
${ }^{27} \mathrm{O}$ relato encontra-se nas páginas 55 e 56, e as conjecturas nas páginas seguintes, que tratam dos desencontros entre a legislação educacional e a escola.
} 
procuram enfrentar duas questões levantadas no início da pesquisa: a persistência do caráter polivalente que permeia a contratação do professor de Arte sem se levar em consideração as especificidades das linguagens artísticas e a ausência de conteúdos conceituais seriados que integrem uma Base Nacional Curricular Comum (BNCC).

Registre-se em relação à persistência da polivalência no ensino da Arte na educação pública de Alagoas que fui o único consultor contratado para esta área de conhecimento e que, portanto, articulei as propostas de organização curricular para as quatro linguagens artísticas que compõem os componentes curriculares da disciplina. Mesmo observando inicialmente o equívoco da contratação única, percebi durante o processo que, naquele contexto, a participação de um consultor que se dispusesse a exercitar uma perspectiva mais global parecia ser mais necessária para estabelecer algum diálogo com os professores que participavam do processo do que alguém que defendesse as especificidades de cada linguagem artística. Assim, ainda que constatando a carência de visões específicas para cada linguagem durante o trabalho, estas foram minimizadas através da participação dos próprios professores de Arte da rede pública alagoana.

Algumas determinações da SEE são fundamentais para se compreender o contexto no qual se deu a construção dos Referenciais. A principal, e inevitável, é que deveriam ser respeitadas todas as determinações presentes na LDB nํ 9.394/96 (BRASIL, 1996) e seguidas as Diretrizes e os Parâmetros Curriculares Nacionais (BRASIL, 1997a, 1997b, 1998, 2000a, 2000b). A segunda determinação refere-se à defesa dos "pilares" da educação escolar propostos pela UNESCO para o século XXI, "o aprender a conhecer, o aprender a fazer, o aprender a conviver e o aprender a ser [...] que sustentam política e pedagogicamente também estes Referenciais." (ALAGOAS, 2014, p. 174).

Por fim, a terceira determinação refere-se à autoria do documento, que deveria ser elaborado de forma coletiva junto aos Técnicos Pedagógicos da SEE incorporando sugestões e intervenções dos professores da rede pública estadual de Alagoas. Porém, o único contato pessoal da consultoria de Arte com os professores foi realizado durante o III Encontro para a Construção dos Referenciais Curriculares, em fins de 2013, o que pode ser uma das explicações para as poucas e tímidas 
propostas vindas dos educadores. Ainda que o encontro tenha sido curto, os três dias foram fundamentais para se compreender o nível de formação da maioria dos profissionais, os enfoques mais gerais e usuais em sala de aula e entender-se, ainda que superficialmente, o que seria e o que não seria viável para a implementação dos futuros Referenciais Curriculares. A grande preocupação era a de não repetir o que me parecem ser alguns dos problemas presentes nos PCN-Arte: a idealização do ensino de Arte sem que se apresentem formas para operar as mudanças necessárias e, assim, inviabilizando parte de sua aplicação em sala de aula.

\subsubsection{Linguagem operadora e organização dos conteúdos curriculares}

A preocupação com a viabilidade de implantação dos referenciais de Arte na sala de aula nos levou a aceitar a polivalência como uma daquelas "soluções de emergência transitórias", ainda que reforçássemos a não concordância em relação a esta situação. Diante do paradoxo em que se encontra o ensino de Arte no Brasil, no qual a Educação Básica demanda professores com uma formação generalista que o Ensino Superior, especializado nas linguagens artísticas, não supre, e do entendimento de que a SEE iria manter esse caráter generalista na contratação de professores de Arte para a rede estadual de ensino, fez-se a seguinte observação na Caracterização de Área presente no documento final:

Reafirmamos a necessidade da presença de professores especialistas e espaço curricular para as quatro linguagens, visto que cada uma se diferencia da outra em sua forma de operar sobre o mundo. Porém, por se tratar de iniciativa inviável dentro da atual estrutura educacional do país, a proposta que o professor de Arte trabalhe a partir da linguagem específica na qual realizou sua formação superior, desenvolvendo atividades que incluam, sempre que possível, as outras linguagens artísticas [p. 116 $]^{28}$.

Trata-se de solução semelhante à apresentada por Edilene B. da Silva (2013), em seu TCC de Teatro Licenciatura da UFAL, e comentada no primeiro capítulo desta tese, ou seja, trabalhar a partir de uma espécie de interdisciplinaridade entre

\footnotetext{
${ }^{28}$ Para facilitar a consulta, os trechos referentes ao componente Arte encontram-se no Anexo $\mathrm{C}$ deste trabalho.
} 
as artes, privilegiando como operador no processo de ensino e aprendizagem a linguagem na qual o Professor de Arte se formou. Em se tratando de um documento oficial, fizemos questão de afirmar a "necessidade da presença de professores especialistas", mesmo entendendo que o contexto alagoano ainda demanda professores polivalentes.

A opção por uma linguagem operadora, que sugere esta espécie de "polivalência através da interdisciplinaridade", determinou a indicação de conteúdos conceituais e habilidades específicos para cada uma das quatro linguagens artísticas, privilegiando, porém, os conteúdos gerais de Arte. A preocupação foi a de evitar visões extremamente parciais do significado das artes restritas a uma única linguagem. Assim, por exemplo, no $6^{\circ}$ ano indica-se a abordagem de alguns conceitos de arte e suas diversas linguagens, enquanto no $7^{\circ}$ ano, voltado às expressões artísticas alagoanas, os conteúdos conceituais se referem ao estudo da Arte Sacra e das manifestações da tradição popular no estado. Pretendia-se com estas indicações gerais que alunos de uma escola que tenham o mesmo professor de Arte habilitado, por exemplo, em Música, por todo o Ensino Fundamental II, completem seus estudos na Educação Básica capacitados a, pelo menos, compreender as formas de pensar o mundo e atuar nele das demais linguagens a partir de elementos gerais e comuns a todas.

Diante da recente aprovação do Projeto de Lei nำ 7.032/2010, pelo Congresso Nacional que torna obrigatório o ensino de Música, Dança, Teatro e Artes Visuais como componentes curriculares da disciplina Arte aliada à persistência na não contratação de professores especializados pela SEE, a necessidade de abordagens que contemplem essas quatro linguagens artísticas se torna ainda mais acentuada. As indicações realizadas nos Referenciais Curriculares alagoanos talvez possam enfrentar esta questão de forma a respeitar os direitos de aprendizagem dos estudantes e as especializações dos professores, ainda que entendamos que esta seja uma solução paliativa e que de forma alguma contempla as especificidades do ensino da Arte na Educação Básica.

Outra preocupação foi a de criar uma estratégia que enfrentasse a ausência de uma sequência curricular seriada para o componente Arte. Se para os demais componentes da área de Linguagens (Português, Língua Estrangeira e Educação 
Física), na qual Arte se insere nos Referenciais alagoanos, há uma tradição curricular que atua como parâmetro para a sequência seriada, o ensino escolarizado das artes não possui esse lastro histórico. Percebemos que esta estratégia poderia ser formulada em resposta à exigência da própria SEE, a de se apresentar os conteúdos seriados a partir da perspectiva de direitos de aprendizagem, organizados em atitudes, competências, eixos de aprendizagem, habilidades e conteúdos conceituais.

Os Referenciais Curriculares alagoanos consideram os direitos de aprendizagem dos estudantes como todos os saberes de diferentes tipos a serem garantidos aos estudantes; atitudes como tendências ou predisposições para atuar de certo modo, de acordo com determinados valores; competências como capacidades amplas; habilidades como capacidades específicas, que contribuem para o desenvolvimento das competências; conteúdos conceituais como os conceitos e fatos a serem ensinados para favorecer o desenvolvimento das habilidades e competências previstas a cada ano de escolaridade; e eixos como organizadores gerais do componente curricular (p. 72).

Esta perspectiva determinada pela SEE para os Referenciais Curriculares alagoanos os insere no que se chamou, no segundo capítulo deste trabalho, de "pedagogias do aprender a aprender". Sendo esta a condição dada, não caberia aos consultores criticar ou propor outras perspectivas possíveis para o ensino escolar alagoano, mas discutir como construir os referenciais a partir dela. Com esta forma de organização curricular pré-determinada, pensamos em formular uma estratégia para o componente Arte que evitasse as situações denunciadas anteriormente aqui, ou seja, a dependência na qual os estudantes acabam sendo submetidos a conteúdos selecionados exclusivamente pelos professores da disciplina. A seleção de conteúdos e sua organização seriada deixadas sob a responsabilidade da direção pedagógica da escola, como indicam os PCN-Arte (BRASIL, 1998), acabam por ser determinadas, na prática, unicamente pelo professor da área no caso das escolas públicas alagoanas. Diante de situações como, por exemplo, a necessidade de mudança de escola por parte do estudante ou mesmo a transferência do próprio professor da disciplina, pode-se gerar graves lacunas na formação dos alunos ao final da Educação Básica, seja na compreensão das artes como forma de pensar e 
agir no mundo, seja no reconhecimento da arte como patrimônio cultural. Se, por um lado, os conteúdos conceituais seriados podem se caracterizar como uma maneira de tolher a suposta liberdade de ensino dos professores de Arte, por outro, também podem se constituir como um instrumento de formação social, uma maneira de aproximar os pais e a comunidade do sentido desses conteúdos.

A estratégia sugerida foi a de acrescentar um elemento norteador exclusivo para cada série letiva ao eixo de ensino e aprendizagem indicado pelos PCN-Arte (BRASIL, 1997a), isto é, a abordagem triangular proposta por Ana Mae Barbosa. Este elemento organizaria o fazer, o apreciar e o contextualizar de forma que se pudesse inserir uma sequência curricular que orientasse o trabalho dos professores, o estudo dos alunos e criasse um sentido geral para a aprendizagem.

A escolha de um elemento norteador também procura evitar que o ensino de Arte seja visto somente como sinônimo de história da arte, tendência ampla entre os professores da disciplina, como já foi mostrado no primeiro capítulo desta tese. Em muitos casos esta perspectiva é vista como a única forma para orientar a sequência curricular seriada da área, podendo reduzir os conteúdos conceituais a movimentos, escolas e estilos artísticos, e realizando a contextualização das artes somente a partir de causas e consequências histórico-sociais ou a partir de aspectos formalistas de tradição e ruptura, como se só se pudesse compreender e apreciar uma obra do Barroco se antes se tiver estudado o Renascimento. Não se quer com isso descartar a abordagem histórica, porém é necessário lembrar que esta não é a única forma de se contextualizar a presença da arte como produção cultural. 0 intuito é o de se evitar uma visão cronológica na qual os movimentos e tendências são alinhados um após outro sem uma contextualização histórica, social, política e antropológica, como muitas vezes acontece no ensino da Literatura escolar.

A sequência seriada de conteúdos curriculares baseada em uma organização cronológica travestida como história da arte parecia-nos, assim, retirar a potência do pensamento artístico, conferindo às obras de arte uma aura que faz com que elas atinjam a "ineficiência de um clássico". A obra de arte ao ser vista somente na perspectiva de patrimônio cultural, tornada clássica, intocada, acrítica, canonizada, esteriliza-se, perde sua potência como moldura do caos. Segundo Hannah Arendt, 
o fio da continuidade histórica foi o primeiro substituto para a tradição; por seu intermédio, a avassaladora massa dos valores mais divergentes, dos mais contraditórios pensamentos e das mais conflitantes autoridades, todos os quais haviam sido, de algum modo, capazes de funcionar conjuntamente, foram reduzidos a um desenvolvimento unilinear e dialeticamente coerente, na verdade, não para repudiar a tradição como tal, mas a autoridade de todas as tradições [ARENDT, 2011, p. 55].

O estudo das artes na escola através do "fio da continuidade histórica" nos induz a pensar que um aluno do sexto ano é capaz de compreender uma pintura das cavernas de Lascaux mas é incapaz de apreciar uma serigrafia de Andy Warhol. É como se disséssemos aos alunos: você só entenderá a arte contemporânea, isto é, a arte de seu tempo, no terceiro ano do Ensino Médio.

Diante de outras possibilidades de contextualização pensamos se não seria o caso de propor formas distintas de abordagem ao longo da vida escolar do estudante. A divisão qualitativa presente na introdução dos Referenciais alagoanos entre o Ensino Fundamental e o Ensino Médio orientou-nos na escolha desses diferentes norteadores:

Os anos finais (6ำ ao $9^{\circ}$ ano) [do Ensino Fundamental] são considerados como período de consolidação e sistematização dos conceitos científicos previstos para esta etapa da educação básica, utilizando as diferentes linguagens como meio para representação, comunicação e principalmente interação nos diversos contextos sociais [ALAGOAS, 2014, p. 33].

Já o Ensino Médio "tem como objetivos a consolidação e o aprofundamento dos conhecimentos adquiridos no Ensino Fundamental" (p. 35). As competências indicadas por esses Referenciais vão ganhando em complexidade ano a ano, variando quantitativamente, sendo que nesta passagem do Ensino Fundamental para o Médio propõe-se um salto qualitativo. No Ensino Fundamental as competências concentram-se na aquisição crítica dos instrumentos de análise produzidos pela humanidade, para que no Ensino Médio o estudante coloque estes instrumentos culturais em relação e, consequentemente, possa ter competência para produzir conhecimento. Propusemos, assim, norteadores qualitativamente diferentes para cada etapa do ensino escolar, sendo que a cada série no Ensino Fundamental II haveria variações quantitativas e no Ensino Médio, perspectivas críticas diferenciadas. 


\subsubsection{Norteador espacial para o Ensino Fundamental II}

Nos anos finais do Ensino Fundamental propusemos que a organização seriada do currículo fosse espacial e não temporal, fazendo com que as relações corporais de distâncias e proximidades atuassem como operadores na aprendizagem através do fazer, do apreciar e do contextualizar. A ideia era a de se partir do concreto, do próximo, das relações físicas do estudante com a obra de arte, até se chegar às obras distanciadas no tempo e no espaço, pois, segundo os Referenciais Curriculares alagoanos,

as crianças de 11 (onze) e 12 (doze) anos, pré-adolescentes, apresentam a linguagem e as capacidades psíquicas e cognitivas já bem desenvolvidas, demonstrando capacidade de analisar detalhadamente um objeto, fato ou situação, levantar hipóteses, organizar as ideias a partir de uma determinada lógica, estabelecer princípios, interrelações e argumentos coerentes. [...] De modo geral, são observadas as primeiras transformações biológicas e emocionais características do período da puberdade, por isso recomendam-se atividades de interação social, pois é a partir delas que as crianças podem reconhecer o outro, respeitar as diferenças, construir os princípios de justiça e cooperação social, além de combater todas as formas de preconceitos e de discriminação social. Nesse sentido, esses aspectos não podem deixar de ser observados no desenvolvimento do currículo [p. 34].

Através do norteador espacial os estudantes dessa faixa etária (correspondente ao terceiro ciclo do Ensino Fundamental) estudariam a Arte a partir de sua família, de sua casa, de sua rua, de seu bairro, até chegar, ao final do sexto ano, às formas artísticas presentes em sua cidade; e no sétimo ano estudariam a Arte produzida no estado de Alagoas. A proximidade às manifestações artísticas auxiliaria na escolha de atividades com o intuito da "interação social" desejada no documento para essa faixa etária, propiciando um entendimento ampliado do que é arte, de seu sentido na vida das pessoas, suas funções sociais, culturais, políticas, psicológicas e religiosas, e, portanto, atuando no "combate [a] todas as formas de preconceito e de discriminação social". Propiciaria também um entendimento de arte como parte da vida das pessoas, como manifestação de todo ser humano, seja ele um artista profissional ou não, garantindo o direito de acesso à produção artística a todo cidadão. As manifestações artísticas quando entendidas como universais e 
inerentes aos homens e mulheres, estejam elas próximas ou distantes de nós - a música de infância do avô e o filme assistido na televisão, as cores e os materiais utilizados pelos artesãos da cidade e o palácio do governador, as brincadeiras de rua e o DVD da cantora preferida, o sol desenhado com tijolo na rua e os quadros dos museus -, estão carregadas de sentidos, de sentimento e de sonho humano. São expressões da igualdade de inteligência entre os homens.

Partindo-se do espaço concreto que cerca o estudante do sexto ano, sua casa e a família que a habita, o aluno poderá compreender como as manifestações artísticas fazem parte de seu cotidiano e de seu modo de se relacionar com o mundo. Podem se tornar material de estudo e experimentação as músicas que se cantam e que se ouvem, as cores e formas presentes nos objetos e nas paredes, a organização espacial e a composição dos elementos, os gestos e narrativas familiares, as roupas que se vestem, as danças que se dançam e que se assistem etc. O espaço de análise vai se ampliando conforme a apreensão da realidade vai acontecendo, da casa para a rua, dali para o bairro, para os espaços comunitários (escola, igreja, clube, lazer), até se chegar à cidade. Espaços que o próprio corpo do aluno é capaz de explorar, de sentir e de pensar sobre e em relação a eles.

O estudo das manifestações artísticas a partir das relações espaciais de proximidade e distanciamento, e não necessariamente compartimentadas dentro das diversas linguagens, procura enfrentar o paradigma aludido no primeiro capítulo que associa a Arte à pintura e às artes plásticas em geral, conforme denunciam Marques e Brazil (2014, p. 22) ${ }^{29}$. A partir deste norteador organizamos o currículo do sexto ano tendo como atitudes esperadas dos estudantes a "valorização da arte como forma de pensamento" (ALAGOAS, 2014, p. 117), presente em todos os direitos de aprendizagem no que se refere ao componente Arte dentro dos Referenciais alagoanos, e o "uso das linguagens artísticas como ferramentas de leitura, contextualização e transformação de si e de sua comunidade" (p. 47).

A partir do sétimo ano este espaço concreto vai se tornando um pouco mais abstrato, submetido a construções históricas coletivas como as divisões políticoterritoriais do país, fazendo com que a contextualização espacial abarque o estado

\footnotetext{
${ }^{29}$ O paradigma das artes plásticas entendidas como conteúdo único da disciplina Arte é analisado nas páginas 47-52 deste trabalho.
} 
de Alagoas e sua produção artística. O aluno poderá explorar este espaço através de suas memórias de viagens e da memória de seus familiares; de estudos etnográficos e históricos; da apreciação de obras seja fisicamente, por meio de estudos de campo, seja virtualmente, através de livros e das tecnologias da comunicação. Os estudos de campo podem ser realizados em cidades próximas e por meio de visitas a aparelhos públicos exclusivos da capital alagoana (museus, teatros, espaços expositivos), do estudo das características, similaridades e diferenças das regiões geográficas (região metropolitana, litoral sul, litoral norte, agreste e sertão), chegando-se aos limites do estado de Alagoas.

A compreensão da arte amplia-se do domínio da comunidade e da cidade para o estado, inserindo-se também o entendimento do povo alagoano, sua história, suas etnias formadoras e incorporando uma habilidade desenvolvida no sexto ano, a capacidade crítica de discernir os meios de produção e difusão característicos da tradição popular, da indústria cultural e da chamada arte erudita.

A organização curricular, assim, amplia-se não só geograficamente, mas nas atitudes esperadas, do "uso das linguagens artísticas como ferramentas de leitura, contextualização e transformação de si e de sua comunidade" (p. 117), para o "uso das linguagens artísticas como ferramentas de [...] transformação da realidade" ( $p$. 118).

Nesta organização espacial que parte do próximo para se chegar ao universal, o oitavo ano se dedicaria à arte brasileira e o nono ano, à arte no mundo, sempre seguindo as orientações dos Referenciais alagoanos para cada faixa etária:

Os adolescentes de 13 (treze) e 14 (quatorze) anos, assim como na fase anterior, também são marcados pelas transformações biológicas e pela formulação de hipóteses acerca de sua identidade, autoimagem, afetividade e sexualidade, apresentando uma acentuada capacidade de observação e criticidade, ou seja, há mais dúvidas do que certezas a respeito de si mesmo, das relações com o outro e com o mundo. $\mathrm{Na}$ abordagem curricular, é necessário adotar metodologias de trabalho diferenciadas que favoreçam o desenvolvimento de sua capacidade de análise, associação, generalização e síntese na proposição de ideias, na resolução de situações-problema e na interação social, tais como: a pesquisa, o trabalho em grupo, a música, o teatro e outras formas de produção e manifestação do conhecimento [p. 34]. 
Neste quarto e último ciclo do Ensino Fundamental através da ampliação geográfica da área de estudo procuramos intensificar a "capacidade de análise, associação, generalização e síntese" a partir de atividades de pesquisa e trabalho em grupo. As habilidades e competências desenvolvidas no ciclo anterior serão aqui necessárias para operar em níveis cada vez mais abstratos, como os conceitos de identidade nacional e herança cultural ao lado de multiplicidade, universalidade e diferenças culturais.

Seguindo a proposta de ampliação dos horizontes, no sentido do próximo para o distante, o oitavo ano iniciará os estudos da produção artística brasileira a partir dos estados fronteiriços a Alagoas, das manifestações artísticas nordestinas, até se chegar à compreensão da multiplicidade cultural do povo brasileiro. A ampliação do campo de estudo pressupõe o desenvolvimento das competências e habilidades que vinham sendo desenvolvidas nos anos anteriores que compreendem o discernimento da composição étnica do povo brasileiro e das formas artísticas vindas das tradições populares, da indústria cultural e da chamada arte erudita.

No nono ano o sentido iria das fronteiras nacionais à produção mundial, da América do Sul a todo continente americano, passando pela América Latina; daqui para a África, Europa, Oriente Médio, extremo Oriente, Polinésia e Oceania. As competências desenvolvidas nos anos anteriores serão fundamentais para a compreensão da multiplicidade cultural do mundo, da criação de cânones e do conceito de patrimônio da humanidade, que se constituirão nos objetos de estudos. Espera-se chegar a uma compreensão da importância das artes ao longo da história da humanidade e de suas transformações ao longo dos tempos; das contribuições que cada etnia, povo e civilização trouxeram para se criar um sentido alargado, múltiplo e diferenciado do que são as artes, do que é o mundo e o ser humano; do entendimento crítico das influências que os meios de produção, apreciação e contextualização podem ter sobre as manifestações artísticas e sobre as ações do homem no mundo.

A partir desta contextualização espacial do ensino de Arte espera-se que o estudante alagoano possa compreender o sentido das artes em sua vida e na vida dos homens; as relações que se estabelecem e que também se transformam entre 
as obras de arte e o mundo com o passar do tempo e com as diferenças espaciais; o conceito de arte, de gosto, de belo e feio, de sublime e grotesco; o sentido de composição; as diferenças das linguagens artísticas; os valores de troca das obras (utilitários e simbólicos); as diferenças de mediação (artes da tradição popular, da chamada cultura erudita e da indústria cultural); as diferentes formas de manifestação e de inserção na comunidade de uma mesma linguagem artística (cotidianas, artesanais, simbólicas, religiosas, mercantilizadas), dentre outras possibilidades.

A organização curricular espacial parece-nos ampla o bastante para abarcar diversas áreas do conhecimento escolar e restrita o suficiente para que o aluno compreenda a potência transformadora das manifestações artísticas nelas próprias.

\subsubsection{Norteador crítico-cultural para o Ensino Médio}

Analisando-se os documentos oficiais para a educação escolar, percebe-se uma diferenciação qualitativa expressa na própria divisão entre ensinos Médio e Fundamental, tanto em nível nacional como nas especificidades da rede estadual de ensino de Alagoas. A diferenciação qualitativa pode ser exemplificada na organização dos conteúdos curriculares indicada pelos PCN (BRASIL, 1997a) e nos objetivos educacionais presentes nos Referenciais Curriculares alagoanos (ALAGOAS, 2014) para cada uma dessas etapas da Educação Básica. Se no Ensino Fundamental os PCN dividem o conhecimento escolar em oito áreas e os Referenciais Curriculares alagoanos propõem uma espécie de instrumentalização das linguagens, utilizadas "como meio para representação, comunicação e principalmente interação nos diversos contextos sociais" (ALAGOAS, 2014, p. 33), no Ensino Médio os PCN, partindo do entendimento que os conhecimentos estão cada vez mais imbricados, dividem o conhecimento escolar em três grandes áreas e os Referenciais Curriculares alagoanos propõem "como objetivos a consolidação e o aprofundamento dos conhecimentos adquiridos no Ensino Fundamental" (p. 35), através do desenvolvimento de competências e habilidades em relacionar esses conteúdos. 
Essa etapa possibilita aos jovens continuar os estudos, o preparo básico para o trabalho e para a cidadania e seu aprimoramento como ser humano integral proporcionando a formação ética, a autonomia intelectual, a criticidade e ainda a compreensão dos fundamentos científico-tecnológicos, articulando teoria e prática [p. 35].

A articulação teoria e prática parece-nos ser o principal alvo da abordagem triangular de Ana Mae Barbosa por este motivo o fazer, o apreciar e o contextualizar continuam a integrar nosso eixo para o ensino e a aprendizagem em Arte. Porém, se o eixo seria o mesmo do Ensino Fundamental, parecia-nos necessário organizar os direitos de aprendizagem dos estudantes do Ensino Médio de uma forma diferente, que procurasse sublinhar essa diferença qualitativa entre os dois níveis de ensino. $O$ norteador espacial proposto para o Ensino Fundamental talvez já não fosse o mais indicado diante dos objetivos a serem atingidos no último nível da Educação Básica alagoana expostos acima. Se nos Referenciais Curriculares alagoanos para o Ensino Fundamental deseja-se a aquisição de competências de análise, no Ensino Médio estas competências continuarão a ser desenvolvidas através de conhecimentos escolares mais específicos e especializados. O que era chamado de Ciências passa a ser dividido em Biologia, Química e Física; os Estudos Sociais, já divididos em História e Geografia, ganham outros operadores, a Filosofia e a Sociologia. Ainda que agrupados em apenas três grandes áreas, os conhecimentos vão se tornando cada vez mais divididos e especializados podendo se fragmentar e perder suas capacidades de comunicação entre si. O estudante corre o risco de eleger somente uma forma de ler a realidade e se fechar em preconceitos epistemológicos. A especialização dos conhecimentos pode se voltar contra os próprios conhecimentos transformados em mercadoria e fetiche, perdendo, assim, sua potência transformadora. Era preciso pensar uma maneira de colocar os componentes curriculares em relação uns com os outros sem perder as especificidades das linguagens artísticas como campos de conhecimento. Procurar formas de conexão, contato e diálogo entre as áreas para se organizar uma sequência curricular seriada para Arte.

As formas de operar das duas mais recentes disciplinas das Ciências Humanas presentes no Ensino Médio, Filosofia e Sociologia, se apresentaram como uma possibilidade para realizar a interdisciplinaridade necessária. Trata-se de duas 
áreas de conhecimento social e do homem que operam a partir de relações e conexões com outros campos de estudos escolares, como a História e a Geografia, criando diferentes conceitos e outras maneiras de ler e interpretar o mundo. Percebemos que, assim como elas, poderíamos propor uma abordagem diferente da temporal e da espacial que tivesse como norteadora a análise crítica e cultural das manifestações artísticas através das inter-relações entre tempo e espaço. Elegemos, assim, três perspectivas críticas diferenciadas para cada um dos três anos do Ensino Médio:

a proposta de estudo, para os alunos do $1^{\circ}$ ano, é o próprio sujeito criador, isto é, a dimensão subjetiva e expressiva do ato artístico, que envolve os aspectos psicológicos e filosóficos da criação e apreciação artística. Para os alunos do $2^{\circ}$ ano, a questão é a sociedade na qual a produção se insere, isto é, a dimensão objetiva e comunicativa do ato artístico, envolvendo os aspectos políticos e sociológicos em que esta produção está inserida. E, finalmente, para os alunos do $3^{\circ}$ ano, a questão é a diversidade e a pluralidade das expressões artísticas contemporâneas, gerando possibilidades infinitas de diálogos entre formas de produção, agregando em seu aprendizado as dimensões multiculturais e antropológicas da arte [p. 174].

Acreditamos que uma perspectiva possível para se entender a arte, assim como toda construção cultural, é vê-la como resultante de um choque dialético entre o homem e o mundo, entre o sujeito e o objeto, entre o ser e a matéria, entre o eu e o outro. A dimensão entre sujeito e objeto, entre identidade e alteridade, pareceunos uma maneira apropriada de se abordar as manifestações artísticas dentro dos objetivos traçados para o Ensino Médio nos Referenciais alagoanos. Dessa maneira, o ensino de Arte poderia se especializar sem perder sua potência transdisciplinar através do olhar diferenciado da Filosofia e da Sociologia.

A proposta é que os alunos do primeiro ano realizem seus estudos da Arte a partir do ponto de vista subjetivo de sua produção, isto é, das formas artísticas como expressão predominantemente do sujeito. Abordaríamos seus aspectos filosóficos, psicológicos e religiosos, estabelecendo como atitude esperada dos estudantes ao final do ano letivo o "uso das formas de pensamento artístico para o conhecimento de si próprio e do outro" (p. 121). O segundo ano seria dedicado ao predomínio das expressões objetivas, aquelas que procuram estabelecer a comunicação entre os homens a partir dos elementos comuns da cultura e da linguagem. Estudar-se-ia, desta forma, a Arte sob o ponto de vista da sociologia, da política e das 
comunicações, desejando que os estudantes abordassem e utilizassem a "arte como forma de comunicação e transformação do mundo" (p. 122). A atitude desejada dos alunos ao final do terceiro ano é de que eles adquirissem a "percepção das produções artísticas contemporâneas como formas de expressão e comunicação entre os homens" (p. 123), desta forma, os estudos estariam voltados às formas artísticas contemporâneas dentro de uma perspectiva que procurasse sintetizar os estudos dos dois primeiros anos.

No primeiro ano do Ensino Médio, através do estudo e da análise dos aspectos subjetivos das manifestações artísticas, a Filosofia poderia atuar no estudo de conceitos como arte, estética e poética, belo e feio, sublime e grotesco, e também através do pensamento sobre a arte de várias civilizações. Como o Homem se manifesta esteticamente, como ele se relaciona consigo mesmo, como a arte pode agir no mundo psíquico e metafísico do ser. Os estudos neste ano podem ser direcionados em seus aspectos analíticos e de apreciação para aqueles artistas, movimentos e comunidades que privilegiaram as manifestações subjetivas e metafísicas. O fazer artístico pautado na expressão da individualidade, na subjetivação.

Já os alunos do segundo ano realizariam seus estudos, análises, apreciações e experimentos artísticos a partir do objeto, tendo como eixo norteador Arte e Sociedade (p. 122). Aquela Filosofia que não se restringe aos aspectos subjetivos do ser aliada à Sociologia seriam os operadores privilegiados para o estudo das relações do homem com os homens e com o mundo em seus aspectos comunicacionais. Os conteúdos conceituais privilegiados neste ano seriam aqueles movimentos, artistas e sociedades que trabalham a arte sob a perspectiva de transformação do mundo. A arte como instrumento de ação política, social, cultural, religiosa, nas relações entre os homens.

A síntese deste choque dialético entre sujeito e objeto aconteceria no terceiro ano através dos estudos da arte produzida na atualidade. Qualquer período artístico ou artista que faça parte do cânone das artes mundiais serviria como operador neste exercício de síntese. Acreditamos que a grande arte, aquela que serve como referencial cultural dos homens, carrega em si esta capacidade de sintetizar os aspectos individuais e coletivos da humanidade. Optamos pelo estudo da arte 
contemporânea no último ano da educação básica por ser aquela que tem em si, em potência, todas as realizações culturais da humanidade. Além do que, os estudantes neste período escolar estarão em contato com as produções mais recentes do Homem, seja nas áreas das ciências da natureza, seja nos estudos da geopolítica e da história contemporâneas.

Diante da dificuldade de definição do que seria arte contemporânea, optamos por um recorte histórico elegendo o final da Segunda Guerra Mundial como um possível marco inicial. Após a explosão da bomba atômica em Hiroshima e Nagasaki e a descoberta dos experimentos realizados nos campos de concentração nazistas, modificou-se "todo o pensamento e todo o imaginário processados até então", segundo Luiz Nazario (NAZARIO, 2005, p. 25).

Em Auschwitz e em Hiroshima, o mal absoluto irrompeu no mundo, provando possuir uma realidade histórica: o poder total concedido à tecnocracia, pela evolução da burocracia e da tecnologia, tornou possíveis a destruição da essência humana e a extinção do homo sapiens [p. 25, grifo do autor].

Em termos geopolíticos, a segunda metade do século XX é marcada pela chamada Guerra Fria entre os Estados Unidos da América e a União Soviética, que, com o fim desta, em 1992, se transformará em hegemonia dos americanos e na mundialização da sociedade de consumo. A explosão da bomba atômica e a descoberta dos experimentos nazistas marcaram o início da crise do projeto lluminista, de crença absoluta na razão e no pensamento científico, que deveria ter levado a humanidade através do progresso tecnológico ao "paraíso na terra". O horror dos campos de concentração levou Adorno a afirmar que "a exigência que Auschwitz não se repita é a primeira de todas para a educação" (ADORNO, 1995, p. 119), contrapondo-se, dessa maneira, a uma sociedade na qual "pessoas que se enquadram cegamente em coletivos convertem a si próprios em algo como um material, dissolvendo-se como seres autodeterminados" (p. 129). A civilização ocidental passou a questionar as narrativas unificantes e totalizadoras de nossa história e, segundo J. Guinsburg, consumou-se a "implosão das principais categorias pelas quais o mundo era pensado e vivido" (GUINSBURG, 2005, p. 14). Neste contexto as artes podem ser tomadas ao mesmo tempo como um reflexo e como pensamento em ação sobre esta crise. "O mundo das artes e das representações 
simbólicas viu-se diante da necessidade de refugar meios e formas de expressão consagrados ou obsoletos que não mais serviam à assimilação e ao relacionamento com essa realidade" (p. 14). Os limites entre as linguagens artísticas passaram a ser questionados. A própria arte passou a ser conceituada de novo, praticamente a cada obra. Até mesmo os limites entre arte e cotidiano estão sendo revistos, pois o que era vida comum passou a ser lido como expressão artística; o que era somente expressão artística passou a fazer parte da vida cotidiana das pessoas.

\subsubsection{A implantação dos Referenciais Curriculares alagoanos}

Os Referenciais Curriculares para a Educação Básica da Rede Estadual de Ensino de Alagoas vieram a público em agosto de 2014 e, portanto, se encontram em fase de implantação. Infelizmente não acompanho esse momento do processo, que considero o mais importante para se entender onde estão as fragilidades das proposições aqui expostas. As escolhas e propostas apresentadas precisam ser amadurecidas através de sua colocação na vida diária da sala de aula para que se possa ter a real noção da interação entre prática e teoria. Trata-se de proposta que procura nortear a organização curricular da educação básica no que se refere ao ensino das artes, mas que não tem a pretensão de enfrentar problemas que acredito estruturais nesta área.

É necessário reconhecer que o que se propôs não enfrenta as muitas questões abertas no primeiro capítulo desta tese, como, por exemplo, o paradoxo da formação do professor de Arte especializado e a demanda por um professor polivalente; a ausência de espaço físico adequado para a produção teatral; a precariedade de acesso a materiais poéticos para se desenvolver processos de fruição, apreciação e, principalmente, de leitura da obra artística; o tempo de aula escasso (50 minutos semanais) para se desenvolver abordagens triangulares dos inúmeros conteúdos conceituais sugeridos; a ausência de livros e materiais didáticos especializados nas linguagens artísticas; entre outros. 
Por outro lado, espera-se que a partir da execução do projeto e de seus ajustes aos poucos a comunidade escolar passe a compreender a singularidade das artes como formas de pensar o mundo e agir nele, tão importantes quanto as demais áreas de conhecimento escolar; e que os direitos de aprendizagem dos alunos efetivamente se realizem, organizando os sete anos de estudos seriados dos estudantes alagoanos no Ensino Fundamental II e no Ensino Médio, independentemente dos locais onde se realizará esta formação e de eventuais mudanças de professores. O próximo passo seria estudar como a implantação está sendo realizada, quais são as dificuldades para que a proposta se concretize e quais seriam as modificações necessárias.

\subsection{Uma proposta para o curso de Teatro Licenciatura da UFAL}

O segundo "poema" ou ato significativo que possa interferir no ensino de Arte na Educação Básica alagoana de que participei durante o desenvolvimento desta pesquisa refere-se à construção do Projeto Pedagógico do Curso (PPC) de Teatro Licenciatura da Universidade Federal de Alagoas (UFAL). Assim como os Referenciais Curriculares de Alagoas, este documento também foi realizado coletivamente, neste caso pelos docentes do curso e pelos alunos desta licenciatura, através dos representantes do Centro Acadêmico dos Estudantes de Teatro (CAETE). Como coordenador do curso, coube-me a incumbência de conduzir o processo articulando as diversas sugestões, incorporando passagens do antigo PPC, de 2006, de projetos pedagógicos de outros cursos da UFAL e de outras licenciaturas em Teatro de universidades federais brasileiras, e realizar a redação final.

A necessidade de se construir um novo PPC para a licenciatura em Teatro da UFAL decorreu da avaliação negativa do curso realizada pelo Ministério da Educação (e.MEC, 2014), em maio de 2014. Diversas intervenções foram solicitadas visando uma futura reavaliação, dentre elas, a adequação do PPC às mais recentes exigências da legislação educacional. Por outro lado, os professores do curso há muito desejávamos atualizar o projeto pedagógico com a eliminação, alteração e 
criação de novas disciplinas, adequando-as ao perfil do corpo docente e visando as necessidades de formação do Professor de Teatro. Particularmente, parecia-me que este seria um momento propício não somente para uma renovação ou atualização do Projeto Pedagógico, mas para uma transformação completa no perfil do curso, visando inseri-lo de maneira crítica e dialógica no ambiente educacional, cultural, artístico e teatral de Alagoas.

O desejo de "criar" um curso que dialogasse com o contexto alagoano existia desde minha chegada ao estado, em 2012, quando, em conversa com um aluno na tentativa de entender o contexto em que estava atuando (novo para mim), ele destacou a necessidade da Universidade se aproximar da riqueza das manifestações artísticas da tradição popular alagoana. Parecia-me uma perspectiva próxima ao curso de formação do Educador Brincante oferecido pelo Teatro Escola Brincante, de São Paulo, capitaneado por Antonio Nóbrega e Rosane Almeida, e que poderia ser ampliada com a criação de uma futura licenciatura na UFAL que dialogasse diretamente com esses saberes artísticos da tradição popular.

Em reunião de orientação para a presente pesquisa, a Prof ${ }^{a}$ Dra Maria Thaís observou que a formação do Professor de Teatro realizada na UFAL, na qual eu detectava um distanciamento das necessidades da Educação Básica, e o sonho de criação de uma licenciatura que formasse educadores brincantes - que dialogassem com a arte de tradição popular alagoana e brasileira e com seus mestres brincantes, valorizando e legitimando estes saberes na academia e na escola - estavam conectados. A necessidade de se produzir um novo PPC para a licenciatura em Teatro da UFAL configurava-se como o momento histórico para se criar esta nova licenciatura. Nas palavras de Guimarães Rosa, "Deus faz a mira, o diabo puxa o gatilho..."

De volta às Alagoas, em reunião do Núcleo Docente Estruturante (NDE) integrado pelos professores do curso de Teatro com o objetivo de refletir sobre os nossos processos pedagógicos e responsável pela elaboração do novo PPC foi lançada uma provocação para iniciar os trabalhos: para sabermos qual curso de Teatro queremos é preciso que cada um exponha o que pensa e o que é teatro para si. Naquela pequena sala havia muitos teatros, diversas visões sobre a linguagem e uma pluralidade de perspectivas pedagógicas. Era preciso encontrar um interesse 
comum. Fiz um "lance de dados" argumentando em forma de questão: o que é teatro para a população alagoana? Se estamos formando professores de Arte para todo o estado, qual é o teatro que se faz em Maceió e nas cidades do interior de Alagoas? As respostas foram se distanciando daquele teatro feito "em grandes casas, sob sóis artificiais / Diante da multidão calada" (BRECHT, 1986. p. 238) e se dirigindo para "aquele teatro encenado na rua" (p. 238) e nas praças, e presente nas manifestações dramáticas e espetaculares da tradição popular alagoana.

Outros argumentos foram arrolados na fase de escrita do documento que corroboravam com esta nova orientação pretendida pelo NDE. Levava-se em conta que em Alagoas somente 16 de seus 102 municípios possuem teatro, de acordo com dados do IBGE (Instituto Brasileiro de Geografia e Estatística) (UFAL, 2014, p. 27), e que uma das funções da universidade através do curso de graduação em Licenciatura é "prover a formação de recursos humanos aptos para o exercício da docência na Educação Básica do Brasil” (p. 16), segundo o Projeto Pedagógico Institucional (PPI) da UFAL. Desta forma, seria oportuna uma licenciatura em Teatro na qual a maioria dos formandos irá atuar como professor em escolas de Alagoas que refletisse sobre, de um lado, a riqueza da cultura popular do estado e, de outro, o precário investimento dos órgãos públicos em equipamentos culturais como teatros e centros culturais.

É importante frisar uma das características do curso de Teatro da UFAL, que possui dez professores em seu corpo docente, sendo que sou o único que não desenvolve um projeto de pesquisa acadêmica sobre as manifestações artísticas de tradição popular. Todos os demais docentes estudam e/ou atuam em grupos teatrais alagoanos inspirados pela tradição popular ou diretamente nestas manifestações, como o coco, os pastoris, o boi alagoano, os blocos carnavalescos. Entendemos que era o momento de realizarmos efetivamente o que a universidade se propõe, aliar as atividades de ensino às de pesquisa e extensão. O momento de articular as obrigações acadêmicas dos professores e o seu fazer teatral. O momento de legitimar na academia as formas artísticas tradicionais e reconhecer os seus mestres brincantes artistas. O momento de aproximar o ensino de Arte na escola das artes realizadas no estado de Alagoas. 
O objetivo do novo Projeto Pedagógico do Curso de Teatro Licenciatura da UFAL é o de "reformar seu conceito pedagógico e suas metodologias de aprendizagem, adequando-o à legislação vigente e às novas demandas surgidas no contexto da educação superior no Brasil nos últimos oito anos" (p. 02). Não é o caso aqui de apresentar as adequações à legislação nem mesmo de algumas estruturas comuns a várias licenciaturas em Teatro do país, mas sublinhar alguns pontos desta reforma que se referem ao conceito pedagógico e às metodologias de aprendizagem que, de alguma maneira, dialogam com a presente pesquisa na procura de novas veredas para analisar as questões abordadas anteriormente: o entendimento ampliado sobre a linguagem teatral a partir de uma perspectiva que não esteja demasiadamente presa a conceitos eurocêntricos; o estudo do teatro como composição de elementos cênicos advindos de diversas linguagens artísticas; e no reconhecimento das pedagogias oriundas da tradição popular.

\subsubsection{Uma perspectiva ampliada de teatro}

Ao reconhecermos as manifestações dramáticas e espetaculares da tradição popular alagoana e brasileira como formas de teatro norteadoras dos estudos e das pesquisas acadêmicas na formação de professores propomos um entendimento ampliado sobre as fronteiras da linguagem teatral dentro da universidade. Estamos friccionando alguns conceitos e perspectivas do teatro, de suas pedagogias e das pedagogias voltadas à Educação Básica para os quais talvez não existam sínteses tranquilizadoras, mas tensões constantes.

O movimento em direção às manifestações culturais da tradição popular de Alagoas, especificamente àquelas que contêm elementos espetaculares $e$ dramáticos, além do caráter político e de afirmação cultural, também vai ao encontro do artigo 26, da LDB no 9.394, de 1996, que traz em seu texto, " $§ 2^{\circ} \mathrm{O}$ ensino da Arte, especialmente em suas expressões regionais, constituirá componente curricular obrigatório nos diversos níveis da educação básica, de forma a promover o 
desenvolvimento cultural dos alunos" (BRASIL, 1996, grifo nosso) ${ }^{30}$. Para nossa proposta de curso, não se trata de negar as expressões e manifestações artísticas da tradição teatral, mas de legitimar a arte vinda da tradição popular alagoana tomando-a também como parâmetro para o ensino do teatro e para a formação do Professor de Arte para a Educação Básica, visto que será em Alagoas que a maioria dos formados exercerá suas atividades docentes e artísticas.

Diante desta perspectiva de atuação profissional dos professores de Teatro formados pela UFAL, o novo PPC também contempla as indicações para o componente Arte presentes nos novos Referenciais Curriculares para a Educação Básica da Rede de Ensino Estadual de Alagoas. Como foi exposto na primeira parte deste capítulo, o processo de aprendizagem para o Ensino Fundamental II, em Alagoas, propõem como norteador para a sequência curricular as relações corporais do aluno com seu espaço a partir de sua casa em direção à produção artística da humanidade, passando por seu bairro, cidade, estado e país. Assim, os Referenciais Curriculares alagoanos ao indicarem a necessidade de estudo das manifestações culturais de tradição popular legitimam, entre outros, os folguedos e brincadeiras dramáticas oriundas desta tradição como formas teatrais, que são profusas nas cidades do interior e nos bairros da capital de Alagoas. $O$ teatro, ainda que dialogue com as mais diversas formas de produção e criação, mantém seu caráter presencial e artesanal e encontra nas brincadeiras dos artistas e mestres da cultura popular, nos nossos brincantes, nos pequenos circos mambembes e nas representações teatrais religiosas como a Paixão de Cristo, uma herança inesgotável e recorrente.

Ainda que sobreviva como senso comum, é preciso ressaltar a arbitrariedade das divisões que procuram estabelecer fronteiras entre formas e práticas teatrais onde, de fato, não existem. Não podemos ignorar que a influência da indústria cultural no imaginário e nas expressões oriundas das tradições populares é forte e pode ser constatada, por exemplo, nos concursos de quadrilhas juninas, cocos e bois de Alagoas. Além da espetacularização, influenciada nas sonoridades e visualidades presentes nos produtos da indústria cultural, observa-se cada vez mais uma estrutura dramatúrgica inspirada nos enredos das escolas de samba do Rio de

30 A expressão "especialmente em suas expressões regionais" foi acrescentada ao documento no ano de 2010 , através da Lei $n$ 을 2.287, promulgada pelo presidente Luís Inácio Lula da Silva. 
Janeiro, apagando, por vezes, as características que as distingue como folguedo. Nas brincadeiras populares não se representa mais o casamento de matutos (quadrilha) ou a vida e a morte do boi, mas contam-se histórias de Lampião e Maria Bonita, homenageiam-se personalidades artísticas como Luiz Gonzaga ou a cultura nordestina. Trata-se de apresentações temáticas nas quais ainda subsistem as personagens (figuras) das brincadeiras originais, porém com suas funções modificadas.

Assim, procurando trabalhar a partir das legislações educacionais do país e do estado de Alagoas e não perdendo o senso crítico da arbitrariedade de algumas destas proposições, o PPC estabeleceu como um dos objetivos da Licenciatura em Teatro da UFAL:

Formar docentes e pesquisadores teatrais capacitados para realizar mediações entre os conhecimentos da cultura da tradição popular alagoana e os conhecimentos da chamada cultura acadêmica, dando voz e reconhecendo os saberes dos mestres dessa tradição nos meios universitários e difundindo os saberes acadêmicos em comunidades sem acesso a esses, valorizando, assim, a diversidade cultural brasileira [UFAL, 2014, p. 35, grifo nosso].

O movimento de busca, de pesquisa, de entendimento e, principalmente, do estabelecimento de um diálogo permanente com as formas teatrais da tradição popular alagoana levou-nos a traçar uma Caracterização Conceitual para o curso, através da qual se pretende formar o professor como "um mediador entre [...] dois modos de produção cultural, o popular e o acadêmico/erudito" (p. 17).

\footnotetext{
Importante salientar aqui que não se pretende fazer distinções de valor entre estes modos de produção teatral, nem mesmo privilegiar um em detrimento do outro, visto que ambos comungam dos mesmos elementos que formam a linguagem teatral. $O$ que se quer é criar canais de diálogo em que as formas e poéticas vindas da tradição popular, que têm em seus mestres os máximos representantes artísticos, tenham corpo e voz dentro da universidade e sejam reconhecidas e valorizadas como obras de arte e seus produtores como artistas. Por outro lado, também se deseja que a produção acadêmica e erudita possa ser democratizada sem se transformar em uma "monocultura colonizadora" do imaginário popular ou em uma cultura que se restrinja, em suas formas de produção e fruição, às elites econômicas. Ressalte-se, ainda, neste contexto, a importância de estudos críticos dentro da universidade da produção artística inserida na indústria cultural para a formação do professor de teatro em Alagoas [p. 17, grifos nossos].
}

Há uma preocupação constante em se criar um diálogo franco, aberto, que evite a estigmatização e a guetificação dos conhecimentos locais e universais. A 
troca de saberes é fundamental para que não se estabeleça uma visão de cultura criadora de guetos na qual a comunidade fique refém de sua própria produção artística. Como se, ao se valorizar, por exemplo, o Guerreiro alagoano, a comunidade não pudesse estudar balé clássico ou tocar oboé. Ou onde um "estrangeiro" à comunidade não pudesse brincar. Para a etnóloga Manuela Carneiro da Cunha, é preciso distinguir cultura, enquanto categoria analítica, como "esquemas interiorizados que organizam a percepção e a ação das pessoas e que garantem um certo grau de comunicação em grupos sociais" (CUNHA, 2009, p. 313), na qual o indivíduo é parte de um todo social, de "cultura" (com aspas) da qual supõe-se que as invenções são de autoria coletiva e na qual o discurso age "como recurso e como arma para afirmar identidade, dignidade e poder diante de Estados nacionais ou da comunidade internacional" (p. 373). Ou seja, na "cultura" a unidade deixa de ser o indivíduo para se constituir na própria comunidade. Assim, a ideia que perpassa todo o PPC é a de friccionar conceitos como patrimônio cultural da humanidade e manifestações artísticas oriundas das tradições populares, de cultura e "cultura", entre outros.

Ainda que considerada necessária, a conceituação do que o corpo docente de Teatro Licenciatura da UFAL entende como manifestações artísticas das tradições populares não foi realizada no documento porque, além de divergências entre os próprios professores, justificou-se que "se o que se quer é estabelecer diálogos, atritos e fricções entre a universidade e a comunidade, tal conceituação pode vir a ser uma restrição inicial a estes objetivos de interação e mediação" (UFAL, 2014, p. 18). Procurou-se, em lugar de um conceito fechado, identificar ou indicar um território, as formas de produção e, ainda, alguns elementos recorrentes, que nos auxiliam a traçar as fronteiras de nosso projeto.

O território a que nos referimos como Cultura Popular de Tradição de Alagoas sociologicamente refere-se àquelas manifestações artísticas vindas de camadas da população desfavorecidas economicamente e que habitam o território do estado de Alagoas. Tais manifestações não se limitam necessariamente a uma pressuposta origem alagoana ou se restringem ao que se possa chamar de "identidade alagoana", mas fazem parte do imaginário de uma comunidade estabelecida geograficamente neste território [p. 18]. 
Observe-se que na tentativa de identificar um território o documento comete o equívoco de "privatizar" as manifestações da tradição popular em uma determinada classe econômica, dando-Ihe a exclusividade sobre essa produção artística e cultural. É importante observar que essas manifestações atravessam o imaginário popular sem se prender a categorias socioeconômicas. A parte esse "deslize", o que se pretende com este recorte é delimitar o campo no qual acontecem as manifestações artísticas sem necessariamente entrar em celeumas e debates sobre a origem histórica e geográfica das brincadeiras. O que nos interessa nessas manifestações são suas formalizações cênicas e seus modos pedagógicos de transmissão, hoje, dentro de suas comunidades. Não se descartam pesquisas históricas e etnográficas sobre as origens e trajetórias que as manifestações percorreram, porém parece-nos que essas abordagens poderiam nos levar a eleger determinadas brincadeiras em prejuízo de outras a partir de juízos de valor externos à própria manifestação. Seria como dar uma "chancela acadêmica" a uns a partir de perspectivas que só interessariam à própria universidade, fechando os olhos a outros e, assim, deslegitimando-os. Manuela Carneiro da Cunha observa que o sentido de "autoria coletiva", muitas vezes presente em discursos de "identidade cultural", se deve a origem antropológica que se deu ao termo "cultura" e que este não deveria ser entendido de maneira totalizante:

O termo "cultura", em seu uso antropológico, surgiu na Alemanha setecentista e de início estava relacionado à noção de alguma qualidade original, um espírito ou essência que aglutinaria as pessoas em nações e separaria as nações umas das outras. Relacionava-se também a ideia de que essa originalidade nasceria das distintas visões de mundo de diferentes povos. Concebia-se que os povos seriam os "autores" dessas visões de mundo. Esse sentido de autoria coletiva e endógena permanece até hoje [CUNHA, 2009, p. 354, grifos nossos].

A etnóloga observa que não podemos nos restringir a esta perspectiva única de cultura, pois em quase todas as sociedades amazônicas, por exemplo, "costumes, cantos, cerimônias, saberes e técnicas têm por definição uma origem alheia" (p. 360), ou seja, são exógenas. Para ela, não cabe na restrita imaginação das sociedades industrializadas "que povos inteiros [...] possam pensar suas culturas como exógenas, obtidas de outrem" (p. 329), concluindo, dessa maneira, que a “"autenticidade’ é uma questão indecidível” (p. 343, grifo da autora). 
Sendo nosso foco o teatro e a pedagogia, interessa-nos que o Professor de Teatro formado pela UFAL saiba "reconhecer a importância das manifestações artísticas na sua comunidade, em sua cidade, em seu estado, no país e no mundo" (UFAL, 2014, p. 39). Quando no exercício da docência, possa olhar para a comunidade na qual está inserida sua escola e saiba detectar e valorizar as manifestações teatrais ali presentes e, principalmente, trabalhar a partir delas, valorizando a voz, a presença e os saberes dos artistas e mestres locais, realizando a mediação destas formas com os estudos teatrais e as pesquisas desenvolvidas na vida acadêmica.

Em Alagoas, a forte presença das manifestações artísticas oriundas da tradição popular pode ser constatada através de dados divulgados pela Fundação Municipal de Ação Cultural de Maceió (FMAC), segundo os quais o estado possui "treze folguedos natalinos, dois folguedos de festas religiosas, oito folguedos carnavalescos, sendo quatro com estrutura simples, três danças e dois torés, totalizando vinte e nove folguedos e danças genuinamente alagoanos" (UFAL, 2014, p. 28). Ao descartarmos a pretensa "origem" ou "autenticidade" alagoana e privilegiarmos a importância das manifestações espetaculares em si para suas comunidades e a riqueza de suas formalizações estéticas, entendendo que os deslocamentos geográficos são, muitas vezes, parte intrínseca das poéticas das brincadeiras e de suas formalizações cênicas, percebemos que as manifestações artísticas da tradição popular passam das três dezenas e estão presentes nos 102 municípios alagoanos, tornando-se um material artístico e pedagógico riquíssimo.

Nestes "territórios fluídos e passíveis de criação de novas fronteiras" (p. 18), o PPC propõe algumas delimitações, ainda que construídas mais por negativas do que por assertivas:

Os mestres populares, ainda que alfabetizados, dificilmente se expressam através de uma cultura letrada; transmitem seus ensinamentos de forma oral e reproduzem as formas e modos como eles próprios se formaram, ressaltando-se ainda que muitos sejam autodidatas. Sua arte é sua forma de expressão e produção de conhecimento. Essa expressão não tem o caráter de ineditismo ou de novidade, muitas vezes presente na arte erudita. Os materiais poéticos já estão formalizados pela tradição, através de gerações, o que não significa que não dialoguem com o mundo, em seus movimentos e transformações, gerando sempre novas formas de expressão e comunicação. Tal formulação nos afasta da conceituação folclórica que por ventura essas manifestações venham a carregar através do olhar estrangeiro a elas 
(estrangeiro aqui no sentido de estranho). Este olhar pressupõe que a manifestação artística esteja congelada no tempo e no espaço, e que suas formas e poéticas não são atualizadas, deixando de dialogar com o mundo. Nada mais distante do que pensamos. A cultura de tradição popular é, pois, uma cultura em constante transformação [p. 18, grifos nossos].

A propósito da oralidade na transmissão desse conhecimento da tradição popular, Richard Sennett, referindo-se ao recurso largamente explorado de substituir as palavras pelas imagens na Enciclopédia, ou Dicionário de artes e ofícios, editado em grande parte por Denis Diderot, no século XVIII, observa que "o trabalho artesanal cria um mundo de habilidade e conhecimento que talvez não esteja ao alcance da capacidade verbal humana explicar" (SENNETT, 2009, p. 111). De certa maneira, trata-se de recurso semelhante à utilização da linguagem audiovisual para tutoriais de "como fazer", disseminados pelo mundo através do Youtube, no século XXI. Para Sennett, a dificuldade em descrever em palavras os processos de produção revela mais os limites da linguagem do que a incapacidade de articulação do pensamento: "desarticulado não quer dizer burro; com efeito, o que somos capazes de dizer com palavras pode ser mais limitado que aquilo que fazemos com as coisas" (p. 111), sendo assim, "os limites da linguagem podem ser transcendidos pelo envolvimento ativo numa prática" (p. 112).

A expressão utilizada para a transmissão dos ensinamentos na "forma oral", citada no documento, pode se referir não à ausência de textos escritos, mas à impossibilidade mesma de transformar em linguagem escrita um conhecimento que é tácito e que só pode ser apreendido por meio do desenvolvimento de habilidades e de experimentações em contato com a própria matéria, ou seja, "com a mão na massa". O que remete à pedagogia do "aprender fazendo", criticada nos capítulos anteriores enquanto modalidade de aprendizagem para a Educação Básica. No caso deste trabalho, seria o escorpião encalacrado aferroando a si próprio?

Talvez não, porque aqui se discorre sobre a formação do Professor de Teatro, um ofício que requer o aprendizado de habilidades e modos de transmissão específicos da linguagem teatral, que se diferencia da formação do cidadão e do sujeito emancipado, este objetivo da Educação Básica, para a qual defendemos a ênfase na leitura e não no fazer. Talvez sim, por outro lado, porque o que o PPC de 
Teatro Licenciatura da UFAL propõe para o exercício do ofício Professor de Teatro é incluir a mediação entre a tradição do teatro de origem europeia e as manifestações dramáticas da tradição popular e ambas possuem modalidades de transmissão que, aparentemente, só podem ser apreendidas através do fazer. Sobre a simples aplicação do "aprender fazendo" na educação, Sennett observa que:

expondo-nos à prática, ousando fazer, podemos ter de entender o fracasso e não propriamente o erro, reconhecer limites de capacitação a cujo respeito nada podemos fazer. Nesse sentido, aprender fazendo, panaceia tão reconfortante da educação progressiva, pode ser na verdade cruel [p. 113, grifos do autor].

Como já foi dito acima, não há sínteses tranquilizadoras, mas tensões constantes.

Outra delimitação do que seriam as manifestações da tradição popular alagoana, citada acima, refere-se ao caráter de suas formalizações e modos de transmissão já conhecidos, isto é, em princípio avessos ao ineditismo e à novidade. A perspectiva de arte como a reprodução perene do que se dá a ver não é uma singularidade da "cultura" popular alagoana e brasileira, pois pode ser encontrada, por exemplo, em manifestações teatrais clássicas do oriente, como o Teatro Nô japonês e o Kathakali indiano. A questão talvez não se refira a um suposto conflito de "tradição versus inovação", mas na valorização da originalidade que remontaria, segundo Sennett, aos artistas renascentistas e que se transformaria em direito jurídico sobre a propriedade intelectual, na perspectiva de Manuela Carneiro da Cunha.

Para Sennett, a valorização da originalidade resultaria na criação de uma distinção entre arte e artesanato: "[A arte] representa a concessão de um novo e mais amplo privilégio à subjetividade na sociedade moderna, com o artífice voltado para sua comunidade e o artista voltado para si mesmo" (p. 80). A originalidade seria vista, assim, como característica dos indivíduos sozinhos, isolados, e a palavra arte passaria a designar obras únicas ou singulares, "ao passo que artesanato remete a práticas mais anônimas, coletivas e contínuas" (p. 81). O próprio Sennett assinala que "é preciso desconfiar desse contraste" (p. 81), pois a originalidade é um rótulo social, o que remeteria, a nosso ver, aos discursos sobre a arte problematizados no 
segundo capítulo e suas formas de recepção e catalogação, e não ao objeto artístico em si.

Manuela Carneiro da Cunha, por sua vez, observa que "a construção contemporânea dos direitos de propriedade intelectual tem em sua base a noção romântica do autor criativo que constrói uma obra original ab nihilo" (CUNHA, 2009, p. 367), o que se constitui em uma falácia que se aplica à criação artística e à invenção científica: "A concepção demiúrgica de uma autoria que parece baixar por inspiração divina omite as contribuições intelectuais coletivas e individuais em que se fundam a invenção e a criação" (p. 367).

Ou seja, o PPC de Teatro Licenciatura da UFAL procura, mais uma vez, reafirmar uma perspectiva ampliada sobre a linguagem teatral que possa nos possibilitar um olhar sobre o teatro que se faz no mundo a partir de suas próprias expressões, do que se dá a ver, e de seus modos pedagógicos, e não reduzi-los a categorias classificatórias e, em geral, excludentes.

Categorizações que também detectamos na perspectiva folclórica que, em geral, procura normatizar as práticas, as poéticas e as formalizações estéticas das manifestações artísticas, estabelecendo o que é e o que não é característico de cada uma a partir de premissas construídas por meio de percepções externas aos próprios modos de produção. De certa maneira, esta perspectiva torna a própria manifestação refém de sua história e incapaz de se comunicar com seu tempo e contradiz a noção de conhecimentos tradicionais que, segundo Manuela da Cunha, vem se formando na "literatura jurídica e nas declarações de movimentos indígenas internacionais" (p. 264), ou seja:

os conhecimentos tradicionais não são simplesmente um corpus estabilizado de origem imemorial, e sim conjuntos duradouros de formas particulares de gerar conhecimentos. O conhecimento tradicional, segundo essa visão, não é necessariamente antigo. Tradicionais são seus procedimentos - suas formas, e não seus referentes [p. 364].

O que se observa nessas manifestações é que o novo (a novidade) é incorporado à brincadeira pela própria necessidade de comunicação em um 
processo dialógico intrínseco à própria comunidade, pois baseado em referenciais comuns e não como necessário para que a manifestação se realize.

Registre-se, porém, que aqui não é possível estabelecer delimitações que se queiram totalizadoras, pois em manifestações como a quadrilha e o boi alagoano, que se organizam para apresentações em festivais competitivos, tais como nos desfiles de escolas de samba, o que se valoriza são os elementos inéditos, as novidades incorporadas à apresentação ano a ano. Ressalte-se, porém, que existe uma preocupação em preservar elementos estruturantes dessas encenações ligadas à tradição que se revelam nos regulamentos e critérios de avaliação desses festivais, ou seja, é preciso existir a figura do Boi e do Vaqueiro, ou do casal de Noivos e do Padre, na quadrilha junina, entre outros.

Ao lado da negação da perspectiva folclorizante, soma-se ainda a recusa em utilizar o termo etnocenologia no documento. Segundo Patrice Pavis, esta nova disciplina "amplia o estudo do teatro ocidental para as práticas espetaculares do mundo inteiro, [...] sem projetar nessas práticas uma visão eurocêntrica" (PAVIS, 1999, p. 152). Acreditamos, pelo contrário, que a necessidade em se criar uma disciplina para estudar o que não se enquadra no que se entende por teatro nesta perspectiva europeia denuncia, por si só, uma ação colonizadora das antigas metrópoles em relação a suas antigas colônias, para usarmos os termos de Manuela Carneiro da Cunha: "categorias analíticas [...] fabricadas no centro e exportadas para o resto do mundo" (CUNHA, 2009, p. 311). Utilizar o termo etnocenologia no PPC seria, para nós, naquele momento, reafirmar uma perspectiva que precisa adjetivar toda manifestação estética espetacular que não faça parte de sua própria tradição artístico-cultural. Ou seja, o parâmetro do que é teatro viria de um olhar estrangeiro à própria manifestação e o que não correspondesse a ele se tornaria um teatro "diferente" para o qual é necessário se criar uma nova disciplina de estudo.

A não utilização do termo etnocenologia no PPC não significa, entretanto, a discordância em relação à disciplina, pois reconhecemos que muitos estudos acadêmicos vêm sendo desenvolvidos em universidades brasileiras a partir desta perspectiva e, como consequência, legitimando as formas teatrais oriundas da tradição popular. A omissão do termo se caracterizaria como uma tentativa de coexistência, de se estabelecer multiplicidades, de não se criar fronteiras e 
perspectivas muito rígidas que possam vir a se tornar uma nova forma de classificação normativa e que em lugar de abrir o mundo do teatro para o estudo e a experimentação de formas diversas, fecham-no em categorias, por vezes excludentes e totalizadoras.

Outra negação presente no PPC se refere ao termo artesanato, visto sob um possível rótulo depreciativo, para se referir às artes de tradição popular:

O teatro é, essencialmente, uma arte construída através do domínio técnico, portanto, por meio da artesania de seus criadores. O rótulo de artesanato para as manifestações cênicas de tradição popular podem, em nossa opinião, se aproximar mais de uma cultura extrativista, como a dos grupos para-folclóricos, que muitas vezes se utilizam das formas expressivas populares para a produção de espetáculos inseridos em contextos mercadológicos, ainda que em seus discursos predominem os objetivos de preservação [UFAL, 2014, p. 19, grifos nossos].

Percebe-se no texto uma confusão em relação ao termo artesanato, associando-o a uma intenção de desvalorização da obra por meio da qual se reconheceria nas manifestações da tradição popular uma expressão artística menor, sem autoria ou de autoria anônima. Parece-nos, hoje, que a negação ao termo artesanato está equivocada, pois o que se depreende do texto é outra negação: a de uma cultura chamada de extrativista que seria representada pelos grupos parafolclóricos. Talvez a confusão venha da associação de artesanato somente à reprodução de peças ad infinitum, cópias de cópias que perdem, aos poucos, seu valor de expressão artística limitando-se aos seus valores de troca.

O texto, por outro lado, procura valorizar e legitimar a artesania presente em todo processo artístico, como observado por Mario de Andrade (1963, p. 10) ${ }^{31}$. Andrade observa que o caráter artesanal presente em toda obra de arte é passível de aprendizagem: "O artesanato, os segredos, os caprichos, as exigências do material, isto é assunto ensinável, e de ensinamento por muitas partes dogmático, a que fugir será sempre prejudicial para a obra de arte" (p. 10, grifo do autor).

De forma mais direta, Richard Sennett afirma que "em termos de prática, não existe arte sem artesanato; a ideia de uma pintura não é uma pintura" (SENNETT,

${ }^{31}$ Cf. p. 117 et seq. 
2009, p. 79). Ou seja, voltamos a algumas observações feitas no terceiro capítulo, a de que o processo de criação artística envolve um fazer que é artesanal e que não está desprovido de pensamento, pois no embate com a matéria - no qual Sennett detecta a resistência e a ambiguidade como "experiências instrutivas" (p. 21) - a obra é pensada/criada. Para exemplificar esta prática, Sennett cita o método de trabalho do arquiteto Renzo Piano, para quem o desenho é, em si, um ato de pensamento: "É perfeitamente característico da abordagem do artífice. Ao mesmo tempo pensar e fazer. Desenhamos e fazemos" (PIANO apud SENNETT, 2009, p. 52).

No texto, "cultura extrativista" parece então se referir a ações que, ao não reconhecerem autoria nas obras da tradição popular no sentido da propriedade intelectual aludido por Manuela da Cunha, se apropriam comercialmente dessas manifestações. Ou seja, pessoas e grupos em geral estranhos à comunidade que, mesmo não tendo participado da "plantação", "coletam" as formalizações artísticas e as transformam em "bens" negociáveis, seja no mercado acadêmico, no caso de pesquisadores que se arvoram o direito de propriedade intelectual sobre seus "achados", seja através de espetáculos de grupos para-folclóricos, ou mesmo artísticos. O que chamamos aqui de grupos para-folclóricos são aqueles organizados comercialmente e que reproduzem as manifestações artísticas da tradição popular realizando alterações em alguns de seus elementos para tornar mais "palatável" ao gosto médio seus espetáculos, atendendo a uma clientela de turistas, em hotéis e eventos ligados ao turismo.

O que o PPC de Teatro da UFAL nega nesses grupos, que existem em abundância em Alagoas, é a homogeneização dos corpos dos atuantes, em geral integrados somente por jovens bailarinos, e a estilização inconsequente de elementos da encenação, como: figurinos mais coloridos e que normalmente apelam para uma sensualidade excessiva; o aceleramento do andamento das músicas, com o intuito de deixar a apresentação mais "animada"; a escolha de instrumentos musicais "estranhos" à manifestação porém com sonoridades mais próximas da indústria cultural - por exemplo, a substituição da sanfona por teclados sintetizados -; a ênfase em músicas que apelam para um duplo sentido ligado à sexualidade e que muitas vezes podem não ser tão predominantes na tradição; a tendência em transformar as danças em coreografias mais aéreas, através da introdução de 
saltos, pulos e mesmo na elevação dos passos, ao contrário do sentido mais terreno oriundo da tradição, entre outras estilizações. Entretanto, cabe observar que, por vezes, são justamente estes grupos para-folclóricos que recuperam manifestações tidas como perdidas, criam interesse pelas manifestações originais e até mesmo podem se transformar em fonte de renda para as próprias comunidades.

Voltando ao documento, outra negação presente no PPC se refere a movimentos de preservação e de resgate das manifestações da tradição popular:

"preservação" é outro conceito, ao lado de "resgate", com os quais não pretendemos
utilizar na formação de nossos professores mediadores, ainda que vislumbremos a
necessidade de trabalharmos com eles e que, provavelmente, nossas ações
provoquem movimentos preservacionistas e de resgate de manifestações por
desventura desaparecidas [UFAL, 2014, p.19].

Acreditamos que os termos preservação e resgate carreguem um sentido conservador que procura retirar a obra de arte do mundo conferindo-Ihe uma aura de pureza e de uma presumível autenticidade que a impede de continuar agindo entre os homens. Manuela Carneiro da Cunha observa que os instrumentos internacionais ainda tratam o conhecimento tradicional

como um thesaurus, isto é, um conjunto completo e fechado de lendas e sabedorias transmitidas desde tempos imemoriais e detidas por certas populações humanas, um conjunto de saberes preservados (mas não enriquecidos) pelas gerações atuais. Notese que uma concepção como esta enviesa as políticas públicas na direção do "salvamento". O que passa a importar não é a conservação dos modos de produção dos conhecimentos tradicionais, e sim o resgate e a preservação desses thesaurus, que se compararam a outras tantas "Bibliotecas de Alexandria" [CUNHA, 2009, p. 364].

Trata-se, assim, de retirar das manifestações da tradição a potência transformadora que toda obra de arte carrega em si, em um movimento que deslegitima o próprio conhecimento ali produzido. Como dito mais acima, os procedimentos e formas podem ser tradicionais, mas não o são seus referencias, os quais, através de um processo dialógico, constituem-se em "formas particulares de gerar conhecimentos" (p. 364).

Assim, o perfil que se deseja do egresso do curso de Teatro da UFAL é de 
um profissional que saiba articular os conhecimentos, as práticas, as formas estéticas e os sistemas pedagógicos provenientes da tradição da cultura popular de Alagoas com a cultura teatral universal. É essencial que domine os conhecimentos que lhe possibilitem desenvolver uma educação em teatro que integre tradição, contemporaneidade e diversidade cultural; que saiba fazer dialogar os conhecimentos e as experiências que os alunos possuem fruto do seu meio sócio-cultural, com os saberes da tradição da cultura popular e com o conhecimento advindo de outras culturas; e que, fundamentalmente, possa contribuir para desenvolver e ampliar o universo desse conhecimento [UFAL, 2014, p. 33].

Visto se tratar de uma licenciatura em Teatro que se propõe formar professores de Arte que atuarão como mediadores entre manifestações artísticoculturais diferenciadas, o estudo das poéticas coletivas das comunidades e dos mestres da cultura popular e, principalmente, de suas formas de transmissão do saber artístico torna-se fundamental. O que se espera dos estudantes é que, ao desenvolverem uma atitude de valorização da arte como forma de pensamento, incluam "as produções da cultura de tradição popular de maneira tão qualificada quanto as formas do saber erudito" (p. 38). A necessária fricção entre tradição e contemporaneidade, preservação e inovação, construção do conhecimento e transmissão de conhecimento mostra que o território que estamos entrando não é um local de sínteses e acomodações, mas de constantes atritos e atualizações.

\subsubsection{A arte e a pedagogia do brincante}

Ao tomarmos os mestres da cultura popular como referência e suas obras como parâmetro para o ensino da linguagem teatral e para a formação do Professor de Teatro, dois aspectos relevantes precisam ser considerados: a diversidade de linguagens artísticas presentes em suas produções e as formas de transmissão de sua arte.

O mestre de espetáculos dramáticos da tradição popular conhece toda a brincadeira: dramaturgia, cantos, melodias, instrumentação musical, coreografias, desenhos coreográficos, figurinos, cenografia e objetos cenográficos, sabe "botar as figuras" (representar as personagens) e, por fim, sabe ensinar a brincar. Em geral, conhece e sabe como fazer e como transmitir, possui o domínio técnico, poético e 
pedagógico de sua arte. O mestre está presente em todos os momentos da produção (SENNETT, 2009, pp. 90-1). Neste sentido, podemos reconhecê-lo como um multiartista que transita por todas as linguagens que compõem o universo de sua brincadeira, quando não, de outras brincadeiras mais.

Sua forma múltipla de agir no mundo através de sua arte é similar à formação desejada para o Professor de Teatro, ou seja, o domínio dos elementos que compõem a cena e sua pedagogia. A complexidade presente na arte do mestre da cultura popular abole fronteiras de linguagens, constituindo-se em formas híbridas trabalhadas com apurado domínio da composição. Seu caráter coletivo faz com que o olhar do mestre seja o olhar do todo. O PPC de Teatro da UFAL não faz considerações específicas sobre essa múltipla formação, mas deixa-a implícita através da diversidade de linguagens artísticas abarcadas nas disciplinas presentes em sua Matriz Curricular, que se estrutura em três eixos:

Eixo I-LINGUAGEM TEATRAL: voltado às disciplinas de conteúdos básicos da linguagem teatral relacionadas às teorias da arte e do teatro, à leitura, à produção e à contextualização da obra cênica. [...].

Eixo II-PEDAGOGIAS: voltado às disciplinas relacionadas às teorias e práticas pedagógicas na Educação Básica e aos processos de ensino e aprendizagem na educação não formal da linguagem teatral e da cultura de tradição popular brasileira e, em especial, alagoana [...].

Eixo III-INTEGRADOR: voltado às práticas interdisciplinares, aos temas transversais, à articulação entre teoria e prática artísticas e pedagógicas, às pesquisas docentes e discentes em torno das manifestações da cultura de tradição popular brasileira e, em especial, alagoana, às atividades de extensão desenvolvidas no curso e às práticas de mediação entre as culturas acadêmica e popular, em seus aspectos estéticos, éticos e pedagógicos [UFAL, 2014, p. 62].

As singularidades do projeto pedagógico da licenciatura em Teatro da UFAL, consequência da escolha das manifestações artísticas da tradição popular como norteadoras do processo de formação do Professor de Teatro, aparecem de maneira mais contundente nos eixos II e III, voltados para as pedagogias e para a articulação entre teoria e prática nos processos de ensino e aprendizagem.

No Eixo II - Pedagogias estão as disciplinas pertinentes à formação específica do docente para a Educação Básica ${ }^{32}$ e àquelas voltadas à linguagem teatral na educação. No caso das primeiras, como não poderia de deixar de ser, as

${ }^{32}$ Cf. nota 5 . 
metodologias de ensino e aprendizagem correspondem àquelas presentes nos documentos e na legislação educacional do país que seguem às indicações da UNESCO para a educação no terceiro milênio. Porém, diante do norteador vindo das tradições populares, surgiu a necessidade de se repensar a metodologia de ensino e aprendizagem presente no PPC, pois, como já citado anteriormente, os mestres da tradição cultural "transmitem seus ensinamentos de forma oral e reproduzem as formas e modos como eles próprios se formaram" (p. 18).

[...] a caracterização conceitual do curso, marcada pelo diálogo com o contexto cultural no qual está inserido, coloca uma questão de natureza pedagógica, da qual a metodologia exposta acima não poderá deixar de enfrentar. Ao optar por uma ação de mediação entre a cultura de tradição popular e a cultura acadêmica no plano estético, torna-se necessário também realizar ações de mediação no plano pedagógico.

Problematizar, sob uma perspectiva crítica, os procedimentos de ensinoaprendizagem e as práticas didáticas desses ambientes culturais, em que a construção do conhecimento é realizada por meio de ações pedagógicas distintas, é colocar em questão a própria metodologia do curso apresentada até aqui. Baseada em situações-problema, na ação-reflexão-ação e na prática dialógica, a pedagogia do aprender a aprender, preconizada pelas DCN [Diretrizes Curriculares Nacionais] para os cursos de licenciatura, foi construída no embate contra as pedagogias tradicionais, baseadas na transmissão de formas e conteúdos, saberes e técnicas, nas quais se inserem a arte, a pedagogia e a cultura de tradição popular. Reconhecer este paradoxo significa problematizar os paradigmas da educação preconizados pela Unesco e referendados pelo MEC para este terceiro milênio. O processo pedagógico de formação do professor de teatro, que objetiva a atuação deste como mediador entre estas culturas, deve explicitar e problematizar esta contradição, sob o risco de, ao negá-la, falsear a própria mediação e atuar mais uma vez de forma colonizadora culturalmente e de forma extrativista do patrimônio material e imaterial destas populações desfavorecidas economicamente [p. 45].

Ainda que sem apresentar metodologias para se estudar de forma "crítica" como fazer a mediação entre o pensamento dominante de práticas de ensino vindas das pedagogias do "aprender a aprender" disseminadas no sistema educacional brasileiro e as pedagogias oriundas da tradição popular, baseadas na transmissão dos saberes entre mestre e aprendizes, O PPC de Teatro Licenciatura da UFAL reconhece esse paradoxo e aponta para a necessidade de se repensar criticamente os paradigmas para a educação no século XXI preconizados pela UNESCO.

\subsubsection{Práticas pedagógicas}


A questão "construção versus transmissão" dos conhecimentos é enfrentada pelo PPC através da indicação de algumas formas de abordagem pedagógica que talvez possam colocar em atrito esses pensamentos pedagógicos distintos. Presentes em toda matriz curricular estas práticas se desenvolvem plenamente no Eixo III - Integrador, voltado à interdisciplinaridade, "aos temas transversais, à articulação entre teoria e prática artísticas, às pesquisas docentes e discentes em torno das manifestações da cultura de tradição popular brasileira e, em especial, alagoana" (p. 63). Neste eixo procuramos articular a produção acadêmica do curso através de uma disciplina, Projetos Integradores, dos projetos de Extensão e das atividades de Pesquisa. A disciplina Projetos Integradores, presente em sete dos oito períodos do curso de Teatro, integra o Tronco Comum das Licenciaturas da UFAL ${ }^{33}$, "com o objetivo de articular as teorias e as práticas didático-pedagógicas voltadas à formação do professor da Educação Básica" (p. 63).

O curso Teatro Licenciatura da UFAL estabeleceu, na disciplina Projetos Integradores, como seu operador pedagógico, a construção de um exercício cênico de forma coletiva e colaborativa em diálogo com a cultura de tradição popular. O processo de ensino se desenvolve a partir da articulação dos conteúdos presentes nas disciplinas do período norteados pela prática artística através da criação cênica. Privilegiam-se, desta forma, os processos de aprendizado da linguagem teatral e os procedimentos didático-pedagógicos que fazem parte da formação do professor de teatro com olhar e atenção na cultura popular [p. 63].

Os processos artísticos e pedagógicos de Projetos Integradores são desenvolvidos a partir das disciplinas presentes naquele período letivo e da manifestação artística da tradição escolhida como objeto de estudo e pesquisa. Por exemplo, para os estudantes ingressantes no primeiro período de 2015 escolheu-se como matéria de estudo e experimentação o Boi alagoano. Desta forma, todas as disciplinas do período procuraram formas de dialogar com essa manifestação artística, sendo que algumas puderam estudar de maneira mais específica a brincadeira, como Antropologia da Arte e Jogo Teatral 1, ou utilizar o material pesquisado para seus procedimentos didáticos, como em Organização do Trabalho Acadêmico. Coube aos docentes responsáveis pela disciplina Projetos Integradores I a organização das pesquisas, a visita aos Bois da cidade de Maceió e a recepção na Universidade dos artistas que trabalham nestes grupos, dando-lhes corpo e voz no

\footnotetext{
${ }^{33}$ Cf. nota 5.
} 
processo artístico e pedagógico e legitimando seus saberes no ambiente acadêmico. Para Richard Sennett, "como não pode haver trabalho qualificado sem padrões, é infinitamente preferível que esses padrões se encarnem num ser humano do que num código de práticas estático e sem vida" (SENNETT, 2009, p. 95).

Realiza-se, desta forma, o aprendizado do "respeito aos usos linguísticos presentes na cultura popular, refletindo sobre suas formas e usos na construção do conhecimento da comunidade" (UFAL, 2014, p. 38). E, por fim, como maneira de articular a experimentação sobre o objeto de estudo houve a construção de um exercício cênico inspirado nesses Bois. Espera-se com essa prática que o estudante adquira a habilidade para "realizar a transposição didática dos conhecimentos da arte teatral e da cultura popular brasileira para ambientes de aprendizagem formal" (p. 41).

Desta maneira, o curso de Teatro Licenciatura da UFAL indicará sempre uma expressão dramática e espetacular vinda da tradição popular alagoana para cada um dos sete Projetos Integradores presentes em sua matriz curricular com o objetivo de articular o tripé ensino-pesquisa-extensão da universidade brasileira. A função desta disciplina será, portanto, a de:

- trazer para o interior da cultura acadêmica universitária os saberes advindos da cultura de tradição popular local e seus mestres criadores, realizando a difusão desta cultura através de suas formas próprias de expressão e comunicação artística;

- levar, através de projetos e atividades de Extensão, as formas de expressão e comunicação próprias do conhecimento acadêmico até às comunidades responsáveis pela produção de manifestações espetaculares da tradição, propiciando-lhes o acesso a estes saberes universais;

- fomentar nos corpos docente e discente a pesquisa histórica, estética, pedagógica e dos processos de produção das manifestações dramáticas e espetaculares da tradição popular alagoana [p. 64].

Estamos ainda na fase de implantação do novo PPC e, portanto, tais práticas ainda precisarão ser experienciadas e experimentadas, pensadas e avaliadas, e, necessariamente, ampliadas para as atividades de extensão do curso. O registro das visitas aos locais em que se produzem essas manifestações e, principalmente, a recepção dos mestres e artistas da brincadeira dentro da universidade, dando-lhes corpo e voz e, assim, legitimando seus saberes como conhecimento acadêmico, 
com certeza se constituirá em valioso material de pesquisa, difusão e fomento das manifestações estudadas.

\subsubsection{Perspectivas e dilemas}

O novo PPC de Teatro Licenciatura aponta para alguns caminhos possíveis para se enfrentar questões que a universidade brasileira vem se colocando neste início de terceiro milênio, também presentes no Projeto Pedagógico Institucional da UFAL, como as articulações entre teoria e prática e entre ensino, pesquisa e extensão, a interdisciplinaridade e a flexibilidade curricular (UFAL, 2014, p. 16). Porém, neste caminho, divisamos uma série de dilemas a serem enfrentados.

O primeiro dilema se refere aos objetos de estudo e experimentação e às suas formas diferenciadas de produção, pois cada uma das manifestações artísticas da tradição possui suas peculiaridades e nem todas possuem um mestre que conduza e oriente as ações da comunidade, como é o caso, por exemplo, de diversos grupos de Quadrilhas juninas e de Bois alagoanos. Inseridos em uma produção voltada aos festivais competitivos e ao calendário turístico de Alagoas, estes grupos tendem a relegar muitos dos elementos tradicionais dessas manifestações artísticas para realçar inovações formais. Assim, a noção de transmissão de um saber tradicional muitas vezes é substituída pela necessidade de executar "corretamente" o que foi determinado por um artista criador.

O dilema se refere na maneira de abordar diferenças que não correspondem ao idealizado no PPC de Teatro Licenciatura da UFAL como manifestação artística da tradição popular por se inserirem nestas formas de produção mercantilizadas. Quando tentamos delimitar um território para o que entendemos como Cultura Popular de Tradição de Alagoas, talvez estejamos recriando um ideal de "pureza" presente em visões rejeitadas no próprio documento.

O segundo dilema se refere aos princípios e aos modos pedagógicos conflitantes entre as manifestações da tradição popular e as propostas da UNESCO para a educação no terceiro milênio. Um processo de ensino e aprendizagem de 
expressões artísticas oriundas da tradição popular dentro da escola formal, seja em cursos superiores, seja na Educação Básica, realizado a partir de uma perspectiva de construção do conhecimento seria uma maneira de "trair" ao próprio objeto de estudo, acolhendo suas formalizações, porém rejeitando seus modos de produção e transmissão?

Uma possibilidade para se pensar o assunto talvez seja uma pedagogia que se baseie na experiência, como defendida por Adorno (1995) e Jorge Larrosa (2014). Talvez o estudo e o experimento sobre uma matéria unidos à prática da construção de um objeto artístico, como propomos nos Projetos Integradores, possam provocar essas afecções, essas paixões que caracterizam as experiências que nos atravessam. Aliar em um processo pedagógico o fazer, o escrever, a "mão na massa", ao apreciar, ao ler, refletindo na própria ação sobre os materiais de estudo, e ainda à contextualização, ao entendimento dos sentidos desse objeto/manifestação como reflexão de mundo, pode ser um caminho para o ensino e a aprendizagem do teatro.

\subsection{Encenação como prática pedagógica na formação do Professor de Teatro}

Já escrevi alguns "poemas" sobre a encenação como prática pedagógica de iniciação teatral em projetos extracurriculares dentro do ambiente escolar, inclusive uma dissertação de mestrado. Outros já escreveram belos e consistentes "poemas" sobre o tema, tanto na formação do artista teatral como em ações socioculturais. Não caberia aqui, nesta conclusão em forma de proposições, fazer um extenso estudo sobre o tema, mas problematizar sua inserção dentro do sistema educativo, especificamente na formação do Professor de Teatro para a Educação Básica no curso de Teatro Licenciatura da Universidade Federal de Alagoas (UFAL).

Ao contrário dos Referenciais Curriculares alagoanos e do Projeto Pedagógico do Curso de Teatro Licenciatura da UFAL, formalizados em documentos oficiais, esta proposição se dá na efemeridade da cena e das aulas de teatro. Os anos que se levaram para fazê-la não se traduzem facilmente em palavras, mas em 
experiências, muitas das quais intransferíveis e dificilmente compartilháveis em um trabalho acadêmico (LARROSA, 2014). Trata-se de experiências em que as relações interpessoais são determinantes para o desenvolvimento do processo e que, portanto, não são passíveis de repetição, reprodução e de tradução em linguagem acadêmica. $\mathrm{O}$ que tentarei fazer aqui é problematizar alguns aspectos da prática da encenação dentro de uma licenciatura em Teatro que possam dialogar com as questões levantadas anteriormente nesta tese, como a formação na linguagem teatral dos futuros professores, a persistência do exercício da polivalência nas aulas de Arte na Educação Básica, a educação estética do Professor de Teatro, a construção da cena como experiência formativa coletiva e democrática, a abordagem colaborativa na criação como procedimento didático e a obra artística como matéria de estudo e aprendizagem.

\subsubsection{Alfabetização na linguagem teatral}

Tornar obrigatório o ensino da linguagem teatral como componente curricular da disciplina Arte na Educação Básica brasileira, como se apresenta no Projeto de Lei $\mathrm{n}^{\circ}$ 7032/10, do Congresso Nacional, e integra o conjunto de reivindicações formuladas pelas entidades de representação dos arte educadores para a futura Base Nacional Curricular Comum (BNCC), em fase de construção, é um primeiro passo. O que ainda não se conseguiu colocar na forma de lei é a obrigatoriedade deste componente ser ministrado por professores formados em licenciaturas em teatro como indicado pelos PCN-Arte, pois entendo que estes profissionais seriam os mais capacitados para enfrentar as diversas questões colocadas neste trabalho. Mesmo assim, hoje, na maioria dos estados do país, universidades públicas oferecem essa graduação com o intuito de suprir a demanda por esses profissionais de ensino. O que nos coloca diante de outra questão, reflexo das desigualdades econômicas e diferenças culturais entre as regiões do país aliada à precariedade do ensino de Teatro na Educação Básica: de um lado, estados e cidades que oferecem, patrocinados pelo poder público, entidades não-governamentais, escolas e outros setores ligados à iniciativa privada, apresentações de espetáculos teatrais, oficinas e 
cursos livres de iniciação à linguagem com certa regularidade e disponibilidade de vagas para um grande número de interessados, através de programas de ação sociocultural; de outro, locais sem acesso a espetáculos teatrais e sem nenhuma opção de cursos para quem queira experimentar a linguagem, o que ocorre na maior parte do território brasileiro. Neste caso, os jovens estudantes ao ingressarem nos cursos de licenciatura em teatro não conhecem necessariamente a matéria na qual pretendem se tornar docentes. A maioria desses licenciandos inicia seus estudos superiores com parcos conhecimentos teatrais, oriundos de rápidas experiências em oficinas de iniciação e com grupos amadores e estudantis ou ainda como espectadores. No caso da Universidade Federal de Alagoas é recorrente a presença no curso de Teatro Licenciatura de alunos que se apaixonaram pelo teatro ao atuarem e/ou assistirem, desde crianças, festas e apresentações religiosas como o Auto da Paixão de Cristo. Há ainda o caso da ausência completa destas experiências, limitando as ideias e (pré)conceitos sobre o teatro a outras linguagens midiáticas como a televisão e o cinema. Isabel Marques e Fábio Brazil observam que esse desconhecimento não se refere somente à linguagem teatral:

os estudantes que chegam ao primeiro ano dos Cursos Superiores de Arte muitas vezes estão totalmente desprovidos do "básico" na área de Arte: desconhecem conceitos e práticas elementares na área de atuação escolhida e têm enorme defasagem em relação às áreas teóricas de conhecimento que entrelaçam as práticas artísticas [MARQUES e BRAZIL, 2014, p. 65].

Em se tratando de uma linguagem, o restrito conhecimento de seus códigos, fundamentos, práticas e da própria gramática teatral dificulta a apropriação dessa expressão artística de maneira mais acurada, seja como espectadores, seja como atuantes. "Não raramente os Cursos Superiores de Arte têm de começar do zero, iniciar um processo de ensino e aprendizagem a partir de questões elementares", afirmam Marques e Brazil (p. 65). Se linguagem é a "capacidade humana de articular significados coletivos em sistemas arbitrários de representação, que são compartilhados" (BRASIL, 2000b, p. 5), segundo os PCN para o Ensino Médio, como alguém que desconhece os códigos de representação de uma determinada linguagem pode articulá-los e compartilhá-los produzindo sentidos coletivos? Assim, pode-se afirmar que a maioria dos ingressantes em licenciaturas teatrais, ao 
desconhecer a linguagem do teatro, é analfabeta ou semialfabetizada nesta linguagem, o que torna necessário alfabetizar os futuros alfabetizadores.

Marques e Brazil defendem que é preciso "pensar desde cedo naqueles que se tornarão artistas" (MARQUES e BRAZIL, 2014, p. 67), isto é, já na Educação Básica, argumentando que se o objetivo da escola é formar cidadãos é preciso considerar que os futuros artistas também são (serão) cidadãos (p. 72). Trata-se de posicionamento que delega à escola básica a solução de uma carência de acesso a determinadas expressões artísticas que caracteriza a formação da população brasileira, o que faz com que, mais uma vez, se espere que a escola resolva, num futuro sempre desejado e nunca alcançado, um problema que é da própria sociedade. Dentre tantas responsabilidades e problemas que a educação escolar enfrenta, cria-se outro. Uma possibilidade que se apresenta é a de que o oferecimento de oficinas de iniciação teatral no contraturno da futura escola de tempo integral possa resolver esse problema nos anos vindouros, como prevê o Plano Nacional de Educação, de 2014 (BRASIL, 2014) ${ }^{34}$. Mas como lidar com esse problema hoje, pois é neste momento que formamos o Professor de Teatro que irá atuar tanto dentro do ensino curricular como nas atividades culturais do contraturno?

Seria o caso de se pensar em mestres ignorantes, no sentido que Jacques Rancière deu aos modos pedagógicos desenvolvidos pelo educador francês Joseph Jacotot, nos anos posteriores à Revolução Francesa? Mestres emancipadores que, ao contrário dos mestres sábios e explicadores, desconhecem a matéria de estudo, mas saberiam mergulhar os alunos em uma ordem da qual eles poderiam sair sozinhos, quando se retirasse sua inteligência para deixar as deles àquelas do livro estudado (RANCIÈRE, 2010, p. 31). Parece-me que as lições de Jacotot não podem ser totalmente transpostas para o ambiente escolar e, caso pudessem, talvez não fosse recomendável desenvolver um processo educacional deste tipo em um país de território tão extenso e complexo culturalmente como o nosso, correndo o risco de, mais uma vez, transformar a escola pública brasileira em laboratório de experiências e os nossos alunos em cobaias. Mas estas lições de Rancière/Jacotot podem ser inspiradoras para nós, educadores, em alguns de seus princípios como o pressuposto da igualdade de inteligências entre mestre e educando, que aprender e

${ }^{34}$ Cf. p. $76-80$. 
compreender são duas maneiras de tradução e a necessidade de existir algo em comum entre os dois, o "livro", a coisa pela qual ambos se interessam.

\subsubsection{Encenação como operador na alfabetização na linguagem teatral}

Masschelein e Simons defendem que o "livro" não é somente um objeto de conhecimento, mas algo que nos envolve, que nos interessa, "que se torna um interesse (algo que não é nossa propriedade mas que é compartilhado entre nós)" (MASSCHELEIN e SIMONS, 2013, p. 50, grifo dos autores). Dessa maneira, o livro “não é mais um 'objeto' (inanimado) mas uma 'coisa' (viva)" (p. 50), que une professor e aluno em torno da matéria de estudo e a partir do qual se pode aferir o desenvolvimento do processo de aprendizagem e formação. O que proponho é que a "coisa" em comum em torno da qual o docente universitário e o aluno da licenciatura em teatro poderão realizar o processo de alfabetização na linguagem teatral seja a encenação.

As graduações de licenciatura em teatro procuram articular três eixos de conteúdos curriculares: os conhecimentos específicos da linguagem, os conhecimentos pedagógicos relacionados à linguagem e os conhecimentos necessários à capacitação do professor de Educação Básica. Dessa maneira, os currículos dessas licenciaturas contemplam as disciplinas que compõem o estudo da arte teatral, como a dramaturgia e seus elementos históricos, estéticos e poéticos, a atuação e os elementos que compõem o seu aprendizado como os estudos do corpo, da voz e da movimentação cênica, e os conhecimentos relacionados aos demais elementos espetaculares como cenografia, maquiagem, indumentária, iluminação e sonoplastia. Contemplam ainda disciplinas teóricas como História da Arte e do Teatro, Estética, Ética, Filosofia, Sociologia, entre outras, e disciplinas relacionadas ao exercício da docência, tanto específicos da linguagem teatral, como aqueles pertinentes ao exercício do magistério na Educação Básica. Ora, a área de estudo que pode lidar com todos esses conhecimentos como se fossem parte de um vocabulário comum e os colocar em diálogo de maneira a criar sentidos é a Encenação. Sendo a encenação uma arte de composição, esta atividade procura 
articular todos os elementos e disciplinas teatrais em um todo coerente do que se dará a ver. Começa-se, assim, pelo todo para se chegar às menores partes que compõem a linguagem teatral, tal qual Rancière e Jacotot defendem: "Toda a potência de uma língua está no todo de um livro" (RANCIĖRE, 2010, p. 47). "Começa-se pelo texto, e não pela gramática, pelas palavras inteiras e não pelas sílabas" (p. 49).

A arte da encenação como aquela que abarca o todo do teatro, portanto, do entendimento de teatro como composição através de vários elementos e disciplinas em um conjunto é recente no pensamento ocidental, o que faz Denis Guénoun observar que:

Ir ver um espetáculo é bem diferente do que era ir ver uma peça: ver uma peça era seguir uma história, situações e personagens em conflito. Ver um espetáculo é ver a teatralidade em sua operação própria: a operacionalização, o verter (a versão) no teatro, o gesto de levar para a cena uma realidade não-cênica, poema ou narrativa. Ir ver um espetáculo é exatamente ir ao encontro de uma encenação, de uma colocação no palco, de uma operação de exibição enquanto exibição, autônoma e singular em relação às entidades imaginárias cuja existência, até então reservada, ela materializa [GUÉNOUN, 2004, p. 140, grifos do autor].

Nesta perspectiva, a encenação não só se refere à arte de colocar em diálogo todos os elementos do teatro e dar-Ihes um sentido, como também à arte de quem vê (do espectador) e à arte de conduzir e orientar a atuação de todos os profissionais envolvidos na cena. Encenar como procedimento pedagógico de alfabetização na linguagem dentro de licenciaturas em teatro se torna, assim, uma maneira de lidar com os elementos que compõem a cena, de traduzir (verter) para o palco uma realidade não cênica, bem como conduzir o aprendizado das disciplinas de criação que participam do fenômeno, seja através do fazer, seja do apreciar. Ler e escrever teatro se tornam, assim, ações intrínsecas e necessárias para a construção da cena. Frise-se, dessa maneira, que a condução de um grupo de fruidores e criadores exige um olhar e uma atitude pedagógica, ou seja, o estabelecimento de uma atitude de aprendizagem das matérias estudadas e experimentadas.

Como se disse, olhar o teatro através da encenação como procedimento pedagógico é olhá-lo em seu aspecto espetacular, no qual a arte de compor os 
vários elementos plásticos e rítmicos está voltada ao que se dará a ver, ouvir e sentir pelo espectador. Para Deleuze e Guattari, composição é a própria definição de arte:

Composição, composição, eis a única definição da arte. A composição é estética, e o que não é composto não é uma obra de arte. Não confundiremos todavia a composição técnica, trabalho do material que faz frequentemente intervir a ciência (matemática, física, química, anatomia) e a composição estética, que é o trabalho da sensação. Só este último merece plenamente o nome de composição, e nunca uma obra de arte é feita por técnica ou pela técnica [DELEUZE e GUATTARI, 1992, p. 247].

Além de trabalhar sobre as poéticas relacionadas à cena e incluir a recepção como parte do teatro enquanto tal, o processo pedagógico de criação de uma encenação pode, de certa maneira, enfrentar os problemas relativos à diversidade de linguagens que compõem as aulas de Arte na Educação Básica. Se, por um lado, a atuação polivalente do professor de Arte demonstrou, por quase três décadas, que suas deficiências são maiores que seus ganhos, por outro, diante da realidade da escola brasileira, processos de formação de professores de teatro que estudem e experimentem a linguagem a partir da perspectiva da encenação pode ser uma maneira de prepará-los para uma realidade que ainda lhes exige um amplo conhecimento sobre as demais linguagens artísticas. A esse respeito vale ressaltar que o surgimento do encenador moderno está ligado às formulações de Richard Wagner e sua Gesamtkunstwerk ("obra de arte total”) ${ }^{35}$, que defendia que o espetáculo teatral deveria ser a fusão de todas as artes, e também é contemporâneo das vanguardas históricas modernistas, momento em que, segundo Ana Mae Barbosa,

Os projetos europeus em direção à "arte total" incorporavam pintura, poesia, música e dança e rejeitavam a separação das Artes em instituições que as isolassem umas das outras, como museus e teatros.

As vanguardas não só queriam transformar mas principalmente totalizar a Arte [BARBOSA, 2014, p. 17].

Talvez a questão aqui não se refira ao teatro como fusão, mas como possibilidade de composição e de diálogo entre diversas linguagens artísticas, o que caracterizaria a arte da encenação. O aprendizado da encenação pelos licenciandos em teatro possibilita, dessa maneira, a alfabetização na linguagem, as experiências

\footnotetext{
${ }^{35}$ Cf. nota 23.
} 
de fazer e de apreciar, a reflexão sobre os sentidos do que se faz, o trânsito por entre outras linguagens artísticas e a experiência com modalidades pedagógicas que podem ser transpostas para a Educação Básica. Marcos Bulhões Martins defende inclusive que saber encenar deve fazer parte das competências artísticas e pedagógicas do Professor de Teatro que atua no âmbito das ações socioculturais:

consideramos que uma das opções para a formação do professor de teatro é a perspectiva do mestre-encenador, entendido aqui como aquele que busca realizar a representação sem quebrar a continuidade da oficina, mantendo o caráter coletivo do trabalho e o respeito ao grupo [MARTINS, 2002, p. 242].

Ressalte-se, por fim, que a encenação aqui não é vista em seu caráter de produto final de um processo artístico e pedagógico em teatro, tal qual propõem as "pedagogias da espetacularidade", mas como parte desse processo. No caso do teatro, a própria ideia de "produto final" submete-se à efemeridade característica das artes presenciais, como observam Isabel Marques e Fábio Brazil:

No caso das artes de performance (dança, teatro, música), o produto compartilhado mobiliza-se e é recriado justamente em função do encontro com os espectadores. [...] Ou seja, produto finalizado não precisa ser visto como sinônimo de produto final. Finalizar um produto não precisa ser sinônimo de acabar, de terminar, de cristalizar a finalização e o contato com o público poderiam ser vistos como estar pronto para iniciar um novo e extraordinário processo de transformação [MARQUES e BRAZIL, 2014, p. 94].

Pedagogicamente, na alfabetização dos futuros professores de teatro interessam mais as possibilidades de articulação entre o fazer, o apreciar e o refletir sobre o objeto do que o produto artístico final, que talvez nunca se concretize como tal, cristalizado, pois as necessárias apresentações para espectadores externos ao processo sempre possibilitam retomadas do trabalho. O estudo, a experimentação e a constante recriação da cena realçam o caráter de working in progress, "no qual o paralelismo entre o processo e o produto são matrizes constitutivas da linguagem" (COHEN, 1997, p. 2), tornando leitura, reflexão e retomada de materiais ações intrínsecas à aprendizagem e à formação artística, e estas são sempre inconclusas, pois em constante movimento. Trata-se sempre, na perspectiva de Jean-François Lyotard sobre a pós-modernidade, de novos lances à procura do consenso, que se configura como um horizonte inatingível (LYOTARD, 2006, p. 112). O produto 
apresentado publicamente surge como consequência do processo pedagógico e não como orientador desse processo. Tal sentido é assim expresso pelos integrantes da Cia. de Teatro Balagan:

Não perseguimos uma ideia de espetáculo, mas, ao contrário, almejamos que a sua construção - a partir do incerto, da experimentação, do estudo das reverberações do tema nas mais diversas áreas e do reconhecimento dos seus ecos no mundo - crie o que é comum.

O processo, aquilo que é comum, é o que se toma parte, que se compartilha, que dá a noção de pertencimento e os conforma enquanto coletivo artístico [SAYAD et all., 2014b, s/p., grifos dos autores].

Aqui o caminho é muito mais importante do que o destino, ainda que chegar a algum lugar seja fundamental. A formalização dos elementos que compõem a cena, sua composição em um todo coerente e as apresentações públicas de encenações, vistas como "produto final", são parte fundamental do teatro como tal. Joaquim Gama afirma que "não se trata de optar pela primazia do processo em detrimento do produto ou vice-versa, e sim pela escolha de métodos que favoreçam a construção do conhecimento teatral dentro de parâmetros educacionais claros, participativos e criativos" (GAMA, 2002, p. 269, grifo do autor). Assim, a produção do espetáculo torna-se parte inerente do processo de aprendizagem da linguagem teatral bem como sua apresentação, pois sendo o teatro em sua natureza uma arte efêmera e presencial, o encontro com o espectador em evento público torna-se condição para sua existência. Nas palavras de Deleuze e Guattari, "talvez seja próprio da arte passar pelo finito para reencontrar e restituir o infinito" (DELEUZE e GUATARI, 1992, p. 253).

\subsubsection{Encenação como ação pedagógica}

A origem da encenação moderna, em fins do século XIX, na Europa, que provocou a autonomia da figura do encenador dentro da criação teatral, carrega em si fortes conotações pedagógicas, seja visando o espectador, seja voltando-se à formação dos artistas teatrais. Pode-se observar essa tendência pedagógica na trajetória de diversos encenadores que desenvolveram processos de criação que 
necessitavam, antes de tudo, da formação de novos artistas e novas formas de ler o fenômeno teatral.

Historicamente, o entendimento de teatro no ocidente traduziu-se, com variações de ênfase, em literatura dramática e na arte do ator, como o estudo de Courtney (2003) demonstra ao analisar as perspectivas filosóficas a cerca dos efeitos educativos desta arte, ora através do espetáculo e da atuação dos atores, ora do texto dramático. A encenação, segundo Patrice Pavis, "se assemelhava a uma técnica rudimentar de marcação dos atores" (PAVIS, 1999, p. 122), que ficava a cargo do ensaiador ou do ator principal, que procuravam "fundir o espetáculo num molde preexistente" (p. 122), seja através de indicações dramatúrgicas dos autores do texto, que poderiam estar explicitadas nas didascálias ou implícitas nos diálogos das personagens, seja através da própria arte dos atores através do domínio técnico de movimentações e coreografias. A forma como o espetáculo teatral se dava a ver ao público (cenários, figurinos, músicas) dependia do contexto no qual o fenômeno estava inserido, pois cada época e cada lugar produziram formas espetaculares específicas.

Essa tradição iria sofrer uma ruptura em finais do século XIX. Como observa Jorge Coli, "o 'em si' da obra de arte [...] não é uma imanência, é uma projeção. Somos nós que enunciamos o 'em si' da arte, aquilo que nos objetos é, para nós, arte" (COLI, 1995, p. 64]. O "em si" do teatro, a ideia do que hoje chamamos de teatro começa a se modificar quando é criada a companhia teatral da corte do duque de Meiningen, na Alemanha, em 1866, que introduz elementos cenográficos e de figurinos com o objetivo de dar veracidade histórica a suas representações. Segundo Anatol Rosenfeld, "o êxito foi impressionante em consequência da rigorosa execução de um lema fundamental: subordinar tudo às intenções do poeta, realizando-as com o emprego de todos os meios da arte de representar e da técnica cênica" (ROSENFELD, 2000, p. 101). O entendimento do que é teatro volta a se alargar, reincorporando à literatura dramática e à arte do ator, as artes plásticas e as artes temporais da cena em um conjunto integrador e composto, a encenação. $O$ sucesso em palcos do continente europeu dos Meininger, a partir de 1874, também foi um dos responsáveis pelo retorno a uma tradição que remonta às primeiras trupes de commedia dell'arte italiana, o sentido de ensemble, de conjunto, há muito relegado 
ao segundo plano pelo teatro realizado pelos grandes atores da época, em torno dos quais se organizava toda a estrutura cênica. Anatol Rosenfeld vê na "supressão rigorosa do virtuosismo de determinados atores e atrizes, dominante em muitos palcos desde o Renascimento" (p. 101), como a segunda renovação dos Meininger: "Todos os atores tinham de servir com lealdade e abnegação, dentro do conjunto, à perfeita apresentação da obra-total - fruto de uma unidade completa de poesia, representação, encenação, décor etc." (p. 101). A associação entre o desejo de fidelidade à obra dramática na busca por uma unidade estética para o espetáculo teatral ao sentido de trabalho em grupo, somados ainda aos avanços tecnológicos que auxiliaram na mecanização do palco e no aperfeiçoamento da iluminação elétrica irão influenciar decisivamente os jovens encenadores europeus. Assim, segundo Jean-Jacques Roubine, a encenação firma-se como arte autônoma nas três últimas décadas do século XIX, convencionando-se "adotar como ponto de partida o ano de 1887, quando [André] Antoine fundou o Théâtre-Libre" (ROUBINE, 1998, p. 14).

Denis Guénoun, por sua vez, vê no surgimento do encenador moderno uma reação do teatro diante da invenção do cinema desprezando o fato de que existe um período de tempo considerável entre a invenção e a popularização deste invento pela Europa, o que colocaria em questão esse paralelismo histórico. Porém, as relações que este filósofo francês estabelece entre o espectador de teatro e o de cinema podem ser elucidativas para se compreender o crescimento da influência do encenador no teatro do século XX. Segundo Guénoun, o cinema "dá ao imaginário uma existência efetiva, a existência das imagens. [...] O cinema realiza o imaginário em imagens" (GUÉNOUN, 2004, p. 102, grifos do autor). Dessa maneira, "o imaginário teatral se põe assim sob a autoridade do modelo cinematográfico. De certo modo, ele se rende ao cinema" (p. 112, grifo do autor), o que faz com que os artistas teatrais procurem incorporar esse novo espectador cinematográfico através da arte da encenação:

O encenador é a realização da ideologia do teatro. E não consideramos fortuito o fato de que o surgimento do encenador, como ofício independente, função estética específica, seja exatamente contemporâneo da invenção do cinema. Porque o encenador tenta produzir no teatro uma posição que está se inventando a seu lado, no cinema, calmamente e para sempre: a posição do sujeito transcendental da representação. É que o cinema roubou do teatro seu espectador imaginário. Dando- 
Ihe seu estatuto, sua existência, sua autonomia: na imagem. Mas na imagem realizada [p. 119, grifo do autor].

Desejosos de criar um novo teatro no qual o espetáculo se configurasse em um todo harmônico, os jovens encenadores precisaram romper com o teatro feito até então, ultrapassando e englobando "a soma dos materiais ou artes cênicas, outrora considerados como unidades fundamentais" (PAVIS, 1999, p. 123). Para Edward Gordon Craig, "uma obra de arte não pode ser criada se não for dirigida por um pensamento único" (CRAIG apud PAVIS, 1999, p. 123), justificando a autonomia do encenador perante o que se dará a ver. Assim como parte dos artistas modernistas, para criar as novas formas foi preciso também educar o olhar do espectador para esse novo. Foi o que fizeram E. G. Craig, André Antoine, Constantin Stanislavski, Vsevolod Meierhold, entre tantos, produzindo numerosos estudos em que apresentavam suas perspectivas sobre o teatro, a encenação e a arte do ator, e difundiam seus experimentos cênicos numa espécie de "educação do olhar" voltada aos espectadores, aos críticos teatrais e aos seus próprios pares. Tal procedimento pedagógico em tornar público pensamentos e procedimentos artísticos era comum entre os modernistas, como foi o caso de, por exemplo, Malevitch, Klee, Schoemberg, Einseinstein, Mario de Andrade, Ezra Pound, dentre tantos. Observese que artistas pedagogos e fundadores de novos paradigmas críticos não é exclusividade do modernismo, pois em outros momentos históricos houve aqueles artistas que produziram materiais de reflexão sobre a arte, como Diderot, Göethe, Schiller, Zola, Victor Hugo. Configurava-se em uma tentativa de estabelecer outras formas de diálogo, para além da obra artística, com a crítica da época, nas quais os próprios artistas assumiram posicionamentos críticos diante de suas obras buscando formar um novo olhar para suas criações. O que pode se configurar como um diferencial dos modernistas é que a questão da pedagogia e do estabelecimento de novos padrões estéticos avaliativos para a arte é parte estrutural de seu projeto, inclusive em seus aspectos éticos e políticos, nos quais se lutava por uma nova sociedade e um novo homem.

Assim, segundo Maria Thaís, "é no advento da modernidade que emerge a presença do encenador como mediador entre a técnica e a totalidade da representação teatral, ou seja, como responsável pela codificação do espetáculo e 
por propiciar os meios de formação dos seus intérpretes" (THAís, 2009, p. 72). Fabrízio Cruciani observa que as transformações provocadas no teatro por estes mestres da encenação se deram a partir de suas perspectivas pedagógicas:

As práticas e as poéticas dos grandes mestres conduziram a uma espécie diferente de teatro. O elemento essencial: a pedagogia, a procura pela formação de um novo ser humano num teatro e sociedade diferentes e renovados, a procura por um modo de trabalho que possa manter uma qualidade original e cujos valores não são medidos pelo êxito dos espetáculos, mas sim pelas tensões culturais que o teatro provoca e define [CRUCIANI apud MARTINS, 2004, p. 39].

O rompimento não seria somente estético, mas na própria forma de produção, pois o sentido de conjunto (ensemble) torna-se, muitas vezes, condição necessária para a concretização desse "novo teatro". No caso de uma arte coletiva como é o teatro, além de educar o olhar do espectador, os encenadores precisavam também se fazer entender por aqueles que iriam participar na criação dessas obras (atores, cenógrafos, figurinistas, músicos, iluminadores). Maria Thaís detecta aí, através dos dilemas enfrentados por Meierhold diante da formação dos atores de seu tempo, uma diferenciação entre o "encenador como maestro de uma orquestra" do encenador-pedagogo: "ao delimitar o campo do encenador como regente da cena, Meierhold deparou-se uma vez mais com a questão do ator. [...] O novo teatro exigia que se renovassem os meios e procedimentos técnicos daquele que materializava, no tempo e no espaço, as ideias do encenador" (THAís, 2009, p. 26).

Neste sentido, muitos dos jovens encenadores irão atuar diretamente na formação técnica e poética dos integrantes de seus grupos, pois seus processos de construção da obra espetacular passavam pela necessária formação do artista da cena. Maria Lúcia Pupo observa que pedagogia e criação eram processos intrínsecos a esses encenadores:

De modo radical eles sempre associaram a depuração de sua arte ao desenvolvimento pessoal daqueles que a praticam. Para eles a superação de si mesmo se coloca como uma meta inseparável da realização de um teatro que transcenda códigos já consagrados. Preceitos de caráter ético sempre acompanharam seu projeto de renovação teatral [PUPO, 2001, p. 33].

A criação e o aprendizado das novas formas desejadas aconteciam simultânea e intrinsecamente, influenciando-se reciprocamente. O processo coletivo 
propiciava o surgimento de diversas vozes criativas na construção do espetáculo, vozes que eram organizadas e colocadas em cena pelo encenador.

A prática pedagógica denunciou a eficácia de determinados princípios em detrimento de outros, e exigiu uma seleção objetiva que permitisse, além de promover a formação do ator, educá-lo também para educar a plateia. A prática cênica, a encenação, era o único método seguro de ensino rumo ao novo teatro [THAís, 2009, p. 99],

observa Maria Thaís a respeito dos anos de formação de Meierhold como encenador. Assim, se por um lado o encenador é o "espectador que atuava", nas palavras de Guénoun, organizando o material que se dá a ver, por outro também é o pedagogo que orienta os experimentos do grupo, configurando-se uma duplicidade de funções na qual reconhecemos a figura do encenador-pedagogo. Pois é claro que somente a presença de um encenador não garante que o processo formativo dos participantes seja emancipatório, é necessário que a perspectiva pedagógica seja intrínseca ao trabalho de pesquisa e criação. Marcos Bulhões Martins, ao se referir a encenadores brasileiros como Augusto Boal, José Celso Martinez Corrêa e Antunes Filho, observa que

Para eles, a pedagogia não é uma atividade "paralela" à prática cênica, mas sim, uma necessidade inerente à sua atuação. Cada espetáculo destes diretores impõe problemas diferentes, gerando um programa de trabalho particular, considerado como um elemento capaz de fazer progredir a linguagem cênica [MARTINS, 2004, p. 41].

É o que se depreende dos estudos desenvolvidos por Meierhold acerca do espectador, a quem ele chamava de "quarto criador". O encenador russo distinguia dois "métodos na arte da direção" antagônicos, sendo que no primeiro o encenador assume uma posição hierárquica superior mediando a recepção do espectador a partir da criação do ator e do dramaturgo e, assim, inibindo a liberdade de criação tanto do ator como do espectador. No segundo método, Meierhold desenha uma flecha horizontal que passa por quatro pontos, criando, segundo Maria Thaís,

uma estrutura em que todos são proponentes, em um processo de assimilação e provocação contínua: do autor para o encenador, deste para o ator e, finalmente, do ator para o espectador, acentuando assim a ação recíproca dos dois elementos fundamentais do teatro - comediante e espectador [THAíS, 2009, p. 39). 
A partir deste segundo método na arte da direção proposto por Meierhold, os integrantes da Cia. Balagan observam: "No esquema da flecha percebemos profundidade e soma polifônica, a permitir, dessa maneira, espaços ou campos de reflexão para que o espectador construa seus próprios sentidos, de modo a acrescentar à obra seu olhar singular, inimitável" (MACHADO e THAíS, 2014, s/p., grifos dos autores). A abertura de espaços para a criação, seja dos atores, seja dos espectadores, é condição para que se estabeleça uma educação emancipatória e para que o processo seja interessante, instigante e, por conseguinte, formativo, colocando em diálogo as diversas vozes da criação. Para Rancière, é necessário que os espectadores "desempenhem o papel de intérpretes ativos, que elaborem sua própria tradução para apropriar-se da 'história' e fazer dela sua própria história. Uma comunidade emancipada é uma comunidade de narradores e tradutores" (RANCIĖRE, 2012, p. 25). Ou, como escreveram os integrantes da Cia. Balagan, "se o espectador é convocado a ser co-autor da obra de arte, ele é, simultaneamente, convocado a ser também autor de si mesmo" (BALAGAN, 2012b, p. 6).

\subsubsection{Uma abordagem metodológica: a encenação colaborativa}

A duplicidade de funções exercida pelo encenador-pedagogo pode ser transposta para o processo de alfabetização teatral dos futuros professores de teatro e ainda servir-Ihes como modelo para sua própria atuação profissional. Por um lado, desenvolve a capacidade de leitura da obra, decodificando os diversos elementos e colocando-os em diálogo criativo. Por outro, desenvolve a capacidade de fazer, de criar a obra, de traduzir um material não-cênico em teatro, operando com os elementos que compõem a cena sob uma perspectiva que busca uma unidade espetacular. O "livro" em torno do qual docente e licenciandos se reúnem tanto pode ser a encenação em si, como os materiais de pesquisa e experimentação para sua criação. O interesse coletivo despertado pelo envolvimento do grupo na construção da encenação pode, assim, agir diretamente na formação do Professor de Teatro.

Marcos Bulhões Martins defende, inclusive, que essa duplicidade de funções deva ser vista em uma perspectiva unitária integrando-se encenação e pedagogia do 
teatro. $\mathrm{O}$ pesquisador cita a análise realizada por Monique Borie sobre essa forma de operar nos trabalhos cênicos de Jerzy Grotovski e Eugênio Barba:

É impossível distinguir o encenador do pedagogo. [...] Não existe um vai e vem ou tensão entre as duas funções, de circulação entre dois papéis. A encenação na sua essência é fundada sobre a relação pedagógica. Mais: esta relação pedagógica define de algum modo o próprio ato de fazer teatro, tanto quanto a preparação para este ato [BORIE apud MARTINS, 2004, p. 42].

As relações que se estabelecem entre encenador-pedagogo com os demais artistas do grupo e com os espectadores também podem ser inspiradoras para processos de formação do Professor de Teatro. Ao se colocar no papel de formador, este encenador considera a criação do espetáculo como uma ação conjunta, na qual diversas vozes atuam para um último criador, o espectador. A igualdade de inteligências e de capacidades de traduzir em teatro materiais não-cênicos que se estabelece dentro dos processos de criação da encenação são similares às proposições de Rancière e de Jacotot, nas quais a igualdade é tida como princípio do processo pedagógico e não como fim: "Quem estabelece a igualdade como objetivo a ser atingido, a partir da situação de desigualdade, de fato a posterga até o infinito. A igualdade jamais vem após, como resultado a ser atingido. Ela deve sempre ser colocada antes" (RANCIĖRE, 2010, p. 11). O princípio da igualdade também procura deixar fora dos processos educativos conceitos, preconceitos e pressupostos externos ao ambiente escolar, como a ideia de talento artístico, seja ele tido como existente ou a desenvolver, como observam Masschelein e Simons:

A escola [...] surge como materialização concreta do tempo que, literalmente, separa ou retira os alunos para fora da (desigual) ordem social e econômica (a ordem da família, mas também a ordem da sociedade como um todo) e para dentro do luxo de um tempo igualitário. [...] Isto significa que este - e não, por exemplo, a transferência de conhecimento ou o desenvolvimento de talentos - é a forma de tempo livre por meio do qual os alunos poderiam ser retirados de sua posição social [MASSCHELEIN e SIMONS, 2014, p. 29].

Assim, a encenação como processo de aprendizagem da linguagem teatral deve enfatizar seu caráter pedagógico através de procedimentos que privilegiem a atuação emancipada de todos envolvidos em sua construção, levando em consideração o caráter coletivo da arte teatral e propiciando novos "lances" no quadro das regras estabelecidas, como diria Lyotard: 
A ênfase deve ser colocada de agora em diante sobre o dissentimento. O consenso é um horizonte, jamais ele é atingido. [...] É preciso supor um poder que desestabilize as capacidades de explicar e que se manifeste pela regulamentação de novas normas de inteligência ou, se se prefere, pela proposição de novas regras para o jogo de linguagem científico, que irão circunscrever um novo campo de pesquisa [LYOTARD, 2006, p. 112].

O "livro-encenação" torna-se a coisa a ser aprendida e compreendida a partir de uma perspectiva de igualdade das inteligências, sem a necessidade de explicações totalizadoras, sem ansiar pela unidade e pelo consenso, mas aberto para a multiplicidade de olhares e de traduções. É a coisa em comum, objeto de interesse entre professor e aluno, mestre e aprendiz, docente e licenciando, encenador e atuante. Fernando Pessoa, através de seu heterônimo Alberto Caeiro, traduz em poema esse processo de aprendizagem:

Sou um guardador de rebanhos

O rebanho é os meus pensamentos

E meus pensamentos são todos sensações.

Penso com os olhos e com os ouvidos

E com as mãos e os pés

E com o nariz e a boca [PESSOA, 2001, p. 44].

Essa primeira estrofe do poema $O$ Guardador de Rebanhos foi utilizada como mote pela pesquisadora francesa Marie-Madeleine Mervant-Roux, em curso ministrado na pós-graduação da ECA-USP, no ano de 2013, para desenvolver suas reflexões em relação ao espectador teatral. Se formos além desta estrofe e adentrarmos a segunda, veríamos como o poeta nos "ensina" a usar estes "instrumentos" do pensamento: "Pensar uma flor é vê-la e cheirá-la/E comer um fruto é saber-Ihe o sentido" (p. 44). Alberto Caeiro, o mestre de Fernando Pessoa, segundo o próprio poeta, ensina que o sentido das coisas só pode ser apreendido no contato com as próprias coisas, seja distanciado, olhando, vendo e cheirando, seja direto, pegando e comendo. Não há a necessidade de um "mediador de inteligências" ou de um explicador. A explicação já é outra coisa e não o que se deseja compreender. Estabelece-se uma relação de dominação da vontade do mestre, no caso, Alberto Caeiro, sobre a vontade do aluno, nós, os leitores, ou seja, a vontade de ensinar sobre a vontade de aprender, que tem, por consequência, "uma relação inteiramente livre da inteligência do aluno com aquela do livro - 
inteligência do livro que [é], também, a coisa comum, o laço intelectual igualitário entre o mestre e o aluno." [RANCIÈRE, 2010, p. 31]. A coisa em si é o "livro", o objeto que une mestre e educando e através do qual o aluno tem acesso ao mundo. É no distanciamento e na aproximação, no ver e no comer, no ir e vir entre palco e plateia, atuando e assistindo, que se dá a apreensão da linguagem teatral; entre o escrever e o ler se realiza a alfabetização.

O poema de Alberto Caeiro procura também precisar a forma de operar o conhecimento ao afirmar que seus "pensamentos são todos sensações", assim como é o pensamento das artes, segundo Deleuze e Guattari: "a composição estética [...] é o trabalho da sensação" (DELEUZE e GUATTARI, 1992, p. 247). O mundo é apreendido e pensado por sensações, pois

só há um plano único, no sentido em que a arte não comporta outro plano diferente do da composição estética: o plano técnico, com efeito, é necessariamente recoberto ou absorvido pelo plano de composição estética. É sob esta condição que a matéria se torna expressiva: o composto de sensações se realiza no material, ou o material entra no composto, mas sempre de modo a se situar sobre um plano de composição propriamente estético [p. 251].

Nesse processo pedagógico, o plano da composição estética coincide com o plano da aprendizagem, ou melhor, ambos tendem a ser o mesmo, pois, como disse Jorge Coli, "o objeto artístico traz em si, habilmente organizados, os meios de despertar em nós, em nossas emoções e razão, reações culturalmente ricas, que aguçam os instrumentos dos quais nos servimos para apreender o mundo que nos rodeia" (COLI, 1995, p. 109). O docente encenador age como sujeito emancipado e emancipador, assumindo como princípio norteador que todos os integrantes do grupo têm a capacidade de propor e pensar a cena pois todos são capazes de sentir/pensar a matéria e traduzi-la em teatro (teatralizá-la), realizando a composição.

Em minha prática docente na universidade venho adotando como modelo de abordagem pedagógica para o estudo e a experimentação da encenação um procedimento muito utilizado nos processos criativos de alguns grupos de teatro brasileiros, o processo colaborativo. Se inicialmente esse procedimento coletivo se direcionava para a construção da dramaturgia, como observam Luís Alberto de 
Abreu (2003, 2006), Antonio de Araújo Silva (2002, 2008) e Adélia Nicolete (2005), aos poucos foi ganhando espaço na criação dos demais elementos da cena dentro dos coletivos teatrais, como aponta Stela Fischer (2010). Particularmente, minha primeira experiência com procedimentos colaborativos foi decisiva para que os adotasse em práticas docentes, sendo que ela ocorreu antes mesmo da criação do termo, quando ainda era aluno do Bacharelado em Interpretação Teatral, na ECA USP, em 1989. Refiro-me à montagem do espetáculo $A$ Missão, com texto de Heiner Müller e direção do professor Marcio Aurelio, na qual o processo de criação da encenação se deu a partir de procedimentos que posteriormente seriam associados aos processos colaborativos.

Frise-se que a utilização desse modelo necessita de uma "transposição didática", diversas vezes abordada neste trabalho, de procedimentos desenvolvidos no âmbito da produção artística enquanto ofício, ainda que com fortes traços pedagógicos, para um local de formação de pedagogos, ainda que através da produção artística. Trata-se, no caso, de profanar procedimentos do que é chamado processo colaborativo visando a formação do Professor de Teatro. Para Masschelein e Simons,

o importante aqui é, precisamente, que por transformar alguma coisa em jogo, está, simultaneamente, sendo oferecida para o uso livre e novo. Está sendo solta e colocada sobre a mesa. Ou seja, algo (um texto, uma ação) está sendo oferecido e se torna, ao mesmo tempo, separado de sua função e importância na ordem social, algo que aparece em si mesmo, como um objeto de estudo e de prática, independentemente do seu uso adequado (em casa ou na sociedade, fora da escola). Quando se torna objeto de estudo ou de prática, isso significa que exige a nossa atenção; que nos convida a explorá-lo e engajá-lo, independentemente de como ele possa ser colocado em uso [MASSCHELEIN e SIMONS, 2013, p. 42, grifo dos autores].

Stela Fischer observa que o termo processo colaborativo em seu âmbito de origem, os grupos de teatro, não possui uma definição conceitual concreta nem um método preciso ou fixo, porém não deixa de propor-Ihe alguns parâmetros:

Conceitualmente, entende-se por processo colaborativo o procedimento de grupo que integra a ação direta entre ator, diretor, dramaturgo e demais artistas, sob uma perspectiva democrática ao considerar o coletivo como principal agente de criação e aglutinação de seus integrantes. Essa dinâmica propõe um esmaecimento das formas hierárquicas de organização teatral, embora com imprescindível delimitação de áreas de trabalho e delegação de profissionais que as representam. Ao estabelecer um 
organismo no qual todos os responsáveis pelos diversos campos partilham de um plano de ação comum, o trabalho em equipe baseia-se no princípio de que todos têm o direito e o dever de contribuir com a finalidade artística e a manutenção das equipes de trabalho. Seu caráter processual delega à obra uma moldagem que vai se desenhando conforme a sua colaboração em conjunto, a partir do cruzamento das diferentes áreas, desde o momento inicial até o encerramento das apresentações, considerando também o público como colaborador desse processo complexo coletivo e aberto [FISCHER, 2010, p. 61].

Quando da transposição do processo colaborativo para o âmbito universitário na formação do Professor de Teatro é preciso considerar que todas as funções descritas serão experimentadas por todos os integrantes da turma, ainda que o exercício da direção seja, normalmente, assumido pelo docente e as demais funções sejam intercambiadas pelos alunos. Neste caso, a necessária "delimitação de área de trabalho" passa a referir-se a atuação do docente como condutor do processo pedagógico, que estabelecerá o "plano de ação comum", ainda que esse papel também possa ser experimentado pelos alunos em momentos específicos, como a condução de um experimento, por exemplo. Trata-se da submissão da vontade do aluno à vontade do docente, nos termos de Rancière (2010), ou seja, "forçar uma capacidade que se ignora ou se denega a se reconhecer e a desenvolver todas as consequências desse reconhecimento" (RANCIĖRE, 2010, p. 12).

Fischer refere-se também a um "esmaecimento das formas hierárquicas da organização teatral" a partir das reflexões que Antonio Araújo realizou em torno dos processos colaborativos desenvolvidos no grupo Teatro da Vertigem, de São Paulo:

Acreditamos que melhor do que "ausência" de hierarquias, seja mais apropriado pensarmos em hierarquias momentâneas ou flutuantes, localizadas, por algum momento, em um determinado polo da criação (dramaturgia, encenação, interpretação, etc.) para então, no momento seguinte, se mover rumo a outro vértice artístico [ARAÚJO apud FISCHER, 2010, p. 157].

É preciso considerar que essas "hierarquias flutuantes" de que fala Araújo se relacionam ao fazer artístico e que no caso da transposição para ambientes educativos é preciso que se reconheça uma autoridade na figura do docente, a quem cabe organizar e orientar o processo pedagógico. Autoridade no sentido que Ihe dá Hannah Arendt em sua perspectiva educacional: "A autoridade do professor consiste em conhecer o mundo e ser capaz de instruir os outros acerca deste, porém 
sua autoridade se assenta na responsabilidade que ele assume por este mundo" (ARENDT, 2011, p. 239). É ele o mestre emancipador, com sua "responsabilidade pelo mundo", cuja "vontade" de ensinar submeterá a "vontade" de aprender dos alunos, direcionando-a à inteligência contida no "livro", ou seja, no processo de criação da encenação. Inteligência que não deve ser confundida com a própria ciência do mestre, na perspectiva de Rancière:

No ato de ensinar e aprender, há duas vontades e duas inteligências. Chamar-se-á embrutecimento à sua coincidência. [...] Chamar-se-á emancipação à diferença conhecida e mantida entre as duas relações, o ato de uma inteligência que não obedece senão a ela mesma, ainda que a vontade obedeça a uma outra vontade [RANCIÈRE, 2010, p. 31].

Se no âmbito do ofício "não há um criador epicêntrico para onde tudo convirja, mas um conjunto de criadores que vão definindo, coletivamente, os rumos, os conceitos, as práticas e as materializações de sua obra/processo" (ARAÚJO apud FISCHER, 2010, p. 75), conforme as palavras de Antonio Araújo, no âmbito educativo é preciso que haja uma espécie de "vontade epicêntrica" do docente que possa orientar a "vontade" dos alunos em aprender. Os alunos assumem, em princípio, o papel de atores: "O ator não é só o executor dessa matéria (espetacular). Isso Ihe dá uma autonomia porque detém todo o modo de produção da cena" (FISCHER, 2010, p.111), na perspectiva que Márcio Marciano, fundador da Cia. do Latão (SP) e do Coletivo de Teatro Alfenim (PB), dá a essa função dentro de um processo colaborativo. O que faz Fischer concluir que "aqui reside o principal mote sobre o qual o trabalho do ator de processos colaborativos e coletivos deve se orientar: a autonomia criativa para decidir os modos de produção da cena" (p. 111).

Observe-se que esta autonomia do ator diante da cena fez parte da tradição do teatro ocidental, paradoxalmente, até o surgimento do encenador moderno, que passou a catalisar toda a responsabilidade pela encenação. Porém, já nos primórdios desse "novo teatro", encenadores como Stanislavski e Meierhold preocupavam-se em resguardar essa autonomia fundamental para que ocorresse a comunicação entre palco e plateia. Maria Thaís afirma que Meierhold, "nesta nova relação (diretor-pedagogo-ator), aspirava ter o ator não como simples intérprete das ideias do diretor, mas como colaborador, criador, tomando para si a 
responsabilidade de prepará-lo" (THAís, 2009, p. 28). Assim, ao aproximar a atuação do ator de grupos de teatro a dos alunos em formação, o que me interessa nos processos colaborativos de encenação como procedimento pedagógico na formação do Professor de Teatro não é somente a autonomia do aluno como ator, mas a aquisição de uma autonomia em todo o processo de produção teatral, passando por todos os papéis aí envolvidos, como Fischer detecta nas criações do grupo Tribo de Atuadores Ói Nóis Aqui Traveis (RS):

Os atores/atuadores do grupo [Ói Nóis Aqui Traveiz] são autogestores e se apropriam das diferentes funções de uma produção cênica. Essa qualidade instrumentaliza o ator e amplia as possibilidades de criação do ato cênico. Dessa forma, o atuador não encerra uma única função na criação, mas aprende a manusear outras linguagens que auxiliam na criação do espetáculo, em sua totalidade, incluindo a direção [FISCHER, 2010, p. 222].

Dessa maneira, a construção da encenação torna-se uma realização coletiva, através de múltiplos olhares sobre a matéria e sobre o mundo traduzidos em múltiplas vozes que formarão uma obra de arte polifônica, que não se restringe às individualidades criadoras, mas que só se constitui como obra a partir dessas individualidades. Tal conceito de polifonia é apresentado pelos integrantes da Cia. de Teatro Balagan, a partir das reflexões estéticas de Mikhail Bakhtin, como "espaço onde convivem vozes díspares, sem a predominância de um sobre o outro, sem síntese" (SAYAD, 2014a, s/p.). Nas encenações de Meierhold, "o princípio da polifonia teatral, no qual os elementos que compunham a cena perdiam sua função ilustrativa e ganhavam autonomia, podendo inclusive divergir" (THAís, 2009, p. 154, grifo da autora), torna-se, de certa maneira, uma reação à Gesamtkunstwerk proposta por Richard Wagner, que pretendia fundir todas as linguagens cênicas para criar uma unidade espetacular. Maria Thaís observa que "a influência de Richard Wagner na Rússia se fez sentir desde o início do século [XX], na medida em que o desenvolvimento da arte da encenação aprofundou a unidade do espetáculo, pressupondo uma relação de interdependência entre todos os seus componentes" (THAís, 2009, p. 48). O princípio de encenação como obra polifônica em contraposição à Gesamtkunstwerk wagneriana irá influenciar o posicionamento político e estético de outro grande encenador-pedagogo, Bertolt Brecht, 
Há, pois, que intimar todas as artes afins da arte dramática a não produzirem uma "obra de arte global" (Gesamtkunstwerk), na qual todas renunciam a si próprias e se percam, mas, sim, a promoverem, nas suas diversas formas, em conjunto com a arte dramática, uma missão comum. As relações que devem manter entre si consistem em se distanciarem reciprocamente [BRECHT, 1978, p. 133].

Dessa maneira, a "noção de polifonia é mola mestra na estrutura imaginada para se criarem os espetáculos colaborativos" (SAYAD, 2014a, s/p.). Fischer observa, porém, que "cada processo criativo e cada dinâmica interna de organização de companhias que se utilizam desse procedimento têm suas particularidades" (FISCHER, 2010, p. 159), sendo que o que interessa a esse estudo é o procedimento de trânsito dos estudantes/atuantes pelos diversos papéis que compõem a criação da encenação. Tal qual acontece no Jogo com a Peça Didática, de Brecht, e no Teatro do Oprimido, de Augusto Boal, a "troca de papéis" é condição para o aprendizado e para a alfabetização teatral, porém aqui essa troca envolve todos os elementos da cena de forma com que todos os integrantes do grupo possam participar e agir sobre o todo e sobre suas partes. Bertolt Brecht exemplifica essa maneira de proceder do encenador:

Entre nós o encenador não penetra no teatro com sua 'ideia' ou sua 'visão', uma 'planta baixa das marcações' e dos cenários prontos. Seu desejo não é 'realizar' uma ideia. Sua tarefa consiste em despertar e organizar a atividade produtiva dos atores (músicos, pintores, etc.). Para ele, ensaiar não significa fazer engolir a força alguma concepção fixada a priori em sua cabeça e, sim, pô-la à prova [BRECHT apud PAVIS, 1999, p. 125].

O que faz com que a matéria de aprendizado torne-se comum a todos, seja profanada, compartilhada, democratizada e socializada durante o processo de construção da cena. O processo de aprendizado é realizado através do dissenso, desestabilizando a capacidade de explicação e realçando as sensações no plano da composição. Ressalte-se, portanto, que dissenso aqui não é conflito de ideias e sentimentos, mas, como afirma Rancière, "o conflito de vários regimes de sensorialidade" (RANCIĖRE, 2012, p. 59). O dissentimento visto como intrínseco ao processo é de fundamental importância para estabelecer a noção de conjunto e de pensamento compartilhado, resultando em uma cena polissêmica, carregada de significados, imprescindível para uma educação democrática. Os parâmetros para a 
evolução dos processos pedagógico e criativo são dados pela própria obra cênica em construção, como observa Viola Spolin:

são as exigências da própria forma de arte que devem nos apontar o caminho, moldando e regulando nosso trabalho, e remodelando a nós mesmos para enfrentar o impacto dessa grande força. Nossa preocupação é manter uma realidade viva e em transformação para nós mesmos, e não trabalhar compulsivamente por um resultado final [SPOLIN, 1979, p. 17].

A função de encenador-pedagogo não se restringe ao que se dará a ver, mas passa também pela organização do processo de pesquisa e experimentação, através da proposição de jogos, improvisações e estudos cênicos. Esta função que de certa maneira concentra os aspectos pedagógicos também é passível da "troca de papéis" no âmbito universitário, sendo compartilhada dentro do grupo, possibilita a todos o exercício de organização e composição das diversas vozes que compõem a encenação. Assim, a atuação do docente encenador pode ser modelar, traçando mapas de orientação, sem se caracterizar como totalizante:

Fazer o mapa, não o decalque. [...] Um mapa é aberto, é conectável em todas as suas dimensões, desmontável, reversível, suscetível de receber modificações constantemente. [...] Um mapa tem múltiplas entradas contrariamente ao decalque que volta sempre "ao mesmo". Um mapa é uma questão de performance, enquanto que o decalque remete sempre a uma presumida "competência" [DELEUZE e GUATTARI, 1995, p. 22].

A opção pela arte da encenação como operador na alfabetização teatral dos estudantes de licenciatura em teatro se dá, dessa maneira, por seu caráter polifônico, polissêmico e pedagógico, no qual as múltiplas traduções de materiais não-cênicos são parte de uma composição em dissenso. Ou, como afirma Denis Guénoun, "É necessário um ensino de direção (...), não para transmitir cânones acadêmicos - a objeção vem daqueles que só concebem pedagogia como sinônimo de conservatório - mas para entrelaçar invenção e transmissão" [GUÉNOUN, 2004, p. 162 , grifos do autor].

\subsubsection{A experiência alagoana}


Desde 2013, dentro do curso de Teatro Licenciatura da Universidade Federal de Alagoas (UFAL), estamos desenvolvendo um processo de formação do Professor de Teatro por meio da construção da cena. Didaticamente, o processo está inserido nos Planos de Curso da disciplina Projetos Integradores, oferecida em sete dos oito semestres de integralização desta graduação, procurando criar um diálogo crítico e criativo entre as disciplinas de um mesmo período letivo através da construção de exercícios cênicos a partir das práticas e teorias desenvolvidas nessas disciplinas. Dessa maneira, Projetos Integradores nos abriu a possibilidade de articular as teorias e práticas da linguagem teatral com as da pedagogia em sala de aula.

A articulação entre teoria e prática é das questões mais complexas enfrentadas nas graduações voltadas à formação de professores para a Educação Básica no Brasil. Colocar em prática as teorias pedagógicas estudadas nas licenciaturas enfrenta uma dificuldade de ordem estrutural: como reproduzir, no contexto universitário, as condições que o futuro professor enfrentará em sua atuação profissional?

No caso das licenciaturas nas linguagens artísticas, além dessa dificuldade apresenta-se uma característica singular em relação às demais que é a necessidade de articular não só as práticas e teorias pedagógicas, mas também articular o pensamento e a criação artísticos. A dificuldade em articular os saberes escolares, voltados à Educação Básica, a prática artística, voltada às questões técnicas e de artesania, e os conhecimentos provindos de uma visão poética e estética de mundo é característica da inserção do aprendizado artístico no ensino superior, o que se revela, muitas vezes, nos limites imprecisos entre bacharelado e licenciatura, dificultando ainda mais a formação dos professores de teatro. Nossa proposta para a disciplina Projetos Integradores foi a de realizar a integração de todas as disciplinas do período semestral por meio da construção de exercícios cênicos através de abordagens colaborativas na criação, apresentados publicamente na última semana de aulas com o objetivo de traduzir cenicamente os conteúdos teóricos e as práticas artísticas desenvolvidas.

Se inicialmente a proposta de criação de exercícios cênicos que articulassem os saberes teóricos e práticos de um semestre visava atender à ementa da disciplina Projetos Integradores, percebemos que através dela poderíamos realizar a 
alfabetização dos estudantes na linguagem teatral via encenação, aproximando-os de práticas educativas por meio da criação. A nova maneira de condução da disciplina provocou não só a mudança de percepção sobre a potencialidade dessa, mas também gerou transformações no próprio curso. A disciplina antes vista de forma desinteressada tanto por alunos como por professores passou a ser estruturante de cada um dos períodos e do próprio curso, como observa o aluno João Vitor Silva Leão, ingressante no curso em 2012, em protocolo produzido em aula:

As atividades e movimentações tomaram conta do nosso período de curso. Como já havia falado, não vejo mais aquele antiga dicotomia acadêmica, teoria e a prática. Absolutamente estamos construindo algo uníssono, integrado e compondo diversas ações, linguagens artísticas e as matérias que sustentam este semestre [INTEGRANDO, 2016, 16 jun 2013]. ${ }^{36}$

A criação de pequenas encenações age aglutinando a turma de alunos em torno de um projeto articulado a todas as disciplinas daquele período semestral. $O$ que se percebe é que os alunos, em geral, transformam a encenação no objeto de interesse comum, fazendo do aprendizado uma experiência coletiva. Essa compreensão muitas vezes acontece através da "troca de papéis", como observa Bruno Alves da Silva, ingressante no ano de 2010:

\begin{abstract}
A única coisa que ando lendo é "Orlando" da Vírginia Woolf e lembro de uma frase que me lembrou esse momento de construção que estamos vivendo, quando ela diz que "a roupa fala muito de nós. Somos o que vestimos". É que estamos em grupos divididos para a construção do espetáculo que comunique muito ou pouco de nós. Estamos vestindo, nos des-cobrindo e nos caracterizando de cenógrafos, iluminadores e tantas outras funções que fazem o teatro acontecer. Somos "Orlandos" também nesse processo de experimentação do ser homem, ser mulher, encontrando formas animadas de se comunicar e percebendo ao utilizar a máscara o quanto podemos provar até do estado neutro da vida [27 mar 2014].
\end{abstract}

Bruno refere-se ao processo desenvolvido pela turma do sétimo período do curso, no ano de 2014, em que a disciplina Laboratório de Práticas Teatrais foi direcionada por processos pedagógicos de atuação com máscaras, que seriam

${ }^{36}$ Um dos instrumentos pedagógicos utilizados por mim na disciplina Projetos Integradores é a produção rotineira de protocolos de aula. Parte desta produção dos alunos, aqui citada, está publicada na internet e pode ser acessada no blog Integrando: http://integradoresprojetos.blogspot.com.br/. 
utilizadas na encenação daquele período. O aluno percebe a troca das máscaras como metáfora da troca de funções que o processo colaborativo havia estabelecido, e como essas trocas de roupas, simbolizadas pelo Orlando, de Virgínia Woolf, são também uma troca de experiências, de formas de olhar e formas de dizer o que se viu e o que se entendeu: "O aluno deve ver tudo por ele mesmo, comparar incessantemente e sempre responder à tríplice questão: o que vês? o que pensas disso? o que fazes com isso? E, assim, até o infinito" [RANCIĖRE, 2010, p. 44].

O objeto de interesse em que se transforma a encenação para a turma de alunos, em geral, reflete-se nas demais disciplinas daquele período, pois o coletivo de alunos tende a ser mais atento, interessado, disponível e crítico em relação aos materiais que também comporão seu exercício espetacular. Frise-se que esse interesse do grupo é despertado pelo próprio processo colaborativo de criação e aprendizagem, como também foi destacado pelo aluno Bruno Alves da Silva:

Vale ressaltar a importância do Processo Colaborativo dentro do curso de Teatro Licenciatura, pois este faz com que todos os participantes possam pensar sobre o todo do processo, sabendo das escolhas e das decisões politicas e estéticas, não sendo mais aqueles que executam o que algum diretor ou encenador mandar, mas são aqueles que constroem juntos e assumem as responsabilidades na montagem cênica. São estes responsáveis pelos futuros alunos e alunas questionadores, construtores e colaboradores que não mais fazem a "pecinha de teatro" trazida pelo professor, mas em conjunto e orientação/provocação dele, constroem o que querem comunicar [22 jun 2014].

Bruno procura transpor o aprendizado coletivo da encenação no ensino superior para o ambiente escolar, para o qual está se formando como professor. Desta maneira, a construção de uma encenação não se limita aos aspectos de alfabetização na linguagem teatral dos futuros professores de teatro, mas transforma-se em um processo pedagógico que age na formação ética dos participantes, instaurando um processo de educação emancipatória.

\subsection{Olhar final}


Por fim, e porque é preciso concluir - já que as questões aqui problematizadas não se esgotam nas abordagens apresentadas -, pode-se dizer agora que o objeto inicial da pesquisa, a encenação como prática pedagógica na formação do Professor de Teatro, não mudou mas, surpreendentemente, foi ampliada. Nossa proposição de olhar a linguagem teatral no seu conjunto a partir do "texto" que se dá a ler ao espectador exprime uma perspectiva análoga à que defendemos na elaboração do Projeto Pedagógico do Curso de Teatro Licenciatura da UFAL e dos Referenciais Curriculares Alagoanos para a Educação Básica.

A alfabetização na linguagem teatral através de uma abordagem colaborativa na construção de uma encenação olha o conjunto de todas as linguagens artísticas que atravessam e compõem este "livro-encenação" e realiza o estudo desse material de maneira teórica e prática, isto é, distanciada como objeto de leitura e de cultura, e tácita como objeto de manipulação e criação. O objetivo final é a formação de "gente do teatro", ou seja, pessoas proficientes nesta linguagem através de suas habilidades artesanais, de sua perspectiva poética, de seu olhar estético e da compreensão da dimensão pedagógica dos processos de criação e aprendizagem.

A construção do PPC de Teatro Licenciatura procura olhar para o conjunto de estudos e atividades curriculares de ensino, extensão e pesquisa que atravessam e compõem a Pedagogia do Teatro dentro da universidade, tendo como referencial as formas teatrais e as modalidades pedagógicas - próximas e distanciadas -, oriundas tanto da tradição popular alagoana como de outras tradições teatrais. O objetivo é formar professores de teatro que saibam "abrir o mundo-teatro" para seus alunos, realizando a mediação entre sujeito e objeto, entre o popular e o erudito, entre a tradição e a contemporaneidade, a partir de uma perspectiva que elimina a distância entre as inteligências e assuma a responsabilidade ética em ser educador.

Os Referenciais Curriculares Alagoanos para Arte procuram olhar para o conjunto de materiais estéticos e poéticos que atravessam e compõem as linguagens artísticas a partir de uma abordagem pedagógica que contemple a apreciação, a produção e a reflexão. O objetivo é formar cidadãos que saibam ler o mundo e agir nele através de uma perspectiva artística que contemple o local e o universal, seu quintal e o mundo, a cultura como patrimônio, identidade e alteridade, 
e como material a ser recriado e transformado subjetiva e objetivamente, para que seja sempre viva e significante.

A formação do Professor de Teatro, para atuação na Educação Básica brasileira, precisa ser enfrentada em nossas pesquisas acadêmicas levando-se em consideração as especificidades do contexto da educação formal, caso contrário, nós, arte educadores, docentes artistas e artistas teatrais, perderemos a oportunidade de agir em um local no qual nossa arte pode ser estudada, praticada, apreciada e compreendida por ela e nela mesma. Através do ensino do Teatro na Educação Básica poderemos compartilhar e alargar nossa compreensão do fenômeno teatral sem nos colocarmos como "seres diferenciados", pois, parodiando Brecht, "erguendo uma tal divisória / Entre [nós] e o mundo, apenas [nos] lançam[os] / Fora do mundo" (BRECHT, 1986, p. 240).

Derrubar essas separações passa pela compreensão do sentido da escola em nossa sociedade, valorizando seu projeto radicalmente democrático. Assim, é necessário que a linguagem teatral se submeta às vontades da escola para que sua inteligência possa agir efetivamente na transformação da própria escola, abrindo a possibilidade para que as novas gerações construam um novo mundo em que o teatro, bem como todas as manifestações artísticas, seja visto por todos como forma de conhecimento do ser humano e do próprio mundo. É preciso compreender que o contexto escolar é diferente do contexto das ações socioculturais, bem como da formação no ofício, e que não basta aplicar métodos e "fórmulas de sucesso" de um contexto em outro. É preciso pensar a escola a partir da escola, e é nessa perspectiva que o ensino do teatro neste contexto deve ser colocado.

Nosso mundo está cada vez mais barulhento, pois todos querem exercer seus plenos direito políticos de se fazer ouvir e ver e talvez nos falte um tempo maior para escutar o que se diz e como se diz. Emancipar-se é não somente reconhecer-se capaz, mas também reconhecer no outro essa capacidade. É partir da igualdade como princípio, não como objetivo. Aí, talvez, esteja a chave para reconhecermo-nos como artistas, pedagogos e cidadãos. E capazes de amar. Amar o aluno e amar o mundo, amar ao próximo e amar o que nos faz ser o que somos. Na educação, amar é a conclusão a que chegaram Adorno, Arendt, Masschelein e Simons. Em Espinosa, "o amor não é senão a alegria acompanhada da ideia de uma causa 
exterior" (ESPINOSA, 1989, p. 120, grifos do autor) e a alegria é "a paixão pela qual a alma passa a uma perfeição maior" (p. 118, grifos do autor), e por isso, como já dizia Oswald de Andrade, em seu Manifesto Antropófago, "a alegria é a prova dos nove". 


\section{REFERÊNCIAS}

ABRACE - Associação Brasileira de Pesquisa e Pós-graduação em Artes Cênicas. Grupo de Trabalho: Pedagogia das Artes Cênicas. Disponível em: $<$ http://portalabrace.org/1/index.php/eixos-e-grupos-de-trabalho/grupos-de-trabalho/mais/gtpedagogia-do-teatro> Acesso em: 22 dez. 2015.

ABREU, Luís Alberto de. Raízes do processo colaborativo. In O Sarrafo, São Paulo, no 9, p. 14 , março de 2006.

Processo Colaborativo: relato e reflexões sobre uma experiência de criação. In Cadernos ELT, Santo André, vol. 1, no 0, pp. 33-41, março de 2003.

ADORNO, Theodor W. Educação e emancipação. Tradução de Wolfgang Leo Maar. São Paulo: Paz e Terra, 1995 (reimpressão 2012).

ADORNO, Theodor W. e HORKHEIMER, Max. Dialética do esclarecimento: fragmentos filosóficos. Tradução de Guido Antonio de Almeida. Rio de Janeiro: Zahar, 1985 (reimpressão 2006).

ALAGOAS. Referencial Curricular da Educação Básica da Rede Estadual de Ensino de Alagoas. Educação Básica. Referencial Curricular. Linguagens. Secretaria de Estado de Educação e do Esporte - SEE. Maceió, 2014. Disponível em: $<$ http://pt.slideshare.net/MariavieiraArauj/linguagens-cdigos-e-suas-tecnologias46741893?qid=19c073f4-da32-481a-87f0-636a7398e9a6\&v=qf1\&b=\&from search=65> Acesso em: 02 jul. 2015.

ALESSANDRA, Karla. Educação aprova Dança e Teatro como disciplinas obrigatórias do ensino básico, in Agência Câmara Notícias, 04/11/2013. Disponível em: $<$ http://www2.camara.leg.br/camaranoticias/noticias/EDUCACAO-E-CULTURA/456284EDUCACAO-APROVA-DANCA-E-TEATRO-COMO-DISCIPLINAS-OBRIGATORIAS-DOENSINO-BASICO.html> Acesso em: 11 abr. 2015.

ANDRADE, Mario. O baile das quatro artes. São Paulo: Martins Fontes, 1963. Disponível em: <http://docslide.com.br/documents/mario-de-andrade-o-artista-e-o-artesao.html> Acesso em: 27 fev. 2016.

ARENDT, Hannah. Entre o passado e o futuro. Tradução Mauro W. Barbosa. São Paulo: Perspectiva, 2011.

Reflexões sobre Little Rock. In Responsabilidade e julgamento. São Paulo: Cia. Das Letras, 2004, p. 160-281.

ARISTÓTELES. Poética. In Os Pensadores: Aristóteles - Volume II. Tradução de Eudoro de Souza. São Paulo: Nova Cultural, 1987.

ARTAUD, Antonin. O Teatro e seu duplo. Tradução de Teixeira Coelho. São Paulo: Max Limonad, 1984.

BALAGAN, Cia. Teatro. Formação do Olhar para o Teatro - $1^{\underline{a}}$ etapa, in Cadernos Pedagógicos: do inumano ao mais-humano (1 $1^{\text {a }}$ versão). Disponível em: <http://www.ciateatrobalagan.com.br/cadernos/cadernos-inumano/> 2012a.

BALAGAN, Cia. Teatro. Formação do Olhar para o Teatro - $2^{\mathrm{a}}$ etapa, in Cadernos Pedagógicos: do inumano ao mais-humano (1 $1^{\text {a }}$ versão). Disponível em: $<$ http://www.ciateatrobalagan.com.br/cadernos/cadernos-inumano/> 2012b. 
BARBOSA, Ana Mae. A bailarina e o poeta. In MARQUES, Isabel A. e BRAZIL, Fábio. Arte em questões. 2. ed. São Paulo: Cortez, 2014.

Arte Educação no Brasil: realidade hoje e expectativas futuras. In Revista Estudos Avançados, USP, vol. 3, no 7, 1989, p. 170-182. Tradução de Sofia Fan. Disponível em: <www.revistas.usp.br/eav/article/download/8536/10087> Acesso em: 24 mar. 2015.

Arte-educação no Brasil. 7. ed. São Paulo: Perspectiva, 2012.

BENJAMIN, Walter. O narrador. Considerações sobre a obra de Nikolai Leskov. In Obras escolhidas (volume 1). Magia e técnica, arte e política. Tradução de Sérgio Paulo Rouanet. São Paulo: Brasiliense, 1994.

BOAL, Augusto. Teatro do Oprimido e outras poéticas políticas. 11. ed. Rio de Janeiro: Civilização Brasileira, 2011.

BRASIL. Base Nacional Comum Curricular (versão inicial). Brasília: MEC/SEB, 2015.

Consulta quanto à obrigatoriedade da Educação Física como componente curricular da Educação Básica e sobre a grade curricular do curso de Educação Física da rede pública de ensino. Conselho Nacional de Educação. Parecer no 16/2001. Brasília: MEC/CNE, 2001. 1996.

Lei de Diretrizes e Bases da Educação Nacional. Lei no 9.394. 20 de dezembro de

Parâmetros curriculares nacionais: arte / Secretaria de Educação Fundamental (1 a a 4ª série, vol. 6 - Arte). Brasília: MEC/SEF, 1997a.

Parâmetros curriculares nacionais: arte / Secretaria de Educação Fundamental (5 a 8ª série). Brasília: MEC/SEF, 1998. MEC, 2000a.

Parâmetros Curriculares Nacionais (Ensino Médio). Parte I - Bases Legais. Brasília:

Parâmetros Curriculares Nacionais (Ensino Médio). Parte II - Linguagens, Códigos e suas Tecnologias. Brasília: MEC, 2000b.

. Plano Nacional de Educação - PNE. Lei no 13.005, de 25 de junho de 2014.

Parâmetros curriculares nacionais: introdução aos parâmetros curriculares nacionais / Secretaria de Educação Fundamental. Brasília: MEC/SEF, 1997b.

BRECHT, Bertolt. Estudos sobre o teatro. Tradução de Fiama Pais Brandão. Rio de Janeiro: Nova Fronteira, 1978.

1986.

Poemas 1913-1956. Tradução de Paulo Cesar Souza. São Paulo: Brasiliense,

CARVALHO, Jocianny Caetano Santos. Maresiando no colaborativo: o processo colaborativo como prática pedagógica. 2014. Monografia (Trabalho de Conclusão de Curso) - Instituto de Ciências Humanas, Comunicação e Artes, Universidade Federal de Alagoas, Maceió, 2014.

CHAUÍ, Marilena. Cultura do povo e autoritarismo das elites. In Cultura e Democracia: o discurso competente e outras falas. Cortez Editores, São Paulo, 2000.

. O que é ideologia (edição digitalizada por www.sabotagem.cjb.net, 2004). São Paulo: Brasiliense, 1980. 
COHEN, Renato. Work in Progress na cena contemporânea. São Paulo: Perspectiva, 1997.

COLI, Jorge. O que é arte? São Paulo: Brasiliense, 1995.

CONCILIO, Vicente. Professor de Teatro: existe? Pensando a profissionalização de quem ensina teatro. In Urdimento - Revista de Artes Cênicas / Universidade do Estado de Santa Catarina. Programa de Pós-Graduação em Teatro. Florianópolis: UDESC/CEART. Vol. 1, no 10, Dez 2008.

COURTNEY, Richard. Jogo, teatro e pensamento - as bases intelectuais do teatro na educação. Tradução de Karen Astrid Müller e Silvana Garcia. São Paulo: Perspectiva, 2003.

CUNHA, Manuela Carneiro da. "Cultura" e cultura: conhecimentos tradicionais e direitos intelectuais. In Cultura com aspas e outros ensaios. São Paulo: Cosac e Naify, 2009. Disponível em: <http://docslide.com.br/documents/cunha-manuela-carneira-da-cultura-ecultura-conhecimentos-tradicionais.html> Acesso em: 17 fev. 2016.

DELEUZE, Gilles, e GUATTARI, Félix. Mil Platôs - Vol. 1. Tradução: Aurélio Guerra Neto, Célia Pinto Costa. Editora 34, Rio de Janeiro, 1995.

O Que é a Filosofia? Tradução de Bento Prado Jr. e Alberto Alonso Muñoz. Editora 34, Rio de Janeiro, 1992.

DERISSO, José Luis. Construtivismo, Pós-modernidade e decadência ideológica. In MARTINS, Lígia M. e DUARTE, Newton (org.), Formação de professores: limites contemporâneos e alternativas necessárias. São Paulo: Cultura Acadêmica Editora, 2010.

DESGRANGES, Flavio. A inversão da olhadela: alterações no ato do espectador teatral. São Paulo: Hucitec, 2012.

A pedagogia do espectador. São Paulo: Hucitec, 2003.

Oficina de espectadores: a desmontagem como processo criativo. In Projeto Formação de Público 2001-2004, São Paulo, V. 1, p. 17-21, 2004.

2006.

Pedagogia do teatro: provocação e dialogismo. São Paulo: Hucitec/Mandacaru,

DIAS, Amanda Tavares. O ensino institucionalizado de Arte: para entender a diferença entre estar diante de alunos e ser professor. 2012. Monografia (Trabalho de Conclusão de Curso) - Escola de Comunicações e Artes, Universidade de São Paulo, São Paulo, 2012.

DUARTE, Newton. O debate contemporâneo das teorias pedagógicas. In MARTINS, Lígia M. e DUARTE, Newton (org.), Formação de professores: limites contemporâneos e alternativas necessárias. São Paulo: Cultura Acadêmica Editora, 2010.

- Vigotski e o "aprender a aprender", críticas às apropriações neoliberais e pósmodernas de teoria vigotskiana. 4. ed. Campinas, SP: Autores Associados, 2006.

e.MEC. Relatório de avaliação. Protocolo: 200815025. Código MEC: 786472. Código da Avaliação: 103695. Visita realizada entre 28 e 31 de maio de 2014, publicada em 16 de junho de 2014.

ESPINOSA, Baruch de. Ética. Tradução de Joaquim de Carvalho, Joaquim Ferreira Gomes e Antonio Simões. São Paulo: Nova Cultural, 1989. 
FERREIRA, Andrea Tereza Brito. Os saberes docentes e sua prática. In FERREIRA, Andréa Tereza Brito; ALBUQUERQUE, Eliana Borges Correia de; LEAL, Telma Ferraz (org.), Formação continuada de professores. Belo Horizonte: Autêntica, 2007.

FISCHER, Stela. Processo Colaborativo e experiências de companhias teatrais brasileiras. São Paulo: Hucitec, 2010.

FRANCIOLI, Fátima Aparecida de Souza. O trabalho do professor e a alfabetização: uma análise dos ideários educacionais. In MARTINS, Lígia M. e DUARTE, Newton (org.), Formação de professores: limites contemporâneos e alternativas necessárias. São Paulo: Cultura Acadêmica Editora, 2010.

FREIRE, Paulo. Pedagogia da autonomia. 33. ed. São Paulo: Paz e Terra, 2006.

FREITAS, Alexandre Simões. Os desafios da formação de professores no século XXI: competências e solidariedade. In FERREIRA, Andréa Tereza Brito; ALBUQUERQUE, Eliana Borges Correia de; LEAL, Telma Ferraz (org.), Formação continuada de professores. Belo Horizonte: Autêntica, 2007.

GALEANO, Eduardo. O livro dos abraços. Tradução de Eric Nepomuceno. 9. ed. Porto Alegre: L\&PM, 2002.

GALIZIA, Luiz Roberto. Os processos criativos de Robert Wilson. Ed. Perspectiva. São Paulo, 2005.

GAMA, Joaquim. Produto ou processo: em qual deles estará a primazia? In Sala Preta Revista de Artes Cênicas. Departamento de Artes Cênicas, Escola de Comunicações e Artes, Universidade de São Paulo, Número 2, 2002, p. 264-269.

GODARD, Jean-Luc. Je vous salue, Sarajevo (1993). Disponível em: <https://www.youtube.com/watch?v=LU7-o7OKuDg $>$ Acesso em 31 out. 2015.

GOMES, Ana Beatriz Pestana. Um Teatro Filosófico e uma Filosofia Teatral: Heiner Müller e Hannah Arendt. 2012. Dissertação (Mestrado em Filosofia). Universidade de Lisboa, Faculdade de Letras, Departamento de Filosofia, Lisboa, 2012.

GONÇALVES, Mateus. 1, 2, 3 e já! Brincando de ser professor de Teatro. In SILVEIRA, Fabiane T.; FERREIRA, Taís; LEITE, Vanessa Caldeira (org.), Conversações sobre Teatro e Educação. Porto Alegre: Observatório Gráfico, 2013.

GUALANDI, Alberto. Deleuze. Tradução Danielle O. Blanchard. São Paulo: Estação Liberdade, 2003.

GUÉNOUN, Denis. O Teatro é necessário? Tradução de Fátima Saadi. São Paulo: Perspectiva, 2004.

GUINSBURG, J. No rastro do Pós-modernismo. In GUINSBURG J. e BARBOSA, Ana M., O Pós-modernismo, p. 11-15. São Paulo: Perspectiva, 2005.

. O teatro no gesto. In Da cena em cena. São Paulo: Perspectiva, 2001.

HEGEL, G. W. F., Curso de Estética: o sistema das artes. Tradução de Álvaro Ribeiro. 2. ed. São Paulo: WMF Martins Fontes, 2010.

INTEGRANDO. Blog. Disponível em: <http://integradoresprojetos.blogspot.com.br/> Acesso em: 29 mar 2016. 
JAPIASSU, Ricardo Otoni Vaz. Metodologia do ensino de teatro. 9. ed. Campinas, SP: Papirus, 2010.

KONIGSON, Elie. Diviser pour jouer, in Les Cahiers de la Comêdie-Française, tradução para uso acadêmico de Célia Gouvêa, Paris, no 11, printemps, 1996, p. 42-49.

KOUDELA, Ingrid D. Brecht: um jogo de aprendizagem. 2. ed. São Paulo: Perspectiva, 2010.

Hífens e reticências.... In SANTANA, Arão Paranaguá de; SOUZA, Luiz Roberto de; RIBEIRO, Tânia Cristina Costa. Visões da ilha: apontamentos sobre teatro e educação. São Luís-MA: 2003.

. Jogos Teatrais. São Paulo: Perspectiva, 1984.

Texto e Jogo. Ed. Perspectiva. São Paulo, 1999.

KOUDELA, Ingrid D. e SANTANA, Arão Paranaguá. Abordagens metodológicas do Teatro na Educação. In CARREIRA, André et al. Metodologias de pesquisa em artes cênicas. Rio de Janeiro: Sete Letras, 2006.

LAFER, Celso. Da dignidade da política: sobre Hannah Arendt. In ARENDT, Hannah. Entre o passado e o futuro. Tradução Mauro W. Barbosa. São Paulo: Perspectiva, 2011.

LARROSA, Jorge. Tremores: escritos sobre experiência. Tradução Cristina Antunes e João Wanderley Geraldi. Belo Horizonte: Autêntica Editora, 2014.

LEMINSKI, Paulo. Toda poesia. São Paulo: Companhia das Letras, 2013.

LIBÂNEO, José Carlos. Adeus professor, adeus professora? - Novas exigências educacionais e profissão docente. São Paulo: Cortez Editora, 1998.

LIMA, Regileno Luiz de Souza. Arte-Educação em questão: a (in)visibilidade dos arteeducadores licenciados em teatro nas escolas do ensino fundamental de Maceió. 2012. Dissertação (Mestrado) - Instituto Universitário Centro Latino-americano de Economia Humana (CLAEH) / Centro de Educação Profissional e Superior Santa Maria Madalena CENFAP, Montevideo/Maceió, 2012

LYOTARD, Jean-François. A Condição Pós-Moderna. Tradução de Ricardo C. Barbosa. Rio de Janeiro, José Olympio, 2006.

MAAR, Wolfgang Leo. À guisa de introdução: Adorno e a experiência formativa. In ADORNO, Theodor W. Educação e emancipação. Tradução de Wolfgang Leo Maar. São Paulo: Paz e Terra, 1995 [reimpressão 2012].

MACHADO, Álvaro e THAÍS, Maria. O espectador-artífice o quarto criador. In THAÍS, Maria (org.), Balagan: Companhia de Teatro. São Paulo: Cia Teatro Balagan, 2014.

MARQUES, Isabel A. e BRAZIL, Fábio. Arte em questões. 2. ed. São Paulo: Cortez, 2014.

MARSIGLIA, Ana Carolina Galvão. Relações entre o desenvolvimento infantil e o planejamento de ensino. In MARTINS, Lígia M. e DUARTE, Newton (org.). Formação de professores: limites contemporâneos e alternativas necessárias. São Paulo: Cultura Acadêmica Editora, 2010.

MARTINS, Lígia Márcia. O legado do século XX para a formação de professores. In MARTINS, Lígia M. e DUARTE, Newton (org.). Formação de professores: limites contemporâneos e alternativas necessárias. São Paulo: Cultura Acadêmica Editora, 2010. 
MARTINS, Marcos Bulhões. Encenação em jogo: experimento de aprendizagem e criação do teatro. São Paulo: Hucitec, 2004.

O mestre-encenador e o ator como dramaturgo. In Sala Preta - Revista de Artes Cênicas. Departamento de Artes Cênicas, Escola de Comunicações e Artes, Universidade de São Paulo, Número 2, 2002, p. 240-246.

MASSCHELEIN, Jan e SIMONS, Maarten. Em defesa da escola: uma questão pública. Tradução Cristina Antunes. Belo Horizonte: Autêntica, 2013.

MATTOS, Aclyse de. A estética como poética não verbal: uma contemplação sinestésica de anúncio da linha Natura Tododia, trabalho apresentado no Congresso Internacional Comunicação e Consumo - COMUNICON2014. PPGCOM ESPM, São Paulo, 2014. Disponível em: <http://www.espm.br/download/Anais Comunicon 2014/gts/gt dez/GT10 MATTOS \%20Acl yse.pdf $>$ Acesso em: 19 set. 2015.

MEIERHOLD, V. O Teatro de Feira. Tradução Maria Thaís e Roberto Mallet. In Na Cena do Dr. Dapertutto: poética e pedagogia em V.E.Meierhold: 1911 a 1916. São Paulo: Perspectiva/Fapesp, 2009a.

Sobre a História e a Técnica do Teatro. Tradução Maria Thaís e Roberto Mallet. In Na Cena do Dr. Dapertutto: poética e pedagogia em V.E.Meierhold: 1911 a 1916. São Paulo: Perspectiva/Fapesp, 2009b.

Sobre o teatro. Tradução Maria Thaís e Roberto Mallet . In MARIA THAÍS, Na Cena do Dr. Dapertutto: poética e pedagogia em V.E.Meierhold: 1911 a 1916. São Paulo: Perspectiva/FAPESP, 2009c.

MERVANT-ROUX, Marie-Madeleine. O grande ressonador: o que a antropologia histórica e uma abordagem etnográfica a respeito do auditório podem nos dizer sobre as plateias. In About Performance, ํo 10, 2010, Audiencing: The Work of the Spectator in Live Performance, co-ed. Laura Ginters and Gay McAulay, University of Sidney, Department of Performnce Studies, tradução Camila Scudeler. Sidney, Austrália, 2010, p. 223-240.

Spectateur. In Michel CORVIN (dir.) Dictionnaire encyclopédique du théâtre, Bordas, réédition augmentée, 2008.

MESQUITA, Afonso Mancuso de. Os conceitos de atividade e necessidade para a Escola Nova e suas implicações para a formação de professores. In MARTINS, Lígia M. e DUARTE, Newton (org.). Formação de professores: limites contemporâneos e alternativas necessárias. São Paulo: Cultura Acadêmica Editora, 2010.

NAZARIO, Luiz. Quadro histórico do Pós-modernismo. In GUINSBURG J. e BARBOSA, Ana M., O Pós-modernismo, p. 23-70. São Paulo: Perspectiva, 2005.

NICOLETE, Adélia Maria. Da cena ao texto: dramaturgia em processo colaborativo. 2005. Dissertação (Mestrado em Artes). São Paulo: Departamento de Artes Cênicas, Escola de Comunicações e Artes, Universidade de São Paulo, 2005.

OLIVEIRA, Francine. A Narrativa e a experiência em Walter Benjamin. In $8^{\circ}$ Congresso da LUSOCOM. Anais. Lisboa, 2009.

OLIVEIRA, Manuella S. e PIZZI, Laura Cristina Vieira. Monitores e a precarização do trabalho docente em Alagoas. In VI Colóquio Internacional "Educação e Contemporaneidade". Anais. São Cristóvão-SE: 2012. Disponível em: <http://educonse.com.br/2012/eixo 04/PDF/66.pdf> Acesso em: 25 jun. 2015. 
OTRANTO, Célia Regina. A Nova LDB da Educação Nacional: seu trâmite no Congresso e as principais propostas de mudanças. In Revista Universidade Rural - Série Ciências Humanas - Vol. 18, no 1-2, Dezembro/1996. Disponível em: <http://www.celia.naweb.net/pasta1/trabalho3.htm > Acesso em: 08 abr. 2015.

PAVIS, Patrice. Dicionário de teatro. Tradução sob a direção de J. Guinsburg e Maria Lúcia Pereira. 2. ed. São Paulo: Perspectiva, 1999 (reimpressão 2003).

PESSOA, Fernando. Poesia / Alberto Caeiro. São Paulo: Companhia das Letras, 2001.

POLIDORO, Lurdes de Fátima, e STIGAR, Robson. A Transposição Didática: a passagem do saber científico para o saber escolar. In Ciberteologia - Revista de Teologia \& Cultura Ano VI, n. 27, 2010, p. 153-159.

PUPO, Maria Lúcia de Souza Barros. Além das dicotomias. In Anais do Seminário Nacional de Arte e Educação. Montenegro-RS: FUNDARTE, vol. 15, p. 31-34, 2001.

Dentro ou fora da escola? In Urdimento - Revista de Artes Cênicas / Universidade do Estado de Santa Catarina. Programa de Pós-Graduação em Teatro. Florianópolis: UDESC/CEART. Vol. 1, no 10, dez 2008.

. Entre o Mediterrâneo e o Atlântico, uma aventura teatral. São Paulo: Perspectiva/Capes/Fapesp, 2005a.

- Para desembaraçar os fios. In Revista Educação \& Realidade. Porto Alegre: Faculdade de Educação - UFRGS, vol. 30, nº 2, jul/dez 2005b.

Abraçar e ser abraçado. In DESGRANGES, Flavio. Pedagogia do teatro: provocação e dialogismo. São Paulo: Hucitec/Mandacaru, 2006.

Quando a cena se desdobra: as contrapartidas sociais. In DESGRANGES, Flavio; e LEPIQUE, Maysa (org.). Teatro e vida pública: o fomento e os coletivos teatrais de São Paulo. São Paulo: Hucitec / Cooperativa Paulista de Teatro, 2012.

RANCIÈRE, Jacques. A partilha do sensível: estética e política. Tradução de Mônica Costa Netto. 2. ed. São Paulo: Editora 34, 2009.

O espectador emancipado. Tradução de Ivone C. Benedetti. São Paulo: Editora WMF Martins Fontes, 2012.

O mestre ignorante: cinco lições sobre a emancipação intelectual. Tradução de Lílian do Valle. Belo Horizonte: Autêntica, 2010.

ROSA, Pedro Vals Feu. O Brasil precisa de mais leis? In Revista Congresso em foco, Brasília, 21/01/2014. Disponível em: <http://congressoemfoco.uol.com.br/legislacao/o-brasilprecisa-de-mais-leis/> Acesso em: 07 abr. 2015.

ROSENFELD, Anatol. Que é mise-em-scène? In Prismas do teatro. São Paulo: Perspectiva, 2000.

ROUBINE, Jean-Jacques. A linguagem da encenação teatral: 1880-1980. Tradução de Yan Michalski. 2. ed. Rio de Janeiro: Jorge Zahar Ed., 1998.

RUSS, Jacqueline. Dicionário de Filosofia. Tradução de Alberto Alonso Muñoz. São Paulo: Scipione, 1994. 
RYNGAERT, Jean-Pierre. Jogar, representar: práticas dramáticas e formação. Tradução de Cássia Raquel da Silveira. São Paulo: Cosac Naify, 2009.

. O jogo dramático no meio escolar. Tradução Christine Zurbach e Manuel Guerra. Coimbra (Portugal): Centelha, 1981.

SALA, Mauro. Alienação e emancipação na transmissão do conhecimento escolar: um esboço preliminar. In MARTINS, Lígia M. e DUARTE, Newton (org.). Formação de professores: limites contemporâneos e alternativas necessárias. São Paulo: Cultura Acadêmica Editora, 2010.

SALDANHA, Suzana. E o teatro na educação, como vai? In KÜHNER, Maria Helena, O Teatro dito infantil. Editora Cultura em Movimento - FCB, 2003.

SANTANA, Arão Paranaguá de. Teatro e formação de professores (edição on.line) São Luiz/MA: EDUFMA, 2009.

SANTOS, Vera Lúcia Bertoni dos. Shakespeare enfarinhado: estudos sobre teatro, jogo e aprendizagem. São Paulo: Hucitec, 2012.

SAYAD, Beatriz. Carnavalização e polifonia. In THAíS, Maria (org.), Balagan: Companhia de Teatro. São Paulo: Cia Teatro Balagan, 2014a.

SAYAD, Beatriz; SCHNEIDER, Maurício e THAíS, Maria. As evidências do processo. In THAÍS, Maria (org.), Balagan: Companhia de Teatro. São Paulo: Cia Teatro Balagan, 2014b.

SCHILLER, Friedrich. A educação estética do homem numa série de cartas. Tradução de Roberto Schwartz e Márcio Suzuki. São Paulo: lluminuras, 1995.

SCHMIEGUEL, Carlos. Conceito de lei em sentido jurídico. In Ágora - Revista de divulgação científica, Mafra, v.17, n. 1, 2010, pp. 128-134. Disponível em: $<$ http://www.periodicos.unc.br/index.php/agora/article/viewFile/55/162> Acesso em: 07 abr. 2015.

SENNETT, Richard. O Artífice. Tradução de Clóvis Marques. Rio de Janeiro: Record, 2009.

SILVA, Antonio Carlos de Araújo. A gênese da vertigem: o processo de criação de "O Paraíso Perdido". 2002. Dissertação (Mestrado em Artes) - Escola de Comunicações e Artes, Universidade de São Paulo, São Paulo, 2002.

A encenação no coletivo: desterritorialização da função do diretor no processo colaborativo. 2008. Tese (Doutorado em Teatro) - Escola de Comunicações e Artes, Universidade de São Paulo, São Paulo, 2008

SILVA, Edilene Barbosa da. Reflexões sobre o ensino do teatro. 2013. Monografia (Trabalho de Conclusão de Curso) - Instituto de Ciências Humanas, Comunicação e Artes da Universidade Federal de Alagoas, Maceió, 2013.

SILVA, Rosyer Souza. A importância do ensino de Artes nos colégios particulares. 2014. Monografia (Trabalho de Conclusão de Curso) - Instituto de Ciências Humanas, Comunicação e Artes da Universidade Federal de Alagoas, Maceió, 2014.

SLADE, Peter. O jogo dramático infantil. Tradução de Tatiana Belinky. São Paulo: Summus, 1978.

SPOLIN, Viola. Improvisação para o teatro. Tradução de Ingrid Koudela e Eduardo José de Almeida Amos. São Paulo: Perspectiva, 1979. 
SUZUKI, Márcio. O belo como imperativo. In SCHILLER, Friedrich. A educação estética do homem numa série de cartas. Tradução de Roberto Schwartz e Márcio Suzuki. São Paulo: lluminuras, 1995.

THAIS, Maria. Na Cena do Dr. Dapertutto: poética e pedagogia em V.E.Meierhold: 1911 a 1916. São Paulo: Perspectiva: Fapesp, 2009.

TIBURI, Márcia. Como conversar com um fascista. Disponível em: $<$ http://revistacult.uol.com.br/home/2015/05/como-conversar-com-um-fascista/> Acesso em: 28 out. 2015.

UFAL. Projeto Pedagógico do Curso de Teatro Licenciatura. Universidade Federal de Alagoas. Instituto de Ciências Humanas, Comunicação e Artes. Disponível em: <http://www.ufal.edu.br/estudante/graduacao/projetos-pedagogicos $>$ Acesso em: 13 abr. 2015.

USP. Organização das linhas de pesquisa do Programa em Pós-graduação em Artes Cênicas. Universidade de São Paulo. Escola de Comunicações e Artes. Secretaria de Pósgraduação. Disponível em: <http://www3.eca.usp.br/pos/ppgac/apresentacao/organizacaodas-linhas-de-pesquisa> Acesso em: 22 dez. 2015.

VALCÁRCEL, Amelia. Ética contra estética. Tradução de Newton Cunha. São Paulo: Perspectiva/SESC, 2005. 


\section{ANEXOS}

\section{ANEXO A}

\section{CARTA ABERTA AOS GOVERNOS E GESTORES EDUCACIONAIS DOS DOCENTES DAS LICENCIATURAS EM DANÇA E EM TEATRO DO BRASIL}

Nós, professores e professoras dos cursos de Artes Cênicas, Licenciaturas em Teatro e Licenciaturas em Dança, abaixo-assinados, solicitamos medidas concretas que garantam o cumprimento da Lei de Diretrizes e Bases da Educação de 1996, que estabelece que o ensino da Arte constitui "componente curricular obrigatório, nos diversos níveis da educação básica" (BRASIL, 1996, Art. 26, § $2^{\circ}$ ). $\mathrm{Da}$ mesma forma, manifestamos nossa indignação com 0 fato de ainda se realizarem concursos públicos e seleções docentes ignorando o que garante a referida LDB.

Há um número grande de licenciados egressos das diversas áreas da Arte que enfrentam dificuldade para assumirem seu lugar de direito nessa disciplina nas escolas de educação básica das redes públicas municipais, estaduais e federal em decorrência de editais mal elaborados, que não contemplam as licenciaturas em teatro e dança ou que simplesmente ignoram que teatro e dança são formações docentes legítimas. O mesmo acontece nas redes privadas de ensino, que muitas vezes desconsideram a existência destes profissionais em suas seleções e currículos. Em decorrência disso, o que se verifica é uma grande carência de professores com essas formações específicas, na maior parte das escolas, sejam elas públicas ou privadas, não possibilitando, consequentemente, aos alunos o desenvolvimento necessário nesses campos de saber.

Ao atuarmos como professores das Licenciaturas em Teatro e Dança, temos acompanhado esse tipo de equívoco acontecendo de norte a sul do país, sendo exemplos recentes o impedimento da participação em concursos públicos para professores da educação básica de egressos dos cursos de licenciatura em Teatro nas cidades de São Luís (MA) e Santa Maria (RS), somente para citar a "amplitude geocultural" alcançada pelo problema, que urge ser sanado em nossas estruturas educacionais.

Os profissionais formados nestas licenciaturas não têm ocupado os espaços legítimos que o ensino de Teatro e Dança teria garantido por lei nas escolas, sendo necessário, muitas vezes, a abertura de processos para que suas admissões sejam garantidas em cumprimento de decisão judicial.

$\mathrm{Na}$ trajetória histórica do ensino de Artes no Brasil, uma quantidade significativa de leis, decretos e resoluções têm sido emitidos, enfatizando a sua importância como disciplina que deve integrar o currículo de todas as séries da Educação Básica. Após a LDB de 1996, a Lei oㅡ 2.287, de 13 de julho de 2010, passa a garantir ainda: "§ $20 \mathrm{O}$ ensino da arte, especialmente em suas expressões regionais, constituirá componente curricular obrigatório nos diversos níveis da educação básica, de forma a promover o desenvolvimento cultural dos alunos".

Visto que a mesma lei aponta que um dos deveres do Estado é "elaborar e executar políticas e planos educacionais, em consonância com as diretrizes e planos nacionais de educação, integrando e coordenando as suas ações e as dos seus Municípios", observamos que é responsabilidade do Estado pôr em prática diretrizes das políticas educacionais que atendam de forma eficaz às necessidades da 
educação, garantindo a abertura de vagas e admissão através de concursos públicos para professores habilitados nos cursos de Licenciatura em Teatro, Licenciatura em Dança e Licenciatura em Artes Cênicas, assim como em Música e Artes Visuais.

Temos constatado, estarrecidos, que ainda em 2015 alguns gestores e autoridades das Secretarias de Educação Municipais e Estaduais e inclusive gestores de Institutos Federais (que possuem ensino médio) de nosso país desconhecem as referidas leis, pois seguem realizando concursos de caráter genérico na área de Artes e/ou desconsiderando as formações específicas. Verificamos da mesma forma a falta de clareza por parte de muitos professores, diretores e gestores sobre como se planeja e operacionaliza o currículo nessas distintas linguagens artísticas, conforme previsto nos Parâmetros Curriculares Nacionais para a área de Arte, tanto nos anos iniciais como finais do Ensino Fundamental, bem como no Ensino Médio, acrescidos dos Referenciais Curriculares para a Educação Infantil, que também contemplam as já referidas quatro linguagens artísticas.

Estamos certos de que só há um caminho para os egressos desses cursos superarem as dificuldades enfrentadas: a realização de concursos públicos que contemplem as diversas formações em Arte e a transparência na divulgação de informações relativas a esses. Além disso, o diálogo com gestores educacionais das redes públicas e privadas de ensino e o esclarecimento da necessidade de professores de Teatro e Dança em seus quadros é urgente.

Colocamo-nos aqui à disposição, como professores formadores de licenciados em Teatro e Dança, dos governos e gestores escolares para possíveis esclarecimentos que se fizerem necessários na elaboração de editais, abertura de vagas e construções curriculares na área.

Com essa declaração, nós apelamos que se façam cumprir as leis referidas nesta missiva e que possamos, efetivamente, ter nossos egressos ocupando o lugar que lhes é de direito e para o qual foi voltada, fundamentalmente, sua formação universitária: a docência em teatro e dança na educação básica.

Agradecemos a atenção, subscrevendo-nos, certos da compreensão dos leitores da relevância desta questão no campo educacional brasileiro.

Cordialmente, 


\section{ANEXO B}

\section{PARECER CNE/CEB 16/2001 - HOMOLOGADO}

Despacho do Ministro em 21/11/2001, publicado no Diário Oficial da União de 3/12/2001, Seção 1, p. 9.

INTERESSADO: Ministério do Esporte e Turismo/Secretaria Nacional de Esporte e Ministério Público da União/Promotoria de Justiça de Defesa da Educação. UF: DF

ASSUNTO: Consulta quanto à obrigatoriedade da Educação Física como componente curricular da Educação Básica e sobre a grade curricular do curso de Educação Física da rede pública de ensino

RELATOR: Nelio Marco Vincenzo Bizzo

PROCESSO N.: :23001.00015120001-42 e 2001.0008020001-88

PARECER N...: 16/2001. COLEGIADO: CEB. APROVADO EM: 03/07/2001

\section{I-RELATÓRIO}

\section{Histórico:}

Em 9 de Março do presente a Secretaria Nacional do Esporte do Ministério do Esporte e Turismo encaminhou consulta sobre a obrigatoriedade da educação física como componente curricular da educação básica. A matéria foi apensada à outra de teor semelhante, de iniciativa do Ministério Público da União, da Promotoria de Justiça de Defesa da Educação do Distrito Federal, em missiva apresentada ao protocolo do MEC em 25 de Maio pp. Nesta última indagava-se especificamente sobre a exigibilidade de formação específica em Educação Física para os quatro primeiros anos do ensino fundamental. Além disso, perguntava-se sobre a pertinência de oferecimento de educação física em turno diverso do horário normal das atividades escolares.

\section{Mérito:}

Deve-se diferenciar a Educação Física, entendida como conjunto de atividades relativas às dimensões ética, estética e lúdica, à mobilidade do corpo, à manutenção do tônus muscular, da coordenação motora, da higidez, etc, que constituem um conjunto de saberes e habilidades que configuram um componente curricular da escola básica, de outros tipos de atividades físicas, como as práticas desportivas. Embora não sejam mutuamente excludentes, deve-se lembrar que constituem conjunto distinto de atividades as práticas esportivas de tipo recreativo ou voltadas ao desempenho olímpico, de competição, do esporte amador ou profissional. O primeiro conjunto deve ser objeto de trabalho cotidiano nas escolas; 0 segundo, sem dúvida, exige condições especiais e profissionais especializados.

Tendo em foco a Educação Física como parte do trabalho cotidiano nas escolas, investigaremos, primeiramente, a Educação Física nos quatro primeiros anos do ensino fundamental e a pertinência legal de exigir-se profissional especialmente qualificado para tal fim. 
Nos quatro primeiros anos do ensino fundamental, a prática multidisciplinar é amplamente disseminada entre nós. A Matemática não é ensinada por matemático, a Língua Portuguesa não é ensinada por diplomado em Letras, e assim o é com tantos quantos forem os conteúdos curriculares. A generalidade da formação do professor que milita nos anos iniciais do ensino fundamental tem fundamento na legislação em vigor, fazendo parte de longa tradição que se acumula por várias gerações. Certamente cada um de nós teve uma professora generalista nas primeiras letras e números e assim o foi com nossos pais, avós e bisavós. Esta tradição tem sua raiz legal em ato do Imperador D. Pedro I que promulgou, em 15 de Outubro de 1827, o primeiro estatuto do magistério, data que constitui efeméride emblemática em nossos dias. Lá se estipulava a atuação multidisciplinar dos professores das primeiras letras, em especial em seu artigo 6o, que afirmava:

"Art. 6o. Os professores ensinarão a ler, escrever, as quatro operações de arithmetica, pratica de quebrados, decimaes e proporções, as noções mais geraes de geometria pratica, a grammatica da lingua nacional, e os princípios de moral christã e da doutrina da religião católica e apostólica romana, proporcionados á compreensão dos meninos; preferindo para as leituras a Constituição do Império e a Historia do Brazil."

Não é apenas a referência legal mais antiga que aponta para a atuação multidisciplinar do professor dos primeiros anos, mas também a referência legal mais recente. De fato, a Lei 10.172, de 9 de Janeiro de 2001, que institui o Plano Decenal de Educação também o faz. Nele, são abordadas as classes e escolas unidocentes (2.3), a formação inicial e continuada para atuação multidisciplinar (10.2), colocando como meta para os próximos cinco anos (10.3, \#17) a garantida de formação em nível médio, na modalidade normal, de $100 \%$ dos professores da educação infantil e das quatro primeiras séries do ensino fundamental. Reafirma-se ainda que a educação escolar não se reduz à sala de aula e se viabiliza pela ação articulada entre todos os agentes educativos.

A modalidade normal do ensino médio habilita os profissionais a ministrarem aulas de todos os conteúdos curriculares, sem exceção, o que se confirma na longa tradição educacional brasileira, desde o emblemático dia 15 de Outubro de 1827.

Espera-se que os cursos de formação inicial e continuada de professores incluam, dentre seus temas de estudo e de prática de ensino, os diversos componentes curriculares, inclusive Educação Física. A clara dicção do texto constitucional, ao afirmar que a educação obrigatória deve ser de qualidade, implica em garantir que os alunos tenham aulas de todos os componentes curriculares, mormente nos quatro primeiros anos do ensino fundamental. Proibir ou cercear a atividade docente multidisciplinar em um componente curricular específico implicaria em afrontar os termos da Carta Magna e contrariar uma longa tradição educacional.

Não existe dúvida a respeito da pertinência de se franquear a atuação de profissionais especializados nos quatro primeiros anos do ensino fundamental, em qualquer de suas séries, semestres, ciclos etc. A orientação de higiene bucal, por exemplo, deveria ser feita preferivelmente por odontologista habilitado e especializado, as noções de puericultura deveriam ser feitas por enfermeira ou pediatra credenciado e especializado, bem como a Educação Física deveria contar com a assistência de profissional especializado. No entanto, disso não decorre que 
os professores de atuação multidisciplinar estejam impedidos de realizar essas atividades e em especial as preconizadas na Proposta Pedagógica da Escola, dado que se encontram em sua esfera de obrigações.

Assim, conclusivamente, não assiste razão a quem evoca a lei para restringir o direito ao exercício profissional do professor de atuação multidisciplinar em qualquer um dos conteúdos curriculares dos anos iniciais do ensino fundamental ou da educação infantil. Mesmo se o componente curricular configurar disciplina específica, inclusive Educação Física, ela poderá ser ministrada por profissional legalmente licenciado para o exercício docente nos quatro primeiros anos do ensino fundamental. Associações profissionais de classe, de pais e professores, os órgãos do poder executivo em todos os níveis etc. deveriam envidar esforços para que os professores tivessem condições objetivas de aprimorar seu desempenho profissional em todos os componentes curriculares. Cursos de formação continuada, inclusive para a prática de educação física pelas crianças da educação infantil e dos primeiros anos do ensino fundamental, são formas eficazes de caminhar em direção a práticas satisfatórias de educação física nas escolas.

Examinemos a atuação docente nos quatro últimos anos do ensino fundamental e no Ensino Médio, em relação a duas questões básicas. A primeira delas se refere à obrigatoriedade do oferecimento de disciplina específica (Educação Física) em todos os anos como decorrência de sua condição de componente curricular. A segunda questão se refere a obrigatoriedade de profissional específico para ministra-la.

O artigo 26 da LDB cita como componentes curriculares o estudo da língua portuguesa e da matemática, o conhecimento do mundo físico e natural e da realidade social e política, especialmente do Brasil. Além deles, são citados o ensino da arte, o ensino da História do Brasil o ensino de uma língua estrangeira moderna, ao lado de educação física. Neste último caso a lei diz que ela deverá estar integrada à Proposta Pedagógica da Escola.

Alguns componentes curriculares especificados correspondem literalmente a nomes consagrados de disciplinas do ensino fundamental, como é o caso de Língua Portuguesa e Matemática. Mas certamente esse não é o caso de conhecimento do mundo físico e natural, realidade social e política e mesmo de História do Brasil. Esses componentes curriculares deverão ser contemplados quando da elaboração da Proposta Pedagógica da Escola, integrados às áreas de conhecimento mencionadas nas Diretrizes Curriculares Nacionais, como se verá adiante.

O Parecer CNE/CEB 05/97 tratou de dirimir dúvidas quanto a diversos aspectos da LDB em relação à concretização curricular nas escolas

"Além desse complemento curricular (parte diversificada), o legislador impôs (art. 27), tanto nas finalidades como sob a forma de diretrizes, objetivos que não se enquadram como componentes curriculares propriamente ditos, visto que abrangem a base comum nacional e a diversificação, ou seja, não de natureza ético/social. Dizem respeito a valores fundamentais ao interesse social, direitos e deveres dos cidadãos, envolvendo respeito ao bem comum e à ordem democrática, como fundamentos da sociedade. Abrangem formação de atitudes, preparação para 0 trabalho, para a cidadania e para a ética nas relações humanas." 
(...)

"A tais componentes curriculares, somam-se a 'educação física, ajustando-se às faixas etárias e às condições da população escolar, sendo facultativa nos cursos noturnos' e o ensino de pelo menos uma língua estrangeira moderna, cuja escolha ficará a cargo da comunidade escolar, dentro das possibilidades da instituição. Existe indagação referente ao dispositivo que torna facultativa a educação física nos cursos noturnos. Pergunta-se se a faculdade assegurada na lei é para o aluno ou para a escola. Certamente, à escola caberá decidir se deseja oferecer educação física em cursos que funcionem no horário noturno (artigo $26 \S 3^{\circ}$ ). E, ainda que o faça, ao aluno será facultado optar por não freqüentar tais atividades, se esta for a sua vontade. Nunca será demais enfatizar que somente serão computados nas oitocentas horas de que fala a lei, os componentes a que o aluno esteja obrigado, nelas não se incluindo, por exemplo, a educação física nos cursos noturnos e o ensino religioso."

Este parecer deixa clara a existência de modalidades de componentes curriculares, ao discorrer sobre componentes curriculares propriamente ditos. Não seria difícil depreender-se a existência de um tipo de componente curricular que corresponde a disciplinas escolares e outro, ou outros, que não são componentes curriculares propriamente ditos, mas que devem fazer parte do currículo, mesmo não constituindo disciplina escolar específica. Esse é o caso citado de atitudes e valores mais gerais da sociedade bem como o é, como veremos adiante, a educação ambiental, os temas transversais etc. Além disso, o parecer esclarece que a Educação Física em cursos noturnos não teria oferta obrigatória e, quando fosse oferecida nesses cursos, ela não poderia ser contabilizada para cumprir a carga horária anual estipulada pela LDB.

Portanto, o exame da LDB e do Parecer CNE/CEB 05/97 que a esclarece, não permite concluir que os componentes curriculares devam configurar disciplinas homônimas. Antes disso, deverão fazer parte da Proposta Pedagógica da Escola, que detalhará a modalidade na qual serão abordados ao longo do trabalho pedagógico.

Para investigar mais profundamente a vinculação obrigatória ou não entre um componente curricular obrigatório e uma disciplina escolar específica, caberia uma analogia entre a Educação Física e a Educação Ambiental. A Lei 9.795/1999 estabelece a Educação Ambiental como componente essencial e permanente da educação nacional, devendo estar presente, de forma articulada, em todos os níveis e modalidades do processo educativo. Não resta dúvida que se trate de componente curricular obrigatório na escola básica inclusive. No entanto, em seu artigo 10, afirma:

"Art 10. A educação ambiental será desenvolvida como uma prática educativa integrada, contínua e permanente em todos os níveis e modalidades do ensino formal.

§ 10. A educação ambiental não deve ser implantada como disciplina específica no currículo de ensino."

Note-se, pois, que a mesma lei que determina a inclusão de um componente curricular recomenda que ele não constitua disciplina específica. A legislação em 
vigor tem outras evidências da desvinculação direta e automática entre componentes curriculares e disciplinas específicas.

As Diretrizes Curriculares Nacionais Para o Ensino Fundamental (Res. CNE/CEB 02/98), estabelecem que o paradigma curricular do ensino fundamental deverá estar articulado com a vida cidadã e com áreas de conhecimento:

“IV - Em todas as escolas deverá ser garantida a igualdade de acesso para alunos a uma base nacional comum, de maneira a legitimar a unidade e a qualidade da ação pedagógica na diversidade nacional. A base comum nacional e sua parte diversificada deverão integrar-se em torno do paradigma curricular, que vise a estabelecer a relação entre a educação fundamental e:

a) a vida cidadã através da articulação entre vários dos seus aspectos como:

1. a saúde

2. a sexualidade

3. a vida familiar e social

4. o meio ambiente

5. o trabalho

6. a ciência e a tecnologia

7. a cultura

8. as linguagens.

b) as áreas de conhecimento:

1. Língua Portuguesa

2. Língua Materna, para populações indígenas e migrantes

3. Matemática

4. Ciências

5. Geografia

6. História

7. Língua Estrangeira

8. Educação Artística

9. Educação Física

10. Educação Religiosa, na forma do art. 33 da Lei 9.394, de 20 de dezembro de 1996."

Deve-se ressaltar o emprego do termo "áreas de conhecimento" e não "disciplinas". Isso não deve ser visto como acidental, de vez que o espírito da própria LDB é o de conferir autonomia pedagógica às escolas, de maneira a induzi-las a elaborar projetos pedagógicos que estejam adequados à sua própria realidade. Tomemos uma escola rural isolada e uma escola dotada de equipamentos como piscina, por exemplo. Seria impossível pretender que tivessem, ambas, as mesmas atividades e disciplinas referentes à prática de Educação Física. Ambas estão obrigadas a oferecer Educação Física a seus alunos do curso diurno, na maneira como sua Proposta Pedagógica o especificar. É evidente que uma escola dotada de equipamentos especiais pode desenvolver uma proposta pedagógica mais sofisticada em relação à Educação Física, tanto na forma de disciplina específica como no oferecimento complementar de práticas desportivas, o que possivelmente não será o caso de escolas de instalações mais modestas, que seguramente constituem a regra em nossa realidade. 
A recente Portaria Interministerial 73, de 23 de Junho de 2001, instituiu a Educação Física como componente curricular obrigatório, o que vem a reforçar os termos deste parecer, no sentido da incorporação obrigatória da Educação Física à proposta pedagógica da escola.

Conclui-se, portanto, que não existe vinculação direta entre componente curricular, mesmo obrigatório, e disciplina específica no currículo de ensino. Nos quatro últimos anos do ensino fundamental, no período diurno, a Educação Física deve figurar obrigatoriamente na Proposta Pedagógica da Escola, mesmo que não constitua disciplina escolar específica. Os Parâmetros Curriculares Nacionais contemplam a prática da Educação Física e oferecem importantes subsídios para sua incorporação aos projetos pedagógicos, de maneira a potencializar as indiscutíveis vantagens de sua prática rotineira.

O Poder Público, mormente o Ministério do Esporte e Turismo e sua Secretaria Nacional de Esporte em articulação com a Secretaria de Educação Fundamental do Ministério da Educação, poderia desenvolver programas com vistas ao incremento da Educação Física em suas diversas modalidades nas escolas do Ensino Fundamental. O Plano Nacional de Educação cita aspectos de instalações físicas que as construções escolares deveriam ter, elegendo como objetivos e metas elaborar, no espaço de um ano, padrões mínimos nacionais de espaços para esporte e recreação entre outros (2.3.4 \#c). No segundo ano de vigência do Plano Nacional de Educação a autorização de construção de unidades escolares deveria obrigatoriamente seguir o padrão estipulado (2.3.5), o que seria exigido de todas as unidades escolares no espaço de cinco anos(2.3.6).

Examinemos a situação do ensino médio. As Diretrizes Curriculares Para o Ensino Médio (Res. CNE/CEB 03/98) dispõem da mesma forma em relação à constituição de Proposta Pedagógica da Escola contemplando três áreas de conhecimento, que não correspondem biunivocamente a disciplinas:

"Art. 10 A base nacional comum dos currículos do ensino médio será organizada em áreas de conhecimento, a saber:

I - Linguagens, Códigos e suas Tecnologias, (...)

II - Ciências da Natureza, Matemática e suas Tecnologias, (...)

III - Ciências Humanas e suas Tecnologias, (...)

$\S 1^{\circ}$ A base nacional comum dos currículos do ensino médio deverá contemplar as três áreas do conhecimento, com tratamento metodológico que evidencie a interdisciplinaridade e a contextualização.

$\S 2^{\circ}$ As propostas pedagógicas das escolas deverão assegurar tratamento interdisciplinar e contextualizado para:

a) Educação Física e Arte, como componentes curriculares obrigatórios;

b) Conhecimentos de filosofia e sociologia necessários ao exercício da cidadania."

Deve-se notar, novamente, que nenhuma das áreas de conhecimento configura disciplina escolar tradicional. A Educação Física é mencionada como componente curricular obrigatório que deve fazer parte da proposta pedagógica da escola. 
Portanto, no Ensino Médio repete-se a situação presente no Ensino Fundamental, qual seja, a obrigatoriedade de inclusão da Educação Física nos cursos diurnos como componente curricular, mas não necessariamente na forma de disciplina específica. Por decorrência, não se pode pretender implantar algo como docência de áreas de conhecimento ou de componentes curriculares, tal qual a Educação Ambiental, restrita a profissionais especializados, ou seja, com credencial profissional específica.

Da mesma forma como foi dito para o Ensino Fundamental, caberia lembrar que o Plano Nacional de Educação dispõe sobre padrões mínimos nacionais de infraestrutura para o ensino médio, inclusive espaço para esporte e recreação, e que a colaboração entre a Secretaria Nacional de Esporte, do Ministério do Esporte e Turismo, e a Secretaria de Ensino Médio e Tecnológico do Ministério da Educação poderia trazer significativo avanço para a disseminação e aprimoramento da Educação Física em nossas escolas.

Mesmo extrapolando o escopo deste Parecer, caberia ainda mencionar que o Parecer CNE/CES 1137/99 reafirmou o caráter facultativo da Educação Física como componente curricular na Educação Superior.

Conclusivamente, pode-se afirmar que a Educação Física deve estar inserida na proposta pedagógica das escolas no ensino fundamental e médio, nos cursos oferecidos no período diurno. Caso esteja prevista a inclusão de uma disciplina específica denominada Educação Física, não resta dúvida sobre o cumprimento dos requisitos legais vigentes. No entanto, o projeto pedagógico poderá dispor esse componente curricular de forma diversa, desde que de acordo com a lei. Por último, deve-se ressaltar que não cabe evocar o artigo 81 da lei 9394/95, que permite a organização de cursos ou instituições de ensino experimentais, dado que o mesmo artigo estabelece que devem ser obedecidas as disposições desta Lei, a qual, no art. 26, dispõe inequivocamente quanto à inclusão de componentes curriculares.

Uma vez definida a relação entre componentes curriculares, proposta pedagógica e disciplina escolar específica, resta investigar a pertinência de se restringir a docência de Educação Física nas escolas a profissionais especializados.

De início, cabe ressaltar que a LDB dispõe sobre a constituição de Sistemas de Ensino pela União, Estados, Distrito Federal e Municípios, que deverão atuar em regime de colaboração, baixando normas e conferindo-lhes liberdade de atuação, nos termos da legislação. Existe, assim, ampla gama de possibilidades de articulação da Educação Física com o currículo da escola e os Sistemas de Ensino podem dispor a esse respeito, de acordo com os artigos 10 e 11 da LDB. Em todos os casos, o diploma que confere a graduação habilitadora aos profissionais da Educação em todo o território nacional é o de Licenciatura Plena, conforme os Art. 62, Art. 67 e Art. 87 da Lei 9394/96.

No caso de o componente curricular Educação Física ser oferecido na forma de disciplina específica nos quatro últimos anos do ensino fundamental e no ensino médio, no período diurno ou noturno, ele deverá ser ministrado por profissional legalmente licenciado. No turno diurno, a carga horária da disciplina fará parte das 800 horas anuais obrigatórias; no turno noturno, sua carga horária não poderá ser contabilizada para efeito do mínimo legal. Caso o componente curricular Educação 
Física não constitua disciplina, na forma especificada no projeto pedagógico da escola e de acordo com as disposições vigentes no respectivo sistema, ela deverá ser ministrada igualmente por profissional legalmente licenciado. A mesma exigência não se aplica a práticas desportivas de modo geral, que devem ser acompanhadas por profissional especializado e contar com infraestrutura e condições adequadas.

Em todos os casos, a proposta pedagógica da escola deverá contemplar o componente Educação Física, no ensino fundamental e no ensino médio. Não se deve confundir o estímulo a práticas desportivas, no recinto escolar ou alhures, com o componente curricular Educação Física de que trata o art. 26 de lei 9394/96. É necessário que as propostas pedagógicas das escolas contemplem as demandas locais e de suas clientelas, ao mesmo tempo em que se incorporam os conhecimentos científicos que apontam para a necessidade de regularidade no exercício físico ao longo de toda a trajetória escolar.

\section{II- VOTO DO RELATOR}

Voto nos termos deste parecer, sendo notificada a Secretaria Nacional de Esporte, a Promotoria de Justiça e Defesa da Educação do Distrito Federal, as Secretarias de Ensino Fundamental e de Ensino Médio e Tecnológico do Ministério da Educação, os Conselhos Estaduais de Educação por meio do Fórum Nacional de Conselhos Estaduais de Educação, as Secretarias Estaduais de Educação por meio do Conselho Nacional de Secretários de Educação (CONSED) e o Conselho Federal de Educação Física.

Brasília (DF), 03 de julho de 2001.

Conselheiro Nelio Marco Vincenzo Bizzo- Relator

\section{III - DECISÃO DA CÂMARA}

A Câmara de Educação Básica aprova por unanimidade o voto do Relator.

Sala das Sessões, em 03 de julho de 2001

Conselheiro Francisco Aparecido Cordão - Presidente

Conselheiro Carlos Roberto Jamil Cury 
ANEXO C

\section{REFERENCIAL CURRICULAR DA EDUCAÇÃO BÁSICA DA REDE DE ENSINO ESTADUAL DE ALAGOAS}

ALAGOAS. Secretaria de Estado de Educação e do Esporte - SEE. Referencial Curricular da Educação Básica da Rede Estadual de Ensino de Alagoas. Educação Básica. Referencial Curricular. Linguagens. 1를 edição, Maceió-AL, 2014 (224p.). http://pt.slideshare.net/MariavieiraArauj/linguagens-cdigos-esuas-tecnologias-46741893?qid=19c073f4-da32-481a-87f0-

636a7398e9a6\&v=qf1\&b=\&from search=65. (acesso em 02/07/2015)

Volume LINGUAGENS

Páginas 112-123.

[p.112]

4.6.3 Arte

Sistematização do Referencial Curricular para o Ensino da Arte.

O ensino da Arte como Componente Curricular é ministrado na educação escolar básica de acordo com a Lei de Diretrizes e Bases da Educação Nacional brasileira (9.394/96), que disciplina a educação escolar, e com as Diretrizes e os Parâmetros Curriculares Nacional de Arte (PCN-Arte). A obrigatoriedade de ensino deste componente curricular é recente, bem como sob esta denominação de Arte. Tal fato se deve a dificuldades de compreensão, ao longo da história, da necessidade e da importância das artes na formação do sujeito. Dificuldades que podem ser explicitadas através das modificações que 0 ensino das linguagens artísticas foi sofrendo ao longo dos anos.

A seguir, indicaremos algumas destas transformações de pensamento, de como Arte enquanto Componente Curricular está inserida nos PCN's e quais as propostas que formulamos para a rede de ensino alagoana.

\section{O Ensino da Arte na Educação Brasileira}

Antes de se constituir um componente curricular obrigatório, Arte percorreu um longo caminho histórico que vem desde a época da colonização, passando pelos ensinamentos dos jesuítas que perduraram até 1816, quando D. João VI trouxe a Missão Artística Francesa para o Brasil com o intuito de formar uma Escola de Arte, objetivo que esperou dez anos para começar a funcionar devido ao custo elevado.

O ensino de Arte sob os moldes da escola francesa, vinculada à apreensão artística da natureza, começa a ser questionado principalmente a partir de propostas vindas dos EUA e da Inglaterra, voltadas para a formação de desenhistas industriais.

O embate de escolas e pedagogias perdurou até os inícios de 1920, quando predominavam, aqui no Brasil, a cópia de quadros e o desenho geométrico. Nesse momento, a Arte passa a ser incluída no currículo escolar como atividade integrativa, apoiando o aprendizado de outras disciplinas, porém mantendo como eixo o desenho e seus exercícios de cópia. 
A Semana de Arte Moderna de 1922 trouxe não só um novo pensamento para as artes brasileiras como também para suas metodologias pedagógicas através da Arte-Educação, impulsionada com as ideias de livre expressão, de Mário de Andrade e Anita Malfatti, que acreditavam que a Arte tinha como finalidade principal permitir que a criança expressasse seus sentimentos, pois não era ensinada, mas expressada. Esse pensamento também irá influenciar o artista plástico Augusto Rodrigues que, em 1948, fundou a Escolinha de Arte no Brasil, onde era valorizada a capacidade criadora dos estudantes.

Ainda que este pensamento pedagógico circulasse pelos meios artísticos brasileiros, tais propostas não conseguiram romper os muros da escola. A dificuldade de diálogo entre escola e pedagogias da arte pode ser exemplificada quando, a partir dos anos de 1950, além de Desenho, passaram a fazer parte do currículo escolar as matérias Música, Canto Orfeônico e Trabalhos Manuais. Tal ampliação de matérias ligadas às linguagens artísticas ainda manteve o caráter e a metodologia do ensino escolar de então, baseado no que se convencionou chamar de Pedagogia Tradicional, concentrados na transmissão de conteúdos a serem reproduzidos pelosestudantes, sem preocupação com suas realidades sociais nem com suas diferenças individuais.

O ensino da Arte no Brasil continuou

[p.115]

vivendo sob um conflito de propostas e sistemas pedagógicos entre as décadas de 1950 e início de 1970, tendo, de um lado, a Escola Nova e a ênfase na livre expressão e na espontaneidade, e de outro, a Pedagogia Tecnicista, em que o aluno e o professor tinham um papel secundário, pois o sistema técnico de organização era tido como elemento principal. Neste pensamento pedagógico, os professores enfatizavam um saber construir reduzido dos aspectos técnicos e do uso diversificado de materiais, caracterizando pouco compromisso com o conhecimento da linguagem artística.

A Arte foi incluída no currículo escolar, em 1971, com o nome de Educação Artística, através da Lei de Diretrizes e Bases da Educação Nacional (5692/71), como atividade educativa e não como disciplina. Em 1988, a partir das discussões sobre a Nova Lei de Diretrizes e Bases, alguns grupos de educadores, convictos da importância de acesso escolar dos alunos da Educação Básica também à área de arte, posicionaram-se contrariamente a uma das versões da referida lei, que retirava a obrigatoriedade da área. A partir dos anos 1980, passam-se a discutir novas técnicas educacionais, ressaltando-se a influência dos estudos de Ana Mae Barbosa e sua proposta de Pedagogia Triangular para o ensino da Arte, composta pela contextualização histórica da Arte, pela apreciação artística ou seja, leitura da obra de arte, e pelo fazer artístico.

Com a LDB de 1996 (9.394/96), revogam-se as disposições anteriores e a Arte passa a ser considerada disciplina obrigatória na educação básica visando o desenvolvimento cultural dos alunos.

Neste sentido, Maria Heloísa Ferraz e Maria Fusari defendem que nas aulas de Arte devem ser trabalhados o mundo do educando, propiciando-Ihes contato com 
as obras de arte, desenvolvendo atividades a partir das quais o mesmo possa experimentar novas situações, podendo compreender e se apropriar mais facilmente do mundo cultural e estético. As autoras defendem também que compete ao professor um contínuo trabalho de verificação e acompanhamento em seus processos de elaborar, assimilar e expressar os novos conhecimentos de arte e de educação escolar dos aprendizes em Arte, ao longo do curso, e que a avaliação deve estar centrada em todo o processo de ensino e de aprendizagem.

Objetivos da Atual Legislação Educacional

Segundo o Art. 22 da LDBEN, a Educação Básica tem por finalidade desenvolver o educando, assegurar-Ihe a formação comum indispensável para o exercício da cidadania e fornecer-lhe meios para progredir no trabalho e em estudos posteriores.

No caso do Componente Curricular Arte, a LDBEN determina que a carga horaria anual será de quarenta horas por cada turma nos níveis fundamental e médio, podendo organizar-se classes, ou turmas, com alunos de séries distintas, com níveis equivalentes de adiantamento na matéria. A verificação do desempenho escolar deve ser realizada através de avaliação contínua e cumulativa da aprendizagem do aluno, com prevalência dos aspectos qualitativos sobre os quantitativos e dos resultados ao longo do período sobre os de eventuais provas finais.

As aprendizagens a serem garantidas consistem em:

- conhecer e compreender as diversas linguagens da arte (visuais, cênicas, musicais e dança);

- conhecer e compreender a produção artística como instrumento de aprendizagem, meio de comunicação e interação social;

- entender e identificar as diferentes funções da arte no contexto social;

[p.116]

- compreender arte nos aspectos histórico, cultural e social e sua influência nas mudanças sociais e os fatores que interferem na obra de arte;

- reconhecer a mídia como laboratório de arte no sentido de oferecer referência para experiências como desenho, pintura, gravura, no processo de criação;

- respeitar e valorizar a diversidade de manifestações artísticas locais e regionais;

- reconhecer a Arte como instrumento de socialização, comunicação, aproximação e humanização da pessoa;

- expressar e reproduzir experimentos plásticos, artísticos e folclóricos, valorizando as expressões da arte do povo brasileiro e produzir e reproduzir trabalhos de artes, utilizando diversos materiais gráficos e plásticos, sobre diferentes superfícies, identificando características e estilos. 
A pesar de que, atualmente, o ensino de Arte está voltado para as linguagens de Música, Dança, Teatro e Artes Visuais, somente em 2008 o ensino dos conteúdos da música passou a ser obrigatório, com a aprovação da Lei Federal 11.769.

\section{Os Referenciais Alagoanos}

Ainda que presente na história da educação brasileira desde as atividades pedagógicas desenvolvidas pelos jesuítas no tempo da colônia, a Arte ainda procura formas de inserção em nossos currículos, conforme expusemos acima.

As dificuldades referem-se principalmente à compreensão insuficiente da importância das artes em nossa vida cotidiana, à formação dos professores nem sempre desenvolvida a partir das recomendações dos PCN-Arte, à pequena carga horária destinada ao componente curricular e à ausência de espaços adequados para o desenvolvimento de atividades específicas das diversas linguagens artísticas.

No que se refere à importância do ensino da Arte, encontramo-nos, no momento, em uma situação paradoxal: a Educação Básica demanda professores com uma formação genérica e polivalente que o Ensino Superior, especializado, não supre.

O que fazer? Reafirmamos a necessidade da presença de professores especialistas e espaço curricular para as quatro linguagens, visto que cada uma se diferencia da outra em sua forma de operar sobre o mundo. Porém, por se tratar de iniciativa inviável dentro da atual estrutura educacional do país, a proposta que o professor de Arte trabalhe a partir da linguagem específica na qual realizou sua formação superior, desenvolvendo atividades que incluam, sempre que possível, as outras linguagens artísticas.

Outra questão a ser enfrentada se refere aos eixos de aprendizagem, baseados na pedagogia triangular presente nos PCN-Arte e em Ana Mae Barbosa: fazer, ler e contextualizar. Foi o caso do acento no fazer em época em que se pregava a livre expressão dos educandos e que disseminou uma visão de arte voltada somente à subjetividade, sem muita conexão com o mundo concreto. Atualmente, vivemos um período em que o acento recai em uma contextualização superficial, reduzindo as aulas de Arte ao acúmulo acrítico de informações, numa espécie de linha histórica da Arte, desprezando a construção e leitura de processos e objetos artísticos. Pouca importância se deu, historicamente, às atividades voltadas à leitura, à fruição e à apreciação da obra, o que procuramos sublinhar neste documento, preocupados que estamos com a recepção acrítica de objetos artísticos, principalmente àqueles produzidos pela indústria cultural.

[p.117]

4.6.3.1 Organização do Conhecimento Escolar de Arte

COMPONENTE CURRICULAR: ARTE - 6 ANO - FUNDAMENTAL

DIREITOS DE APREDIZAGEM 
- Valorização da arte como forma de pensamento.

- Uso das linguagens artísticas como ferramentas de leitura, contextualização e transformação de si e de sua comunidade.

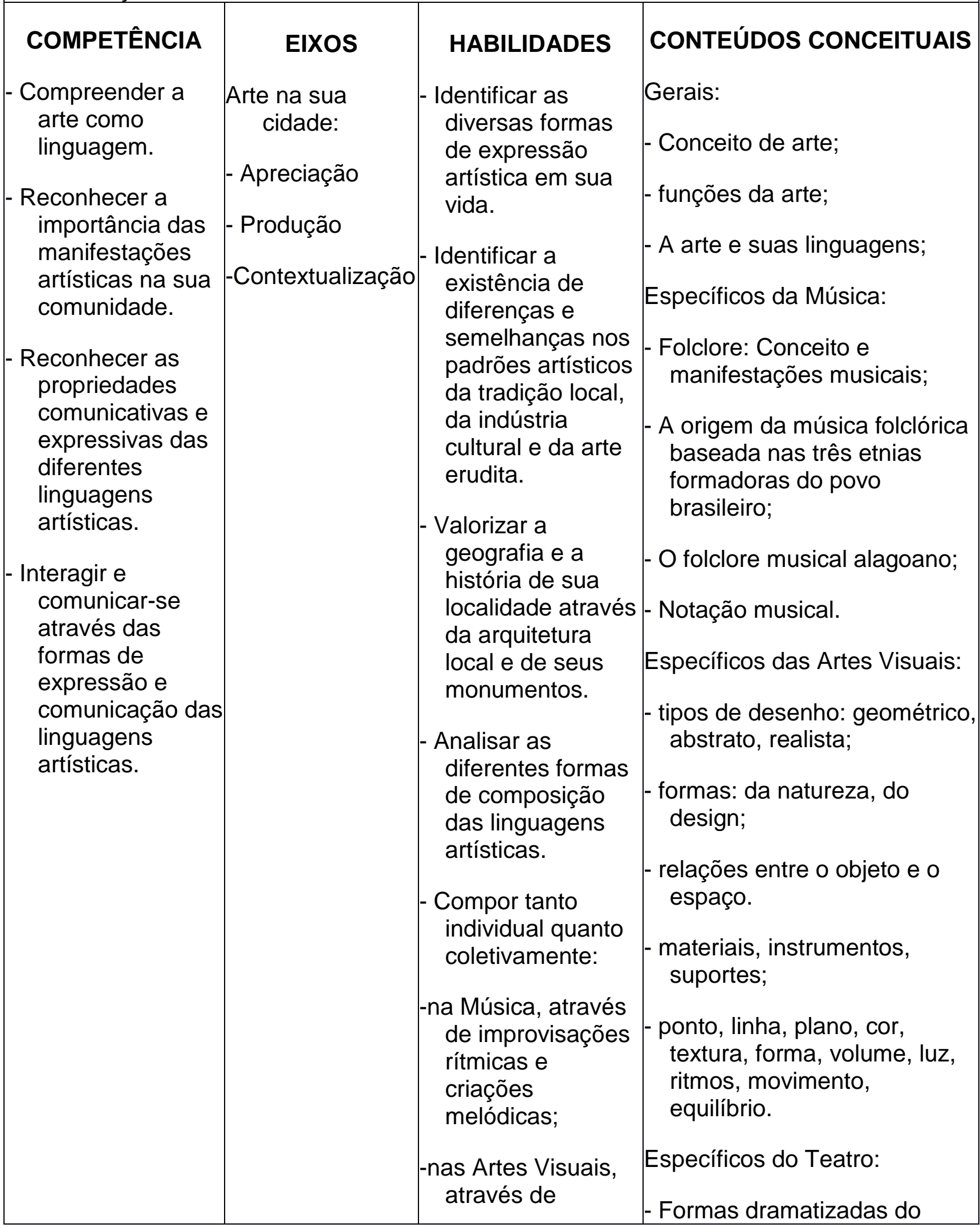




\begin{tabular}{|c|c|c|c|}
\hline & & \begin{tabular}{|l|} 
experimentações \\
com desenhos, \\
colagens, \\
pinturas, \\
fotografias e \\
produções \\
audiovisuais; \\
-no Teatro, através \\
de jogos teatrais e \\
improvisações \\
cênicas; \\
- na Dança, através \\
de improvisações \\
coreográficas e \\
gestuais.
\end{tabular} & $\begin{array}{l}\text { cotidiano: brincadeiras } \\
\text { infantis, contadores de } \\
\text { histórias, papéis sociais, } \\
\text { narrativas familiares; } \\
\text { manifestações tradicionais, } \\
\text { artistas populares de rua. } \\
\text { - gesto, sons, palavras, } \\
\text { movimentos coreográficos, } \\
\text { coro, elementos plásticos, } \\
\text { fábula. } \\
\text { - jogo teatral: espaço, } \\
\text { personagens e situação. } \\
\text { Específicos da Dança: } \\
\text { - origens: familiares, } \\
\text { comunitárias, de trabalho, } \\
\text { religiosas, profanas, da } \\
\text { indústria cultural; } \\
\text { - formas: individuais, de salão, } \\
\text { coletivas. } \\
\text { - gestos expressivos e } \\
\text { comunicativos, coreografias, } \\
\text { ritmo. }\end{array}$ \\
\hline
\end{tabular}

[p.118]

COMPONENTE CURRICULAR: ARTE - $7^{\circ}$ ANO - FUNDAMENTAL

DIREITOS DE APREDIZAGEM

\section{ATITUDES}

Abordagem e uso da arte como forma de pensar o mundo.

Uso das linguagens artísticas como ferramentas de leitura, contextualização e transformação da realidade.

\begin{tabular}{|c|c|c|c|}
\hline & & HABILIDADES & $\begin{array}{l}\text { CONTEÚDOS } \\
\text { CONCEITUAIS }\end{array}$ \\
\hline $\begin{array}{l}\text { Reconhecer as } \\
\text { contribuições } \\
\text { sociais e } \\
\text { culturais da arte } \\
\text { nos diversos } \\
\text { momentos da }\end{array}$ & $\begin{array}{l}\text { Arte em Alagoas: } \\
\text { - Apreciação; } \\
\text { - Produção; }\end{array}$ & $\begin{array}{l}\text { Distinguir os } \\
\text { fatores de } \\
\text { construção de } \\
\text { identidade e } \\
\text { seus reflexos no } \\
\text { estabelecimento }\end{array}$ & $\begin{array}{l}\text { Gerais: } \\
\text { - Arte Sacra. } \\
\text { - Literatura e História da Arte }\end{array}$ \\
\hline
\end{tabular}




\begin{tabular}{|c|c|c|c|}
\hline $\begin{array}{l}\text { história } \\
\text { alagoana. } \\
\text { - Valorizar a } \\
\text { diversidade } \\
\text { cultural na } \\
\text { formação da } \\
\text { identidade } \\
\text { alagoana a partir } \\
\text { das } \\
\text { contribuições de } \\
\text { suas etnias } \\
\text { formadoras: } \\
\text { indígenas, } \\
\text { africanas e } \\
\text { europeias. } \\
\text { - Interagir e } \\
\text { comunicar-se } \\
\text { através dos } \\
\text { elementos } \\
\text { expressivos } \\
\text { característicos } \\
\text { da tradição } \\
\text { artística } \\
\text { alagoana, da } \\
\text { indústria cultural } \\
\text { e da arte erudita, } \\
\text { e posicionar-se } \\
\text { criticamente } \\
\text { diante deles. }\end{array}$ & - Contextualização. & \begin{tabular}{|l} 
de diferenças \\
sociais. \\
- Analisar a função \\
das \\
manifestações \\
artísticas dentro \\
das etnias \\
formadoras. \\
- Utilizar de forma \\
crítica as formas \\
de diálogos \\
entre as etnias e \\
a decorrente \\
miscigenação. \\
- Reconhecer as \\
motivações e as \\
relações de \\
poder na \\
valorização de \\
determinadas \\
expressões \\
artísticas em \\
detrimento de \\
outras. \\
- Apreciar e \\
interpretar \\
imagens \\
artísticas ligadas \\
ao imatruturas dasíário \\
consticas para a \\
ideias emão defesa \\
cultural \\
alagoano; \\
- Identificar as \\
formas de \\
composição nas \\
manifestações \\
artísticas da \\
tradição \\
alagoana. \\
-
\end{tabular} & $\begin{array}{l}\text { em Alagoas. } \\
\text { - Manifestações dramático- } \\
\text { musicais alagoanas } \\
\text { (exemplos: Guerreiro, } \\
\text { Fandango, Pastoril, Boi, } \\
\text { Quadrilha Junina e } \\
\text { outras). } \\
\text { - Mestres populares } \\
\text { tradicionais e artistas } \\
\text { representativos nas } \\
\text { diversas linguagens } \\
\text { artísticas. } \\
\text { - A arte da tradição dos } \\
\text { brincantes. } \\
\text { Específicos da Música: } \\
\text { - manifestações musicais da } \\
\text { tradição popular alagoana } \\
\text { (exemplos: Coco, } \\
\text { - danças da tradição popular } \\
\text { alagoana (exemplos: } \\
\text { Coco, Maracatu e outras). } \\
\text { - Tearacatu, Repentistas, } \\
\text { Samba etc.); } \\
\text { - artespanaticos da Rato alagificos do Teatro: } \\
\text { (rendas, estatuário etc.); } \\
\text { - elementos da linguagem } \\
\text { musical. } \\
\text { Específicos das Artes Visuais: } \\
\text { - }\end{array}$ \\
\hline
\end{tabular}




\begin{tabular}{|l|l|l|}
\hline & $\begin{array}{l}\text { de um ponto de } \\
\text { vista. } \\
\text { Saber atuar em } \\
\text { processos de } \\
\text { criação, tanto } \\
\text { individuais como } \\
\text { coletivos. }\end{array}$ \\
\hline
\end{tabular}

[p.119]

COMPONENTE CURRICULAR: ARTE - 8ㅇ ANO - FUNDAMENTAL

DIREITOS DE APREDIZAGEM

\section{ATITUDES}

- Abordagem e uso da arte como forma de pensamento de e sobre o mundo;

- uso das linguagens artísticas como ferramentas de leitura, contextualização e possibilidades de transformação da realidade.

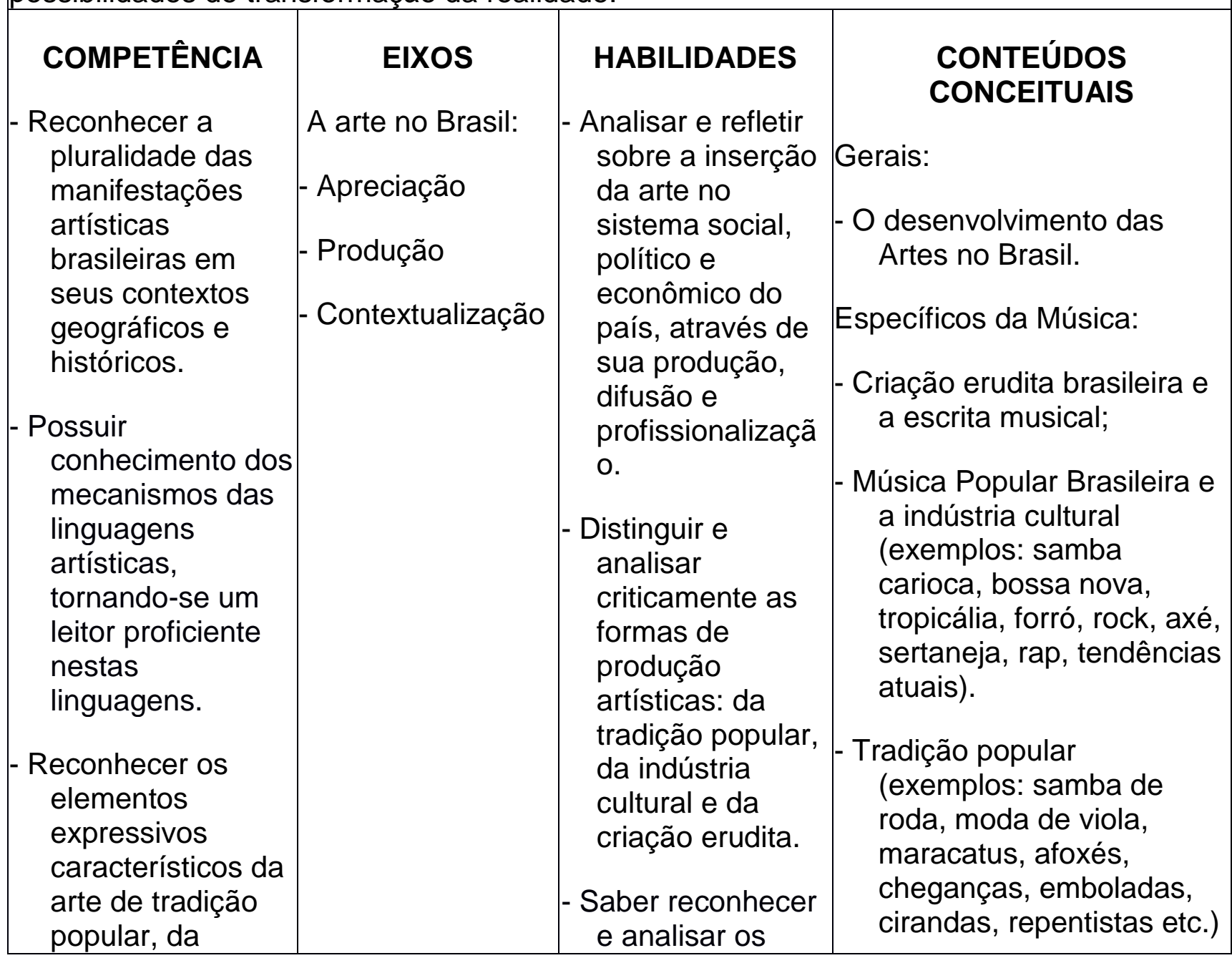




\begin{tabular}{|c|c|c|}
\hline $\begin{array}{l}\text { indústria cultural e } \\
\text { da arte erudita. } \\
\text { - interagir e } \\
\text { comunicar-se } \\
\text { através das } \\
\text { formas de } \\
\text { expressão e } \\
\text { comunicação das } \\
\text { linguagens } \\
\text { artísticas a partir } \\
\text { do eixo arte no } \\
\text { Brasil. }\end{array}$ & $\begin{array}{l}\text { processos de } \\
\text { construção de } \\
\text { sentido nas } \\
\text { diversas } \\
\text { linguagens. } \\
\text { - Distinguir os } \\
\text { elementos } \\
\text { originais da } \\
\text { tradição popular } \\
\text { presentes na } \\
\text { produção erudita } \\
\text { brasileira; } \\
\text { - Distinguir as } \\
\text { formas } \\
\text { expressivas } \\
\text { específicas das } \\
\text { etnias } \\
\text { formadoras do } \\
\text { povo brasileiro. } \\
\text { - Contextualizar os } \\
\text { estilos artísticos } \\
\text { estudados. } \\
\text { - Ler os gestos a } \\
\text { partir de } \\
\text { imagens. } \\
\text { - Expor } \\
\text { experimentos } \\
\text { artísticos. } \\
\text { - Criar coreografias } \\
\text { e interpretar } \\
\text { danças a partir } \\
\text { de ritmos } \\
\text { tradicionais } \\
\text { brasileiros. }\end{array}$ & $\begin{array}{l}\text { Específicos das Artes } \\
\text { Visuais: } \\
\text { - Arte barroca brasileira; } \\
\text { - Academicismo no século } \\
\text { XIX; } \\
\text { - Artes Visuais no século XX } \\
\text { (exemplos: Modernistas, } \\
\text { Concretos, Neoconcretos, } \\
\text { Abstratos, Pop-art e } \\
\text { contemporâneos); } \\
\text { - Artes gráficas no século XX; } \\
\text { - Produção audiovisual } \\
\text { brasileira: cinema, } \\
\text { televisão e produções } \\
\text { digitais. } \\
\text { Específicos do Teatro: } \\
\text { - Surgimento do Teatro } \\
\text { Brasileiro; } \\
\text { - Danças profanas. } \\
\text { - Circos populares; } \\
\text { - Etnocenologia (exemplos: } \\
\text { Escolas de Samba, Bois, } \\
\text { Maraciocatus, Cavalo } \\
\text { Marinho etc.) } \\
\text { - Surgimento da dança no } \\
\text { - }\end{array}$ \\
\hline
\end{tabular}

[p.120]

COMPONENTE CURRICULAR: ARTE - 9 ANO - FUNDAMENTAL 


\section{ATITUDES}

Abordagem e uso da arte como forma de pensamento de mundo e sobre o mundo;

- Uso das linguagens artísticas como formas de compreensão e contextualização da arte universal.

\begin{tabular}{|c|c|c|c|}
\hline \begin{tabular}{|l|} 
COMPETÉNCIA \\
- Contextualizar as \\
artes na história da \\
humanidade, \\
reconhecendo \\
suas \\
manifestações em \\
diferentes culturas \\
e civilizações. \\
- Contextualizar \\
geograficamente \\
as manifestações \\
artísticas, \\
distinguindo as \\
formas \\
expressivas \\
específicas de \\
diferentes \\
sociedades. \\
- Reconhecer os \\
elementos \\
expressivos \\
característicos de \\
diferentes estilos, \\
escolas e \\
movimentos \\
artísticos.
\end{tabular} & $\begin{array}{l}\text { EIXOS } \\
\text { A arte no mundo: } \\
\text { - Apreciação } \\
\text { - Produção } \\
\text { - Contextualização }\end{array}$ & $\begin{array}{l}\text { HABILIDADES } \\
\text { - Distinguir as } \\
\text { manifestações } \\
\text { artísticas } \\
\text { tradicionais e as } \\
\text { maneiras de sua } \\
\text { inserção nas } \\
\text { culturas } \\
\text { "oficiais". } \\
\text { - Contextualizar os } \\
\text { estilos artísticos } \\
\text { estudados. } \\
\text { - Estabelecer } \\
\text { conexões e } \\
\text { aproximações } \\
\text { entre diferentes } \\
\text { manifestações } \\
\text { artísticas; } \\
\text { - Reconhecer as } \\
\text { formas de } \\
\text { composição de } \\
\text { diferentes } \\
\text { civilizações e } \\
\text { sociedades; } \\
\text { - Ler a arte } \\
\text { contemporânea. } \\
\text { - Conhecer e } \\
\text { utilizar as } \\
\text { possibilidades } \\
\text { de construção } \\
\text { de sentidos das } \\
\text { diferentes } \\
\text { linguagens. }\end{array}$ & $\begin{array}{l}\quad \text { CONTEÚDOS } \\
\text { CONCEITUAIS } \\
\text { Gerais: } \\
\text { - História da Arte no } \\
\text { Ocidente; } \\
\text { - Arte Africana; } \\
\text { - Arte no Oriente. } \\
\text { Específicos da Música: } \\
\text { - Princípios da música } \\
\text { erudita no ocidente; } \\
\text { - Música sacra e música } \\
\text { profana; } \\
\text { - Músicas do Oriente e da } \\
\text { África; } \\
\text { - Música contemporânea. } \\
\text { Específicos das Artes } \\
\text { Visuais: } \\
\text { - Visualidades orientais e } \\
\text { africanas; } \\
\text { - Tendências } \\
\text { contemporâneas. } \\
\text { Específicos do Teatro: } \\
\text { - Surgimento do Teatro } \\
\text { ocidental; } \\
\text { - Teatros orientais (Japão, } \\
\text { China, Bali, Índia); } \\
\text { - Etnocenologia; } \\
\end{array}$ \\
\hline
\end{tabular}




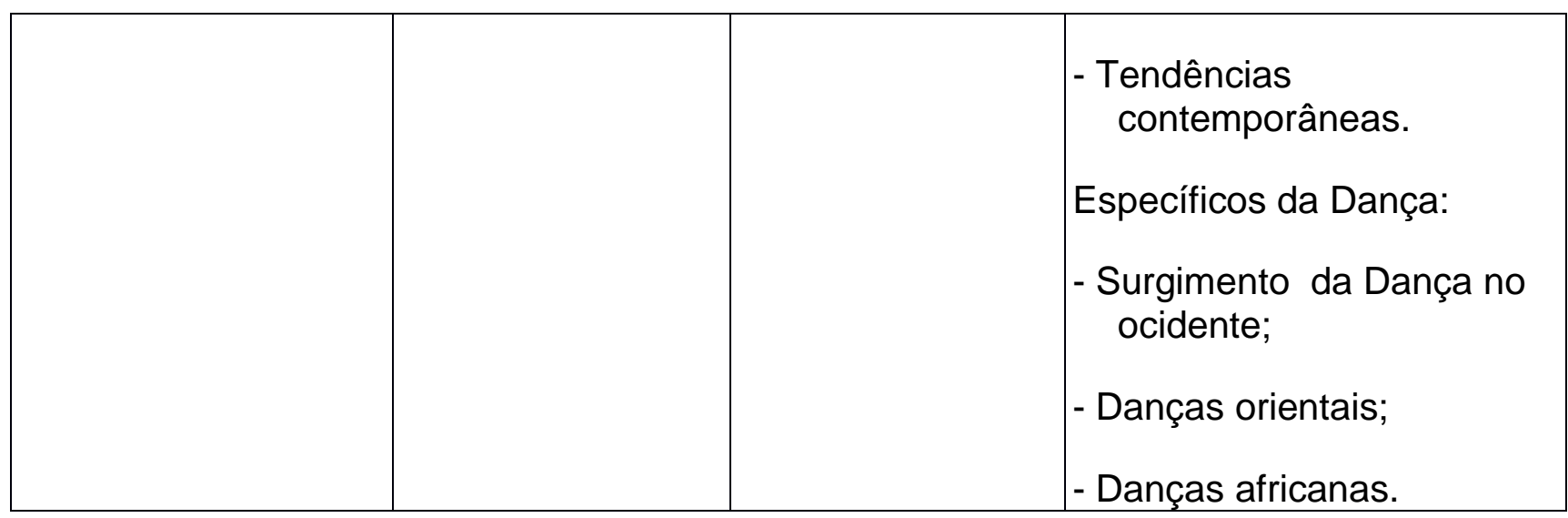

[p.121]

COMPONENTE CURRICULAR: ARTE - 1 ANO - MÉDIO

DIREITOS DE APREDIZAGEM

\section{ATITUDES}

- Uso das formas de pensamento artístico para o conhecimento de si próprio e do outro.

\begin{tabular}{|c|c|c|c|}
\hline $\begin{array}{l}\text { COMPETÊNCIA } \\
\text { Compreender a } \\
\text { arte como } \\
\text { expressão } \\
\text { subjetiva. } \\
\text { Conhecer } \\
\text { conceitos } \\
\text { filosóficos } \\
\text { relativos à } \\
\text { arte, à } \\
\text { estética, ao } \\
\text { belo e ao } \\
\text { grotesco. } \\
\text { Saber ler e } \\
\text { utilizar os } \\
\text { elementos } \\
\text { expressivos } \\
\text { presentes em } \\
\text { obras de arte. }\end{array}$ & \begin{tabular}{|l|}
\multicolumn{1}{|c|}{ EIXOS } \\
O sujeito e a \\
obra de arte \\
(dimensão \\
subjetiva) \\
- Apreciação \\
- Produção \\
- \\
Contextualização
\end{tabular} & $\begin{array}{l}\text { HABILIDADES } \\
\text { - Identificar os aspectos } \\
\text { psicológicos e metafísicos } \\
\text { em processos de criação } \\
\text { artística. } \\
\text {-Reconhecer as relações } \\
\text { intertextuais subjetivas e } \\
\text { seus efeitos na construção } \\
\text { de sentido. } \\
\text { - Estabelecer conexões entre } \\
\text { a vontade de expressão } \\
\text { humana e as formas } \\
\text { estéticas que estas } \\
\text { assumem. } \\
\text { - Confrontar obras artísticas } \\
\text { de diferentes linguagens e } \\
\text { estilos com o propósito de } \\
\text { analisar sua função } \\
\text { sociolingüística. } \\
\text { - Saber atuar em processos } \\
\text { de criação, tanto } \\
\text { individuais como coletivos: }\end{array}$ & $\begin{array}{l}\text { CONTEÚDOS } \\
\text { CONCEITUAIS } \\
\text { Gerais: } \\
\text { - Arte na Filosofia Grega } \\
\text { Clássica; } \\
\text { - Arte no pensamento } \\
\text { oriental; } \\
\text { - Arte e o pensamento } \\
\text { medieval; } \\
\text { - Arte e lluminismo; } \\
\text { - As vanguardas artísticas } \\
\text { do início do século } \\
\text { XX; } \\
\text { - Arte na pós } \\
\text { modernidade. } \\
\text { Específicos da Música: } \\
\text { - música sacra; } \\
\text { - música no Romantismo; }\end{array}$ \\
\hline
\end{tabular}




\begin{tabular}{|c|c|c|c|}
\hline & & $\begin{array}{l}\text {-- na Música: improvisações a } \\
\text { partir de temáticas } \\
\text { subjetivas; criações } \\
\text { musicais através de mídias } \\
\text { digitais. } \\
\text {-- nas Artes Visuais: } \\
\text { experimentações plásticas } \\
\text { a partir da expressão } \\
\text { subjetiva dos alunos; } \\
\text { criações audiovisuais. } \\
\text {-- no Teatro: jogo teatral } \\
\text { (criação e improvisação de } \\
\text { cenas dramáticas). } \\
\text {-- na Dança: improvisações } \\
\text { coreográficas a partir da } \\
\text { subjetividade dos alunos. }\end{array}$ & $\begin{array}{l}\text { - improvisação no jazz e } \\
\text { na música } \\
\text { instrumental } \\
\text { contemporânea. } \\
\text { Específicos das Artes } \\
\text { Visuais: } \\
\text { - arte sacra; } \\
\text { - Romantismo: pintura e } \\
\text { escultura. } \\
\text { - Impressionismo, } \\
\text { Expressionismo, } \\
\text { Cubismo e } \\
\text { Surrealismo; } \\
\text { Específicos do Teatro: } \\
\text { - O Drama burguês } \\
\text { (conceito e formas). } \\
\text { Específicos da Dança: } \\
\text { - Danca modernista }\end{array}$ \\
\hline
\end{tabular}

[p.122]

\section{COMPONENTE CURRICULAR: ARTE - 2 ANO - MÉDIO}

\section{DIREITOS DE APREDIZAGEM}

\section{ATITUDES}

Abordagem e uso da arte como forma de comunicação e transformação do mundo.

\begin{tabular}{|c|c|c|c|}
\hline $\begin{array}{l}\text { COMPETÊNCIA } \\
\text { Reconhecer os } \\
\text { elementos } \\
\text { comunicacionais e } \\
\text { objetivos das } \\
\text { linguagens } \\
\text { artísticas. } \\
\text { Conhecer as } \\
\text { reflexões da } \\
\text { Sociologia sobre a }\end{array}$ & $\begin{array}{l}\quad \text { EIXOS } \\
\text { A Arte e } \\
\text { sociedade. } \\
\text { - Apreciação } \\
\text { - Produção } \\
\text { - Contextualização }\end{array}$ & $\begin{array}{l}\text { HABILIDADES } \\
\text { - Reconhecer as } \\
\text { intenções } \\
\text { pedagógicas da } \\
\text { arte. } \\
\text { - Identificar o } \\
\text { sentido das } \\
\text { diversas } \\
\text { linguagens } \\
\text { artísticas a }\end{array}$ & $\begin{array}{l}\text { CONTEÚDOS } \\
\text { CONCEITUAIS } \\
\text { Gerais: } \\
\text { - Arte e Política; } \\
\text { - Arte como mercadoria; } \\
\text { - Arte como instrumento de } \\
\text { ação política. }\end{array}$ \\
\hline
\end{tabular}




\begin{tabular}{|c|c|c|}
\hline $\begin{array}{l}\text { arte. } \\
\text { - Compreender o } \\
\text { sentido das } \\
\text { diversas } \\
\text { linguagens } \\
\text { artísticas no } \\
\text { contexto social, } \\
\text { identificando na } \\
\text { produção artística } \\
\text { a crítica às formas } \\
\text { de organização } \\
\text { desigual da } \\
\text { sociedade } \\
\text { contemporânea. } \\
\text { - Conceber a } \\
\text { realidade como } \\
\text { construção } \\
\text { sóciossimbólica. } \\
\text { - Saber ler, } \\
\text { contextualizar e } \\
\text { utilizar os } \\
\text { elementos } \\
\text { comunicacionais } \\
\text { presentes em } \\
\text { obras } \\
\text { politicamente } \\
\text { comprometidas } \\
\text { com mudanças } \\
\text { sociais. }\end{array}$ & $\begin{array}{l}\text { partir de seus } \\
\text { contextos } \\
\text { sociais; } \\
\text { - Identificar na arte } \\
\text { seus aspectos } \\
\text { históricos, } \\
\text { culturais e } \\
\text { sociais. } \\
\text { - Refletir sobre a } \\
\text { importância da } \\
\text { obra de arte na } \\
\text { dinâmica social. } \\
\text { - Dialogar com os } \\
\text { diferentes tipos } \\
\text { e gêneros } \\
\text { textuais, digitais } \\
\text { e impressos, } \\
\text { que circulam em } \\
\text { diversos } \\
\text { contextos } \\
\text { sociais. }\end{array}$ & $\begin{array}{l}\text { Específicos da Música: } \\
\text { - Música na cidade; } \\
\text { - A Canção brasileira de } \\
\text { protesto nas décadas de } \\
1960 \text { e 70; } \\
\text { - Reagge, Rap e outras } \\
\text { músicas de protesto } \\
\text { político-social. } \\
\text { Específicos das Artes } \\
\text { Visuais: } \\
\text { - Arquitetura e urbanismo: } \\
\text { edifícios públicos, praças } \\
\text { e ruas; } \\
\text { - Arte em espaços públicos; } \\
\text { - Mercado das artes } \\
\text { plásticas. } \\
\text { Específicos do Teatro: } \\
\text { - Corpo com agente de } \\
\text { transformação social. } \\
\text { opressão social; } \\
\text { - Teatro Grego e a polis; } \\
\text { - Teatro do Oprimido, de } \\
\text { Augusto Boal. } \\
\text { - Teatro épico de Bertolt } \\
\text { Brecht; }\end{array}$ \\
\hline
\end{tabular}

[p.123] 


\section{ATITUDES}

Percepção das produções artísticas contemporâneas como formas de expressão e comunicação entre os homens.

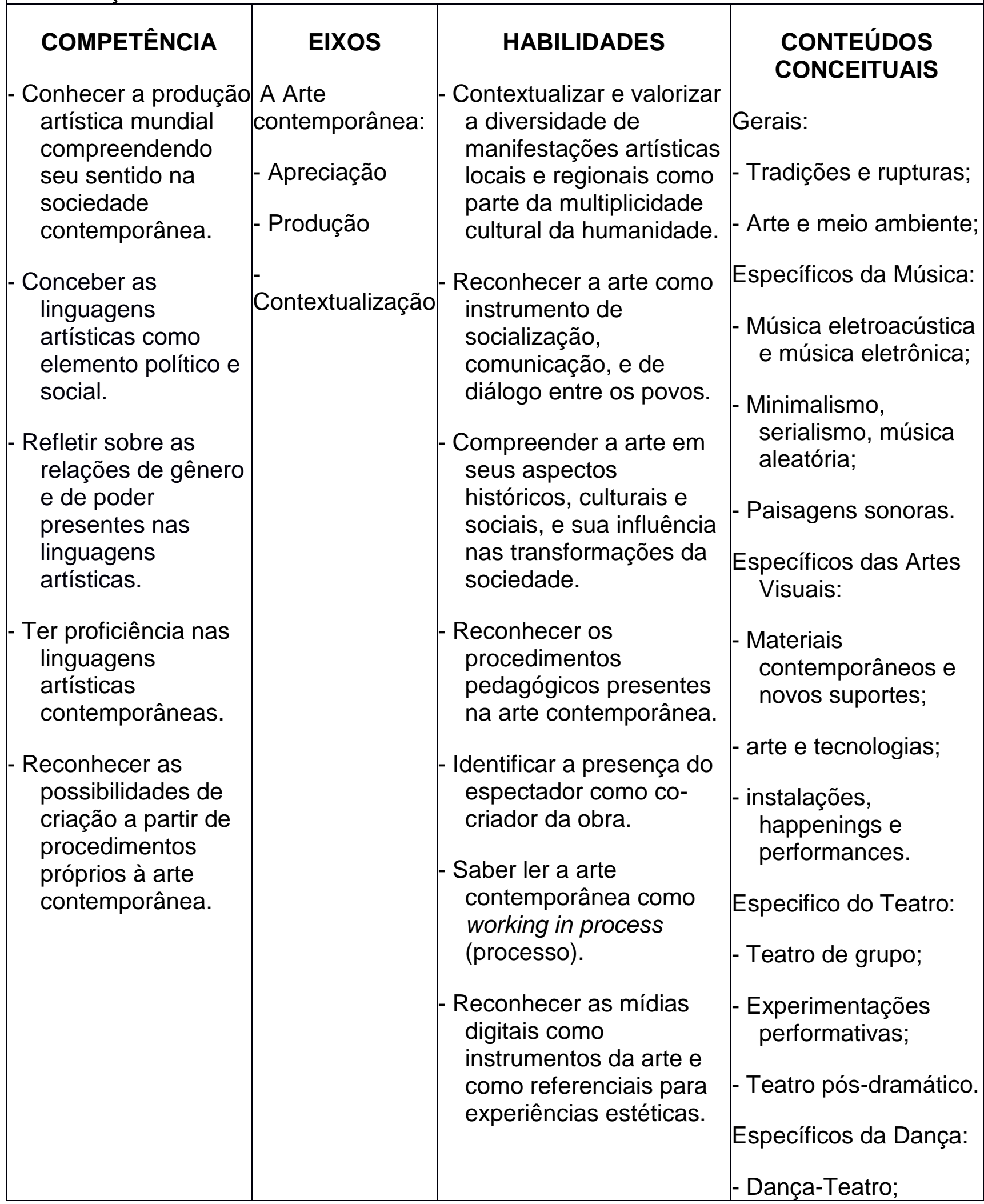




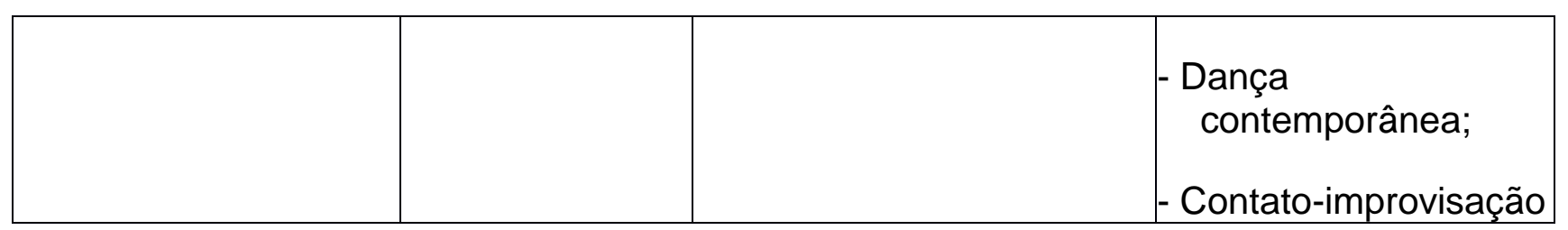

Capítulo 5 - Orientações Didático-metodológicas

p.173-175.

O Componente curricular Arte possui uma característica muito singular na sua concepção conceitual, pois abrange quatro linguagens artísticas que possuem conteúdos próprios e formações acadêmicas distintas. Como dissemos anteriormente, a partir dos PCN-Arte, que apontam para a necessidade do ensino específico de cada uma das linguagens artísticas, as universidades brasileiras extinguiram a antiga formação polivalente em Educação Artística, criando os cursos de Música, Teatro, Dança e Artes Visuais. No Referencial Curricular de Alagoas sugerimos que, mesmo considerando as competências comuns às quatro linguagens artísticas, cabe ao professor proporcionar o desenvolvimento das habilidades dos alunos utilizando principalmente os conteúdos próprios pertinentes à sua habilitação acadêmica.

Para uma melhor compreensão terminológica sempre que Arte vier iniciada com letra maiúscula, a referência é ao Componente Curricular; quando iniciada por minúscula, a referência é para a arte como expressão humana, abrangendo suas diversas formas de linguagem.

Outro aspecto desta proposta se refere aos eixos de aprendizagem, baseados na influência dos estudos de Ana Mae Barbosa e sua proposta de Pedagogia Triangular para o ensino da Arte, composta pela contextualiza-

$$
\text { [p.174] }
$$

ção histórica das artes, pela apreciação (leitura de processos e obras de arte) e pelo fazer artístico. Dentro desta proposta, indicamos operadores compatíveis com a estrutura seriada do ensino, sem, no entanto, ficarmos reféns de uma visão cronológica da arte em que, ou aparente uma (equivocada) evolução, ou reduza tudo a estilos, escolas e movimento. Com isto, não estamos negando a necessidade de reflexões pertinentes à História da Arte, mas incorporando-as a eixos geográficos e filosóficos.

Assim, no Ensino Fundamental, os eixos privilegiam a construção do conhecimento através de operadores espaciais, organizando o ensino a partir do contato direto do aluno com processos e objetos artísticos de seu local de moradia em direção às produções universais. Neste sentido, a referência para os alunos do 6 o ano é a arte produzida em sua comunidade e em sua cidade; para os alunos do $7^{\circ}$ ano, a arte produzida no Estado de Alagoas, para os alunos do $8^{\circ}$ ano, a arte produzida no país, e, finalmente, para os alunos do $9^{\circ}$ ano, a arte universal.

Os eixos de aprendizagem para o Ensino Médio baseiam-se em possíveis diálogos com as disciplinas Filosofia e Sociologia, com o objetivo de favorecer 0 
desenvolvimento, pelos alunos, da capacidade de refletir para além dos objetos artísticos, relacionando-os aos processos de criação e de difusão. Desta forma, a proposta de estudo, para os alunos do 1ำ ano, é o próprio sujeito criador, isto é, a dimensão subjetiva e expressiva do ato artístico, que envolve os aspectos psicológicos e filosóficos da criação e apreciação artística. Para os alunos do $2^{\circ}$ ano, a questão é a sociedade na qual a produção se insere, isto é, a dimensão objetiva e comunicativa do ato artístico, envolvendo os aspectos políticos e sociológicos em que esta produção está inserida. E, finalmente, para os alunos do 3ํano, a questão é a diversidade e a pluralidade das expressões artísticas contemporâneas, gerando possibilidades infinitas de diálogos entre formas de produção, agregando em seu aprendizado as dimensões multiculturais e antropológicas da arte.

Coerente com esses eixos de ensino e aprendizagem, indicamos como abordagem didático-metodológica a pedagogia triangular presente nos PCN-Arte e em Ana Mae Barbosa. A articulação das três ações (fazer, apreciar e contextualizar) é primordial para que a proposta pedagógica se concretize de forma adequada. Privilegiar uma em detrimento das demais pode gerar equívocos já cometidos no processo histórico e para os quais já chamamos a atenção anteriormente.

Enfatizamos aqui um princípio norteador explicitado no Quadro do Componente Curricular como atitude que os educandos devem desenvolver ao longo de sua formação educativa: a percepção da arte como forma de conhecimento do e de pensamento sobre o mundo que se diferencia dos conhecimentos filosóficos e científicos. As linguagens artísticas, assim como toda linguagem, possibilitam formas diferenciadas de leitura e de ação no mundo e, devido a sua presença desde a vida cotidiana dos alunos até às grandes realizações culturais da humanidade, deve ter sua importância reconhecida e, principalmente, destacada nos currículos escolares.

O reconhecimento da importância do ensino da Arte se verifica na organização do tempo e do espaço dentro das escolas e na criação de espaços específicos de aprendizagem. Indicamos que o professor de Arte trabalhe a partir da linguagem específica na qual realizou sua formação superior, procurando desenvolver atividades que incluam as demais linguagens artísticas. Essa proposta se reflete no Quadro do Componente

$$
\text { [p.175] }
$$

Curricular nas colunas dedicadas às habilidades e aos conteúdos conceituais, através de indicações gerais, que devem ser trabalhadas independente da formação do professor, e específicas dentro de cada uma das linguagens artísticas.

O ajuste nestas orientações depende da formação de cada professor, das necessidades dos alunos e das condições materiais encontradas na escola. Porém, sugerimos alguns encaminhamentos para a prática na sala de aula. Por exemplo, no sexto ano do Ensino Fundamental, o professor pode propor aos alunos, através de projetos pedagógicos, sequências didáticas ou atividades permanentes que façam um levantamento dos objetos artísticos presentes em sua casa. Neste levantamento se evidenciará qual é a compreensão de arte para cada um, compreensão que pode motivar atividades de reflexão sobre o que é arte e suas implicações na vida das 
pessoas, a origem de algumas expressões artísticas, a qualificação social do objeto artístico decorrente do meio de comunicação utilizado.

O objeto artístico (ou sua reprodução) levado à sala de aula pode passar por um processo de leitura destacando-se seus elementos constitutivos, os materiais utilizados em sua produção e a composição. Pode-se, em seguida, fazer-se a proposição de uma produção aos alunos, utilizando algum dos elementos levantados no estudo, seja os de contextualização histórico-social, sejam os materiais, os elementos ou a formas de composição. Uma possibilidade, após a produção, é a retomada destes objetos como modelos a serem apreciados e contextualizados a partir de sua origem. A sequência sugerida - contextualização, leitura e produção pode ser refeita de acordo com as necessidades e objetivos propostos.

O levantamento desses objetos de arte pode colocar em questão também as diferenças das linguagens artísticas, servindo como referência para especificar a linguagem na qual o professor é formado. Em se tratando de artes visuais, podemse estudar não somente possíveis quadros, reproduções, estatuetas, mas também as fotografias familiares, as cores utilizadas nas paredes e nos móveis, a composição dos ambientes, etc. No caso de música, pode pesquisar as produções da indústria cultural e, principalmente, as músicas das crianças, as tradicionais da família e da comunidade, as cantigas aprendidas com os pais e avós, etc. No caso de dança, pode trabalhar sobre as brincadeiras infantis de roda, as manifestações características da comunidade, as expressões advindas da indústria cultural, etc. $\mathrm{E}$ quando a situação é o trabalho com teatro, igualmente, pode ter como base de estudo as histórias familiares, as formas de narrativas orais e as brincadeiras dramáticas.

Enfim, o professor de Arte deverá buscar os conteúdos pertinentes à sua linguagem específica que contribuem para o desenvolvimento das habilidades e competências do componente curricular em suas atividades permanentes, nos projetos e sequencias didáticas.

\section{REFERÊNCIAS}

ALAGOAS. Constituição: Estado de Alagoas: Unidade Federativa do Brasil.: Maceió: Serviços Gráficos de Alagoas- outubro de 1989.

BARBOSA, Ana Mae. Arte-Educação: conflitos/acertos. São Paulo: Max Limonad, 1985.

Arte-Educação no Brasil. São Paulo: Perspectiva, (7ª ed.) 2012. Teoria e prática da Educação Artística. São Paulo: Cultrix, 1990.

BRASIL. Lei de Diretrizes e Bases da Educação Nacional. Brasília: MEC, 1996.

BRASIL Parâmetros Curriculares Nacionais. (1aa a $4^{a}$ série) Secretaria de Educação Fundamental - Brasília: MEC/ SEF, 1998

Parâmetros Curriculares Nacionais. (5 $5^{\underline{a}}$ a $8^{\underline{a}}$ série) Secretaria de

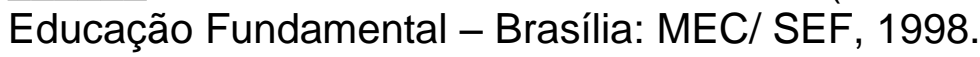


Parâmetros Curriculares Nacionais-Arte /Secretaria de Educação Fundamental - Brasília. MEC, $1997 .$.

. Parâmetros Curriculares Nacionais (Ensino Médio)/Secretaria de Educação Média e Tecnológica - Brasília. MEC, 2002.

FERRAZ, M. Heloísa C.; FUSARI, Maria F. de Rezende. Metodologia do Ensino da Arte. São Paulo: Cortez, 1993. 